\title{
LEITORES ANGOLANOS, VARIADAS LEITURAS: UM OLHAR SOBRE A LITERATURA DE ANGOLA NO PÓS- INDEPENDÊNCIA
}

\author{
Dissertação apresentada ao Programa de \\ Pós-Graduação em Estudos Comparados de \\ Literaturas de Língua Portuguesa do Departamento \\ de Letras Clássicas e Vernáculas da Faculdade de \\ Filosofia, Letras e Ciências Humanas da \\ Universidade de São Paulo para obtenção do título \\ de Mestre em Letras \\ Área de Concentração: Estudos Comparados de \\ Literaturas de Língua Portuguesa \\ Orientadora: Prof ${ }^{a}$ Dra. Tania Celestino de Macêdo
}

São Paulo

2017 


\section{FOLHA DE APROVAÇÃO}

\section{Ligia Helena Micas}

Leitores angolanos, variadas leituras: um olhar sobre a literatura de Angola no pósindependência

Dissertação apresentada à Faculdade de Filosofia, Letras e Ciências Humanas da Universidade de São Paulo como requisito à obtenção do título de Mestre em Letras.

Aprovado em:

Banca Examinadora

Prof ${ }^{a}$ Dra. Tania Celestino de Macêdo

Instituição: FFLCH - USP

Julgamento:

Assinatura:

$\operatorname{Prof}^{\mathrm{o}}$ Dr.

Instituição:

Julgamento:

Assinatura:

Prof $^{\circ}$ Dr.

Instituição:

Julgamento:

Assinatura: 
A quem partiu, a quem chegou. Ao meu pai, Manuel. Ao meu filho, Ravi.

Este trabalho tem um pouco do que sou.

E o que sou tem muito de vocês. 


\section{Agradecimentos}

Uma pesquisa acadêmica me parece daqueles caminhos em que, na vida, percorremos na mais acompanhada solidão. Ao mesmo tempo em que as principais ações são solitárias - a leitura, a investigação, a escrita, as angústias em meio à madrugada -, são muitos os gestos de acolhida e as trocas realizadas.

Todos os que cruzam nosso caminho nesse período em que vivemos uma espécie de suspensão acabam por ser importantes, pois atuam mesmo que indiretamente para que cada um dos nossos passos conflua para a dissertação. Todos parecem participar de um delicado balé que nos conduz na direção almejada.

Mas há aquelas pessoas sem as quais o trabalho de fato seria impossível. Delas guardarei cada olhar que permitiu que o meu se ampliasse para que pudesse materializar este trabalho. A elas serei sempre profundamente grata:

Aos meus interlocutores angolanos ou que possuem estreita ligação com esta incrível nação. Escritores, poetas, intelectuais, leitores, estudiosos, habitantes, sonhadores. Muitos nomes que hoje eu troco pelo de amigos. Que alegria estabelecer com vocês essa ponte entre um lado e outro do Atlântico.

Aos amigos com quem dividi essa mesma estrada larga, em que tanto cabe, que são os corredores da USP: meus queridos Estefânia, Luiz e Diego, foi muito mais leve porque com vocês foi compartilhado. Adriana, Marcelo: os intercâmbios desde a graduação seguem profícuos e, mais que úteis, aquecem o coração.

Aos amigos de toda a jornada que, com múltiplos gestos - que escutam, trocam, traduzem, incentivam, cuidam do filho, emprestam livros, devolvem livros ou perguntam "como está o mestrado?" -, fizeram este trabalho junto comigo: Simone, Tiago, Luiz Henrique, Flaviana, Sheila, Diane, minha irmã Carla, Helder, Betinha, Cristina e Gabi.

Aos gentis funcionários da FFLCH e aos mestres que muitas vezes não imaginam as profundas marcas que nos deixam: aos tantos professores da graduação, verdadeiros semeadores de vontades; Rita Chaves e Mário Lugarinho, pelas aulas da pós, espaços intensos de debate, e leitura cuidadosa do trabalho; João Luís Ceccantini, pelas contribuições; e Nelson Shapochinik, pela palavra precisa no momento certeiro.

À minha orientadora, Tania Macêdo, tão generosa no partilhar, responsável por tantos alunos que se apaixonaram irremediavelmente pela literatura angolana. Em meio aos diversos perfis de orientadores, obrigada por ser aquela que caminha ao nosso lado e respeita nossas descobertas, como se também as tivesse vendo pela primeira vez. 
Ao Guilherme, minha tempestade solar particular, meu companheiro, parceiro nas coisas mais preciosas desta vida. Tão grata por ser um grande entusiasta deste trabalho e da minha capacidade em concretizá-lo. E pelas trocas e cuidados que viabilizaram sua execução.

Ao pequeno Ravi, que com seu olhar curioso me lembrou nos momentos mais difíceis desta pesquisa o quanto descobrir é bonito, que com suas mãos arteiras desenterrou de minha biblioteca livros que eu já dava por esquecidos e que me foram fundamentais. Que bom, filho, te ter esquentando meu colo nas derradeiras leituras para este trabalho.

À avó do Ravi, minha mãe Maria Eugênia, que passou a vida me acalentando e hoje, ao ninar meu filho, fez mais que embalar este trabalho. 


\section{Resumo}

MICAS, L. H. Leitores angolanos, variadas leituras: um olhar sobre a literatura de Angola no pós-independência. 2017.172 f. Dissertação (Mestrado) - Faculdade de Filosofia, Letras e Ciências Humanas, Universidade de São Paulo, São Paulo, 2017.

A literatura desempenhou um relevante papel nos anos em torno da independência de Angola, conquistada em 1975, convocada que foi a participar dos contornos que redesenharam a nação. O governo que assumiu o país, em cujos quadros figuravam muitos dos poetas e escritores que lutaram pela libertação de Angola, desenvolveu uma série de ações para uma maior difusão do livro e da literatura. Este trabalho se debruça sobre o período entre 1975 e 1991, quando o Estado centralizou essas ações de apoio à leitura, propondo-se a entender como foi construído esse projeto e, sobretudo, como ele ecoou nos leitores de então, reconhecendo que o público é parte integrante e fundamental de um sistema literário. Para tanto, examinamos primeiramente duas instituições em muito responsáveis pelo que se publicou no país - a União dos Escritores Angolanos e o Instituto Nacional do Livro e do Disco -, a partir de depoimentos dos sujeitos que lideraram essas organizações e da análise do material produzido. Posteriormente trabalhamos com as memórias de quatro entrevistados, buscando reconstituir suas trajetórias de leitores e compreender seus diálogos com este projeto literário levado a cabo após a independência. Na chave da história da leitura e entendendo a literatura como sistema, esta dissertação deu voz a um segmento comumente silenciado e mostrou como são multifacetados os olhares em torno do projeto angolano.

Palavras-chave: literatura angolana, União dos Escritores Angolanos, Inald, leitura, leitor. 


\begin{abstract}
MICAS, L. H. Angolan readers, assorted readings: a look at Angola literature in post-independence. 2017. 172 f. Dissertation (Master's degree) - Faculdade de Filosofia, Letras e Ciências Humanas, Universidade de São Paulo, São Paulo, 2017.

The literature played a very relevant role in the Angolan Independence years, conquered in 1975. It was called to take part of the doings which helped to redesign the nation. The government which assumed the country, whose pictures figured many poets and writers who fought for Angola freedom, developed a variety of actions for a wider diffusion of the book and literature. This work is based between 1975 and 1991, when the Estate centralized these achievements supporting literature, proposing to understand how this project was built and, however, how the readers understood it, recognizing that the public plays a fundamental role in the Literary system. Because of that we first examined two institutions which were very important for the material the country published: The Union of Angolan Writers and The National Institute of the book and the record, from the testimony of the people who led these organizations and the analysis of the produced material. Later we worked with the reports of four interviewees looking for reconstituting their trajectories as readers and understanding their dialogues with this literary project carried out after independence. In the key of reading history and understanding the literature as a system, this writing gave voice to a commonly muted segment and showed how all-round looks are around the Angolan project.
\end{abstract}

Key-Words: Angolan literature, The Union of Angolan writers, Inald, reading, reader. 


\section{SUMÁRIO}

\section{CONSIDERAÇÕES INICIAIS............................................................................10}

1 - LIVROS, LEITURA, LEITORES: APROXIMAÇÕES TEÓRICAS.............16

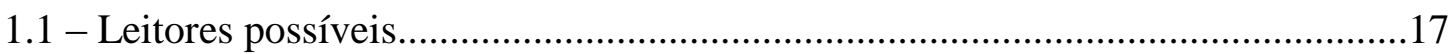

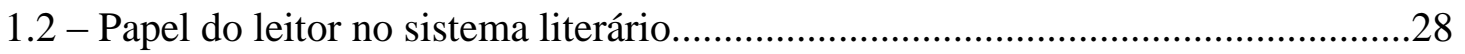

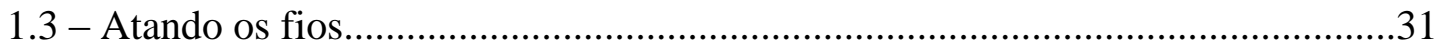

2 - ANGOLA: INTERLÚDIO LITERÁRIO...........................................................34

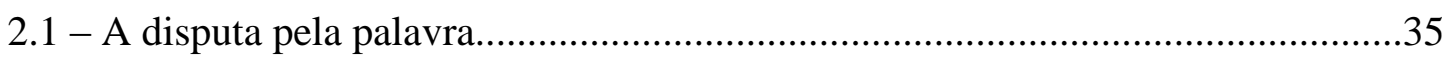

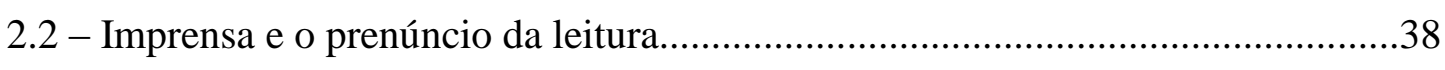

2.3 - Publicações Imbondeiro: o livro em Angola......................................................40

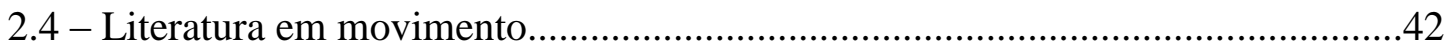

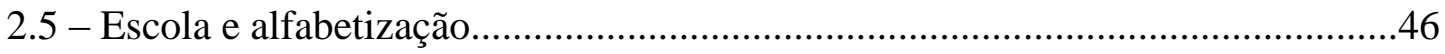

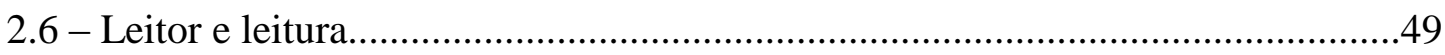

3 - UEA E INALD: INSTÂNCIAS DE PRODUÇÃO..........................................52

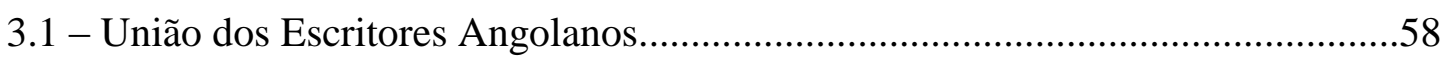

3.1.1 - Fundação, papel e relação com governo..........................................................58

3.1.2 - UEA, a alfabetização e a escola..................................................................66

3.1.3 - Números e coleções.................................................................................... 70

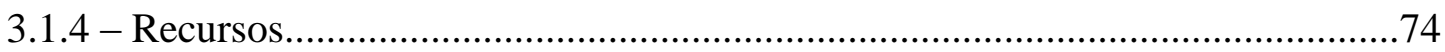

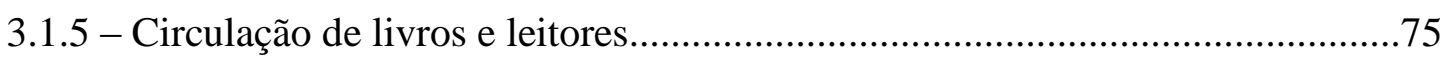

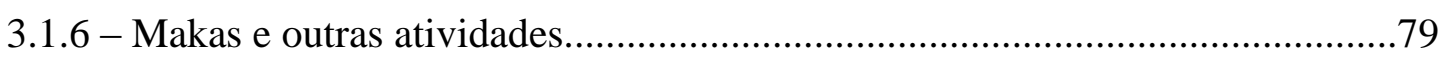

3.1.7 - Língua portuguesa, línguas nacionais e linguagem.....................................83

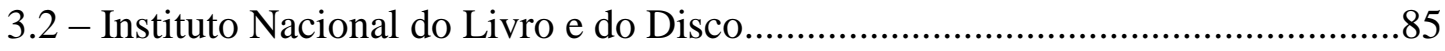

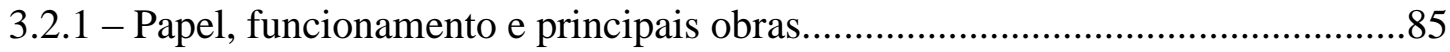

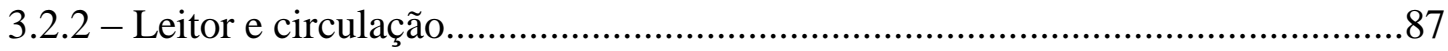

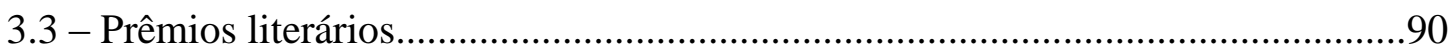

3.4 - O projeto literário e seu leitor - um balanço.................................................92

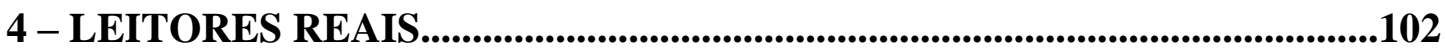




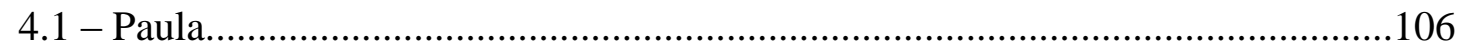

4.2 - Cassé

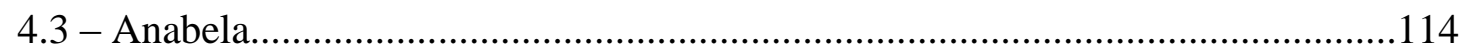

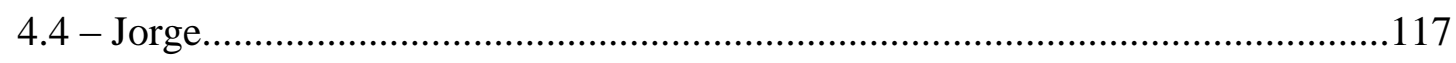

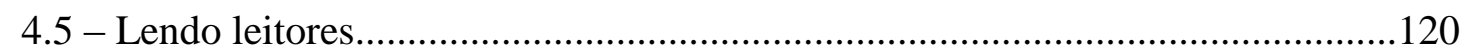

4.5.1 - Leitor em formação: bibliotecas familiares, leituras obrigatórias e

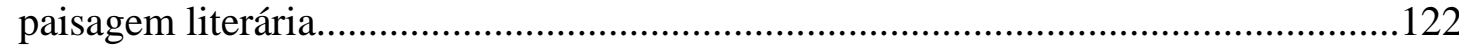

4.5.2 - O 25 de Abril e o novo cenário para os livros..............................................125

4.5.3 - Histórias de arrebatamentos: inflexões nas trajetórias dos leitores e o

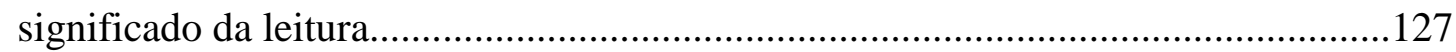

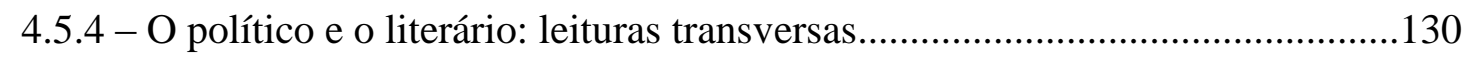

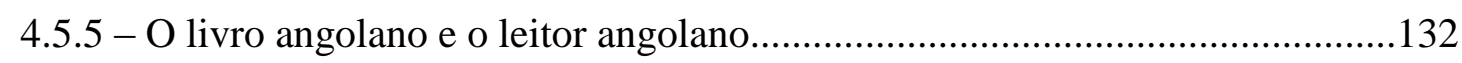

5- CONSIDERAÇÕES FINAIS.........................................................................137

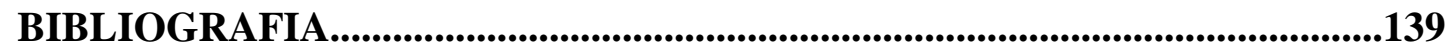

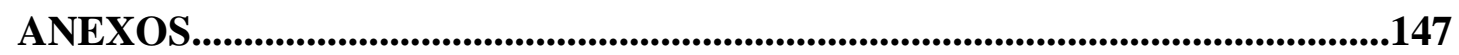




\section{CONSIDERAÇÕES INICIAIS}

Uma pesquisa nasce de uma inquietação, da ansiedade por descobrir algo que, se de alguma maneira já foi revelado, ao menos não parece tão nítido aos nossos olhos. Começamos então a explorar o universo de interesse, geralmente das questões mais amplas para as mais pontuais, fazendo perguntas e encontrando múltiplas respostas. Muitas são satisfatórias, outras delas, ou sobretudo sua ausência, nos mostram que é preciso seguir na escavação. Enquanto aquela curiosidade não cessa, intuímos que estamos no caminho. Enquanto a dúvida, por mais simples que se apresente, fica ali, nos provocando, sabemos que é preciso agarrar aquele fio, persistir na tentativa de desvelamento.

$\mathrm{O}$ encontro com as literaturas africanas de língua portuguesa foi um deslumbramento. Porém, mais que a qualidade dos textos, o assombro se deu pelo óbvio: ao longo de tantos anos amante de literatura, como nunca tinha pensado que, para além de Brasil e Portugal, há pessoas de outros países escrevendo na língua portuguesa, ainda que outra, ainda que modificada, ainda que embelezada pela cadência das línguas nacionais de cada região, ainda que com temáticas particulares? Neste momento apareceu a primeira agitação: quem são essas pessoas que estão escrevendo, sobre o quê, em que condições, com que tessituras? Para essas perguntas, foram muitas as respostas encontradas.

Avançando nesse tema tão amplo, ao ter contato com os movimentos culturais e literários que jogaram importante papel no processo de libertação das colônias portuguesas, a força daqueles que atuaram em Angola e a relação imbricada entre literatura e guerrilha capturou minha atenção. E neste país me detive. Em meio às questões que envolviam o contexto de produção, a leitura da prosa de autores como Luandino Vieira e Boaventura Cardoso me deliciavam e espantavam, me jogando de volta para o universo do extratexto: se essas obras, que continham uma ruptura formal com o português metropolitano, que me faziam recorrer a um glossário quase sempre insuficiente, porque a sintaxe também era outra, e que transformavam em protagonistas os personagens lindeiros, me causavam deleite, mas estranhamento, o que elas diziam ao leitor angolano?

Essa questão foi ganhando força, sobretudo ao conhecer o propósito do Movimento dos Jovens Intelectuais, grupo que liderou, em 1948, a ideia de "descobrir 
Angola" e foi um dos responsáveis por um fazer literário que se opunha àquele de cariz metropolitano, que acalentava a intenção de construir uma literatura feita por angolanos e também para angolanos, pressupondo assim a formação de um público leitor local e uma preocupação não apenas com a elaboração dos livros, mas com o que ocorre quando ele chega às ruas.

A pista final para concluir que a pergunta era, sim, relevante e merecia uma investigação foi a constatação inicial de que, na altura em que esses movimentos atuavam, nos anos que rondam a independência de Angola, a taxa de analfabetismo no país girava em torno de $97 \%$. Essa literatura tão profícua, que foi, de acordo com os teóricos, tão relevante no processo de construção de uma identidade nacional e, nas décadas seguintes, foi se consolidando a partir de uma diversidade de temas e de abordagens formais, estava destinada a um mundo sem leitores? Seria Angola um país da escrita, mas que prescinde de leitura? Quais seriam as características de uma literatura destinada, em última instância, a um público estrangeiro?

Definida a questão - leitor e leitura em Angola -, qualquer oportunidade em aulas, pesquisa bibliográfica e encontros com escritores angolanos era aproveitada para perscrutar o tema. Mas quase sempre, quando o leitor e a leitura passaram a ser a pergunta, as respostas ou eram evasivas ou terminavam com um taxativo "não se lê em Angola”.

Pesquisando em instituições de referência para a literatura em Angola, ainda em 2013, antes do início no programa de pós-graduação, seguimos constatando que pouco se sabe ou se estuda sobre o tema no país. Um breve mas significativo exemplo encontra-se na biblioteca virtual da União dos Escritores Angolanos, que reúne diversos artigos sobre a literatura da nação, redigidos tanto por escritores e críticos angolanos quanto por estrangeiros: dos mais de 200 artigos, apenas um se dedicava, ainda que não detidamente, à questão da recepção de textos, do leitor e da difusão da literatura ${ }^{1}$. Confirmamos que eram escassos não apenas grandes dados e números sobre produção editorial, comercialização e números de livros lidos, mas um trabalho que refletisse as minúcias da relação, estreita ou não, entre o livro angolano e o leitor angolano.

O campo, então, parecia mais que profícuo. E já sem volta. Aquele comichão inicial se acentuou, se fez imperativo, incontornável. E se nesse caminho múltiplas foram as possibilidades de abordagem, um fato foi determinante para que nos

\footnotetext{
${ }^{1} \mathrm{O}$ referido artigo é o de Luís Kandjimbo: A literatura angolana, a formação de um cânone literário mínimo de língua portuguesa e as estratégias da sua difusão e ensino.
} 
decidíssemos a começar por um momento significativo para o país, quando uma sucessão de acontecimentos faz com que a literatura, o livro precisamente, seja considerado objeto de prestígio na sociedade e quando o governo concentra uma série de ações para promover a leitura. Escolhemos o momento em que nasce o Estado, que começa a se narrar livremente, sem os entraves e censuras do colonialismo, e quando tem início de fato um projeto de formação de um leitor angolano, com esforços de várias instâncias para ampliar o público de livros no país. É também um momento a respeito do qual ainda é possível contar com as memórias dos artífices desse processo, um elemento essencial num país que, tendo padecido de tantos conflitos, possui acervos escassos ou comprometidos. O período analisado, portanto, compreende os anos de 1975 a 1991 que, conforme será posteriormente explicitado, possui uma certa homogeneidade no que tange ao fazer literário e à circulação de obras.

Diante da dificuldade, em muitos momentos incontornável, em se obter dados, documentos e estatísticas envolvendo os títulos publicados, as vendagens dos livros ou a relação de autores premiados, para ficar nas informações mais preliminares, recorrer à memória de interlocutores angolanos ou de portugueses com estreita vinculação ao país africano foi a principal estratégia para este trabalho. No entanto, essa interlocução vem não apenas preencher uma lacuna, mas oferecer uma contribuição significativa ao dar voz aos sujeitos, trazendo à tona reminiscências muitas vezes solapadas pela história oficial.

Este trabalho se propõe, portanto, a recontar um pouco dessa história redescobrindo Angola a partir de um olhar que em alguma medida se desloca de quem produz para quem lê Angola e, nesse movimento, ampliar o entendimento sobre esse complexo mosaico que é a literatura angolana, feita não somente de textos e narrativas, mas de pessoas nas quais essas obras ressoaram. Nesse sentido, o conceito de sistema literário proposto por Antonio Candido nos é de grande valia. Ele enxerga a literatura não apenas como resultado de manifestações literárias, mas em sua articulação com a sociedade, sendo fundamental para sua caracterização a "existência de um conjunto de receptores, formando os diferentes tipos de públicos, sem os quais a obra não vive" (CANDIDO, 2012, p. 25).

Entre as tantas ideias de leitor forjadas nos muitos campos que se dedicam a abordá-lo, a que perseguimos é aquela do leitor real, tão cara para a sociologia da literatura e para a história da leitura. O leitor, convergem as abordagens que utilizamos, é aquele que, ao concretizar o ato da leitura, permite a existência da obra literária, até 
então fixada, inerte, no objeto livro. Como tão bem sintetiza Alberto Manguel, "toda escrita depende da generosidade do leitor" (MANGUEL, 1997, p. 207).

Se o leitor dá vida à obra, muitos autores também concordam que sua liberdade não é total, de maneira que a leitura é resultado de um jogo entre aquilo que o livro, seu texto e sua forma determinam, e aquilo que o leitor, com uma relativa autonomia, recria ou ressignifica. A história da leitura, afirma Darnton, "terá de levar em conta a coerção do texto sobre o leitor, bem como a liberdade do leitor com o texto. A tensão entre essas tendências existe sempre que as pessoas estão diante de livros (...)" (DARNTON, 2010, p. 146).

É nessa intersecção que este trabalho pretende se desenrolar, reconhecendo as múltiplas influências a que um leitor está sujeito, mas também aceitando que nem toda a leitura é feita da mesma maneira ou determinada totalmente pelo autor. Valendo-me da ideia de literatura como sistema, ${ }^{2}$ que a pesquisadora Anita Martins Rodrigues de Moraes julga adequar-se aos estudos literários de outras literaturas de língua portuguesa, sobretudo em seu período de formação, proponho me fixar não apenas em alguns dos vértices do triângulo - obra e leitor, mas na comunicação que existe entre eles.

Antes de expor o resumo de cada capítulo, vale destacar ainda que estamos cientes de que falar de literatura angolana sugere uma totalidade que esta dissertação, e muito provavelmente a maioria dos outros textos, não conseguiria abraçar. As instituições e atores aqui analisados estão, em sua maioria, na cidade de Luanda. Porém, ao mesmo tempo em que avaliamos as formas de produção, circulação e leitura da capital, há sem dúvida um fluxo que parte de Luanda e que chega aos outros cantos do país.

Como afirma Tania Macêdo, Luanda é a imagem símbolo de Angola. Ela concentra, no período em questão e ainda hoje, não apenas grande parte da população de Angola (a estimativa na década de 60, por exemplo, é que Luanda reunia $40 \%$ da população citadina do país), mas uma série de instituições relevantes para toda a nação, a exemplo das sedes da televisão e rádio, da administração do Estado, da maior parte

\footnotetext{
${ }^{2}$ Ressalto que não nos interessa aqui questionar ou validar a solidez do sistema literário de Angola, tanto em seu período inicial quanto atual, já que diversos autores que se ocupam da literatura em África passam com propriedade por essas questões. Ana Mafalda Leite (2003) fala em "precariedade da instituição literária local", enquanto Benjamin Abdala Junior (2003) refere-se ao "macrossistema literário da língua portuguesa", incluído aí Angola. Rita Chaves (2012) afirma que hoje a literatura angolana já teria superado seu processo de consolidação, podendo falar de um projeto amadurecido diante de autores que trabalham temas e linguagens diversificadas, entendimento que vai ao encontro da percepção da professora Maria Nazareth Soares Fonseca, para quem "Angola tem uma instituição literária bem consolidada, com muitas obras publicadas no país e fora do país (2010).
} 
das universidades e dos jornais. Tania Macêdo afirma que "ela é, sem dúvida, a 'cidade da escrita de Angola”, que, além de reunir as citadas instituições, seria a única a possuir parque gráfico de porte, sendo o "local em que grande parte da literatura é produzida, lançada e comentada". "Não causa espécie, portanto, que a cidade seja referência obrigatória no imaginário nacional e cenário privilegiado da literatura produzida no país. Dessa forma, cremos que estudar a literatura produzida em Angola é obrigatoriamente referir-se a Luanda, sua história e sua gente" (MACEDO, 2008, p.14). Diante disso, e do fato de algumas de nossas fontes serem provenientes de outras regiões, optamos, portanto, em assumir essa relação metonímica Luanda/Angola, trazendo no título deste trabalho o nome da nação.

Feita essa explicação, informamos abaixo a estrutura que o leitor encontrará nessa dissertação:

Um $1^{\circ}$ capítulo teórico, em que será explicitada a maneira como diferentes correntes críticas lidam com o leitor. As ideias de sistema literário de Antonio Candido são algumas das que nos auxiliam a melhor entender os diversos agentes que compõem a instituição literatura, o público leitor entre eles, e seus mecanismos de atuação. O significado da história da leitura, e as revoluções que se sucedem no modo de ler ao longo dos séculos, assim como os autores que a abordam, a exemplo do francês Roger Chartier, também serão evocados, constituindo importante referencial metodológico.

Na sequência temos um $2^{\circ}$ capítulo que traz o panorama literário angolano nos anos que antecedem a independência e que ainda não são propriamente o objeto deste trabalho. Vamos mostrar os principais movimentos e instituições que compõem a paisagem angolana, a fim de situar o leitor e favorecer o contraponto com o projeto que vem com a independência, este sim nosso principal motivo.

O $3^{\circ}$ capítulo examina com vagar duas instâncias de produção, protagonistas da edição de livros e promoção da leitura no período que cobre essa dissertação, com o objetivo de entender o projeto literário da nova nação: a União dos Escritores Angolanos e o Instituto Nacional do Disco e do Livro (Inald). Apesar de dialogarmos aqui com duas instituições produtoras, não deixamos de perseguir o leitor que elas projetam e buscam formar. A interlocução com essas instâncias se deu a partir de entrevistas em profundidade com os dirigentes das entidades e com outras fontes envolvidas com o tema, de pesquisa de acervo e análise do material por eles produzido. Este capítulo é o que, de toda a dissertação, se fez mais extenso. Tendo em vista a dificuldade na obtenção dos dados, nossa escolha foi franquear ao leitor deste trabalho o 
maior número possível de informações que conseguimos coletar, sem nos preocuparmos com um eventual desequilíbrio entre as partes.

O leitor real emerge no $4^{\circ}$ e último capítulo da dissertação, com o intuito de buscar essa voz que comumente não é ouvida, mas que pode oferecer uma outra narrativa, que se complementa ou que se choca com a que conhecemos quando observamos a literatura a partir apenas dos autores e obras. Entender como o projeto literário, em muito encarnado pela União dos Escritores e pelo Inald, ecoou nesses leitores, a partir da construção de suas trajetórias de leitor, baseadas em suas memórias e percepções, foi o objetivo deste capítulo e de toda a dissertação. Traçamos um caminho talvez longo, mas essencial, para chegarmos até esses leitores reais, tantas vezes silenciados, oferecendo assim uma contribuição que se pretende uma mirada, se não original, ao menos mais ampla aos estudos literários de Angola.

Ao acompanhar o percurso realizado, o leitor reconhecerá que este trabalho se insere tanto nas discussões que legitimam a tríade autor-obra-público como aspectos essenciais da instância literatura, como se volta para o campo da história que estuda a equação livro-leitor-leitura e que tem se revelado um importante aliado para a compreensão dos fenômenos literários. 


\title{
1 - LIVROS, LEITURA, LEITORES: APROXIMAÇÕES TEÓRICAS
}

\author{
"Desde os primórdios, \\ a leitura é a apoteose da escrita"
}

Alberto Manguel

Ao observarmos um livro repousando na prateleira de uma biblioteca, o que vemos é um utensílio composto de folhas dobradas e encadernadas, nas quais se vislumbram, alternadamente, tinta e vazio. Solitários ou enfileirados aos pares, possuem cores e tamanhos ligeiramente variados, mas é fácil agrupá-los em uma mesma categoria de objeto: do antigo códex medieval ao impresso pós-Gutenberg, o livro, feito apenas de papel sobre papel e de caracteres ao lado de caracteres, não teve sua estrutura alterada a ponto de se redefinir num produto outro. Artefato material, ele pode dormitar entre tantos outros livros de qualquer biblioteca sem que revele as histórias que carrega, as teorias que preconiza, a poesia que acalenta. Ele segue imóvel, empoeirado ou não, sem que dele apreendamos mais do que essa forma que pouco anuncia. O que fará essa produção sair de seu estado latente é a inevitabilidade de um encontro. A tinta só se faz conhecimento ou comoção quando um olhar ali se detém, decifrando a seu modo o que alguém algum dia produziu. É quando o livro encontra seu leitor, que o retira do ocaso das bibliotecas adormecidas e dele se apropria, tateando-o, sorvendo-o, decodificandoo, que ele enfrenta o seu destino. É somente ali, na leitura, que ele se realiza e parte para cumprir a sua sorte.

A afirmação parece resvalar na obviedade: um livro só persiste quando alguém o lê. Ou como afirma o historiador Roger Chartier, “(...) um texto só existe se houver um leitor para the dar um significado" (CHARTIER, 1994, p. 11). Este entendimento, no entanto, demorou a ganhar força na teoria literária, em que o primado do texto se fez por anos valer. Ler o leitor, ou ler o livro a partir do leitor, foi atitude que encontrou certa resistência entre os círculos de teóricos, mas é pressuposto que hoje convive com os demais paradigmas da teoria, todos e cada um lançando luz sobre aspectos do texto ou da instituição literatura com o intuito de melhor apreendê-la. Nesse jogo, mirar no leitor é experimentar um dos muitos olhares possíveis, apostando nos ganhos que essa diretriz permite e assumindo também as limitações que ela nos oferece. É escolher uma vereda 
pela qual percorrer, um caminho que pode não ser o mais palmilhado, mas cuja travessia não se faz sozinho, e sim acompanhado de significativas referências.

\section{1 - Leitores possíveis}

Entre essas referências está a Estética da Recepção, escola que, pela primeira vez na teoria literária, lançou um olhar detido sobre o papel do leitor, por tantos anos preterido na significação da obra literária. Antoine Compagnon (2006) nos explica que, antes das teorias da recepção, que ganham força nos anos 70 do século $\mathrm{XX}$, o historicismo buscava a obra em seu contexto original, enquanto o formalismo evocava o texto em sua imanência, ambos concordando durante muito tempo em "banir o leitor", o que foi ainda mais bem formulado pelos americanos do New Critics. A obra, para essas correntes, era uma unidade autossuficiente e sua leitura deveria ser fechada, distante tanto de sua produção quanto de sua recepção ${ }^{3}$. Os teóricos alemães da Escola de Constança contribuem para mudar esse cenário.

Hans Robert Jauss, nome fundamental nos estudos da recepção, estava preocupado em desenvolver uma história da literatura que estivesse além da tradicional, centrada nas instâncias de produção, ou em seus autores. Partindo do pressuposto de que o significado da obra é encontrado na relação que estabelece com seu público em cada período histórico, Jauss defende que "a experiência das obras literárias pelos leitores, geração após geração, tornava-se uma mediação entre o passado e o presente que permitia ligar história e crítica” (JAUSS, 1994, p. 43). O que ele preconiza é o estudo, para cada obra, de sua recepção original pelo público e das sucessivas recepções que esse texto enfrentou ao longo de sua existência, pois a premissa é que é o leitor quem atualiza as obras literárias. Este leitor atuaria a partir de um horizonte de expectativas, que, de acordo com Compagnon, é “o conjunto de convenções que constituem a competência de um leitor (ou de uma classe de leitores) num dado momento; o sistema de normas que define uma geração histórica" (COMPAGNON, 2006, p. 156). Cada época ou sociedade, portanto, está sujeita a um horizonte de expectativas. É a partir desse horizonte que o público elabora seu julgamento da obra e, consequentemente, a

\footnotetext{
${ }^{3}$ A técnica conhecida como close reading caracterizou, entre outras escolas, o New Criticism, e consistia em uma leitura que dispensava os elementos externos ao texto, como biografia, contexto histórico ou componentes psicanalíticas, para se fechar em sua estrutura poética.
} 
situa diante das demais. Uma mesma obra, assim, pode assumir distintos significados, sem que sua interpretação seja estanque.

Wolfgang Iser, outro dos estudiosos da recepção, mais interessado nos efeitos individuais da obra e nos processos de leitura, desenvolve a categoria de leitor implícito, proposição que vem contribuir para um melhor entendimento da relação autor-textoleitor. O leitor implícito seria uma construção textual que prevê a presença de um receptor, ainda que sem defini-lo, e oferece as pré-disposições necessárias para que determinada obra provoque seu efeito. O leitor implícito não coincide com o leitor real, mas deriva de uma rede de estruturas que, exigindo uma resposta, força o interlocutor na leitura do texto. Este leitor

encarna todas as predisposições necessárias para que a obra literária exerça seu efeito - predisposições fornecidas, não por uma realidade empírica exterior, mas pelo próprio texto. Consequentemente, as raízes do leitor implícito como conceito são implantadas firmemente na estrutura do texto; trata-se de uma construção e não é em absoluto identificável com nenhum leitor real (ISER, 1996, p. 36).

Para Iser, o texto carrega uma série de indeterminações, lacunas a serem preenchidas pelo leitor. Como em um jogo, o texto oferece as cartas para que seu interlocutor jogue de uma maneira já demarcada, mas que pode ser atualizada pelo repertório próprio do leitor.

Os nomes de Iser e Jauss, brevemente aqui evocados com o intuito de demarcar as primeiras sistematizações mais intensivas em torno do tema, certamente não são os únicos a se debruçar sobre a instância leitor em uma obra literária ${ }^{4}$, mas ainda hoje constituem significativa referência quando o tema é a recepção de obras pelo público ${ }^{5}$.

O grande mérito da Estética da Recepção é, sem dúvida, o de tirar o foco da esfera da produção, operando um deslocamento no objeto da teoria literária, que deixa de ser o texto para se constituir na leitura. Em que pese o fato de que as categorias que oferecem para equacionar esse novo olhar nem sempre permitem sem adaptações a

\footnotetext{
${ }^{4}$ Entre os muitos teóricos que lançam luz sobre o tema estão Umberto Eco (1998), que construiu a categoria de leitor-modelo, Roland Barthes (1988), que dessacraliza o autor ao decretar sua morte, ou Stanley Fish (1992), com suas comunidades interpretativas, às quais os leitores pertenceriam.

${ }^{5} \mathrm{Na}$ dissertação defendida em 2005 e intitulada Nas malhas do leitor - um estudo de teses e dissertações sobre leitura/recepção de textos (1980-2003), Renata Macedo Capatto descreve e analisa vinte trabalhos produzidos nas principais universidades brasileiras sobre leitura e recepção de textos. Na quase totalidade deles (19 de 20), os autores da Estética da Recepção são referências centrais.
} 
aproximação com o leitor real, ou ao menos individualizado, é preciso pontuar que a escola provocou uma mudança significativa no panorama literário ${ }^{6}$.

Para além dos estudos literários, o leitor também ganha relevância nas correntes que buscam resgatar uma história da leitura, em uma perspectiva que não se resume ao enfrentamento do texto com o leitor, ou em sua recepção. Na tentativa de reconstruí-la, os trabalhos procuram resposta para a seguinte pergunta: quem lia o quê e, sobretudo, em que condições? As estratégias para respondê-la, no entanto, são distintas, todas envolvendo um esmerado labor em busca de pistas muitas vezes pouco usuais. Quanto mais distante no tempo o período que se pretende cobrir, maior a dificuldade e o trabalho do pesquisador para encontrar os registros possíveis. Nessa esteira, cada ponta é valorizada, pois pode ser rastreada e atada a outra, até formar um caminho que é seguro percorrer.

O francês Roger Chartier desenvolveu uma série de trabalhos sobre a história da leitura, escolhendo como objeto metodológico privilegiado o livro em si, pois acredita que ele carrega marcas tipográficas que revelam muito mais do que aquilo que o autor pôde e quis dizer. O livro é resultado de uma escolha, feita não apenas pelo autor. Chartier pretende, assim, romper com concepções abstratas de texto, autor e leitor, ao se fixar na materialidade do objeto livro. Se a leitura é móvel e fugidia, o escrito é fixo, durável, palpável.

Em suas pesquisas, Chartier defende que o leitor está, de certa forma, sujeito a algumas determinações do livro. "Esta independência fundadora (do leitor) não é, todavia, uma liberdade arbitrária. Ela é limitada pelos códigos e convenções que regem as práticas de uma comunidade de dependência. Ela é limitada, também, pelas formas discursivas e materiais dos textos lidos" (CHARTIER, 1994, p. 14). Essa ideia da relativa autonomia do leitor, que nos parece bem conceituada por Compagnon quando

\footnotetext{
${ }^{6}$ A compreensão que Jauss propõe da obra pelo público é medida pelo crítico, um leitor especializado, ou então feita a partir da reconstrução do horizonte de expectativas dos leitores, de maneira que desembocamos em um público, em um coletivo. Já o leitor implícito de Iser traz muito do leitor pressuposto pelo autor, pois é uma figuração presente no próprio texto. Comentadores como Compagnon assinalam o que seria essa limitação: "Jauss nunca estabelece distinção entre recepção passiva e produção literária (a recepção do leitor que se torna, por sua vez, autor), nem entre leitores e críticos. São, consequentemente, estes últimos - os leitores eruditos, que deixaram testemunhos escritos de suas leituras - os únicos que lhe servem de testemunhas para descrever os horizontes de expectativas. Ele jamais menciona os dados, muitas vezes disponíveis e quantificados, que interessam hoje aos historiadores, para medir a circulação do livro, em especial a do popular. O leitor continua sendo uma entidade abstrata e desencarnada em Jauss, que tampouco nada diz sobre os mecanismos que ligam, na prática, o autor e seu público" (COMPAGNON, 2006, p. 217).
} 
utiliza a expressão "liberdade vigiada", nos defrontará de maneira corrente neste trabalho.

$\mathrm{Na}$ mesma chave, a antropóloga francesa Michèle Petit expõe esse encontro entre livro e leitor que poderíamos categorizar como uma espécie de disputa que é a leitura:

O leitor não é passivo, ele opera um trabalho produtivo, ele reescreve. Altera o sentido, faz o que bem entende, distorce, reemprega, introduz variantes, deixa de lado os usos corretos. Mas ele também é transformado: encontra algo que não esperava e não sabe nunca aonde isso poderá levá-lo (PETIT, 2008, p. 28).

Chartier insiste que o objeto livro pode revelar muito sobre a leitura, pois é preciso destacar que não há texto sem suporte e

que não existe a compreensão de um texto, qualquer que ele seja, que não dependa das formas através das quais ele atinge o seu leitor. Daí a distinção necessária entre dois conjuntos de dispositivos: os que destacam estratégias textuais e intenções do autor, e os que resultam de decisões de editores ou de limitações impostas por oficinas impressoras (CHARTIER, 1994, p. 17).

Um dos exemplos que evoca para sustentar seu pressuposto é o da Biblioteca Azul na França. Essa biblioteca consistia em uma coleção de livros de venda ambulante, que circularam na França entre os séculos XVI e XVII em espaços rurais e periféricos. Fabricados em papel ordinário, constituíam brochuras de baixo preço. Como muitos deles possuíam capa azul, a biblioteca ficou conhecida por essa alcunha. Seus idealizadores se valeram de textos escritos em outro contexto para, trabalhando sua forma, voltá-los ao público popular e rural. Com isso Chartier busca apontar a distância entre a escrita do texto e sua forma editorial, que neste caso não foi originalmente pensada na perspectiva de uma edição barata ou de uma circulação popular. No entanto, com um trabalho de subdivisões dos textos e rearticulação dos parágrafos, de encurtamento ou subdivisões de capítulos, as obras foram alteradas, de maneira que a Biblioteca Azul apresenta-se como um indicativo de leitura que se pretende obter e um exemplo da importância das editoras na formação de um público leitor.

Sua persistência na análise do livro é porque, de acordo com ele, 
Reconstituir a leitura implícita visada ou permitida pelo impresso não é, portanto, contar a leitura efetuada e ainda menos sugerir que todos os leitores leram como se desejou que lessem. O conhecimento dessas práticas plurais será, sem dúvida, para sempre inacessível, pois nenhum arquivo guarda seus vestígios. Com maior frequência, o único indício do uso do livro é o próprio livro. Disso decorre também sua imperiosa sedução (CHARTIER, 1996, p. 105).

Assim, defende como metodologia possível para a escorregadia história da leitura, a interrogação aos próprios objetos, na tentativa de desvendar suas estruturas e os protocolos de leitura impressos nos textos. É nessa materialidade que é possível perceber as intenções de público ou de leituras, sobretudo para os que se dedicam aos períodos mais longínquos.

Em diálogo com Chartier e em uma perspectiva mais ampla, o historiador Robert Darnton propõe um modelo que abarca todo o processo de comunicação em que um livro está inserido, facilitando nossa visualização da teia de agentes que impactam na produção e na leitura de uma obra. Ele contempla, além de autor e editor, ambos imbricados na feitura do texto e do livro, a cadeia produtiva necessária para sua materialização, como fornecedores de tinta e papel, gráficos e encadernadores. Finalizado o objeto, entram em cena os distribuidores e livreiros, nas variadas formas que assumem ao longo dos séculos, de atacadistas e mascates. O livro chega então ao leitor, mediado pelas influências intelectuais e pela publicidade. Este leitor tem acesso ao livro pela compra, mediante empréstimo ou frequência a clubes e bibliotecas. Essa rede tem como pano de fundo as sanções políticas e legais que podem impactar sua produção, assim como a conjuntura econômica e social, que pode ou não impulsionar o livro. Este diagrama daria conta da visão holística que ele defende para a história do impresso. Para Darnton, cada elemento desse modelo merece ser estudado, desde que volte a se relacionado com o todo. Dentre todas as possibilidades, ele destaca que a leitura se configura como o ponto, nesse circuito dos livros, que representa maior dificuldade de estudo: "Apesar de uma volumosa literatura sobre sua psicologia, fenomenologia, textologia e sociologia, a leitura continua a ser misteriosa. Como os leitores entendem os sinais na página impressa? Quais são os efeitos sociais dessa experiência? E como ela sofre variações? (DARNTON, 2010, p. 145)

É preciso, no entanto, encontrar caminhos para recuperar esse passado, porque o que Darnton deixa claro em suas considerações é que "a leitura tem uma história". Ele aponta alguns deles ao citar o estudo do historiador Carlo Ginzburg, que entre os 
documentos da Inquisição do século XVI, encontrou em Menocchio, um humilde moleiro que estava sendo inquirido, um leitor possível de rastrear. Em resposta às perguntas sobre suas leituras, que buscavam uma possível acusação, ele desfila os livros lidos com rigor e seu impacto em sua formação. Menocchio leu larga quantidade de histórias de diferentes gêneros, acessíveis em bibliotecas nobres. É um leitor que pode ser considerado excepcional, mas não deixa de constituir um interessante registro sobre a leitura de uma época que já não se avizinha. E também a própria pesquisa de Darnton busca dar conta dessa dificuldade que é captar a leitura, ao analisar a trajetória de um sólido leitor de classe média - um comerciante chamado Jean Ranson - da França setecentista. A partir de uma série de cartas escritas por Ranson foi possível identificar a presença imperiosa de Rousseau no "tecido de sua vida", o que mostraria, de acordo com o autor, como o "rousseaunismo foi absorvido no estilo de vida da burguesia interiorana sob o Antigo Regime" (DARNTON, 2010, p. 170). É em tentativas como essas, mas também nas análises feitas em bibliotecas, nos catálogos de vendas dos livreiros e em correspondências de autores e documentos de editores, lugares onde estaria o que chama de "leitor de carne e osso" - categoria que está além do leitor implícito -, que é possível, por exemplo, nos deparar com uma situação inusitada como esta: o senso comum dos franceses do século XVIII, muito respaldado pelos estudos literários mais tradicionais, os faz crer que a literatura do período obviamente deveria incluir nomes como o de Voltaire. No entanto, ele definitivamente não é sucesso entre os livros retirados de um grupo de bibliotecas estudado. Havia outros livros mais lidos que, por não pertencerem a um certo cânone, desapareceram da história literária, o que faz Darnton concluir que se esses objetos forem estudados a partir do sistema de produção e difusão, podemos repensar nossa ideia sobre a própria literatura:

Tendo-a estudado (a história da leitura) como um fenômeno social, eles (os historiadores) podem responder a muitas perguntas sobre "quem", "o quê", "onde" e "quando", o que pode ser de grande auxílio para tratar as perguntas mais difíceis sobre os "comos" e os "porquês" (se lia) (DARNTON, 2010, p.171).

Com essas múltiplas perguntas que desembocam em distintos lugares, o que Darnton entrevê é uma intersecção entre teoria literária e história dos livros, pois se a teoria pode revelar o leque de reações potenciais de um texto, a história pode provar quais leituras de fato ocorreram. Portanto, ele diz, "eu defenderia uma estratégia dupla, 
que combinaria a análise textual e a pesquisa empírica. Dessa forma, seria possível comparar os leitores implícitos dos textos e os leitores efetivos do passado, e a partir dessas comparações desenvolver uma história e uma teoria da reação do leitor" (DARNTON, 2010, p. 195).

Em sua extensa e apaixonada Uma história da leitura, o ensaísta e romancista argentino Alberto Manguel percorre os milênios em que o ato de escrever, em variados suportes, e o de ler, de distintas maneiras, acompanham a humanidade. A partir de inúmeras fontes - representações artísticas, como pinturas e esculturas do homem na sua relação com o livro; relatos de leitura de filósofos, santos e pessoas comuns; avanços tecnológicos do aparato necessário para a confecção dos fólios; informações provenientes de bibliotecas e editoras; histórias de indivíduos envolvidos com a circulação do livro; indicações nos próprios romances, acervos de museus e trechos autobiográficos -, Manguel vai reconstruindo a história do artefato livro, sem nunca prescindir do homem que lê. Ele problematiza, sobretudo, a existência do livro no momento em que é colocado em circulação. Do "nebuloso ancestral sumério" lendo as placas de argila que representam os mais antigos exemplos conhecidos de escrita, até ele próprio, Alberto Manguel, o portenho que lê sentado em sua escrivaninha um livro dos tempos atuais, o esforço feito é no sentido de resgatar os gestos e as práticas que fazem de ambos, e dos milhares entre eles, membros de uma mesma comunidade. Essa comunidade se forma no partilhar do ato que pode ser sucintamente descrito como o de deter os olhos sobre as letras, extraindo dali algum sentido. É nisso, segundo o autor, que se resume a leitura.

Manguel pontua as mudanças que atravessaram esse ato da leitura, pois se muitos comungamos da mesma paixão, ela foi concretizada de maneiras distintas no correr da história. Essa história é feita de pequenas revoluções, sendo que diversos autores concordam com as passagens mais significativas que ocorreram nas práticas de leitura no Ocidente.

A primeira delas refere-se ao suporte da leitura. Quando o artefato que sustenta o texto deixa de ser os rolos de pergaminho para se transformar no códice, uma sucessão de páginas separadas e amarradas, o leitor não mais precisa realizar a leitura em pé ou utilizar as duas mãos para segurar os rolos, o que, de acordo com Martyn Lyons, liberou-o para que "pudesse ler e escrever, coçar-se, comer ou masturbar-se ao mesmo tempo" (LYONS, 1999, p. 16). 
Outra das revoluções apontadas seria a passagem para a leitura silenciosa, em detrimento da leitura em voz alta, extremamente ligada à prática da leitura íntima em contraposição à leitura pública. Se hoje a imagem de uma pessoa lendo sozinha em seu quarto é por demais comum, ela causaria espanto nos séculos anteriores ao XVIII, nos quais as noções de privacidade e intimidade eram outras. O que ocorre também é que entre 1750 e 1850, a relação tradicional e intensa entre leitor e texto, dada pelo livro como um objeto raro e reverenciado, torna-se obsoleta. Naquelas condições, os textos eram lidos repetidas vezes e memorizados, de maneira que a leitura em voz alta encontrava também aqui uma importante utilidade. Porém,

quando livros deixaram de ser raridade e se tornaram objeto de consumo cotidiano, a relação dos leitores com a palavra impressa se transformou. O livro se tornou parte familiar do mundo secular, e a leitura se tornou mais e mais individualizada, da mesma forma que a leitura silenciosa substituiu a leitura familiar ou coletiva (LYONS, 1999, p. 18).

Outra grande mudança, relativizada por alguns autores ${ }^{7}$, teria sido a passagem do texto manuscrito, de demorada execução, ao impresso em escala industrial pós Gutemberg. De qualquer maneira, todas elas, catalogadas como as revoluções presentes na história da leitura, só chegaram hoje ao nosso conhecimento pelo trabalho dos que se aventuram pela história da leitura. Como explica Marcia Abreu

Até alguns anos atrás não se imaginava que as formas de ler pudessem ter se alterado desde que o homem inventou maneiras de registrar conteúdos por escrito e formas de decifrá-los. Imaginava-se que a leitura sempre se fizera como supomos que ela hoje se faz, em silêncio e solitariamente, de modo a favorecer a concentração e o recolhimento. Supunha-se que, em todas as épocas, ler implicava pensar sobre textos e interpretálos, exigindo habilidades superiores à capacidade para decifrar os sinais gráficos da escrita. Acreditava-se que o contato com os livros foi sempre valorizado por favorecer o espírito crítico, tornando o leitor uma pessoa melhor por meio do contato com

\footnotetext{
7 Martyn Lyions, por exemplo, fala que "a imprensa não mudou imediatamente a natureza nem o assunto dos livros. Nem mudou, obviamente, o material - papel - de que os livros eram feitos. Foi preciso aparecer o computador para romper com dezessete séculos de produção livreira tradicional. A forma do livro - uma série de páginas costuradas ou coladas - manteve-se inalterada. Havia uma continuidade considerável, pelo menos de início, entre os livros impressos e manuscritos" (LYONS, 1999, p. 13). A invenção de Gutemberg, portanto, não ocasionou uma ruptura imediata na forma do artefato livro, tampouco em sua circulação, pois os livros continuavam nas mãos de uma diminuta elite, como provam inventários e testamentos.
} 
experiências e ideias registradas por escrito (ABREU, 2001, p. $1)$.

No entanto, como vimos, esses paradigmas foram sendo desconstruídos um a um, trazendo outras perspectivas a uma visão quase naturalizada sobre o papel do livro na sociedade e sobre as formas de nos apropriarmos desse objeto. Abreu relata que até mesmo um pressuposto que hoje nos parece inquestionável - a bonança que traz a leitura - já teve seus momentos de infortúnio:

A própria ideia sobre o valor da leitura já foi outra. Hoje ninguém tem dúvidas sobre a importância do ato de ler, tanto que organizações governamentais e nãogovernamentais fazem campanhas para que todos se tornem leitores. Nada poderia parecer mais horrível do que isso para alguns homens do século XVIII. Em 1775, por exemplo, o médico suíço Simon-Andre Tissot escreveu um livro intitulado $A$ saúde dos homens de letras, em que apresentava os perigos que a leitura oferecia para a saúde. Ele explicava que o contato com os livros prejudicava os olhos, o cérebro, os nervos e o estômago. Todo o organismo sofria, pois a leitura forçava a mente a trabalhar com intensidade ao mesmo tempo que mantinha o corpo em repouso durante longos períodos. $\mathrm{O}$ autor conta que, em sua prática clínica, encontrou os mais graves distúrbios de saúde, originados pela prática constante da leitura e da escrita (ABREU, 2004, p. 100).

Essas revoluções pelas quais passou a leitura, como dissemos anteriormente, são reconhecidas por diversos autores. Retomando Manguel, o que para ele permanece inalterado, apesar de todas essas transformações, é a inevitabilidade do leitor para que a escrita possa de fato existir:

A relação primordial entre escritor e leitor apresenta um paradoxo maravilhoso: ao criar o papel do leitor, o escritor decreta também a morte do escritor, pois, para que um texto fique pronto, o escritor deve se retirar, deve deixar de existir. Enquanto o escritor está presente, o texto continua incompleto. Somente quando o escritor abandona o texto é que este ganha existência. Nesse ponto, a existência do texto é silenciosa, silenciosa até o momento em que um leitor o lê. Somente quando olhos capazes fazem contato com as marcas na tabuleta é que o texto ganha vida ativa. Toda escrita depende da generosidade do leitor. Essa relação desconfortável entre escritor e leitor teve um começo: foi estabelecida para sempre numa misteriosa tarde mesopotâmica. Trata-se de uma relação frutífera, mas anacrônica, entre um criador primordial que dá à 
luz no momento da morte e um criador post-mortem, ou melhor, gerações de criadores post-mortem que possibilitam que a criação fale e sem os quais toda escrita está morta (MANGUEL, 1997, p. 207).

A morte do autor decretada por Manguel, que nos faz imediatamente pensar em Barthes $^{8}$, nos parece menos provocativa, indicando apenas que o livro só é considerado terminado quando o autor se retira, deixando o texto a sua própria sorte. Este livro ganha vida novamente no contato com o leitor. Para um existir, o outro deve se ocultar. Este encontro entre autor e leitor, portanto, nunca se dá. O encontro, que só acontece no ato da leitura, é entre texto e leitor. E aí o autor já não teria qualquer supremacia. Observemos essa mesma lógica na abertura que o escritor brasileiro Josué Montello faz em um de seus romances:

Sempre que tenho nas mãos um novo livro meu, eu o folheio, leio aqui um trecho, outro ali, depois lhe digo: agora trata de cumprir teu destino. Será louvado por uns, injuriado por outros, até que te deixem quieto, no teu vão de estante. É esse o destino de todos. Tanto os de Goethe quanto os de João Fernandes. Tua verdadeira glória, se acaso a tiveres, ocorrerá à noite, no silêncio da casa, quando alguém te vier buscar para que sejas teu companheiro de vigília. Vai. Que Deus te proteja. E te dê essa noite (MONTELLO, 1999).

O resultado deste encontro texto-leitor, ou a leitura, tem sido objeto do estudo das pesquisadoras Marisa Lajolo e Regina Zilberman, que se debruçam sobre esse fenômeno no Brasil. Tendo em vista a "identidade escorregadia" do leitor e da leitura, o trabalho assume uma feição poliédrica, buscando tocá-los de maneiras distintas, por aquilo que está em seu entorno e que os impacta. A primeira estratégia de aproximação de A formação da leitura no Brasil é buscar o leitor no texto literário, identificando o amadurecimento desse leitor a partir da ótica do narrador. É o autor, aqui, que dá mostras de como imaginava seu destinatário. Nessa textualização, que percorre nossas letras do século XIX e XX, as autoras revelam um leitor tutelado, que conta com a complacência e permissividade do narrador, muitas vezes temeroso de perdê-lo. Este leitor vai ganhando autonomia até atingir a maturidade, pela pena de Graciliano Ramos, que em São Bernardo faz do leitor seu grande parceiro.

\footnotetext{
${ }^{8} \mathrm{O}$ semiólogo francês, em seu clássico ensaio A morte do autor, defende que qualquer texto representa a destruição de toda voz, sem que possamos rastrear sua origem, e quem está a falar é a própria linguagem. A morte, portanto, estaria implicada nessa diluição.
} 
Outra das estratégias é se ater ao livro como artefato que permite a transmissão da literatura, resgatando os elementos necessários a sua confecção. Seu foco, desta maneira, é o autor e os problemas que enfrenta antes de sua profissionalização e de adquirir adequada remuneração. Partem então para o livro didático, material por excelência vinculado à formação do leitor real, na tentativa de entender como a experiência da escola pode, de alguma maneira, selar o destino dos leitores brasileiros. Ou como afirmam:

O livro didático, esse primo-pobre, mas de ascendência nobre, é poderosa fonte de conhecimento da história de uma nação, que, por intermédio de sua trajetória de publicações e leituras, dá a entender que rumos seus governos escolheram para a educação, desenvolvimento e capacitação intelectual e profissional dos habitantes de um país (LAJOLO \& ZILBERMAN, 1996, p. 121).

E nisso estão de acordo com Chartier, para quem "entre as leis sociais que modelam a necessidade ou a capacidade de leitura, as da escola estão entre as mais importantes" (CHARTIER, 1996, p. 240). O deslocamento posterior na obra de Lajolo e Zilberman se dá com a inclusão de um novo público leitor, o feminino, para quem se destinam publicações específicas, sendo aqui novamente o ponto de vista da produção da obra, pois é em sua caracterização que encontramos o perfil da leitora.

As autoras desenvolvem uma série de contornos, analisando as múltiplas perspectivas que envolvem a leitura, sem que tenha sido possível chegar diretamente ao leitor, defendendo que a história do leitor se mescla à história da modernização do país, ambos processos inconclusos. O extensivo trabalho de Lajolo e Zilberman aponta para uma noção de literatura que evoca a ideia de contexto, o que melhor permitiria compreender os "sempre renovados" pactos entre literatura e sociedade:

Um tal conceito de literatura afasta noções lineares de contexto e trabalha, em lugar disso, com a noção de contextualização contínua, onde cada elemento funciona como contexto do(s) outro(s), de modo que uma época, um autor, uma obra, um problema são, respectiva e reciprocamente, contextualizantes e contextualizáveis (LAJOLO e ZILBERMAN, 1996, p. 308).

Se é difícil chegar ao leitor na tentativa de reconstruir uma trajetória da leitura, quando o momento a ser a analisado é o presente, o pesquisador dispõe de mais 
recursos, seja pela abundância de registros ou pela possibilidade de conversar diretamente com os diversos interlocutores envolvidos no processo. Foi o que fez Michèle Petit, com o objetivo de entender o sentido da leitura para os frequentadores das bibliotecas públicas de lugares periféricos da França. Valendo-se de entrevistas em profundidade com os jovens que acessavam esses espaços, ela consegue reconstruir as histórias de leitura desses indivíduos, entendendo como o livro entra em suas vidas e como uma única frase lida pode representar um importante momento de inflexão de sua trajetória.

Petit acessou diretamente seus jovens interlocutores, os leitores "de carne e osso", e para além das grandes pesquisas estatísticas, conseguiu compreender que por meio da leitura, ainda que intermitente, eles "podem estar mais preparados para resistir aos processos de marginalização. (...) que ela os ajuda a se construir, a imaginar outras possibilidades, a sonhar. A encontrar um sentido. A encontrar mobilidade no tabuleiro social" (PETIT, 2008, p. 19). Na tentativa de entender a importância da democratização dos livros entre os jovens, ela recorreu diretamente a eles, sem qualquer intermediário, num bonito trabalho de antropologia da leitura.

Essas abordagens, para além do texto, dão conta da materialidade do livro e de como esse objeto circula, revelando algo aparentemente simples: é possível ler de maneiras diferentes, é possível ler a leitura de distintas formas. Elas estão no encalço não de um leitor implícito ou ideal, mas de um leitor real, que encomendou, comprou ou acessou o livro em uma biblioteca, que depois o leu ou simplesmente o guardou ou emprestou. Do leitor que buscou um livro porque a escola, a família ou o mercado o estimulou. De quem não leu porque não pode comprá-lo ou não sabia decifrá-lo. Com toda a dificuldade que o campo apresenta, pois recheado de intermediários, esses estudos nos dão importantes referências.

\section{2 - Papel do leitor no sistema literário}

Entre as perspectivas concernentes à teoria literária e aquelas ligadas à história da leitura, o crítico brasileiro Antonio Candido elabora uma teoria convergente, propondo a ideia de que autor, obra e leitor dependem um do outro. Com sua visão sistêmica da literatura, ele defende que elementos internos e externos aos textos concorrem e contribuem para sua formação e entendimento, mostrando como ambos estão imbricados. 
Comecemos definindo, juntamente com ele, o que é literatura, sendo fundamental a existência dos seguintes denominadores para que ela se configure como tal:

(...) um conjunto de produtores literários, mais ou menos conscientes do seu papel; um conjunto de receptores, formando os diferentes tipos de públicos, sem os quais a obra não vive; um mecanismo transmissor, (de modo geral, uma linguagem, traduzida em estilos), que liga uns a outros. O conjunto dos três elementos dá lugar a um tipo de comunicação inter-humana, a literatura, que aparece sob este ângulo como sistema simbólico (...) (CANDIDO, 2012, p. 25).

Estamos falando, assim, não apenas de obras e de textos em sua imanência, mas de autores, de público e demais mecanismos que fazem da literatura "aspectos orgânicos da civilização". Em seu entendimento, o leitor ou público seria um dos vértices da "tríade indissolúvel” proposta para se decodificar a comunicação artística, sem o qual os outros dois vértices - obra e autor - não se sustentam. O leitor, como nos explica em $O$ escritor e o público, ensaio integrante de Literatura e Sociedade, cumpriria um papel de mediador entre o autor e a obra, pois é o público que dá a referência ao escritor, que lhe permite a autoconsciência e que, por fim, lhe proporciona o conhecimento de si próprio.

Embora a ótica tenha um caráter que muitos afirmam sociologizante, por remeter a fatores externos, aqueles fatores que não são a matéria literária propriamente, nos parece fácil reconhecer, a partir da definição seguinte de Candido sobre literatura, o quão texto e leitor estão suficientemente relacionados para que este impacte diretamente a obra. Assim, preterir o leitor, mesmo o leitor não especializado, nos faz perder a dimensão ampla e complexa do objeto literário:

\begin{abstract}
A literatura é pois um sistema vivo de obras, agindo umas sobre as outras e sobre os leitores; e só vive na medida em que estes a vivem, decifrando-a, aceitando-a, deformando-a. A obra não é produto fixo, unívoco ante qualquer público; nem este é passivo, homogêneo, registrando uniformemente o seu efeito (CANDIDO, 2010, p. 84).
\end{abstract}

A fim de exemplificar como se dá esse contato, ao afirmar que "todo escritor depende do público", Candido mostra que nessa noção está implícito que o leitor e autor se relacionam a partir de diversas zonas de contato: o escritor busca um leitor, ainda que ideal, no qual sua obra encontrará ressonância; a aceitação do escritor, e a consequente 
remuneração de seu trabalho, dependem, ainda que em parte, da resposta do público; a produção do escritor volta-se, mesmo que muitas vezes sem desejar, aos interesses do leitor. $\mathrm{Ou}$, como afirmou o escritor angolano Boaventura Cardoso (entrevista concedida a Ligia Micas em 01 de março de 2013): “Antes de mais nada, escrevo para mim. Não escrevo a pensar nos gostos literários de quem me vai ler. Contudo, uma vez concluída a obra, aspiro ardentemente a ser lido por um número cada vez maior de leitores. Embora possa parecer um paradoxo, é a realidade. Uma obra literária que não tenha leitores não pode ser considerada como tal”.

Para explicar suas teses, Candido mostra como a orientação da literatura no Brasil foi influenciada pelo público disponível. Fixemo-nos em dois dos exemplos apresentados. É o nacionalismo, primeiramente, que vai produzir, no século XIX, um interessante encontro entre escritor e público, no que parece constituir uma verdadeira convergência de interesses de ambos os grupos: quando, no Brasil, o escritor passa a assumir a militância intelectual e o trabalho em nome da defesa da nação, encontrando um lugar social e manifestando os ideais nacionais em seus textos, consegue a ressonância no público. Este passa, então, a esperar desses autores temas referentes ao Brasil, que resvalem na produção da identidade nacional, que exaltem a pátria ou sobre ela reflitam. A partir daí, desse encontro entre autor e leitor e, portanto, do reconhecimento do valor dessa literatura, seus pressupostos passam a valer também para outras tendências, já que o público assim exigia. Candido afirma que "nativismo e civismo foram grandes pretextos, funcionando como justificativa da atividade criadora; como critério de dignidade do escritor; como recurso para atrair o leitor e, finalmente, como valores a transmitir" (CANDIDO, 2010, p. 80). Outro exemplo interessante resgatado por Candido foi o profusão de revistas e jornais familiares ao longo do século XIX, que levaram os escritores a escrever para um público específico: as mulheres. A consequência disso, de acordo com o crítico, é um estilo que marcou nossa literatura, feito de "fácil humorismo" e de "pieguice", que poderíamos ver mesmo em Machado de Assis.

O público leitor, portanto, é um desses elementos que podem determinar o caminho de um texto ou mesmo de uma tradição: Candido mostra isso ao argumentar que a pobreza cultural de nossas elites não permitiu a formação de uma literatura complexa, já que elas se definiam apenas pelo gosto pelas letras, mas não pelo refinamento. 
Em outro ensaio do mesmo Literatura e Sociedade, Candido expõe novamente esse mecanismo de interdependência e interrelação entre obra e público. Em seu estudo intitulado A literatura na evolução de uma comunidade, que busca sugerir o papel das formas de sociabilidade intelectual na caracterização das diferentes etapas da literatura brasileira em São Paulo, acompanhamos seus pressupostos.

Depois de relatar o que seria o início da literatura paulista em torno da Faculdade de Direito, criada em 1827, quando produtores e leitores constituíam um mesmo grupo, e as sucessivas etapas do processo, culminando com a formação de um público leitor - a burguesia -, Candido resume o encadeamento dos fatos:

Um grupo virtual, bruxuleando na cidade indiferente; um grupo ordenado, estabelecendo a tradição literária; um grupo ordenado e vivo, criando uma expressão à margem da cidade; a cidade absorvendo este grupo e chamando a si a atividade literária, que se ordena pelos padrões eruditos da burguesia culta; da cidade surgindo um grupo que rompe esta dependência de classe e, quebrando as barreiras acadêmicas, faz da literatura um bem de todos. Há uma história da literatura que se projeta na cidade de São Paulo; e há uma história da cidade de São Paulo que se projeta na literatura" (CANDIDO, 2010, p. 175).

Percebemos que, neste gradiente que é a formação de uma literatura paulistana,

o público ocupa um papel cimeiro. É somente quando os textos deixam de ficar contidos na esfera da criação e se tornam "um bem de todos" que a literatura se concretiza.

Buscando uma síntese das muitas ideias em torno do público leitor em Antonio Candido, podemos afirmar que, em uma esfera mais ampla, ele é indispensável para a literatura se constituir como tal, tendo em vista sua visão sistêmica do fenômeno; no que tange à materialização dessas relações, ao mesmo tempo em que um escritor delineia um público e busca atuar sobre ele, o público impacta o escritor, na medida em que aceita ou rechaça sua obra.

\section{3 - Atando os fios}

As teorias e categorias aqui evocadas, que emanam tanto de diferentes paragens do mundo ocidental, como de distintas áreas do conhecimento - crítica literária, 
sociologia, antropologia e história -, compartilham a importância de se olhar para a figura do leitor e para as práticas de leitura quando o objetivo é compreender o fenômeno literatura. Mas também entendem o leitor, o livro e a leitura como objetos que merecem ser estudados em si mesmos, detentores que são de uma história própria. A partir de diferentes metodologias, percebemos como é possível se aproximar do leitor, seja ele textual ou real.

Vislumbramos ainda que, da extensa cadeia dos objetos e sujeitos envolvidos neste campo, a leitura parece ser o que mais facilmente escorrega às tentativas de captura pelo pesquisador. Darnton e Manguel concordam com essa visão, atribuindo à prática um certo encanto advindo justamente da dificuldade de materializar algo que seria individual, múltiplo e fugidio, enquanto Lajolo e Zilberman buscam estratégias diversas para contar a história da leitura no Brasil, olhando por vezes para os livros e escritores, outras vezes para o leitor implícito, mas sempre tocando indiretamente a leitura.

Entendemos ainda, acompanhando os autores, que o livro, a leitura e o leitor, e ainda o texto literário, são faces de um mesmo campo, sendo difícil não recorrer a um quando se está a explorar o outro. Embora seja possível distinguir uma história do livro de uma história da leitura, por exemplo, o mais provável é que todos esses elementos apareçam no correr de um trabalho, ainda que haja um enfoque privilegiado.

Conseguimos ainda discernir entre dois objetivos mais comuns nessas áreas: se os estudos que se valem da Estética da Recepção como referência estão mais preocupados em entender a recepção de determinado livro por determinado grupo leitor $^{9}$, a história da leitura está centrada na reconstrução das práticas de leitura em diferentes tempos e lugares. Se na primeira sobressai o objeto literário, na segunda são as ações inerentes ao ato de ler e o artefato que as proporcionam - o livro. Como defende Darnton, na primeira instância, no âmbito da teoria literária, conseguimos entrever o leque de reações potenciais a um texto; já a história pode comprovar quais leituras de fato ocorreram.

Antonio Candido, sociólogo antes de se consagrar como crítico literário, possui uma estratégia que, ao recorrer a elementos internos e externos ao texto, parece combinar as duas possibilidades de análise.

\footnotetext{
${ }^{9}$ Trabalhos como, por exemplo, a tese de Pedro Egidio Warken (2015), intitulada A recepção de Machado de Assis por jovens leitores do século XXI, se ocupou de analisar a recepção de dois romances do autor por alunos do ensino médio de quatro colégios de Londrina.
} 
Nesta dissertação, que pretende mirar um momento histórico de Angola, quando a literatura ocupa um lugar de prestígio, e entender o lugar do leitor neste cenário - que leitor o projeto em vigor queria formar, como os leitores foram impactados por este projeto, qual a relação entre o livro angolano e o leitor angolano -, nossa escolha também foi por uma estratégia combinada, que posteriormente será detalhada.

Por ora, explicitamos que, das categorias e teorias apresentadas, extraímos os seguintes pressupostos como sendo de grande valia: a reconhecida importância de se olhar para as instâncias de recepção para compreender a ampla dimensão do fenômeno literário; o fato de que a leitura pode se concretizar de distintas maneiras, a depender do tempo e do lugar examinados; a ideia de que leitores reais podem contribuir sobremaneira para esse tipo de investigação; e que as abordagens metodológicas vão depender, em grande parte, do cenário e das adversidades encontrados. 


\title{
2- ANGOLA: INTERLÚDIO LITERÁRIO
}

\author{
"Eu queria escrever-te uma carta... \\ Mas ah meu amor, eu não sei compreender \\ por que é, por que é, por que é, meu bem \\ que tu não sabes ler \\ e eu - Oh! Desespero - não sei escrever também!"
}

É de conhecimento geral entre os estudiosos de literatura angolana o poema Carta de um contratado, de Antonio Jacinto, em que um eu lírico desvela o seu desejo de registrar no papel os sentimentos pungentes que nutre pela destinatária de suas palavras. A vontade de escrever uma carta - carta que marca, que fixa, que confidencia, que resgata a memória, que pode ser escondida e relida - inaugura cada estrofe do poema, assinalando as muitas funções que o texto escrito prevê. Querer ser autor, sem saber escrever, de uma carta destinada a alguém que não pode ler, problematiza de maneira poética as múltiplas questões que envolviam a temática da literatura no país. A urgência por uma produção literária local, em oposição àquela de viés metropolitano, e a necessidade de formação de um público leitor que se reconhecesse nessas obras, é apenas um dos aspectos que poderíamos evocar.

No texto poético o desfecho é carregado de dramaticidade e de impossibilidades, situação que por muito tempo guardou similaridades com a trajetória da literatura angolana, que enfrentou desventuras, sobretudo no período colonial, em que não apenas o número de leitores era restrito, como o escritor colonizado se postava diante de um impasse. Albert Memmi nos lembra que tanto do ponto de vista da produção quanto da recepção, a situação da literatura era, no mínimo, precária:

De fato, o papel do escritor colonizado é por demais difícil de sustentar: encarna todas as ambiguidades, todas as impossibilidades do colonizado, levadas a um grau extremo. Suponhamos que tenha aprendido a manejar sua língua, até mesmo a recriá-la em obras escritas, que tenha vencido sua profunda recusa a servir-se dela; para quem escreveria, para que público? Se se obstina em escrever em sua língua, condena-se a falar para um auditório de surdos. O povo é inculto e não lê língua alguma. Os burgueses e os letrados só entendem a do colonizador. Uma única saída lhe resta, que se apresenta como natural: escrever na língua do colonizador. Como se não fosse senão mudar de impasse! (MEMMI, 1977, p. 98) 
A história da escrita e da leitura no país, no entanto, não se resume à equação formulada de maneira delicada por Antonio Jacinto e exposta de forma vigorosa por Memmi. Tentemos então, neste capítulo, reconstruir esse panorama político e literário de enfrentamento na fase colonial até o momento em que começam a aparecer, em Angola, investidas mais efetivas de tomar para si a palavra e, assim, de se estabelecer uma literatura não apenas feita em Angola, mas de cariz angolano. Ofereçamos ao leitor deste texto um pouco da paisagem literária de Angola nos anos que antecedem a independência buscando iluminar esse período a partir de duas motivações: mostrar as primeiras movimentações na direção de uma literatura angolana, em grande parte forjada pelos intelectuais que também desenharam um projeto de nação, e revelar uma situação que permita o contraste do fazer literário no regime colonial com o que se estabelece com a independência, em 1975, e que é propriamente o objeto desta investigação. Avancemos no desdobrar daquilo que os versos de Jacinto suscitam.

\section{1 - A disputa pela palavra}

No período em que Portugal manteve colônias na África, sobretudo após a Conferência de Berlim, em 1885, quando se definiu uma ocupação mais sistemática do território, foram numerosos os esforços da metrópole para legitimar discursivamente a sua invasão. Travestida de missionária e civilizatória, a ocupação portuguesa em locais como Angola e Moçambique serviu a uma expropriação contínua dos recursos e força de trabalho desses territórios, ação esta largamente pautada na violência e na prática da inferiorização do outro, embora se buscasse continuamente uma justificativa pretensamente científica para a colonização, como nos mostra a fala do português Ayres de Ornellas no Congresso Nacional Colonial, em 1903:

Raças não só diferentes, mas cientificamente inferiores à nossa, com um modo de pensar e de sentir proveniente, é claro, da sua organização social tão diversa, da sua própria organização física tão diferente, com uma moral e uma religião opostas até à nossa, absolutamente incapazes, cientificamente falando, de adaptar os seus cérebros rudimentares e de curto período de desenvolvimento, às nossas complicadas teorias e à nossas elevadas concepções (1903, p. 13). 
O número 1 do Boletim Geral das Colônias, publicação oficial do governo português que teve início em 1925 e que circulava em Angola e nas demais colônias, em texto assinado por Armando Zuzarte Cortesão, então diretor do boletim, reitera esse entendimento ao alardear:

\begin{abstract}
A política colonial dos países que possuem colônias tem fatalmente de se orientar por estes dois grandes e basilares princípios: a) os indígenas das colónias devem ser considerados como seres humanos e não como simples animais, constituindo a sua educação e bem estar uma missão sagrada que a Civilisação delega nos povos colonizadores; b) a humanidade carece das riquezas inexploradas das vastas regiões coloniais, exigindo dos povos que as detêm a sua rápida utilização (CORTESÃO, 1925, p. 3).
\end{abstract}

"Justificada cientificamente" a inferioridade dos autóctones e a expropriação dos bens locais, abrindo assim um largo caminho para os desmandos coloniais, assistimos ao longo da primeira metade do século $\mathrm{XX}$ a construção de um discurso unilateral que foi acentuado quando, em 1933, teve início o Estado Novo português, sob comando de António de Oliveira Salazar, que buscava difundir a ideia de um Portugal uno, cujos limites não se encerrariam na Europa, mas abrangeriam todas as colônias do ultramar. Portugal, assim, unindo-se às colônias africanas de Angola, Cabo Verde, Guiné-Bissau, Moçambique e São Tomé e Príncipe, além das ocupações asiáticas de Timor e Gôa, seria um "país grande", discurso este que propositadamente ignorava as condições de conflito, tensões e desigualdades entre os portugueses brancos e os nativos negros e mestiços desses territórios.

É na esteira desse ideário que presenciamos aquilo que Manuel Ferreira chamou de "pirotecnia colonial", ou seja, toda uma série de instituições e práticas que serviram para corroborar a colonização, engrandecer Portugal e legitimar seu império diante da sociedade lusa e de seus interlocutores internacionais. Como nos aponta Francisco Noa,

segundo Manuel Ferreira com a implantação do Estado Novo, iniciou-se um frenético movimento propagandístico e cultural e ideológico (literatura, cinema, jornais, revistas, jornadas, semanas, slogans de glorificação do regime, programas escolares, congressos e exposições coloniais, prêmios de literatura colonial, paradas militares, viagens presidenciais ao Ultramar, criação da Agência Geral das Colônias, da Junta de Investigação do Ultramar), numa impressionante e desmedida 'pirotecnia colonial do Governo', em que 'nada e ninguém 
escapava a este vendaval da impunidade imperial' (NOA, 1999).

No que tange à literatura, é conhecido o concurso de literatura ultramarina, que em seu regulamento afirma que "será sempre preferida a literatura na forma de romance, novela, narrativa, relato de aventuras, etc, que melhor faça a propaganda do império português de além mar, e melhor contribua para despertar, sobretudo na mocidade, o gosto pelas causas coloniais". Como explica o historiador Alberto Oliveira Pinto, o Concurso de Literatura Colonial foi criado em 1926 e persistiu até 1951, sendo substituído, em 1954, por quatro prêmios literários, também instituídos por iniciativa da Agência Geral das Colónias (PINTO, 2012).

Em muito incentivada por este concurso, vemos como a literatura torna-se uma grande aliada do Estado Português e da empreitada colonial. Como nos mostra Luís Kandjimbo,

à semelhança do que se verifica em outros espaços africanos de colonização europeia, também em Angola emerge um romance colonial de pendor exótico e assente na mistificação racialista. Forma-se um conjunto de textos centralmente motivados por uma certa 'missão civilizadora' atribuída a personagens brancas, sendo as personagens de raça negra secundárias e vítimas na urdidura da história. É a chamada literatura ultramarina, designação que na década de 60 é substituída pela de literatura colonial. Em Angola, ela desenvolve-se a partir dos anos 20 deste século, com os concursos de literatura colonial portuguesa, promovidos pela Agência Geral do Ultramar e de estudos sobre uma Angola numa perspectiva etnográfica, englobando as línguas e o folclore (KAMDJIMBO, 2000, p. $59)$.

O que percebemos nessas passagens é o claro intuito do governo colonial português ser o detentor da palavra, a única voz altissonante, o primeiro e último narrador daquela história, valendo-se estrategicamente da literatura, entre outros meios, para consolidar esse discurso. Na literatura colonial produzida na metrópole ou nas colônias por homens que serviam ao propósito luso temos, assim, personagens, espaços, focos narrativos e linguagem que vêm confirmar um olhar português, sem que apareçam as contradições e tensões que se podia presenciar na realidade da relação ambígua e violenta entre o mundo do colonizador e o mundo do colonizado. Ou como explica Pires Laranjeira, ela era 
incentivada oficialmente para funcionar como instrumento ideológico do estado colonial, sobretudo para um público europeu (em Portugal) e colonial (os colonos e gente de permanência temporária), que mostrasse um imaginário de aventura e mistério e acentuasse a legitimidade da visão dominadora sobre o negro (...) A literatura colonial servia para devolver ao leitor a imagem do seu papel de desbravador de terras e civilizador de gentes, reiterando-lhe a consciência de um ser de condição e estatuto superiores (LARANJEIRA,1995, p. 27).

O discurso predominante, portanto, é marcado pela visão da metrópole, que detinha os meios e a autoridade para a concretização de seu ideário. Essa situação será aos pouco alterada quando se começa a investir na oposição ao domínio português, primeiramente no plano discursivo, e quando se inicia a gestação pelos angolanos de um projeto de construção da nação, o que ocorre na esteira do fim da Segunda Guerra Mundial, quando os ânimos em torno de uma emancipação política encontram ressonância.

\section{2 - Imprensa e o prenúncio da leitura}

O jornal se configura como o primeiro espaço que os angolanos encontram para iniciar esse projeto. E na tentativa de recompor um cenário literário em Angola, não podemos nos furtar a abordar a imprensa local, cujas relações são de constante imbricação. Sua produção tem início no país em 1845, com a chegada da primeira máquina de prensa.

Angola experimenta uma intensa atividade jornalística entre a segunda metade do século XIX e as cinco primeiras décadas do século XX. Entre 1860 e 1900 surgem cerca de 50 diferentes jornais que contribuíram para a atividade intelectual e literária e que possuíam relativa liberdade de expressão. É o caso de A Civilização da África Portuguesa, de 1886, que pedia o fim da escravidão, e do Jornal de Luanda, de 1878, liderado pelo escritor Alfredo Troni e que, de acordo com Pires Laranjeira, marca a transição de um jornalismo de tinta colonial para um tipo de publicação que acalenta os primeiros desejos nacionalistas. Merece ainda destaque neste cenário o periódico Ecos de Angola, criado em 1881 e publicado por 20 anos, considerado o primeiro jornal de africanos no país.

A partir de 1900 algumas publicações literárias demarcam com maior efetividade a importância da emancipação política em relação a Portugal: a coletânea de 
artigos não assinados Voz d'Angola - clamando no deserto, de 1901, e a revista Luz e Crença, de 1902. Depois de 1920 a censura começar a atuar com vigor, colocando fim ao período em que a imprensa gozou de liberdade para difundir suas propostas. De qualquer maneira, afirma Pires Laranjeira que

Esse desígnio jornalístico - ou melhor, de comunicação social, à letras - marcaria decisivamente os escritores de África, que quase sempre assistiam à divulgação dos seus textos através de compilações e antologias, antes de os poderem ver estampados em livros, um objecto a que poucas vezes tinham acesso, por dificuldades de várias ordens (LARANJEIRA, 1995, p. 20).

Este é o caso de obras como $O$ segredo da morta, de António de Assis Júnior, publicada primeiramente como folhetim no jornal A Vanguarda, em 1929, e editada em livro apenas em 1935.

Embora abundantes e fundamentais para a vida literária local, é difícil precisar hoje o alcance dos jornais no que diz respeito ao público leitor. Sabemos que uma pequena elite letrada tinha acesso a esse tipo de veículo, o que é reiterado ao observarmos algumas de suas tiragens. O importante Voz d'Angola - clamando no deserto, por exemplo, teve 1.000 exemplares, tiragem que foi paga de próprio bolso pelos autores, que permaneceram anônimos. Uma segunda edição, com 5 mil exemplares, só saiu em 1984, pela União dos Escritores Angolanos, mas já num contexto absolutamente diferente de sua produção original.

O jornal A Província de Angola, veículo de maior circulação nos anos que antecederam a independência, não teria passado dos 30 mil exemplares diários, enquanto o Diário de Luanda tirava entre 18.000 e 20.000 unidades ${ }^{10}$. A título comparativo, e esses paralelos não são mais que rasteiras ilustrações, tendo em vista as diferenças econômicas, culturais, de número de habitantes e de alfabetizados entre as nações, o jornal $O$ Século, periódico português fundado em 1881, chegava, no final do XIX, a 80.000 exemplares. Já o jornal O Estado de São Paulo publicava no Brasil, em 1967, 340.000 exemplares. Esses dados gerais, sabemos, não contribuem de maneira significativa para a questão da leitura, mas servem de indicativos iniciais, um

\footnotetext{
${ }^{10}$ Grande parte da bibliografia a que temos acesso não se ocupou de maneira sistemática desses números. Tampouco as publicações periódicas traziam em sua própria impressão o número de tiragem, como é o caso da Revista de Angola, publicada em Angola nas décadas de 60 e 70 e voltada ao público português, ou do Jornal Magazine - um jornal de Angola para o mundo português, que era impresso em Luanda, ambas publicações a que tive acesso na pesquisa do acervo da Biblioteca Mario de Andrade. Assim, recorremos a escassos textos publicados hoje em jornal em que é possível pinçar uma ou outra informação, talvez sem a desejada segurança.
} 
estranhamento necessário para começarmos a deslocar nosso olhar da produção para a recepção dos textos.

\section{3 - Publicações Imbondeiro: o livro em Angola}

Embora o jornal fosse um meio privilegiado para a expressão literária de angolanos, o país também contou com uma editora que cumpriu o papel de dar voz aos escritores locais. A Publicações Imbondeiro atuou entre 1960 e 1964, possibilitando que textos de autores diversos do universo lusófono, então chamado ultramarino, chegasse às mãos dos angolanos. Criada por Leonel Cosme e Garibaldino de Andrade, a Imbondeiro tinha sua sede na então cidade de Sá da Bandeira, hoje Lubango, capital da província de Huíla. Durante os cinco anos de existência, foram publicadas diversas coleções que buscavam não apenas dar conta da multiplicidade de vozes em língua portuguesa, como também fazer chegar aos angolanos alguns clássicos da literatura universal, como Bertold Brecht, Guillaume Apollinaire e Pablo Neruda, reunidos na Colecção Mákua.

A intenção da editora, como afirma o fundador Leonel Cosme, estava ligada ao nome escolhido, “de uma mítica árvore em Angola que, pela sua presença em todo o território, longevidade, tamanho e aplicações diversas, alimentares e medicinais, serviria como símbolo do projecto em vista”. O primeiro caderno da Colecção Imbondeiro, de 1960, traz mais dados sobre as pretensões da editora no texto intitulado propósito da novel editora, conforme nos explica um dos fundadores, Leonel Cosme:

Duas razões nos levaram a lançar esta colecção: a necessidade de dar a conhecer ao público português os valores ultramarinos que se espalham pelos cantos do mundo onde se fala a língua lusíada, desde a Guiné até Macau, e o direito, que se impõe, de os manifestar conjuntamente à luz duma consciência nacional que não pode deixar de reconhecer, nos caprichosos tons da grande aguarela lusitana, um curioso tema de interesses recíprocos, solicitados por anseios de espírito ou por afinidades de cultura tradicional. Não se passará, imediatamente, duma tentativa em moldes simples (tão dependente de variados factores), traduzida em trabalho breve, mas responsável, como é o conto: explica-a, de resto, esta forma primária da Literatura, que, seja em Angola como em Moçambique, não possui, por ora, arcaboiço adulto, com recursos igualáveis aos de uma terra de antiga existência literária. Mas, dentro da estreiteza das possibilidades, será nosso intuito cumprir a tarefa com o melhor aproveitamento dos muitos valores esparsos, maiores ou 
menores, que ainda hibernam - na espreita duma aurora que cesse a já longa escuridão - à sombra dos braços clamorosos dum velhíssimo imbondeiro... (COSME, 2014)

A editora, assim, segue numa via de mão dupla, publicando autores angolanos no país e fora dele, e levando autores consagrados, como Lygia Fagundes Telles, para ficarmos no caso brasileiro, ao público angolano. As tiragens da Imbondeiro, que publicou em sua totalidade 68 cadernos mensais e seis antologias, chegavam a 2 mil exemplares, e possuíam interessante sistema de distribuição: a venda se dava por assinaturas.

De acordo com Leonel Cosme (entrevista concedida a Ligia Micas em 25 de maio de 2015), os cadernos das diferentes coleções da Imbondeiro chegaram a todos os países de língua portuguesa, "especialmente por meio de assinaturas, que foram milhares". Fora de Angola, a prospecção de leitores era assumida por "delegados", papel que no Brasil, por exemplo, foi abraçado pelo escritor e jornalista do Estado de São Paulo João Alves das Neves.

Em Angola circulavam, além das coleções, os livros, distribuídos diretamente às livrarias, naquilo que era o primeiro movimento editorial organizado em Angola. Leonel Cosme relata que entre os leitores estavam indivíduos que pertenciam a "todas as classes sociais", tanto portugueses como os naturais da então colônia. "Obviamente, predominavam os amantes da leitura e, entre estes, candidatos à publicação", afirma Cosme, lembrando que o propósito da Imbondeiro "foi dar sentido à lusofonia, através de uma cultura comum, numa visão eclética e cosmopolita, alheia, do ponto de vista editorial, a diferenciações ideologico-políticas".

No Boletim Notícias de Imbondeiro $\mathrm{n}^{\mathrm{o}}$ 30, de 1962, texto assinado pelo mesmo Leonel Cosme diz que a Imbondeiro "não tinha um claro viés ideológico, publicando a expressão de cultura angolana branca ou negra, sem obrigatório engajamento". No jogo de publicar autores proibidos pelo regime em coleções que também publicavam autores caros ao salazarismo - ou como afirma Pires Laranjeira, no jogo entre "cedências ao campo literário conotado com o salazarismo, por estratégia de amplitude e de manutenção" e o espaço doado à angolanidade - a Imbondeiro conseguia um equilíbrio que permitiu sua existência.

O papel das publicações foi sem dúvida precursor: num momento em que a luta anticolonial armada assistia a seus vigorosos impulsos iniciais, a Imbondeiro não 
hesitou em publicar ou tentar publicar nomes como Luandino Vieira, que produziam, por distintos caminho, uma crítica ao regime. Ela foi responsável ainda pela realização, em 1963, do I Encontro de Escritores de Angola, reunindo nomes como Óscar Ribas e Henrique Guerra, além de escritores moçambicanos, cabo-verdianos e portugueses.

Não à toa a editora teve suas atividades encerradas em dezembro de 1964 pelas perseguições da Polícia Internacional e de Defesa do Estado (PIDE) português, deixando uma lacuna na edição de livros em Angola.

\section{4 - Literatura em movimento}

Neste cenário das incipientes letras, a literatura acabou desenrolando papel fundamental no processo de efetiva retomada da autoria do discurso angolano, servindo como eficaz estratégia de combate contra o colonialismo armado e cultural, na medida em que fortalecia a ideia de uma comunidade imaginada e forjava os elementos constitutivos da identidade nacional (ANDERSON, 2006). Tanto os estudiosos do tema quanto a própria narrativa angolana credita ao Movimento dos Jovens Intelectuais, criado em 1948 sob o lema "Vamos descobrir Angola", o impulso a uma produção de fato angolana, em detrimento da portuguesa que predominava até então. Seu manifesto preconizava uma arte feita por angolanos e para angolanos, e assim, juntamente com a música, o teatro, o jornalismo e outras diferentes formas de expressão, a literatura caminhou no sentido de encontrar um país que jazia sob a imposição dos valores portugueses.

O movimento teve origem na Associação dos Naturais de Angola (Anangola), e sua primeira publicação foi a Antologia dos novos poetas de Angola, que reuniu nomes como António Jacinto, Maurício de Almeida Gomes e Viriato da Cruz. O intento do grupo, de acordo com Pires Laranjeira, era produzir uma poesia revestida de angolanidade, uma poesia que se enquadrasse "no universo de ideias, aspirações e sentimentos do grupo ilustrado e esclarecido de angolanos que sonhavam com outro estatuto para si e para o território" (LARANJEIRA, 1995, p. 70).

É na esteira deste movimento e na mesma Anangola que vemos surgir, em 1951, a revista Mensagem, encabeçada por Viriato da Cruz, Antonio Jacinto e Agostinho Neto. Com breve trajetória - a revista publicou duas edições, sendo que a segunda reunia três números -, ela foi um marco da produção angolana, acalentando uma poesia reivindicativa. Segundo Carlos Ervedosa, foi "o suficiente para que a semente lançada à 
terra germinasse, criasse raízes e se desenvolvesse numa mafumeira portentosa, que indiferente às ervas daninhas que crescem à sua volta, resiste às inclemências do tempo e dos homens" (ERVEDOSA, 1963, p. 37). Além de textos dos poetas citados e de Mário António, Mário Pinto de Andrade e António Cardoso, Mensagem publicou ainda autores moçambicanos como Noémia de Sousa e José Craveirinha, associando-se, assim, a uma contestação mais ampla que ligava Angola a outras colônias portuguesas. A revista posicionou-se em sua segunda edição pelo desejo de independência, contribuindo para caracterizar o período entre o fim dos anos 40 e os anos 50 como crucial na formação da literatura angolana.

Um acontecimento de que não devemos nos descuidar neste período é a criação do Movimento Popular de Libertação de Angola (MPLA) ${ }^{11}$, ator fundamental no cenário político angolano, tendo assumido o país no pós-independência e protagonizado as muitas disputas ocorridas no território. O MPLA nos interessa não apenas por sua ampla influência nos desígnios do país, mas porque muitos dos escritores aqui citados, como Agostinho Neto, Viriato da Cruz e António Jacinto, integraram o movimento, promovendo uma estreita relação entre atividade intelectual, política e literária.

Em 1957 a revista Cultura (II) inicia sua publicação, se oferecendo como herdeira dos mensageiros e trazendo novos nomes à cena literária, como Antonio Cardoso, Henrique Abranches, Henrique Guerra e Luandino Vieira, que estavam à frente do projeto. Editada pela Sociedade Cultural Angolana, a publicação teve vida mais longa, chegando a 1960 e a 12 números. Vejamos sua proposta no editorial do primeiro número:

Jornal Cultura aparece, portanto, como consequência e correspondendo a uma necessidade actual de debate de ideias, de estímulo à crítica e onde o modo de pensar de cada um, estando presentes, possam criar um intenso e verdadeiro plano cultural de que Angola tanto necessita. Não nos cabe esboçar um plano. Cumpre-nos, isso sim, propiciar (...) os meios pelos quais hão-de tomar forma, ganhar relevo e conteúdo, as expressões de todos aqueles que são efetivamente capazes de escrever verso ou conto, de estudar ou analisar, de criticar ou equacionar, os diferentes problemas de toda a ordem que se põem em Angola.

\footnotetext{
${ }^{11}$ Há controvérsias sobre a data de criação do movimento. Enquanto o próprio MPLA cita o ano de 1956, alguns autores, a exemplo de Carlos Pacheco (1997), afirmam que teria sido anos mais tarde.
} 
Apesar de uma proposta abrangente e aberta, Cultura (II) apresentou textos que revelavam seu posicionamento político de uma Angola independente. E se, como afirma Ervedosa, a Mensagem colocou em cena o melhor da poesia angolana, Cultura revelou o "maior contista e novelista de sempre", Luandino Vieira.

Em 1961, há o início da luta armada e a intensificação das tensões, o que acaba por se refletir também na literatura, de maneira que escritores como Luandino, Uanhenga Xitu, Manuel Pacavira, Jofre Rocha e Aristides Van-Dúnem são presos por conta de "atividades subversivas". Muitos deles seguem produzindo, mas seus textos muitas vezes circulam por canais subterrâneos e clandestinos.

Esta literatura, que hoje, distantes no tempo, vislumbramos em uma pretensa totalidade, vai sendo cerzida aos poucos e em difíceis condições materiais, tendo sido publicada em grande parte em frágeis suportes. Conforme nos mostra Russell Hamilton, Luandino Vieira escreveu diversas obras em seus anos na prisão de Luanda e no Campo de Concentração do Tarrafal, uma delas Vidas Novas:

As oito estórias curtas de Vidas Novas são casos exemplares destinados a encorajar um nível de resistência contra a máquina colonial e a sua nefária política secreta. Portanto, estas histórias algo panfletárias existiam nos anos 60 e primeiros anos da década de 70 como uma literatura subterrânea que circulava em manuscrito até serem publicadas em Paris, provavelmente em 64, por Edições Anti-Colonial (HAMILTON, 1975, p. 133).

Hamilton afirma ainda que "as atividades literárias subterrâneas levadas a cabo no exílio e na prisão exerciam, então, uma influência direta nas atividades literárias em Angola nos primeiros anos da década de 70, mesmo quando determinadas obras clandestinas não estavam disponíveis" (HAMILTON, 1975, p. 152).

Assistiu-se assim, nas décadas de 50 e na subsequente e profícua década de 60, a um projeto literário que possuía um caráter eminentemente político, em que predominava a afirmação dos valores nacionais tanto no plano formal como na temática que perfazia grande parte das obras.

Como elucida Maria Aparecida Santilli (1985), a produção dos grupos que se reuniram em torno do movimento e das revistas Mensagem e Cultura (II) pautava-se na redefinição e valorização das características nacionais, na ideologia da resistência, no retrato do angolano comum e trabalhador, tendo os musseques como cenários privilegiados, na tensão entre colonizado e colonizador e no resgate ou reconstrução de uma linguagem própria. Os textos deste período deram lugar aos desterrados em seu 
próprio território, colocando em cena uma Angola que se fazia real, mas que até então não figurava no plano discursivo.

O escritor Pepetela, a partir de breve análise de dois autores chave das décadas de 1950 e 1960, sintetiza a tônica da literatura deste momento:

(...) a poesia de Viriato da Cruz, embora escassa e pouco divulgada, marca a divisão das águas e é a que, por todos os ângulos pelos quais possa ser observada, apresenta um corte definitivo com a portuguesa e tem todos os ingredientes de uma literatura verdadeiramente angolana. Os temas são inegavelmente angolanos, as figuras humanas também e mesmo a linguagem é o prenúncio do resgate de palavras, expressões, novos conteúdos semânticos e sintácticos, influenciados pelas línguas africanas. Foi de facto a poesia de Viriato que abriu o caminho para Luandino Vieira na prosa da década seguinte (PEPETELA, 2010).

Assim, além desta temática específica, a produção de então experimentou, neste intuito de falar ao homem angolano, de maneira que ele se reconhecesse no outro e em sua nação, um esmerado trabalho formal do texto literário: a literatura rende-se à oratura, o kimbundo passa a figurar ao lado do português, que vê sua estrutura modificada ou acrescida, a estrutura do mi-sosso é incorporada pelo texto escrito e, entre outras mudanças, começam a despontar as tantas vozes e perspectivas suplantadas ao longo do período colonial por uma produção que se dava em Angola mas que, na realidade, era estrangeira.

\section{Como explica Francisco Noa}

Se é verdade que grande parte dessas vozes pertence às elites maioritariamente educadas segundo os preceitos culturais, ideológicos e estéticos do antigo colonizador, não é menos verdade que elas instituem falas e visões do mundo que se contrapõem ao imaginário dominante, quando não o subvertem. Por outro lado, transformam a escrita num espaço de intermediação que permite a visualização e a legitimação de seres e de linguagens que, de outro modo, se manteriam silenciadas e obscuras ou, então, devido a mecanismos de apropriação, diminuídas ou caricaturadas em relação à sua real dimensão (NOA, 2009, p. 97). 
Este breve resumo de quase três décadas da literatura angolana, de 48 a 75, quando se dá a independência, buscou apenas pontuar seus momentos de maior expressão, suficientes para entendermos a posição de Amílcar Cabral, que afirma que

\begin{abstract}
o estudo da história das lutas de libertação demonstra que são em geral precedidas por uma intensificação das manifestações culturais, que se concretizam progressivamente por uma tentativa, vitoriosa ou não, da afirmação da personalidade cultural do povo dominado como ato de negação da cultura do opressor. Sejam quais forem as condições de sujeição de um povo ao domínio estrangeiro e a influência dos fatores econômicos, políticos e sociais na prática desse domínio, é em geral no fato cultural que se situa o germe da contestação, levando à estruturação e ao desenvolvimento do movimento de libertação (CABRAL, 1970, p. 361).
\end{abstract}

Este parece ter sido o caminho traçado em Angola, em que os movimentos culturais exerceram importante papel naquilo que culminou com a luta anticolonial. Como nos mostra Rita Chaves, "num mundo que a contaminação colonial povoou de colisões e desacertos, a literatura será uma das vias escolhidas para a formação de um mosaico capaz, ao menos, de sugerir alguma noção de unidade" (CHAVES, 1999, p. 20).

Pascale Casanova, em sua República Mundial das Letras (2002), afirma que há duas grandes estratégias que fundam todas as lutas dentro dos espaços literários nacionais: são elas a assimilação, que recorre à integração mediante a diluição das diferenças em relação ao espaço literário dominante, e a diferenciação, que é reafirmada sobretudo a partir de uma reivindicação nacional. Para ela essas são as soluções comumente encontradas nos momentos de surgimento de um movimento de reivindicação nacional ou da própria independência. Este último caso, o da diferenciação, foi a opção de Angola que, embora escolhendo majoritariamente a língua portuguesa para fazer desabrochar sua produção, insistiu em uma ruptura formal e temática com a metrópole.

\title{
2.5 - Escola e alfabetização
}

Ao buscarmos deslocar nosso olhar das instâncias de produção para as de recepção, cabe pousar com mais vagar na instituição escola, fundamental na 
conformação de um sistema literário, constituindo local de alfabetização, formação e de influência no gosto literário.

Durante o período colonial, o sistema em vigor era muito restrito. Devido à decisão do governo português de não investir na educação da colônia, o ensino de missões foi, por muitas décadas, a base da instrução e da assimilação dos angolanos. Embora já existissem anteriormente, em 1921 as missões passam, por decreto, a assegurar a maior parte das aulas de língua portuguesa em Angola. Essa situação perdurou até a década de 1950, o que muda na década seguinte, com o governo ampliando seu programa de ensino, muito em função das pressões internas e externas decorrentes dos movimentos independentistas (WHELLER \& PÉLISSIER, 2013).

Essa situação de precariedade impactou sobremaneira o número de alfabetizados no país, que era irrisório. O último censo feito em Angola, ainda no período colonial, em 1970, apontava que o país tinha uma população estimada de 5,6 milhões de pessoas. Deste total, apenas 3\% era alfabetizada, entre eles os brancos que viviam no território e uma pequena parcela de negros e mulatos assimilados que puderam frequentar a escola.

Nas escolas de missões ou do governo, o número de crianças e jovens que frequentavam uma instituição de ensino era mínimo. Entre 1955 e 1956, o número de alunos na rede (ensino primário, secundário e secundário técnico), abarcando colonos e colonizados, era de 74.652. Entre 1960 e 1961, há um expressivo aumento, chegando a 117.768 nos três níveis de ensino. O número de estudantes, todavia, segue pouco significativo: eles representam não mais que $2 \%$ da população angolana dentro da escola, enquanto havia ao menos $15 \%$ em idade escolar. No nível universitário, a situação é também de precariedade. Entre 1966 e 1967, frequentavam o ensino superior, inaugurado em 1962 em Angola, 607 alunos. Vale lembrar que os cursos de Letras e de Direito ainda não tinham sido iniciados.

A verdade é que, nesses anos que antecederam a independência, Angola era um país majoritariamente rural, com pouco acesso aos diversos tipos de instituições: em 1961, apenas $11 \%$ a $12 \%$ da população total era urbana, sendo que somente em cinco cidades os habitantes superavam a cifra dos 20 mil: Luanda, Benguela, Lobito, Nova Lisboa (Huambo) e Sá da Bandeira (Lubango). Na capital Luanda fixava-se cerca de $40 \%$ da população citadina.

A escola era lugar para poucos, majoritariamente brancos. E os angolanos negros e mestiços que tinham acesso a ela estavam sujeitos às tensões presentes na sociedade $\mathrm{e}$ ali reproduzidas. O conto Menina Vitória, de Arnaldo Santos (1985), nos sugere um 
impiedoso retrato da escola nos tempos coloniais, ambiente de intolerância e reafirmação dos valores metropolitanos. Gigi (Higino), garoto do musseque mas que podia se "considerar como um branco", filho de homem branco com uma mulata, mas "senhora de princípios", começa a frequentar um colégio caro, em que meninos "arranjadinhos" eram levados à porta pelas mãos dos criados ou mesmo de carro. Sua professora, a menina Vitória, também era mulata, mas tinha formação na metrópole e, afeita que era aos meninos de "cabelos alourados e sedosos", rapidamente alocou Gigi no fundo da sala, junto ao Matoso. Matoso, menino de pele muito escura e falante de quimbundo, era constantemente vítima de palavras e olhares recriminadores, sobretudo da própria menina Vitória. Gigi via em Matoso um semelhante e passou a viver com o medo de que tudo o que era atribuído ao garoto escuro chegasse também a ele. Ele se esforçava, então, para imitar os meninos da "baixa" e se afastar de suas origens do musseque. No dia em que a professora lhe pediu uma redação, Gigi sentia-se confiante com seu trabalho, cujo tema era uma figura importante do governo. Ele estava seguro de ter usado os melhores adjetivos e louvado seus feitos. A menina Vitória, no entanto, não titubeou em humilhar Gigi: "com que então pretende brincar comigo...?" O problema identificado pela professora era o tratamento, já que Gigi havia usado o pronome "tu" ao se referir ao governante. A acusação foi implacável: "Ouve lá... tu julgas que ele anda sujo e roto como tu, e como funje na sanzala...?" À dor e à tristeza de Gigi se juntava a dúvida: por que logo a menina Vitória, filha de negra e com “carapinha”, sentia o desejo de humilhá-lo? Sua reação vale ser descrita na íntegra: “Os seus músculos crisparam-se e o caderno começou a amarrotar-se-lhe nas mãos. Depois mal sentiu a violência da palmatória. Só nas faces a queimadura viva da humilhação, só nos ombros a responsabilidade da sua condição que ele não tinha culpa, mas que queria aceitar mesmo dolorosa como as pulsações que lhe ressoavam nas palmas das mãos inchadas. E na carteira chorou. Chorou de raiva, da dor que lhe nascia da piedade dos colegas e da vergonha de não poder esconder a sua angústia, com os olhos secos, enxutos, e orgulhosamente raiados de sangue, como os do Matoso."

O conto, embora esteja na convenção da ficcionalidade, anuncia uma escola que foi pensada para os portugueses e uma sociedade em que se juntar aos brancos era a única possibilidade de ascensão. 


\section{6- Leitor e leitura}

O cenário evocado, em que vemos um número irrisório de pessoas alfabetizadas, um sistema escolar que poucos acessavam e publicações que circulavam de maneira restrita, de fato não sugere a existência de grande número de leitores em Angola. Paradoxalmente, contudo, identificamos diversas instituições indicativas da existência de redes de feitura e distribuição de livros que, apesar de precárias e voltadas a um público restrito, atuavam no território. Além da primeira biblioteca pública do país, datada de 1873, podemos citar dois outros exemplos de instituições literárias que dependiam de leitores: a Livraria Lello ${ }^{12}$, que até agosto de 2015 possuía filial em Luanda, e a Biblioteca Municipal de Nova Lisboa (hoje Huambo). Ambas divulgaram anúncios publicitários do primeiro Boletim Cultural do Huambo, publicação dos Serviços Culturais do Município de Nova Lisboa, que circulou em 1948. A Lello se afirma como "a maior organização livreira da colónia" (Anexo A), enquanto a biblioteca enumera as publicações disponíveis na sede dos Serviços Culturais, oferecendo uma ligeira ideia do acesso possível ao impresso no período, com largo destaque para os jornais e revistas (Anexo B).

Esses serviços, no entanto, buscavam sobretudo atender aos portugueses que viviam na colônia. Pires Laranjeira lembra que a população negra quase não lia jornais e muito menos textos literários, sendo impraticável pensar, nessa primeira metade do século XX, em um público leitor, "muito menos num público formado num gosto africano". Algumas das instituições fundamentais que faziam girar a literatura, como a crítica literária ou a universidade, eram inexistentes. E mesmo havendo criação e circulação de textos de maneira mais efetiva a partir de 1945, ela era "diminuta e descontínua".

Neste panorama, a literatura faz emergir um possível leitor da obra de Uanhenga Xitu, nos oferecendo uma ideia de como se dava a relação entre o angolano negro ou assimilado e o texto. O protagonista Tamoda, em livro datado de 1974, é um homem de origem rural que trabalha durante muitos anos na cidade, prestando serviços a pessoas de nível social mais elevado. Ele "estudava nas horas vagas, com os filhos dos patrões e com os criados do vizinho do patrão. Assim conseguiu aprender a fazer um bilhete e

\footnotetext{
${ }^{12}$ Com sede na cidade do Porto, em Portugal, a Livraria Lello e Irmão, também conhecida como Livraria Chardron, remonta sua fundação ao século XIX. Possuía filiais em Luanda, Lobito e Nova Lisboa, atual Huambo.
} 
uma cartinha que se compreendia" (XITU, 1977, p. 9). Quando, já adulto, volta a sua sanzala, levando consigo "muitos romances velhos, entre eles um dicionário usado e já carcomido, algumas folhas soltas de dicionários, cadernos garatujados com muito vocabulário, um livro de 'Como se escrevem cartas de amor', outro de 'Manual de correspondência familiar' e alguns volumes de leis" (p. 10). Repleto de ironia, o narrador nos conta que "o novo intelectual, no meio de uma sanzala em que quase todos os seus habitantes falavam quimbundo e só em casos especiais usavam o português, achou-se uma sumidade da língua de Camões" (p. 10). Tem-se assim sequência uma série de peripécias envolvendo a maneira como Tamoda se apropria da língua portuguesa, usando vocabulário rebuscado e incompreensível para seduzir jovens alunos que o veem como mestre e para tentar se diferenciar, pelo manejo do idioma, do restante da comunidade. O texto de Uanhenga Xitu nos apresenta um cenário em que poucos têm acesso aos livros e mesmo aqueles que tiveram a chance de frequentar a escola revelam precariedade no trato com o português, pois suas habilidades são suficientes apenas para redigir um bilhete. A posse do livro e da língua, no entanto, representava para alguns, para aqueles que queriam ascender na sociedade colonial, um bem inestimável. Para outros, no entanto, era motivo de pilhéria. O leitor corrente, de qualquer maneira, era figura escassa na sociedade de então, que não tinha condições de decodificar um livro, tampouco uma pessoa que dele se valesse.

O escritor Pepetela parece certeiro ao afirmar que quem lia os autores angolanos nesse início de produção eram seus próprios pares. Escritores se dividiam entre escrever e ler, na enorme tarefa de tentar impulsionar a incipiente literatura angolana. Esse círculo fechado, do qual poucos faziam parte, é o que caracteriza também o início da produção literária em São Paulo, já descrita aqui por Antonio Candido.

O depoimento do historiador Alberto Oliveira Pinto, quando indagado sobre quem lia os livros angolanos nesse período, oferece uma resposta inusitada, mas que nos põe a pensar: de acordo com ele, a PIDE, a polícia portuguesa, era a maior leitora dos autores angolanos. Preocupada com a circulação de "ideias terroristas", a PIDE teria lido com mais interesse e profusão que o parco público local os autores angolanos que acalentavam um projeto de literatura local (entrevista concedida pessoalmente a Ligia Micas em 26 de janeiro de 2015).

Esse projeto forjado nas décadas de 50 e 60, imbuído do desejo de escrever para um homem angolano, tinha outras nuances que nem sempre facilitaram a aproximação com os leitores locais. As inovações estéticas de Luandino Vieira, por exemplo, que de 
alguma maneira se apropriavam da oralidade angolana e das narrativas locais para uma recriação da linguagem, e que portanto teriam evocado um estreitamento com o público, não criou uma imediata recepção. Esse avanço da linguagem, conforme relata Luandino, correspondia a uma radicalidade das propostas dos escritores necessária naquele momento, de luta pela independência política. O objetivo dessa escrita era mais falar aos portugueses que aos angolanos, de maneira que aqueles compreendessem que era possível uma literatura feita na língua portuguesa, mas que os próprios portugueses não se reconhecessem nela, estranhando o texto. Era preciso demarcar uma diferença cultural que se refletiria numa autonomia política.

Nessas décadas de criação e afirmação de uma literatura angolana, portanto, o leitor não está na ordem do dia. Ou ao menos o leitor comum. A prioridade, que nos sugerem essas situações e falas, era consolidar as instâncias de produção e fazer da literatura instrumento de uma política que desembocaria na independência. A formação de leitores, talvez, seria um objetivo posterior. 


\section{3 - UEA E INALD: INSTÂNCIAS DE PRODUÇÃO}

"Assim, quando se chegou à independência, os que vieram dos campos de concentração, os que vieram da guerrilha, os que estavam na clandestinidade e os que estavam abertamente na colônia juntaram-se todos para fazer a União dos Escritores, e foi assim que nasceu a União dos Escritores, no dia 10 de dezembro de 1975. É a primeira instituição criada em Angola independente depois da tomada de posse do governo. Não é a primeira instituição cultural. É a primeira instituição. Diário da República, pode consultar e ver se corresponde à minha memória".

A afirmação que abre este capítulo, e que não se furta de um certo orgulho, é do escritor Luandino Vieira, que me recebeu na sede de sua editora Nóssomos em Vila Nova de Cerveira, Portugal quase Espanha, em um 04 de fevereiro, dia "feriadíssimo"13 para ele. Luandino dirigiu a União dos Escritores Angolanos (UEA) ${ }^{14}$ em duas gestões, de 1975 a 1980 e de 1985 a 1992, e sua fala indica a importância da instituição na nova nação. Que país é este cuja primeira organização a ganhar registro é oriunda do campo literário? A pergunta, me parece, deve ocorrer a muitos e oferece, mais do que uma pista, uma resposta contundente acerca do papel que a literatura desempenhou em Angola tanto no processo de independência quanto nos anos que se seguiram.

Esta é a instituição, portanto, que examinaremos neste momento. Se no capítulo anterior buscamos reconstruir o panorama dos anos que antecederam a independência, mapeando os principais elementos da paisagem literária angolana - escritores, leitores, textos, movimentos, instituições -, agora nos deteremos na análise da UEA, que claramente desponta como uma das protagonistas da literatura de Angola, entendida aqui, de acordo com o explicitado no primeiro capítulo, como sistema e, portanto, abarcando instituições que estão além de autores e textos.

Essa análise será complementada pela observação de outra instituição que, juntamente com a UEA, foi responsável não apenas por grande parte da edição de livros que circulou em Angola em determinado período, mas também por múltiplas atividades

\footnotetext{
${ }^{13}$ Foi em 04 de fevereiro de 1961 que teve início a luta armada em Angola contra o regime colonialista. O país festeja até hoje a data como feriado da "Luta Armada de Libertação Nacional".

${ }^{14}$ A União dos Escritores Angolanos será denominada ao longo do texto como UEA ou União.
} 
envolvendo a literatura no país. O Instituto Nacional do Livro e do Disco (Inald), fundado em 1977 em Luanda (de 77 a 79 designava-se apenas Instituto Nacional do Livro), foi criado com o intuito de promover a literatura e a leitura, tendo como principais vias a edição de livros e a realização de concursos literários. O Inald, ligado ao Ministério da Cultura, foi percebido como outro ator destacado no cenário de produção de livros no país quando as pesquisas em torno da UEA já caminhavam e foi definitivamente incluído na dissertação, ainda que com menos destaque, pela presença constante nos discursos daqueles que nos falaram sobre a União.

Ao analisarmos as práticas da UEA e do Inald, o objetivo é nos aprofundarmos no projeto literário angolano, em grande parte conduzido por essas instituições, que funcionaram como editoras e promotoras da literatura nos anos que se seguiram à independência.

Se a leitura, como nos alerta Chartier, é resultado deste encontro entre as determinações do livro e a liberdade do leitor, nossa proposta é observar essas instâncias de produção buscando cumprir dois propósitos: mapear um projeto literário levado a cabo por atores centrais e oficiais no sistema angolano, que contribuíram para estabelecer um cânone de autores e obras, e entender qual leitor estava no horizonte desse projeto, ou qual ele pretendia formar. No último capítulo, buscaremos finalmente entender como esse projeto ecoou nos leitores angolanos.

Tanto a UEA quanto o Inald, vale ressaltar, seguem atuantes na Angola de hoje. Nosso foco, no entanto, está no período que vai de 1975, ano da independência, até 1991, quando o país passa por mudanças significativas que sem dúvida impactam as formas de feitura e circulação do livro e, portanto, de leitura em Angola.

Durante este período são dois os fatos inerentes ao contexto angolano de que não devemos descuidar: o governo que assumiu o país se pretendia marxista-leninista ${ }^{15}$ o que representou uma forte atuação do Estado em distintas instâncias; e Angola vivenciava uma guerra civil entre os movimentos que, tendo lutado pela independência do país, divergiam sobre os rumos da nova nação ${ }^{16}$. Essa guerra teve início ainda em

\footnotetext{
${ }^{15}$ O primeiro congresso do MPLA, ocorrido em dezembro de 1977, foi a ocasião em que o movimento se constitui em partido (passa a designar-se MPLA-PT) e aprova uma orientação marxista-leninista.

16 Como resultado de anos de luta anticolonial, a independência de Angola foi conquistada. Após a Revolução dos Cravos, ocorrida em 1974, foi possível abrir negociação com o governo português, de maneira que os três movimentos que lutaram pela nova nação - o MPLA, a União Nacional para a Independência Total de Angola (UNITA) e a Frente Nacional de Libertação de Angola (FNLA) formaram um governo de transição determinado pelos Acordos de Alvor, que não foram aplicados devido às numerosas diferenças entre os grupos. Assim, a 11 de novembro de 1975, o MPLA proclamava em Luanda a República Popular de Angola, enquanto a FNLA proclamava a independência em Ambriz e a
} 
1975 e se prolongou até o ano de 2002, somando cerca de 1,5 milhão de mortos e provocando o deslocamento de 4 milhões de pessoas (Balanço de Implementação da $2^{\mathrm{a}}$ Reforma Educativa em Angola, 2011, p. 8).

O ano de 1991 marca uma tentativa de paz $^{17}$ com a assinatura do Acordo de Bicesse entre as duas partes do conflito - o MPLA e a União Nacional para a Independência Total de Angola (UNITA) -, o que foi possível pelo fim da Guerra Fria. Tratava-se de um acordo no qual a UNITA reconhecia o governo e o presidente angolanos, enquanto o governo angolano, por sua vez, reconhecia o Protocolo de Washington, de dezembro de 1990, sobre multipartidarismo e realização de eleições; o acordo de cessar-fogo com normas para a desmobilização e desmilitarização; e o protocolo sobre a transição, com a criação de uma comissão político-militar conjunta, que previa a extinção dos exércitos em beligerância e a criação das Forças Armadas Angolanas (FAA).

$\mathrm{O}$ acordo ocasionou transformações em distintas áreas, preparando o país para o multipartidarismo e as eleições democráticas que aconteceram no ano seguinte. Entre essas transformações está uma que diz respeito diretamente ao tema deste trabalho: a abertura econômica do mercado angolano decorrente do abandono da diretiva marxistaleninista que, entre outros aspectos, impactou o setor de comunicação social, então liberado para a iniciativa privada, o que permitiu a participação de outros jogadores no sistema literário do país, como jornais e editoras. A UEA e o Inald, portanto, deixam de atuar praticamente sozinhos na edição de livros no país. No período analisado, no entanto, são dois grandes protagonistas que atuam num cenário de limitações impostas pela guerra.

Para proceder a essa história da leitura e nos auxiliar nessa revisitação a um período distante em mais de 30 anos, foram consultados para este trabalho atores que estiveram ou estão profundamente envolvidos com as instituições a serem examinadas, que são instâncias de produção literária, a grande maioria deles escritores angolanos. Foram concedidas entrevistas exclusivas para este trabalho, a partir de um roteiro aberto de perguntas que buscava, pela memória desses protagonistas, entender as motivações,

UNITA decretava no Huambo a criação da República Democrática de Angola, dando vazão a governos paralelos. Os países, aí incluído Portugal, acabaram por reconhecer como legítimo o governo do MPLA. Com o enfraquecimento da FNLA, será a UNITA, fortalecida por alianças com países ocidentais e o regime do apartheid da África do Sul, que levará uma longa guerra de guerrilha contra o governo de Angola.

17 A guerra foi reiniciada após as tumultuadas eleições de setembro de 1992, acusadas de fraudulentas pela UNITA. A paz só foi alcançada definitivamente em 2002, ano da morte do líder da UNITA, Jonas Savimbi (PINTO, 2015, p. 766). 
funcionamento e ações da UEA e do Inald. Recorremos, então, a quem vivenciou o período em questão e que poderia falar de dentro das instituições, como é o caso do escritor Luandino Vieira, que foi por dois mandatos secretário geral da UEA, e dos escritores Boaventura Cardoso e António Fonseca, que presidiram o Inald nos anos que pretendemos abarcar. Complementa as fontes principais deste trabalho o escritor Pepetela, na altura vice-ministro da Educação e hoje presidente da UEA. O atual secretário geral da União, Carmo Neto, encerra a relação das fontes sobre cujas informações se fundamenta este capítulo.

Outras pessoas foram entrevistadas tendo em vista também a feitura deste trabalho, oferecendo em seus depoimentos informações, pistas, recordações, apontamentos. As entrevistas não serão usadas de maneira central no trabalho, mas, sendo evocadas ou não, fazem parte da trilha percorrida e em muito contribuíram para a compreensão do momento histórico vivido por Angola. A escolha das fontes buscou abarcar as diversas instâncias envolvidas com o fazer e a crítica literária, privilegiando, além de escritores, as instituições editora e universidade, assim como a fundamental colaboração de um historiador.

Abaixo, um breve perfil de todos os entrevistados, por ordem alfabética:

Alberto Oliveira Pinto - filho de portugueses, nasceu em Angola e lá viveu até os 14 anos. Dedicou seu mestrado e doutorado à história de África. Membro da União dos Escritores Angolanos, publicou também diversos romances, entre eles Eu à sombra da figueira da Índia, Concerto na nespereira, O saco dos livros, Mazanga e Travessa do rosário. Em 2015 lançou História de Angola - Da pré-história ao início do século XXI. Foi entrevistado pessoalmente em janeiro de 2015, em Lisboa.

António Fonseca - escritor, professor universitário e com larga atuação no campo cultural, António Fonseca é hoje assessor do Ministério da Cultura. Membro da União dos Escritores Angolanos, dirigiu o Inald entre 1983 a 1994. Foi entrevistado, por e-mail, em janeiro de 2017.

Artur Carlos Maurício Pestana dos Santos (Pepetela) - autor de diversos romances, grande parte deles envolvendo a história de Angola, Pepetela participou da guerrilha contra Portugal, atuando nas frentes Leste e de Cabinda pelo MPLA. Membro fundador da União dos Escritores Angolanos, foi vice-ministro da Educação de 1976 a 
1982 e hoje preside a UEA. Concedeu-me entrevista por e-mail durante o mês de janeiro de 2017.

Boaventura Cardoso - autor de obras como Dizanga Dia Muenhu, A morte do velho Kipacaça e Mãe Materno Mar, Boaventura é membro fundador da UEA e ocupou diversos cargos públicos na nação independente, dentre eles o de Ministro da Cultura e de Governador da Província de Malange. Dirigiu o Inald entre 1977 e 1981 . Concedeume entrevista em dois momentos: em março de 2013 e em janeiro de 2017.

Carmo Neto - o atual secretário-geral da UEA é jurista e jornalista, tendo também se dedicado à literatura, com obras como A forja e Mahézu. Conversas foram iniciadas com Carmo Neto em 2015 e mantidas ao longo dos últimos meses dessa pesquisa.

Francisco Topa - professor português, hoje leciona na Faculdade de Letras da Universidade do Porto. Sua investigação abrange as literaturas africanas de língua portuguesa. Organizou em 2014 o livro Luuanda há 50 anos, sobre os acontecimentos em torno da premiação da obra de Luandino Vieira pela Sociedade Portuguesa de Escritores. Foi entrevistado pessoalmente em janeiro de 2015, no Porto.

Jacques Arlindo - escritor e cronista angolano, é sócio fundador da Associação Cultural Recreativa Chá de Caxinde, criada em 1989, com sede em Luanda. Depois de uma década operando como entidade cultural, a Chá criou um selo editorial, tendo publicado clássicos da literatura angolana. Jacques é o atual presidente da Chá de Caxinde. Foi entrevistado por e-mail em junho de 2013.

José Luandino Vieira - escritor consagrado, Luandino nasceu português e tornou-se cidadão angolano. Participou da luta pela independência de Angola e exerceu diversos cargos públicos na nova nação. Foi secretário geral da União dos Escritores Angolanos nos períodos de 1975 a 1980 e de 1985 a 1992. Publicou, entre livros de contos, romances e novelas, A cidade e a infância, Luuanda, A vida verdadeira de Domingos Xavier, Nós, os do Makulusu e No antigamente, na vida, dentre outras obras. Foi entrevistado pessoalmente em 04 de fevereiro de 2015 em Vila Nova de Cerveira, Portugal. 
Leonel Cosme - jornalista e escritor português que viveu décadas em Angola, foi co-fundador da editora Publicações Imbondeiro na então cidade de Sá da Bandeira, hoje Lubango. Foi entrevistado por e-mail em maio de 2015.

Zeferino Coelho - o editor português trabalha na Caminho, hoje do grupo Leya, que desde 1975 teve grande atuação na publicação de escritores africanos, sobretudo lusófonos, em Portugal. Autores como Craveirinha, Germano Almeida e Luandino Vieira integram o catálogo da editora, que também criou a Editorial Nzila, sediada em Angola. Foi entrevistado pessoalmente em janeiro de 2015, em Lisboa.

Zetho Cunha Gonçalves - nascido em Angola, o poeta e escritor de literatura infanto-juvenil vive hoje em Portugal. Publicou cerca de 30 livros e dedica-se inteiramente à poesia. É organizador de diversas antologias, entre elas 35 poemas para 35 anos de independência. Foi entrevistado pessoalmente em janeiro de 2015, em Lisboa.

A pesquisa de acervo em livros, jornais e outros documentos da época também foi realizada - fisicamente em bibliotecas públicas e pessoais de São Paulo e de Lisboa e de maneira virtual em arquivos de Luanda -, mas em condições de considerável limitação. É conhecida a realidade de países de recente passado colonial e subsequente guerra civil, cujo patrimônio por um lado foi em muito dilapidado e, por outro, não está organizado de maneira centralizada e de fácil acesso ao pesquisador. Luandino lembra ainda que a União passou por sucessivos assaltos e grandes chuvas, o que contribuiu para a perda de material. Já Carmo Neto é taxativo sobre alguns números da UEA do período em questão: "não temos, em nossa posse, esses dados". Em uma conversa sobre a prevalência do romance histórico em Angola, Luandino declara que "há uma falha muito grande" no país no que tange ao ensino e à pesquisa em história na universidade, de maneira que, e isso nos toca, "deixou-se morrer muita gente sem recolher testemunho".

Em razão de todas essas dificuldades, este trabalho é também uma tentativa de oferecer uma contribuição nessa seara, fazendo da nossa escuta um sentido privilegiado para que resista a memória dos agentes que participaram ativamente desse processo. Como nos ensina Ecléa Bosi em seu sensível Memória e Sociedade - lembranças de velhos, "uma pesquisa é um compromisso afetivo. Um trabalho ombro a ombro com o 
sujeito da pesquisa" (BOSI, 1994, p. 38). Deixemos, então, falar os atores angolanos, para que pelos fios da memória possamos, em alguma medida, dar continuidade a um "colar de contas amigadas"18 forjado nos tempos do antigamente.

\section{1 - União dos Escritores Angolanos}

\subsection{1 - Fundação, papel e relação com governo}

A data de fundação da União dos Escritores Angolanos é 10 de dezembro de 1975, o que faz dela a primeira instituição da nova República Popular de Angola, cuja independência data de 11 de novembro do mesmo ano. Na fala de Russel Hamilton, a proclamação da UEA “apenas um mês após a independência e num clima civil e militar ainda instável, é testemunho vivo do papel que o escritor e a literatura desempenhariam na nova sociedade em formação" (HAMILTON, 1975, p. 168).

A União foi proclamada e se instalou no antigo Cinema Restauração ${ }^{19}$, hoje Assembleia Nacional, em Luanda, com 32 escritores entre seus membros fundadores (Anexo C). Ao analisarmos seu manifesto de fundação, vemos como a UEA reafirma os valores que os movimentos literários vinham acalentando desde a década de 50 , de maneira a atribuir à literatura e aos escritores um papel que extrapola o da expressão artística:

No momento em que nosso povo acaba de assumir a plena responsabilidade do seu futuro como nação livre e soberana, os escritores angolanos permanecem na vanguarda, face às grandes tarefas de libertação e reconstrução nacionais. (...) A história da nossa literatura é testemunho de gerações de escritores que souberam, na sua época, dinamizar o processo da nossa libertação exprimindo os anseios profundos do nosso povo, particularmente $\mathrm{o}$ das suas camadas mais exploradas. A literatura angolana escrita surge assim não como simples necessidade estética, mas como arma de combate pela afirmação do homem angolano (ERVEDOSA, 1985, p.122).

\footnotetext{
${ }^{18}$ A expressão, tão bonita, foi extraída de romance de Luandino Vieira e precisamente usada no livro $A$ kinda e a misanga, coletânea de ensaios de pesquisadores brasileiros sobre a literatura angolana organizada por Rita Chaves, Tânia Celestino de Macêdo e Rejane Vecchia. O livro, sugestão de Luandino, opera como uma ponte fraterna entre Brasil e Angola.

${ }^{1919}$ De acordo com o historiador Alberto Oliveira Pinto, o aumento da população branca em Luanda durante a década de 1940 resultou na edificação de diversos novos prédios, entre eles os que abrigavam espetáculos. O Cinema Restauração é um desses espaços destinados a servir bairros "luxuosos", entre o Parque Heróis de Chaves e o Bairro Azul. Construído em 1948, foi também sede do Palácio dos Congressos e da Assembleia Nacional (PINTO, 2015, p. 682).
} 
Já vimos, no capítulo anterior, de que maneira a palavra foi usada como "arma de combate" no processo de luta por uma Angola independente. Na nova nação, a UEA defende uma continuidade da função emancipatória da literatura.

Embora no artigo terceiro de seu estatuto (Anexo D) a União defenda como princípios fundamentais a "independência intelectual e orgânica" e a "liberdade criativa", ela preconiza a estreita vinculação de seus escritores à cultura angolana. Isso fica claro no correr de suas finalidades, cujas três primeiras são: representar os escritores angolanos membros da UEA; promover a defesa da cultura angolana como patrimônio da Nação; e estimular os trabalhos tendentes a aprofundar o estudo das tradições culturais do Povo Angolano.

$\mathrm{Na}$ esteira desses ideais, é icônico que o primeiro presidente de Angola, Agostinho Neto, tenha sido também o primeiro presidente da mesa da Assembleia Geral da UEA, que é a instância máxima da organização. Médico formado em Portugal, tendo estudado primeiro em Coimbra e depois em Lisboa, Neto assumiu a presidência do MPLA em 1963, constituindo-se como líder "carismático e incontestado" (PINTO, 2015, p. 699). A trajetória de Neto é marcada pela atuação política e intelectual, em muito forjada nos tempos em que frequentou a Casa dos Estudantes do Império, espaço que possibilitou a reunião de estudantes oriundos das colônias e que propiciou os primeiros passos de movimentos de libertação das antigas colônias portuguesas na África ${ }^{20}$. Com obra publicada em diversos países, Neto tem uma poesia que redesenha os contornos de uma Angola livre. Ela se inicia com o livro Náusea, de 1952, e encontra seu ápice em Sagrada Esperança, de 1974.

Luandino traz uma visão particular de Agostinho Neto, afirmando que ele não quis ser o primeiro a assinar a ata de proclamação da União, mas indicou Antonio Jacinto $^{21}$, por ser "muito melhor poeta" que ele. "Diga lá que é uma ordem do presidente da república”, conta Luandino, oferecendo o tom do que foi, em sua opinião,

\footnotetext{
${ }^{20}$ A Casa dos Estudantes do Império funcionou em Lisboa, com delegações no Porto e em Coimbra, de 1944 a 1965. Embora tenha surgido na ditadura salazarista por sugestão do Ministro das Colônias, com o objetivo de reunir em uma só associação os jovens "ultramarinos" que estudavam na metrópole, "a Casa cedo subverteu as expectativas oficiais de um corpo obediente e alinhado com a ideologia imperial". Não à toa foi encerrada pela PIDE, a polícia portuguesa. Foi, assim, ponto de encontro e fabulação de ideias de jovens que vinham de diferentes países, muitos deles envolvidos nas lutas de libertação das então colônias portuguesas, alguns dos quais em posições de destaque como militantes e dirigentes, outros como participantes na construção dos novos países africanos independentes. (http://casacomum.org/cc/arquivos?set=e_10883, acessado em 03 de fevereiro de 2017)

${ }^{21}$ António Jacinto, premiado poeta angolano, militou pelo MPLA e assumiu o posto de Ministro da Cultura após a independência, de 1975 até 1978. É de sua autoria a conhecida obra Carta de um contratado, poesia usada como epígrafe neste trabalho e que mereceu o seguinte comentário de Luandino: "Carta de um contratado é um programa literário".
} 
a UEA dos primeiros anos, uma instituição que cumpriu não de maneira obrigatória, mas quase missionária, um papel fundamental no desenvolvimento do país que emergia.

A União, desde sua fundação, fez mais que representar seus membros associados. Suas atividades foram ampliadas, tendo ela operado como uma espécie de braço da cultura do governo em vigor. Se observarmos outras ex-colônias portuguesas em África, como Moçambique e Cabo Verde, percebemos que nessas nações os escritores se reuniram em torno de uma associação - Associação dos Escritores Moçambicanos (AEMO), de 1982, e Associação de Escritores de Cabo Verde (AEC), de 1989 -, e que elas surgiram posteriormente à instituição angolana. Já a União, instituição construída nos mesmos moldes da União Nacional dos Trabalhadores de Angola (UNTA), possui esse caráter mais amplo, em que a própria denominação indica uma atuação que não se restringe aos interesses de seus autores, mas projeta a importância do setor que representa - o literário - sobre a sociedade.

Como nos conta Luandino, desde o início a UEA assumiu um papel editorial, mas não foi por deliberação de sua direção, e sim

porque houve um movimento intenso, mesmo programático, de educação/cultura. (...) De início nem havia Secretaria de Estado de Cultura, havia Ministério da Educação e Cultura. Portanto o grande movimento foi passar dos $98 \%$ de analfabetos e para eliminar isso, além da vertente do ensino, que competia ao Ministério da Educação, a Cultura foi chamada também, neste caso, a produzir materiais culturais e literários para ir respaldando o avanço da alfabetização no país. (...) Portanto este foi o caminho que foi seguido pela União dos Escritores, não como uma determinação programática das direções da União dos Escritores, mas porque o movimento histórico daquelas décadas, até 1990, justificava que os escritores, não só a sua produção estava sendo influenciada por esse momento, mas também a edição foi influenciada. Agora, era preciso material literário para acompanhar o esforço que o país fazia no sentido de passar de $98 \%$ para $75 \%$, como se passou. Com as campanhas de alfabetização, com todos os erros dos primeiros anos da independência, foi quando se conseguiu isso tudo. Imagina se não tivéssemos errado. Desculpe falar com esse orgulho, porque hoje faz-se uma edição em Luanda - bom, hoje o sistema é outro, as editoras são comerciais, hoje tudo está ligado ao sistema de mercado, ao capitalismo de mercado, à economia de mercado - de 500 exemplares, quando no tempo da União nós fazíamos 5 mil. 
Nesta fala do escritor vemos como num jovem país, ainda carente de instituições e que trilhava o caminho do socialismo, a atividade editorial é assumida por uma entidade que não tem função comercial. Sobressai ainda a informação de que seus produtos, os materiais literários sobre os quais nos conta Luandino, têm como grande destinatário o próprio Estado, que deles se valeu em seus projetos educacionais.

Além desses destacados papéis, de editora e de parceira nos programas governamentais, a União atuou, em linhas gerais, como promotora da literatura angolana não apenas em Angola, mas também em outros países lusófonos. No Brasil, por exemplo, em parceria com a editora Ática, fez circular, na década de 1980, nomes como Jofre Rocha, Arnaldo Santos e Pepetela, dentre outros, na conhecida coleção Autores Africanos, que chegou a 27 volumes.

Para ingressar na União, um autor devia cumprir as exigências que ainda hoje estão em vigor e que são as preconizadas no artigo $6^{\circ}$ de seus Estatutos:

A admissão será pedida por escrito pelo candidato que tenha publicado duas obras e proposta por três membros da União no pleno gozo dos seus direitos. Os candidatos devem apresentar três textos ensaísticos sobre literatura ou cultura angolana. Compete à Comissão Diretiva deliberar sobre a admissão do candidato, a qual deve ser decidida por maioria dos seus membros. Da recusa de admissão podem os proponentes recorrer à Assembleia Geral no prazo de 15 dias a contar da data de recepção do aviso daquela recusa.

Nos dizeres de Pepetela, "tinha de ter uma obra publicada e dois membros da União que o apadrinhassem, segundo os Estatutos. Na prática, era a União que publicava o primeiro livro e depois ele entrava". A necessidade de uma produção textual que exalte os valores angolanos, vale ressaltar, está explicitada nos princípios que regem a entidade.

Instituída a organização, a primeira providência da União foi publicar obras que durante o regime colonial estavam proibidas de circular, como aquelas escritas por Luandino Vieira, Agostinho Neto, António Jacinto e outros nomes da "geração da guerrilha”, como afirma Carmo Neto. Ainda segundo ele, essa prática vigorou até 1991.

Ao fazer um panorama da poesia angolana logo após a independência, a pesquisadora Carmen Tindó Secco também nos fala desta especificidade da União: 
A independência e os anos imediatamente a seguir geraram em Angola uma euforia que contaminou grande parte do povo, dos intelectuais, dos poetas, dos escritores, dos pintores. Os dez primeiros anos após o 11 de novembro de 1975 foram o período em que a poesia e as artes em geral deixaram a clandestinidade assumida durante a luta armada para ocuparem um lugar na reconstrução do país. O movimento editorial cresceu, tendo cabido à União dos Escritores Angolanos, fundada em 10 de dezembro de 1975, um papel de destaque. Isto porque, devido à censura do regime colonial, os poetas, artistas e escritores eram, até então, pouco conhecidos tanto dentro, como fora de Angola. No país, muitos eram lidos em exemplares copiografados, o que impedia uma maior divulgação pública. Grande parte dos poetas se inseria tanto no movimento literário, como nas lutas políticas de independência e na organização do Estado angolano. Agostinho Neto, Costa Andrade, António Cardoso, Jofre Rocha, entre outros, são nomes representativos da poesia revolucionária, nacionalista (SECCO, 2013, p. 10).

Vemos, portanto, como a União, ao dedicar seus primeiros anos a publicar textos que não encontraram lugar no regime colonial, conduz uma primeira e significativa ruptura com o modelo até então vigente de circulação de obras.

Os critérios para a publicação pela União, de acordo com Carmo Neto, contemplavam duas instâncias: a qualidade literária, mas também a promoção de determinadas vozes que não poderiam deixar de ser ouvidas.

Os requisitos eram de dois tipos: por um lado, a excelência da escrita, como o romance Mayombe, de Pepetela, que, embora fizesse a crítica da guerrilha, encerrava em si as qualidades perfeitas de um clássico. Por outro lado, a UEA não pôde, nesse período, deixar de publicar algumas obras sem grande mérito artístico, mas que foram produzidas por ex-guerrilheiros, embora em número muito reduzido.

Essas questões nos remetem a uma realidade inescapável da entidade. A trajetória da UEA e de seus criadores se confunde com a da própria nação. Guerrilheiros, intelectuais, políticos, poetas, governantes, escritores. São muitos os nomes que assumem todas essas facetas na Angola de então, tendo participado da luta de libertação pelo MPLA, tendo sido membros fundadores da União e sido incumbidos de postos no novo governo. 
Essas condições particulares suscitam uma série de perguntas acerca da autonomia e isenção na relação entre o MPLA e a União. Vejamos o que Luandino nos diz a respeito:

Essas condições históricas que deram aos escritores angolanos esse papel de inconfidência que deu certo. Não têm culpa nenhuma. Utilizaram o domínio da cultura, da literatura, da poesia para o pouco trabalho político visível que se podia fazer e ao mesmo tempo trabalho clandestino. E quando emergiu o país, eles emergiram. E depois houve logo aquela crise inicial de fuga dos quadros, os que ficaram tiveram que assumir coisas que não sabiam... Eu nunca tinha, nem sabia a palavra "vídeo" quando me fizeram presidente do conselho de administração da televisão. Estava saindo do campo de concentração, não sabia nada. (...) Essas foram decisões historicamente acertadas. O que íamos dizer? Desculpa, não queremos nada, andamos esses anos todos numa luta de libertação e afinal...

O que Luandino aponta é que em uma situação limite como a da construção de uma nação, em meio a um cenário de dificuldades e desafios, como foi a ausência de pessoal qualificado, do escritor é exigido um papel que está além de sua atuação literária. A esse chamamento, defende Luandino, os autores, conscientes de sua missão, não poderiam se furtar.

Já Carmo Neto reivindica uma relativa autonomia da União, sem deixar de citar a contradição ali existente:

Dentro da UEA existia um ambiente de relativa autonomia em relação ao controle pela parte do Estado, constituindo-se como uma associação realmente independente de produção e publicação literária. Devido a este estatuto independente, a UEA foi fundamental no desenvolvimento cultural em Angola, tendo liderado o esforço de reestruturação do campo literário, tornando-se numa organização dirigida por intelectuais que representava legitimamente a grande maioria dos escritores angolanos, ao mesmo tempo que defendia os interesses da revolução. Era, por isso, uma contradição onde coexistiam o controle político e a autonomia literária, impedindo, de certa forma, a instrumentalização política dos escritores e da literatura em Angola.

O que hoje, 40 anos depois, parece inevitável perguntar é o quanto essa relação, sem dúvida próxima entre Estado e instância literária, impactou a literatura de Angola. Russel Hamilton já alertava que, nos anos que rondaram a independência, "o controlo dos meios literários estava certamente nos intervenientes e simpatizantes desse grupo 
nacionalista (o MPLA)", enquanto não havia um "número apreciável de escritores ligado à FNLA e à UNITA"22 (HAMILTON, 1975, p. 165).

O pesquisador Nelson Pestana, em um instigante texto sobre as dinâmicas da sociedade civil em Angola, reconstrói esse caminho da União. Ele relembra o fato, eternizado em diversos discursos, de que o líder do MPLA, Agostinho Neto, apesar de, no campo político ser um "defensor acérrimo da ditadura típica do 'socialismo real”, no campo literário recusou o realismo socialista de inspiração soviética, reivindicando uma liberdade criativa para as instâncias artísticas ${ }^{23}$.

Esta contradição permitiu a separação do campo político do campo cultural e a formação no interior deste de um espaço de relativa liberdade, o que é significativo para um regime onde, sobretudo na sua primeira fase, o uso público da razão por pessoas privadas era coisa subversiva mesmo no domínio meramente cultural. Isto não quer dizer, no entanto, que o partido único não procurou estruturar o campo cultural propondo-se 'desenvolver a cultura de massas', segundo os princípios do marxismo-leninismo, considerada 'valor primordial na educação do povo'. Claro que o poder vai procurar controlar o espaço cultural, até ao mais pequeno detalhe, ao fazer barragem à produção intelectual daqueles que se situam à margem da ordem revolucionária ou a ela se opõem. Os intelectuais vão posicionar-se em relação ao poder e uns em relação aos outros, não em função de razões próprias ao campo intelectual mas por razões do campo político. As razões culturais, mesmo quando coexistem com as razões políticas, somente se irão impor mais tarde (PESTANA, 2003, p. 9).

Pestana evoca como exemplo para ilustrar seu argumento de que existiria o desejo de controle convivendo com a vontade de autonomia por parte dos intelectuais fato ocorrido logo em 1976 e que envolve o poeta Viriato da Cruz, referência das letras angolanas, mas dissidente político do MPLA. Quando o Ministério da Educação e

\footnotetext{
${ }^{22}$ De fato, foram pouquíssimas as obras publicadas por autores que militaram fora do MPLA. O líder da UNITA, Jonas Savimbi, por exemplo, publicou um único livro de poemas - Quando a terra voltar a sorrir um dia -, em 1985, editado pela Perspectivas e Realidades, de Lisboa. Já o jornalista Sousa Jamba, que atuou como repórter da UNITA e é reconhecido como escritor, iniciou suas publicações apenas em 1990. Seu primeiro livro - Patriotas - é editado em língua portuguesa em 1991, pela Cotovia, também de Portugal.

${ }^{23}$ Apesar de ser recorrente essa afirmação acerca da liberdade criativa defendida por Agostinho Neto, também encontramos momentos em que exalta uma literatura afinada aos interesses do Estado, como neste fragmento de discurso no ato de posse como Presidente da Assembleia Geral da UEA, em 24 de outubro de 1977: "A literatura, na Angola independente e caminhando para uma forma superior de organização social - o Socialismo -, tem de, necessariamente, refletir essa nova situação" (Caderno Especial Lavra \& Oficina, 1979, p. 9).
} 
Cultura decide incluir seu nome na seleção de textos de um material de ensino escolar, encontrou ferrenha oposição do Bureau Político do MPLA.

Para o regime este grande poeta da angolanidade e modernidade que já havia perecido no exílio em 1973, era um poeta maldito, não pelo seu discurso literário mas pelas suas posições políticas no interior do movimento de libertação nacional, nos anos 60 e, nomeadamente, pela sua oposição ao golpe de força que conduziu Agostinho Neto à presidência do MPLA em 1963. A intenção era de fazer pagar a título póstumo ao poeta Viriato da Cruz os dissabores do homem político que ele foi. Mas apesar desta oposição, António Jacinto que era um revolucionário libertário e que se assumia mais como poeta do que como Ministro, conseguiu junto de Agostinho Neto, senhor de todas as engrenagens do partido-Estado, a 'autorização' para o incluir na sobredita selecta literária (PESTANA, 2003, p. 10).

A União, para Pestana, traduz esse jogo de forças, pois ela, ao mesmo tempo em que busca liderar este esforço de estruturação do campo literário, "definindo-se como a organização dos escritores que defendiam a revolução", vai pleitear a legitimidade de representar todos os escritores angolanos.

A União de Escritores Angolanos era o lugar onde evoluía esta contradição entre a 'autonomia literária' e 'controle político': ao mesmo tempo que proporcionava uma relativa autonomia do espaço literário, nomeadamente face ao controlo do partido único e do Estado, permitiu esforços redobrados das elites políticas com vista à instrumentalização política da literatura e dos escritores. Enquanto o poder político progredia em direcção à radicalização do regime de 'ditadura democrática revolucionária', como etapa de transição para o socialismo científico (considerado objectivo estratégico do MPLA para a sociedade angolana após a III ${ }^{\mathrm{a}}$ Reunião Plenária do seu Comité Central, em Dezembro 1976), a União de Escritores Angolanos recusava o realismo socialista como opção literária oficial (PESTANA, 2003, p. 11).

Esta visão não é unânime, pois encontramos autores que veem a instituição como um bom exemplo de autonomia em um país em que o Estado possui largos tentáculos. Para o historiador Alberto Oliveira Pinto

À partida, a Angola de Agostinho Neto teve o mérito de privilegiar o conhecimento intelectual em detrimento do hedonismo capitalista do lucro comercial. Uma das provas paradigmáticas é a União dos Escritores Angolanos (UEA), proclamada ainda a 10 de dezembro de 1975 pelo próprio 
Agostinho Neto - que foi o seu primeiro presidente da Assembleia-Geral, com José Luandino Vieira como secretáriogeral - e que, até hoje, tem assegurado uma plena autonomia literária em relação ao Estado, prevalecendo como uma instituição interventiva de referência na sociedade angolana (PINTO, 2015, p. 738)

Em que pesem a extrema proximidade entre partido político, governo e União de escritores e a relevância da discussão, esta dissertação não busca averiguar as nuances desses mecanismos nem fazer a crítica de uma possível contaminação, mas sim, lidando com um fato histórico, entender como operava a União e o quão sua produção impactou a literatura de Angola.

\title{
3.1.2 - UEA, a alfabetização e a escola
}

Quando Angola celebrava sua independência, em 1975, menos de $3 \%^{24}$ da população tinha condições de ler um livro. Uma das prioridades do governo foi trabalhar para reverter o quadro, o que foi implantado a partir de amplas campanhas de alfabetização. Como nos conta o escritor Pepetela, vice-ministro da Educação no período de 1976 a 1982:

\begin{abstract}
A campanha de alfabetização começou nas matas, quando estávamos na guerrilha. Adaptamos algumas ideias de Paulo Freire ao manual cubano de 1960. Surgiu então o nosso que se espalhou sobretudo por Cabinda e pela Frente Leste. Muitos guerrilheiros e mulheres foram alfabetizados nessas condições difíceis, onde não havia papel ou lápis (escreviam na areia, muitas vezes) e um pedaço de mandioca branca servia para escrever no quadro. Depois da independência, aproveitamos essa experiência, adaptamos os manuais às novas condições, pois o inimigo já não era o mesmo, e espalhamos por todo o país. A alfabetização sempre foi uma preocupação grande e acho que tivemos algum sucesso. Claro que as muitas guerras que se seguiram dificultaram essa tarefa. Os alfabetizadores e orientadores antes e depois da independência eram normalmente jovens voluntários, que recebiam cursos para poderem desempenhar as missões.
\end{abstract}

\footnotetext{
24 Os números em torno do analfabetismo em Angola não são precisos à altura da independência. Em 1958 a taxa de analfabetismo entre os negros africanos avaliada pela Unesco era de 97\% (PÉLISSIER \& WHELLER, 2013), mesmo índice citado por Luandino Vieira (o autor fala por vezes em 97\%, por vezes em 98\%). Já o Censo nacional, realizado em 1970, aponta a mesma taxa para os negros, enquanto em 1975 o PNUD-Angola indica que a população analfabeta, aí incluídos todos os habitantes, era de $85 \%$.
} 
Dados apontam que desde que foi lançada, em 22 de novembro de 1976, até os anos 2000, período em que o país ainda vivenciava a guerra civil, a Campanha Nacional de Alfabetização foi responsável por tirar do analfabetismo mais de 2.800 .000 pessoas (NGULUVE, 2006, p. 113).

Se a alfabetização competia ao Ministério da Educação, a área cultural, representada pela UEA, foi convocada para, como afirma Luandino, "produzir materiais culturais e literários para ir respaldando o avanço da alfabetização no país". O que Luandino deixa claro é que este não foi um movimento imposto pelo MPLA, mas algo espontâneo, que respondia a uma tentativa de cumprir aquilo por que se lutou - "a independência política e uma sociedade diferente".

A primeira coisa que estava reconhecida era eliminar o analfabetismo. Como é que os escritores participam disso? Porque brigadistas para andar a ensinar por todas as regiões não faltavam, havia voluntários a mais. Os escritores cumpriram ou tentaram cumprir produzindo os textos.

Para Luandino, isso explica o porquê da literatura dos anos 75 a 85 ainda vir marcada pelas orientações estéticas e pela temática social desenvolvidas nos anos 30, 40 e 50 por nomes como Oscar Ribas, Cordeiro da Matta, Agostinho Neto, Viriato da Cruz, Antonio Jacinto e os "poetas da guerrilha" Costa Andrade e Casimiro Rodrigues, que teriam influenciado os mais jovens.

Além do envolvimento com as campanhas de alfabetização, a União estava afinada com o governo nas definições voltadas para a literatura e material didático utilizado nas escolas. Com a independência, houve gradativamente a implementação de um novo sistema de ensino, formalizado em $1978^{25}$. De acordo com Pepetela, a ideia básica foi criar um ensino novo, "totalmente diferente do colonial" e ligado à realidade

\footnotetext{
${ }^{25}$ Segundo Alberto Kapitango Nguluve, que desenvolveu ampla pesquisa sobre a política educacional angolana, "o MPLA, de orientação política 'marxista-leninista', procurou organizar uma política educativa, aprovada em 1977 e implementada em 1978, como forma de responder às necessidades do país` e à consolidação da independência nacional. Esta política, como atestam os documentos e discursos políticos da época, é caracterizada, essencialmente, pelos princípios de igualdade de oportunidades, de gratuidade no acesso à escola e da continuidade de estudos.” (2006, p. 87) Com essa reforma, o sistema de ensino, que vigorou até 2000, ficou organizado da seguinte maneira: Educação pré-escolar; Ensino básico (de três níveis: $1^{\mathrm{a}}$ à $4^{\mathrm{a}}$ classe; $5^{\mathrm{a}}$ e $6^{\mathrm{a}}$ classes; e $7^{\mathrm{a}}$ e $8^{\mathrm{a}}$ classes); Ensino médio, que se dividia em técnico e normal; Ensino superior; e ensino e alfabetização de adultos.
} 
e objetivos do país. "Hoje diz-se que era demasiado politizado, mas a essa crítica pergunto sempre se podia ser de outra maneira."

O novo sistema tinha como pilares ser nacional, progressista e inclusivo, o que de fato provocou uma explosão escolar: durante o ano letivo de 1980/81, os alunos em todo o país somaram 1.800.000 (Balanço de Implementação da 2a Reforma Educativa em Angola, 2011, p. 7). Vale lembrar que em 1966, ainda no regime colonial, o número de matriculados em todo o território não chegava a 300 mil (PÉLISSIER \& WHELLER, 2013, p. 333).

Ermelinda Liberato afirma que o quadro de analfabetismo no país era dos mais precários em todo o mundo, o que fez com que o novo governo desse prioridade à educação, aplicando largos investimentos na área:

\begin{abstract}
A adoção de uma nova ideologia política, tendo em vista a formação do novo cidadão angolano, com uma nova personalidade, moldada nos ideais nacionalistas, conduziu à aprovação de reformas que erradicassem a iliteracia. A primeira alteração registrada, prende-se com a aprovação da lei n. 4, de 9 de dezembro de 1975, que nacionaliza o ensino e cria um Sistema de Ensino Geral, de formação técnica e profissional, assumindo o Estado a responsabilidade de oferecer educação a todos os angolanos. Em 1977 foi publicado o decreto n. 26/1977, que estruturou a política educativa como meio de consolidação da independência nacional e definiu a educação como um direito assente nos princípios da universalidade, livre acesso e igualdade de oportunidades no acesso à escola e à continuação dos estudos, bem como a sua gratuitidade no seu sentido mais amplo. (...) Em 1976 iniciaram-se as campanhas de alfabetização por todo o país, em escolas, empresas, fábricas, aldeias rurais, instituições militares, dando continuidade ao trabalho que já era realizado nos acampamentos militares, quando da luta pela independência (LIBERATO, 2014).
\end{abstract}

As novas legislações e os números evocados não deixam dúvida sobre as mudanças pelas quais passou o sistema escolar em Angola após a independência, o que também resvalou no ensino de literatura, que começou a contar com os autores nacionais em seu programa.

Carmo Neto relata que a UEA participou de definições junto ao governo de políticas voltadas para a literatura e/ou material didático nas escolas. "Como o secretário de Estado da Cultura era o poeta António Jacinto e o Ministro da Educação, Pepetela, e como havia escritores ligados a estes dois pelouros, criou-se uma comissão 
para elaborar os manuais de Língua Portuguesa, para o Ensino Geral e outros níveis do ensino".

Do ponto de vista da literatura, Pepetela afirma que foram introduzidos os autores angolanos nos manuais de ensino da língua portuguesa, que priorizavam extratos de livros, poemas ou contos pequenos desses escritores. Foi ainda elaborada uma antologia das obras desses autores, que servia de livro de estudo para classes mais avançadas. "Hoje há uma regressão e tenho dúvidas se no ensino de base ou médio se ensina os autores angolanos com obrigatoriedade. Depende muito do gosto dos professores", afirma. "A intenção sempre foi essa e sempre foi cumprida durante aqueles anos. A inclusão dos autores nacionais nos manuais”, concorda Luandino.

Tendo acesso ao livro de leituras do Ensino de Base datado de 1983 e com tiragem de 318 mil exemplares (Anexo E), vemos como se materializou essa prática. Depois da epígrafe de Agostinho Neto, que diz que "esta é a hora de juntos marcharmos corajosamente para o mundo de todos os homens", seguem-se, nesta ordem, até a $19^{\text {a }}$ das 121 páginas do material, textos de Ernesto Lara Filho, Luandino Vieira, Orlando Távora (pseudônimo de António Jacinto), Jofre Rocha e Agostinho Neto, todos membros fundadores da União. Neste início do manual também localizamos um texto de Amílcar Cabral, ícone da luta anticolonial em Guiné-Bissau e Cabo Verde, e um conto popular umbundo, além de um testemunho de um agricultor da Frente de Libertação de Moçambique (FRELIMO).

Avançando na análise da totalidade do livro de leituras, percebemos os alinhamentos políticos e estéticos estabelecidos por Angola, que incluiu no documento os autores brasileiros Jorge Amado, Manuel Bandeira, Cecília Meireles, Vinicius de Moraes e Antônio Callado. De Moçambique, além de contos populares, textos de Luís Bernardo Honwana, Mutimati Barnabé João e Samora Machel. Entre os estrangeiros, há ainda um texto do poeta russo Vladimir Mayakovski, do argentino Ernesto Che Guevara, da escritora de São Tomé e Príncipe Alda Espírito Santo, do africanista britânico Basil Davidson e de Carlos Estermann, antropólogo missionário europeu que estudou etnias do sul de Angola.

Os portugueses marcam sua presença com apenas dois nomes: Alves Redol, cuja obra possui uma perspectiva social e de crítica ao regime, e Miguel Torga, também oponente da ditadura salazarista. Os angolanos, no entanto, são predominantes no livro, sendo que os textos de alguns deles, como Agostinho Neto, Luandino, Jofre Rocha e António Jacinto, repetem-se mais de uma vez. Na relação de angolanos constam ainda 
os seguintes nomes: Carlos Rocha Dilolwa, Pepetela, Castro Soromenho, Boaventura Cardoso, João Abel, Lucio Lara, Uanhenga Xitu, Oscar Ribas, Aires de Almeida Santos e Arnaldo Santos.

Além dos autores, preenchem o material textos não assinados, fábula umbundo, provérbio cabinda, declarações de um vietnamita do sul sobre a guerra de resistência contra os Estados Unidos, provérbio humbe, conto popular quioco, provérbio cuanhama, declaração de um guerrilheiro do MPLA, fábula cuanhama, conto popular de São Tomé e Príncipe, resoluções do I Congresso do MPLA e declarações de um combatente das Fapla (Forças Armadas Populares de Libertação de Angola).

Sem nos aprofundarmos na biografia e obra de cada autor que está presente nesse material didático preparado pelo governo angolano, são todos nomes que, por sua atuação política ou literária, estão alinhados com os ideais da independência, da angolanidade ou ainda das práticas marxistas-leninistas do governo angolano. Os textos como contos e testemunhos caminham na mesma direção, valorizando a cultura local e de outras nações que passaram por processos de resistência. Na quarta capa o dizer "estudar é um dever revolucionário" (Anexo F) fecha o livro, evocando os ideais de educação do brasileiro Paulo Freire.

Este processo - a inclusão de autores angolanos nos manuais e sua valorização parece ter sido unanimidade. Pepetela afirma que entidades como a UEA e o Inald não apresentavam diferenças ideológicas profundas, de maneira que era fácil articular as diretrizes para a promoção da literatura angolana. "De facto todos estávamos de acordo em divulgar a literatura angolana que, a par da música, moldou a nação. Haveria livros escritos no estrangeiro, poucos, que foram ignorados. Como houve músicos que preferiram o exílio."

\subsection{3 - Números e coleções}

Se a fala carregada de orgulho de Luandino sobre as altas tiragens suscita alguma suspeição, ela logo se desfaz ao analisarmos os livros do período. Os materiais a que tivemos acesso mostram uma tiragem que varia de 5 mil exemplares, em média, até 20 mil para cada livro. Observemos os livros, cujos respectivos anexos mostram capa e ficha catalográfica, editados pela União: 


\begin{tabular}{|c|c|c|c|c|c|}
\hline Livro & Autor & Característica & Ano & Tiragem & Anexo \\
\hline $\begin{array}{l}\text { Manguxi da } \\
\text { nossa esperança }\end{array}$ & Antologia & Poesia & 1979 & $10 \mathrm{mil}$ & $\mathrm{G}$ \\
\hline $\begin{array}{l}\text { Estórias do } \\
\text { cágado }\end{array}$ & $\begin{array}{l}\text { Contos } \\
\text { tradicionais } \\
\text { angolanos }\end{array}$ & Prosa & 1979 & $10 \mathrm{mil}$ & $\mathrm{H}$ \\
\hline $\begin{array}{l}11 \text { poemas em } \\
\text { novembro }\end{array}$ & Manuel Rui & Poesia & 1984 & $5 \mathrm{mil}$ & I \\
\hline $\begin{array}{l}\text { No país da } \\
\text { brincaria }\end{array}$ & $\begin{array}{l}\text { Dário de } \\
\text { Melo }\end{array}$ & Infantil & 1988 & $20 \mathrm{mil}$ & $\mathrm{J}$ \\
\hline
\end{tabular}

A título comparativo, hoje em Angola a editora Chá de Caxinde ${ }^{26}$ possui tiragens médias de 1 mil exemplares, que, de acordo com seu presidente Jacques Arlindo dos Santos, raríssimas vezes chegam a uma $2^{\text {a }}$ edição. Dos cerca de 150 títulos em catálogo, cerca de 12 tiveram "honras de segunda edição".

Pepetela afirma que "as tiragens tornaram-se de facto astronômicas para a quantidade de pessoas que sabiam ler". Ele supõe que o livro Sagrada Esperança, de Agostinho Neto, deva ter ultrapassado, em todas as edições e reedições, os 500 mil exemplares. Sobre suas obras, o que mais vendeu informa ser As aventuras de Ngunga, que teve edições de 20 mil e, por duas vezes, 50 mil exemplares, tendo ultrapassado "em muito" os 200 mil exemplares.

O Mayombe também andou lá perto, embora fosse para adultos. O Ngunga era fundamentalmente para um público juvenil, embora os adultos o tenham lido também. Então, o principal editor era a União de Escritores Angolanos. Na melhor altura, a primeira edição era de 5 mil exemplares para poesia e 10 mil para romance. Isto para todos os escritores.

Um dos exemplos citados pelo pesquisador Russel Hamilton confirma esse momento superlativo do livro em Angola: em menos de um ano, 40 mil exemplares do livro Sagrada Esperança, do poeta e presidente Agostinho Neto, foram vendidos.

\footnotetext{
${ }^{26}$ A Chá de Caxinde foi fundada como centro cultural em 1989 e nos anos 2000 outra atividade veio se juntar a seu diversificado cardápio: a edição e comercialização de livros. Com 150 títulos editados, entre romances, livros de contos e poesias, ensaios e obras infanto-juvenis, a Chá de Caxinde publicou autores como Pepetela, Arnaldo Santos, Boaventura Cardoso e Ruy Duarte de Carvalho, nomes que, nos anos 70 e 80, viram suas obras alcançar as altas tiragens da UEA.
} 
A UEA era responsável pela maioria dos livros de literatura (romance, poesia, conto e drama) editados em Angola nesse período. "Penso que aproximadamente $80 \%$ dos livros literários foram publicados pela UEA. As outras editoras limitavam-se a publicar obras integradas em concursos de literatura, como o Inald", afirma Carmo Neto.

Embora hoje seja difícil precisar o volume total do que foi editado pela União ao longo dos anos - a própria instituição afirma não possuir esses dados -, Hamilton conseguiu, no calor daquele momento, levantar o que foram os três primeiros anos de atividade da UEA. De acordo com ele, de 1976 a 1978 a União editou 26 livros, seis livros de bolso e doze cadernos, somando pouco mais de 455 mil exemplares. Já em 1979, em apenas um ano, a produção se equipara à do triênio: 26 livros, cinco livros de bolso e doze cadernos, chegando a um total de 343 mil exemplares ${ }^{27}$.

Segundo Carmo Neto, não é possível calcular com exatidão os números em torno dos livros nos anos 70 e 80 . No entanto, ele afirma que os mais vendidos, com tiragens de 10 mil exemplares, teriam sido as obras de Pepetela, Manuel Rui, Agostinho Neto, Arlindo Barbeitos, António Jacinto, António Cardoso, Boaventura Cardoso e Jorgre Macedo, "para citar os que melhor se recordam". Já o escritor mais editado foi Luandino Vieira.

Além de romances, novelas, livros de contos e poesias e antologias, a UEA possuía coleções com periodicidade relativamente regular. A mais longeva e citada entre os entrevistados foi a Lavra \& Oficina, que, de 1977 a 1991, chegou a uma centena de títulos. Tendo começado como suplemento cultural do Jornal de Angola, transformou-se em gazeta própria da União ${ }^{28}$ e, posteriormente, em cadernos de poesias e contos com periodicidade quase mensal e tiragem média de 10 mil exemplares. $\mathrm{O}$

\footnotetext{
${ }^{27}$ Os números sobre as edições da UEA não são unânimes. A Gazeta Lavra \& Oficina fala em 450 mil exemplares nos anos que vão de 1976 a 1979, entre livros, cadernos e jornais (1980, p. 3). Matéria veiculada em 03 de janeiro de 1985 no jornal norte americano The New York Times, que tem como fonte os membros da União e escritores Luandino Vieira e Pepetela, afirma que em 1979 a impressão total teria sido de 500 mil exemplares. A mesma reportagem confirma que, já em 1983, a produção caiu para 150 mil cópias, devido à guerra civil que, entre outros entraves, induziu à escassez de papel.

${ }^{28}$ Embora os entrevistados tenham citado o jornal da União apenas na ocasião de comentarem sobre os cadernos, a Gazeta da UEA era o meio de comunicação oficial da instituição, refletindo portanto seus discursos e práticas, e, devido a sua periodicidade e conteúdo, podemos depreender que de grande relevância para a organização. Com cerca de 12 páginas, possuiu ao longo do período analisado uma estrutura quase regular, trazendo as seguintes seções: editorial; matéria sobre o tema de capa; espaço para poesias e contos de membros da UEA, mas também de novos nomes, chamado de "ponto de partida"; um "inquérito aos escritores", cujas perguntas se repetiam a cada edição; além das novidades sobre tudo o que era relacionado à literatura, como a inauguração de uma livraria, e temas ou mensagens ligados aos Pioneiros (Organização dos Pioneiros de Agostinho Neto). Os primeiro boletins eram comercializados ao preço de KZ 10,00. O Anexo M traz as capas das Gazetas a que tivemos acesso, do ano de 1979 até 1985, muitas delas em homenagem a Agostinho Neto.
} 
primeiro deles foi 11 Poemas em Novembro, de Manuel Rui, que durante sete anos reeditou, a cada novembro, mês da independência do país, novas versões de seus poemas.

O nome da coleção, como explicita Luandino, é referência ao nascimento do país, "que se queria baseado na aliança 'operário-camponesa". E também porque "são os textos de nossa lavra, bons ou maus, conforme a oficina do escritor..." Sua confecção era materialmente singela, de uma dimensão menor que um livro padrão que conhecemos hoje (Anexo L) e, justamente devido a essa condição, os cadernos eram, segundo Hamilton, os únicos impressos da União feitos em Luanda, porque os demais seguiam sendo elaborados em Lisboa.

Como nos conta Luandino quando lhe indago sobre a periodicidade do Lavra \& Oficina:

\begin{abstract}
Era quando podíamos, quando havia papel. Quando havia papel não, quando sobrava na tipografia papel das publicações oficiais, os donos da tipografia, que eram amigos da União dos Escritores, diziam 'sobraram as aparas'. E das aparas das publicações do Parlamento do Governo, porque eram os únicos que tinham autorização permanente para importar papel, nós fazíamos os cadernos Lavra \& Oficina. Se repararem hão de ver que eles têm aquele formato todos e que aquilo é o que sobra do papel num momento em que é guilhotinado para imprimir os livros e os relatórios, o que sobrava nós fazíamos. Portanto isso dava-nos a vantagem que tivemos de poder fazer esse movimento editorial de quase 100 cadernos Lavra. Depois, pronto, tornou-se uma tradição também. A medida que fomos publicando também o banco nos foi dispensando algum dinheiro estrangeiro para importar papel e aquilo depois institucionalizou-se. Mas foi assim que começou.
\end{abstract}

É possível vislumbrar, nessa passagem, como o escritor extrapola seu papel de autor para se ocupar, para além da criação, das demais etapas do processo produtivo do livro. A guerra e os parcos recursos oferecem condições materiais que sem dúvida impactam o fazer literário. A coleção Lavra \& Oficina é exemplo disso: seu formato reduzido, medindo $18 \mathrm{~cm} \mathrm{x} 14 \mathrm{~cm}$, certamente acolhe melhor obras poéticas do que aquelas do gênero romanesco.

Para além da Lavra \& Oficina, a UEA possuía uma coleção que consistia em reedições de obras, mas em formato de bolso e mais baratas, denominada $2 \mathrm{~K}$. Os livros em edições tradicionais, a exemplo de Luuanda, de Luandino Vieira, Dizanga Dia Muenhu, de Boaventura Cardoso, e Muana Puó, de Pepetela, saíam pela Série Contemporâneos. 
A UEA foi ainda grande estimuladora da literatura infantil, editando a Coleção Acácia Rubra, com média de 5 mil exemplares, e que, ao longo do tempo, foi adquirindo maior cuidado gráfico, chegando a serem impressos livros em capa dura. Os primeiro cinco livros com o selo Acácia Rubra, lançados em 1988, foram: Um poema e sete estórias de Luanda e do Bengo, de José Alves; Era uma vez... Que eu não conto outra vez, de Octaviano Correia; Velhas estórias, roupa nova, de Gabriela Antunes; Fá... Pe... Láááa!!!, de Maria de Jesus Haller; e No país da brincaria, de Darío de Melo.

Nas publicações dessa coleção, nota-se a inclusão, em suas páginas iniciais, de uma foto do presidente Agostinho Neto ao lado de uma criança e, abaixo, a frase "Nós queremos que os homens sejam cada vez mais felizes" (Anexo N). Este uso da figura do presidente, sobretudo em livros destinados ao público infantil, faz das obras um veículo para mensagens que ultrapassam o literário e que servem ao propósito de fortalecer a imagem do líder que, ao longo de sua trajetória, carregou as alcunhas de Kilamba Kiaxi (condutor dos homens, em kimbundu) e guia imortal da pátria e da revolução (PINTO, 2015, páginas 729 e 738).

Uma outra vertente da literatura angolana apoiada pela UEA foi a banda desenhada (BD), que no Brasil chamamos de história em quadrinhos, em muito tributária da atuação de Henrique Abranches, membro fundador da União. Ele foi o responsável por, ainda no período de luta anticolonial, criar a obra Pela liberdade, contra a escravidão, que possuía caráter nacionalista e, em 1965, tinha destino certo: os guerrilheiros do MPLA nas matas do país. Entre as publicações de BD da União estão as aventuras de um personagem chamado Masala, em títulos como Masala, O Leopardo - Um passo para a liberdade, e $O$ canto de Luzunzi. Masala, o Leopardo. A série foi dirigida por Henrique Abranches, com argumento e desenhos de Lito Silva, e lançada em 1989 (Anexo O).

\subsection{4 - Recursos}

A sobrevivência da UEA, pelo que foi possível apurar, decorria do apoio financeiro do governo, mas também, em menor parte, da venda de livros. De acordo com Luandino, o Ministério das Finanças atribuía uma pequena verba da república para a União, chamada de duodécimo. Carmo Neto lembra que a "UEA sempre contou com subsídios do governo e de mecenas, como a Sonangol”. 
Embora o artigo 38 de seu estatuto, que versa sobre os fundos da UEA, elenque em primeiro lugar, como fonte de receita da União, "quota e demais prestações dos membros", essa informação não foi confirmada pelos interlocutores.

Sobre os direitos de autor, a União pagava regularmente os escritores, que recebiam $20 \%$ do preço de capa, valor superior à média atual do mercado brasileiro, por exemplo, que gira em torno de 10\%. Como fala Luandino: "O pagamento dos direitos do autor dava ou deu por vezes para pagar a prestação de viatura que queriam comprar; para ver a quantidade de exemplares que se chegaram a editar". O autor faz questão de distinguir a atuação dos escritores que também ocupavam cargo político: "Antonio Jacinto, poeta, membro do bureau político do MPLA, só usava o carro do MPLA nas funções oficias. Assim que ele passava a cidadão, poeta, usava um carro velho que tinha e ia buscar o dinheiro à União dos Escritores".

\title{
3.1.5 - Circulação de livros e leitores
}

Se Pepetela diz que as tiragens eram astronômicas para o tanto de gente que sabia ler, a pergunta se impõe: para quem eram destinados os milhares de livros da UEA e suas volumosas edições?

Luandino oferece uma resposta sobre o que seria um público cativo para esse livros:

\begin{abstract}
Houve um momento em que chegamos a ter um acordo, um acordo verbal, com os setores da logística do Estado Maior Geral das Fapla, portanto o Exército Nacional. Então entregávamos o que fazíamos. Fazíamos uma tiragem de 5 mil, por exemplo, entregávamos logo 2 mil ou 3 mil às FAPLA, as Forças Armadas. Por que? Porque havia no interior das próprias Forças Armadas o movimento de alfabetização, de educação, de cultura, de aumento do nível cultural dos combatentes. E por isso os cadernos e as publicações da Lavra \& Oficina chegaram a ser distribuídas quando eram distribuídas as rações de combate ou as munições. Quer dizer, o combatente, ao mesmo tempo que recebia a ração e as munições, recebia um livro.
\end{abstract}

Um caso relatado por Luandino ilustra a história, de maneira saborosa. Ele conta que certa vez desceu de um avião em Angola e, entrando no aeroporto, chegou a ver o "camarada" que guardava a porta naquele tempo de guerra civil com a espingarda encostada no muro e ele a ler $O$ mestre Tamoda, do Uanhenga Xitu. "Lê, faz bem ler os 
livros, mas põe a Kalashnikov no ombro, pô”, disse Luandino a ele. Para mim, já o diz entre risos.

Para Pepetela, além do fato de alguns escritores terem sido guerrilheiros e isso ter ajudado no status que a literatura alcançou no país, havia sobretudo uma "curiosidade enorme das pessoas em ler o que sabiam ter estado escondido há tanto tempo. Muitos queriam de fato conhecer o que realmente tinha sido censurado. Era uma questão de patriotismo, de se descobrir a nova nação". Isso explicaria, para ele, a vontade de ler e a aquisição das publicações.

As histórias resgatadas revelam, com efeito, um apreço pelo livro. Luandino relata o encontro com uma senhora com trajes tradicionais, analfabeta, que estava comprando livros para seu neto na sede da União. O detalhe é que o neto ainda não havia nascido. "Minha filha casou, estou a comprar livros para meu neto", disse a mulher a Luandino.

Outro fator que, segundo Luandino, ajudava as vendas das publicações da União era a falta de importação de livros no período. "Então tudo quanto fazíamos era vendido e consumido".

Sobre a distribuição dos livros, Luandino explica que havia um ponto de venda na União, além de duas ou três livrarias em Luanda. Os livros eram distribuídos também nas províncias, às Forças Armadas e a algumas instituições, como bibliotecas escolares.

Aqueles que iam para o mercado iam como mercadoria que servia de moeda quase. Um livro era comprado a um euro, um quanza, valor simbólico, e no valor de troca eram de 10. Nós assistíamos a pessoas que iam à União comprar 5, 10 livros do Pepetela. Estou-me a lembrar da Geração da Utopia, assim que saiu foi logo vendido nos semáforos de trânsito por crianças que compravam, sei lá, a 10 por vender a 100.

Além da fácil circulação e do preço acessível, porque subsidiado, havia uma rede de ação para promover a leitura. Carmo Neto afirma que "havia uma publicidade eficiente em torno da obra publicada. Os escritores eram bem conhecidos. E havia debates nas escolas do ensino médio e nas universidades à volta das obras. Essencialmente havia uma rede de distribuição livreira que levava o livro a todo o país". Pepetela relata que, entre as atividades que visavam um público leitor, havia as idas de escritores a escolas para falar com estudantes e a programas de rádio e de televisão (só havia um canal de TV, estatal). Também foi criado O Jardim do Livro Infantil, 
momento em que escritores liam passagens de seus livros infantis para crianças, num jardim. No que tange à crítica literária, o Jornal de Angola tinha um suplemento cultural, no qual eram editados poemas e contos e havia notícias ou críticas literárias. "Era o que se fazia com os poucos meios de que dispúnhamos".

Muitas das ações voltadas ao público infantil eram partilhadas entre UEA e Inald, tanto que aparecem nos discursos de ambas instituições. Vejamos este trecho do editorial do número 15 da Gazeta Lavra \& Oficina da União, de 1979, cuja capa é dedicada ao Jardim do Livro Infantil.

\begin{abstract}
Neste ano Internacional da Criança que agora finda o nosso país contribuiu, na medida do possível para que à infância fosse dada uma atenção especial, atenção que mais não é do que o início de uma constante de realizações que devem tornar-se o dia a dia do nosso país, para que as nossas crianças venham a ter a infância feliz que à maioria de nós faltou. E uma dessas constantes, e aquela que mais diretamente se prende com a nossa atividade, é a literatura. E nesse campo, não obstante todas as dificuldades que ainda se nos deparam, fez-se o possível para suprir as faltas. O lançamento de várias obras literárias dedicadas à criança, de livros de histórias tradicionais, adaptadas ou de escritores angolanos, a abertura do Jardim do Livro Infantil, numa iniciativa do Inald, levam-nos a sentir que as responsabilidades neste campo cresceram. (...) E, lembramos aqui as palavras do saudoso Camarada Presidente Agostinho Neto no dia 1 de junho de 1979 (...): 'Sim, nós fizemos aquilo que a nossa geração queria que se fizesse para proteger as crianças que virão depois, que devem ser ainda muito mais felizes do que aquelas que existem hoje no nosso país. País, que ainda não tem tudo aquilo que é necessário para a sua vida'. Contribuamos também nós, escritores, com a nossa quota parte para essa felicidade, dedicando às crianças as nossas mais belas obras. (Lavra \& Oficina - Gazeta da UEA; $n^{\circ} 15$; dezembro de 1979, p. 2)
\end{abstract}

Desta longa citação, extraímos duas informações relevantes. A primeira delas diz respeito à atribuição da criação do Jardim do Livro Infantil ao Inald, ainda que as duas instituições tenham citado a ação em seus discursos, o que nos faz depreender que ambas participaram do Jardim, mas, principalmente, que as duas organizações estavam afinadas em suas práticas. Outro dado de extrema importância é a preocupação com a formação de um público leitor infantil e o entendimento da União do significado da literatura para as crianças: o universo literário estaria, aqui, vinculado não necessariamente a uma obrigação, instrução ou formação cultural, mas à felicidade. 
Uma literatura infanto-juvenil, apontam Tania Macêdo e Rita Chaves, era anseio das entidades ligadas ao governo, de maneira que diversas ações foram dedicadas às crianças:

\begin{abstract}
Após a independência do país, houve uma preocupação dos órgãos de cultura do governo em incentivar a chamada literatura infanto-juvenil, buscando formar hábitos de leitura entre o público mais jovem. As iniciativas foram variadas e, dentre elas, podemos citar a Coleção Pio-Piô, lançada em 1982 pelo Inald, a publicação da página 1 de Dezembro, do Jornal de Angola, ou ainda a coleção Acácia Rubra, da UEA, voltada especialmente para os livros infantis e juvenis, assim como a criação de Jardins de Leitura em várias províncias e a realização de programas na Rádio Nacional, dentre os quais destacamos o Rádio Piô, dirigido inicialmente pelo escritor Otaviano Correia (MACÊDO \& CHAVES, 2007, p. 155).
\end{abstract}

Vemos, portanto, que não apenas os livros estavam a serviço dos próprios livros, mas uma rede de comunicação, em muito fincada no rádio e no jornal impresso, foi pensada para garantir a expansão dos temas literários entre os mais jovens.

Nesta mesma Gazeta, a União promove os livros infantis publicados pelo Inald, destacando que a literatura para crianças era uma lacuna urgente a preencher. "Coube ao Inald essa tarefa, ou, pelo menos, iniciar o trabalho ingente de dar às nossas crianças os livros mais de acordo com o meio onde essas crianças nasceram e cresceram, fugindo a um tipo de literatura que a sociedade de consumo, na era colonial, distribuía com o intuito de alienar e fazer prevalecer a ideologia da classe dominante" (Gazeta Lavra \& Oficina, $\mathrm{n}^{\circ} 15$, dezembro de 1979 , p. 10).

Ao falar de literatura infanto-juvenil, não podemos deixar de abordar $A s$ aventuras de Ngunga, primeiro livro de Pepetela, escrito em 1973, quando, na região da Frente Leste do MPLA, foi diretor do Centro Augusto Ngangula. O livro, publicado pela UEA em 1976, narra a história de um órfão de 13 anos, cujos pais morreram na guerra anticolonial, que se faz guerrilheiro e se transformou em símbolo da luta pela independência, por meio de uma história de desafios e superação. Um dos aspectos relevantes da obra é que foi criado com fins didáticos. Impresso em mimeógrafo, o livro serviu como material de leitura nos projetos educacionais do movimento ainda no período colonial. 


\subsection{6 - Makas e outras atividades}

Com os diversos interlocutores que conversamos sobre os tempos idos e atuais da União, um tema é recorrente: as "makas das quartas-feiras". Criada pelo então secretário-geral Luandino Vieira, o encontro acontecia todas as quartas-feiras na sede da União e buscava o debate de ideias não apenas em torno da literatura. Como afirma Carmo Neto, eram pautas variadas e "não políticas". Abertas ao público, englobavam, segundo Luandino, todos os temas: "não havia tabus, desde ballet à economia". O modelo que as makas seguiam era o de exposição de um tema por um apresentador e uma subsequente discussão entre todos os presentes na plateia. A primeira maka realizada foi conduzida por Eugênio Ferreira sob o tema "Há uma literatura angolana?". Também eram realizadas makas com pesquisadores de literatura angolana de outros países que visitavam a UEA, de maneira que um internacionalismo estava presente nesses encontros.

Luandino relata ainda a passagem de dois jornalistas do The New York Times por Luanda, episódio que reafirmaria o tom democrático das makas. Segundo ele, os jornalistas foram a Angola por uma semana para realizar uma série de reportagens sobre diversos aspectos da vida no país, em uma altura em que se avizinhava uma melhoria da relação com os Estados Unidos, que durante a guerra civil forneceram apoio à Unita, "quando perceberam que os melhores aliados eram o MPLA". No regresso dos jornalistas, uma complicação no aeroporto impediu que retornassem a seu país na data acertada e eles ficaram com mais tempo livre naquela noite. Era quarta-feira. Alguém indicou o evento na União dos Escritores, a que um dos jornalistas teria comparecido. De acordo com Luandino, ele saiu dali, fez sua série de artigos sobre Angola e a única crônica positiva que teria saído foi sobre a maka. Em meio às tantas dificuldades que encontrou no país, como o racionamento e a falta de liberdade, as makas seriam um interessante espaço de freewhelling debate, ou debate de roda livre, conforme conta Luandino. ${ }^{29}$

De acordo com Carmo Neto, além das makas, outros eventos eram realizados na União para a promoção da leitura ou a aproximação com o público leitor, entre eles

\footnotetext{
${ }^{29}$ Pela imprecisão da data e dos termos no relato de Luandino, ficou a dúvida se a matéria localizada no arquivo do jornal americano The New York Times, datada de 03 de janeiro de 1985, sobre a União dos Escritores é a mesma a que se refere Luandino (Anexo P). A reportagem cita brevemente as makas, usando o termo freewhelling debate, e discorre sobre a literatura angolana, que teria se distanciado do realismo socialista da União Soviética, e não sobre outro aspecto da vida angolana, como se recorda Luandino.
} 
lançamentos de livros e apresentações de "grupos culturais de relevo na sociedade angolana", além de eventos não necessariamente ligados à literatura. Ele relata, por exemplo, a conferência de imprensa realizada para apresentar um mercenário sulafricano capturado em Cabinda e que teve lugar na União.

Observando o jornal da União, vemos que essas atividades eram frequentes. Sob o título "Atividades culturais da UEA em 1981”, por exemplo, lemos acerca do registro de ida de escritores vinculados à União a empresas, sindicatos e escolas, tanto em Luanda quanto em outras províncias:

No mês de abril, os escritores Eugénio Ferreira, Rosario Marcelino e Octaviano Correia foram a Fábrica ONLY em Viana falar sobre "A juventude e a cultura na reconstrução nacional". Algumas semanas depois, os operários da Fábrica de Calçado Universo participaram numa palestra sobre o tema " $\mathrm{O}$ operário, a cultura e a revolução", com os escritores Henrique Abranches, Raúl David e Rosário Marcelino. Entre várias outras palestras assinalamos a de Raul David sobre cultura e aculturação no Sindicato Nacional de Educação, Cultura e Comunicação Social, e a de António Cardoso sobre a literatura angolana no Liceu Mutu Ia Kevela para os professores de português na província de Luanda. Alguns membros da União dos Escritores Angolanos deslocaram-se durante o ano às províncias. António Jacinto, Domingos Van-Dúnem e Carlos Pimentel participaram, na Província de Bengo em diversos atos culturais (...) (Lavra \& Oficina $-n^{\circ} 40-45$, Jan/Jun - 1982, p. 29)

É perceptível o esforço em levar para fora dos círculos literários as questões não somente ligadas à literatura, mas à vida intelectual de Angola.

Outro tema citado com insistência pelos entrevistados foram as Brigadas Jovens de Literatura. Apesar de não ser uma promoção da União, a instituição apoiou a iniciativa, criada em 1980 para incentivar a criatividade literária da juventude. Para Luandino, esse encontro de jovens para produzir literatura seria resultado do prestígio alcançado pela literatura devido ao fato "dos grandes poetas todos" terem participado do movimento pela independência, a exemplo de Uanhenga Xitu, Manuel Pacavira e António Jacinto. "Esse fascínio ainda hoje se mantém pela literatura, pela poesia. Todo mundo acha que pode fazer poesia, que é poeta, e é."

As brigadas começaram em Luanda, mas se espalharam por todo o país e inclusive em Moscou e Cuba. De acordo com Luandino, não eram dois ou três, mas a 
"juventude do país" agrupou-se nas brigadas para produzir seus cadernos, sobretudo de poesia.

A União deu apoio desde o início, deu apoio no meio de uma confrontação de gerações, de poéticas. Porque nós éramos os herdeiros da poesia do coletivo, éramos nós. A geração de 80 começou a recolocar outras questões, mais subjetivas, pessoais. $\mathrm{O}$ mais interessante de tudo, e isso é natural, eles foram desligando, à medida que as instituições avançavam, deixou de haver ações muito coletivas, passou a haver ações mais institucionais. O que é interessante é que a produção dessa altura tem incerteza, é a geração das incertezas. O que nós trazíamos já não lhes diziam $100 \%$, mas eles também não tinham certeza do que viria, como viria e para quê viria. A produção dessa época, das brigadas dessa época, tem esse traço comum, há qualquer coisa de incerto no meio de tudo aquilo.

A afirmação coincide com a de Carmen Lucia Tindó Secco, que vê no movimento das Brigadas o reflexo da euforia que contaminava o país recém liberto:

O Movimento das Brigadas foi contagiante e espontâneo, tendose espalhado não apenas por diversas províncias angolanas (Luanda, Lubango, Huambo, Cabinda, Uíge e outras), mas também entre angolanos que se encontravam no exterior: em Cuba e na Rússia, por exemplo. Das Brigadas, três foram as mais representativas: a de Luanda; a do Lubango - da Huíla (fundada em 1982) -, cujas produções literárias e ensaísticas circularam no folheto "Hexágono"; e a do Huambo (criada em 1984), denominada "Brigada Jovem de Literatura Alda Lara", cujos poemas e ensaios foram divulgados no folheto "Gênese". Funcionando como autênticas oficinas literárias, as Brigadas congregaram jovens poetas, mantendo viva e acesa a importância do constante e renovador processo do fazer poético. Tais centros literários serviram não só à discussão crítica e ao repensar dos ideais ideológicos legados por Agostinho Neto e pelas lutas em prol da Independência, mas também ao exercício da liberdade de cada cidadão e ao desenvolvimento da pesquisa estética rumo à renovação da poesia angolana (SECCO, 2006, p. 84).

Essas Brigadas constituíram terreno fértil para uma outra poética, já distante "do tom épico dos poemas de combate que dominaram a cena literária entre 1960 e 1975, abraçando um viés lírico e uma reflexão profunda acerca de questões humanas e literárias" (SECCO, 2006, p. 84), afirma Carmen. Em concordância com Luandino, ela explica que depois de 1985, devido ao acirramento da guerra entre UNITA e o MPLA, e 
sobretudo nos anos 90, depois da queda do Muro de Berlim, "um tom melancólico passou a envolver a produção poética das Brigadas Jovens, havendo um clima de desencanto em razão do não cumprimento de muitos dos ideais preconizados pela independência". O que aconteceu foi que as convicções antes tão claras deram lugar a incertezas. Assim,

no campo da linguagem, a poética pós-1985, de um modo geral, propôs a radicalização do projeto de recuperação da língua literária, aproveitada em suas virtualidades intrínsecas e universais, sem os regionalismos característicos da literatura dos anos 1950. Erigiu a metaconsciência e o traço crítico como estratégias estéticas prioritárias, afastando-se completamente do panfletarismo ideológico frequente nos anos 1960. Elegeu a ironia e a paródia como artifícios literários de denúncia da corrupção e das contradições do poder. (...) Profunda melancolia recobre, desse modo, grande parte da poética angolana produzida entre 1985-2002 (que abarca tanto o Movimento das Brigadas Jovens e o do Brigadismo Literário, como a poesia produzida fora desses Movimentos). Luis Kandjimbo designou como "geração das incertezas" a poesia dos anos 80 e também a dos anos 90 , cujos traços constantes são as temáticas da decepção e da angústia diante da situação de Angola frente à fome e à miséria social exacerbadas pela guerra civil entre a UNITA e o MPLA (SECCO, 2006, p. 86).

As memórias em torno das Brigadas são plurais. Um dos leitores entrevistados para o quarto capítulo desta dissertação, Carlos Sérgio Ferreira, oferece a seguinte visão:

Éramos três ou quatro jovens que já tínhamos abandonado a Juventude do MPLA e estávamos muito descontentes. Apoiados pela União dos Escritores (Luandino, Manuel Rui, Pepetela, António Jacinto, meu pai - Eugénio Ferreira) criamos a primeira associação democrática de Angola no pósindependência. Só nos aguentamos dado o fato de sermos filhos de quem éramos. O Buca Boavida por ser filho do então ministro da Justiça, Diógenes Boavida. Eu, por ser filho do Presidente do Tribunal da Relação e jurista muito respeitado, a Irene Neto por ser filha do Agostinho Neto. Mas tivemos sempre a segurança de estado a controlar-nos. Até que extinguimos a brigada de Luanda, quando a JMPLA nos tomou de assalto e criou uma brigada jovem de literatura de Angola, para destruir a nossa autonomia e as nossas posições pouco simpáticas para com o poder político. 
Alguns aspectos chamam a atenção na fala de Carlos Sérgio. O primeiro deles é sua percepção de que a Brigada seria a primeira associação democrática do pósindependência, o que exclui a União, primeira instituição da nova nação, do rol das organizações que atuam livremente, sem a ingerência do Estado. Ele explicita ainda um descontentamento com as questões políticas como base para criação do movimento das brigadas, de maneira que a literatura seria um dos caminhos possíveis para combater essa insatisfação. Assim, se na fala de Luandino percebemos uma diferença de poéticas entre a geração da União e a das brigadas, Carlos Sérgio evoca uma ruptura no campo político. Fica evidente também nesta fala um caráter censor do Estado angolano, que só teria permitido essa "associação de descontentes" por conta de suas relações familiares de prestígio, formadas por pessoas do próprio governo. Por último, uma revelação que não aparece nas fala dos outros interlocutores: a brigada teria sido criada por esses jovens e posteriormente a Juventude do MPLA dela se apropriou, abafando, em alguma medida, o seu caráter transgressor.

De qualquer maneira, o movimento das brigadas caminhada de maneira estreita com a União, que publicou antologias de produção dos jovens das brigadas, como é o caso dos cadernos 33 e 34 da Coleção Lavra \& Oficina, que saíram com os títulos de Aspiração e $O$ caminho das estrelas.

\subsection{7 - Língua portuguesa, línguas nacionais e linguagem}

Ao buscar uma literatura propriamente angolana, que rompesse com aquela de cariz metropolitano, o desenvolvimento de uma linguagem particular foi uma importante via encontrada pelos movimentos e autores que, nos anos 50 aos 70, além de incorporar temas, personagens e focos narrativos revestidos de angolanidade, também procederam a uma transformação formal do texto. Entre as inovações estavam a incorporação do quimbundo e uma sintaxe própria, de modo a reinventar o português. Foi justamente essa a questão, lá atrás, que motivou esta pesquisa de mestrado, traduzida na seguinte inquietude: essa nova linguagem conseguiu de fato falar ao homem angolano, proporcionou uma maior identidade ou facilitou a apropriação dos textos pelo leitor local? Quando estivemos com o autor símbolo dessa ruptura formal, a pergunta foi inevitável: a linguagem usada facilitou a interlocução com o angolano? Eis a resposta de Luandino: 
O homem angolano não sabia ler. $98 \%$ não sabia ler. Para os que sabiam ler e escrever, não facilitou. Ou facilitou, não uma leitura, mas um reconhecimento do texto. $\mathrm{O}$ avanço nesse sentido era um avanço que correspondia também à radicalidade das nossas propostas, que era a independência política. Uma vez obtida a independência política essa radicalidade deixou de ter sentido dessa forma radical, permanece como motivo de criação, obviamente. Mas já não tem nem a importância nem a permanência que teve. Isso reconhecemos. Até porque o fator guerra civil obrigou à "universalização" da língua portuguesa naquele território. A guerra foi um fator também porque o Exército não está a escolher os falantes que se entendem uns com os outros para poder combater. Em perigo, em situação de guerra, a comunicação deve ser instantânea, ninguém podia andar com o tradutor ao lado. No meu ponto de vista, a guerra não tem nada de positivo. Mas de menos mau foi esse empurrão que deu (o estabelecimento da língua portuguesa).

Suas observações evocam outra questão crucial nas discussões das literaturas marcadas pelo colonialismo: depois de um intenso embate, de armas e de palavras, contra os regimes opressores, por que escolher a língua do inimigo para desenvolver a sua literatura?

Luandino explica que a discussão sobre o uso das línguas nacionais existiu “desde sempre, desde a fundação até hoje" na União, constituindo um "ponto de fricção, fricção positiva" entre os autores. Em seu entendimento, há diferentes correntes nos grupos de escritores sobre a apropriação dessas línguas, mas é inegável a dificuldade enfrentada por muitos criadores que "ousaram enfrentar" essa questão, porque usar a língua no ensino escolar e fazer produção literária são coisas bem distintas.

Um grande amigo meu, escritor, morreu há pouco tempo, o Uanhenga Xitu. Discutíamos quase diariamente isso estivemos oito anos presos juntos. Ele chegou a fazer uma experiência. Ele fez, parou no primeiro capítulo, disse "não posso". E era uma história simples: o homem saiu para cortar lenha para fazer fogueira enquanto a mulher ficou em casa. Escreveu então a história em português: e ele fez Manana. E ele que era um orador fantástico, ele tinha um conhecimento da língua quimbundo. Como ele dizia "eu sou totalmente analfabeto, mas eu sei falar". Mas a questão literária é diferente. Manuel Bernardo de Souza chegou a fazer três, quatro poemas na cadeia. Depois discutíamos e disse "não, também não é isso". (...) João Viário copiou, mas disse, "não, o que estou a escrever são histórias que me contaram quando era miúdo em quimbundo. Não é criação". 
De acordo com Luandino, o Instituto das Línguas Nacionais foi muito atuante e, diante das dificuldades enfrentadas na guerra, conseguiu realizar um trabalho "fantástico". Fator determinante para essas línguas não deixarem de ser faladas foi, segundo Luandino, a Rádio Nacional de Angola, que até hoje usa as línguas nacionais em sua programação. Segundo ele, essa diretiva de utilização das línguas é de 1975, que depois foi ampliada para o uso televisivo.

Apesar do panorama apresentado por Luandino, é sabido que durante todo o período a que se dedica essa dissertação não houve escolarização em línguas nacionais, o que só viria a ocorrer, de maneira parcial e em caráter de experimentação, em 2006, com a inclusão de seis das cerca de 20 línguas nacionais, no ensino. A primeira gramática do quimbundo, língua falada na região que inclui a capital Luanda, só será publicada em 2014.

De acordo com Luandino, essa discussão, que seria política e estética, não teria apoio do capital financeiro e humano que chega a Angola para reerguer um país totalmente exaurido pela guerra. "Isso não se compadece com as línguas nacionais. Não é prioridade para o capital e para os aliados do capital. E a classe burguesa angolana não está interessada nisso, por isso não investe nem financeiramente nem simbolicamente". Mas do ponto de vista literário, isso se revelaria na opção pessoal de cada escritor.

\section{2 - Instituto Nacional do Livro e do Disco}

\subsection{1 - Papel, funcionamento e principais obras}

Se reunirmos as publicações elaboradas pela União e aquelas que saíram pelo Inald, teremos um panorama se não completo, muito abrangente da totalidade de material que foi editado em Angola no período que vai de 1975 a 1991. Sabemos que há outras instituições que importavam ou faziam circular livros no país, a exemplo do Centro do Livro Brasileiro. Porém, de acordo com Pepetela, UEA e Inald eram as duas únicas editoras em Angola nesses anos.

Boaventura Cardoso, que dirigiu o Instituto desde sua criação, em 1977, até março de 1981, quando foi nomeado secretário de estado de Cultura, recorda que cerca de $30 \%$ do material que circulava no país passava pelo Inald. De acordo com ele, 
o objetivo do órgão era promover a literatura, assim como "incutir na sociedade angolana hábitos de leitura". Para Antonio Fonseca, que esteve à frente do órgão de 1983 a 1994, "acreditou-se sempre na importância do livro e da leitura para o desenvolvimento da nossa sociedade". Assim, o trabalho do Inald foi sobretudo de "integração e harmonização de todas as iniciativas e da ação de diferentes instituições nesses domínios".

O Inald voltou-se para a publicação de material de cariz literário e cultural. No entanto, sendo um órgão oficial do governo, operou também adquirindo e distribuindo obras técnicas, de rara elaboração no país.

Os requisitos para a publicação de um livro pelo Inald, de acordo com seus dirigentes, passavam pela qualidade estética e literária. As prioridades eram para o domínio das ciências sociais, literatura infantil, autores angolanos e obras de referência de autores africanos e da América Latina. Segundo Antonio Fonseca, "claro que os valores da angolanidade, da unidade nacional, e todos os que concorressem para a edificação do país eram importantes”.

Boaventura explica que

Numa primeira fase, a maior parte dos escritores angolanos era editada pela União dos Escritores Angolanos. Ao Inald cabia editar livros do domínio das ciências sociais e da literatura infantil e infanto-juvenil. Mais tarde o Inald fez muito sucesso com coleções dedicadas às literaturas da América Latina e de África. Quanto aos livros técnicos, não havia praticamente edições em Angola. Para corresponder à grande demanda, sobretudo proveniente da comunidade de estudantes e de investigadores, recorria-se à importação de tais livros de Portugal e do Brasil.

Boaventura nos fala em livros que tinham origem no Brasil, mas o fluxo de material em grande parte incluía revistas culturais que no país de origem circulavam em bancas de jornal, a exemplo da Coleção Gênios da Pintura, da Editora Abril.

Embora Boaventura cite a qualidade estética e literária como prioridade para a publicação de uma obra pelo Instituto, ele não deixa de fazer a ressalva sobre o cenário político e sua influência. "No entanto, e porque vigorava então um regime monopartidário, estava fora de hipótese a publicação, pelo Inald, de obras que veiculassem abertamente ideias contrárias ao referido regime." 
As tiragens dos livros com chancela do Instituto parecem reafirmar a euforia vivenciada pela União dos Escritores Angolanos. De acordo com Boaventura, por dois motivos principais: "porque havia uma grande avidez de leitura no seio do povo. Para além disso, os preços de venda dos livros eram módicos." Como ressalta António Fonseca, havia uma "vocação de massificação da leitura" no Instituto: "As tiragens variaram muito, entre os três e os dez mil exemplares, mesmo em poesia. Houve casos de edição de vinte mil exemplares e sucessivas reedições".

Como órgão do governo, o Inald dispunha de um fundo para importação de publicações, além de verbas oficiais para seu funcionamento. Os escritores recebiam seu direito de autor, o que parece ter sido sempre respeitado na Angola independente. Boaventura lembra que o país "subscreveu muito cedo as principais convenções sobre a matéria, enquanto membro da Organização Mundial da Propriedade Intelectual”, enquanto António Fonseca afirma que "o direito de autor sempre foi reconhecido em Angola e diga-se, as percentagens eram superiores ao que se paga normalmente no mercado editorial. Variavam entre os 15 e os 20 por cento sobre o preço de capa".

No início de sua operação, o governo financiou a totalidade das edições. Já em 1979 teve início o autofinanciamento, por meio da Empresa Estatal de Distribuição de Publicações (ENDIPU). Como relata Fonseca, ela foi criada para "assegurar a distribuição das edições do Inald, comercializar obras da União dos Escritores e suprir o mercado com publicações técnicas".

Os números revelados pelo Inald apontam uma coincidência com aqueles da União no que diz respeito a obras e autores mais publicados. Boaventura recorda que no período em que esteve à frente do Inald os escritores e livros mais vendidos foram ${ }^{30}$ : Sagrada Esperança (UEA, 1977), de Agostinho Neto; Luuanda (UEA, 1978), A Cidade e a Infância (1977, UEA), A Vida Verdadeira de Domingos Xavier (UEA, 1977), de José Luandino Vieira; Baixa e Musseques (UEA, 1980), de António Cardoso; As aventuras de Ngunga (UEA, 1979) e Mayombe (UEA, 1979), de Pepetela; Quem me dera ser onda (Inald, 1982), de Manuel Rui; e Gente de meu bairro (UEA, 1977), de Jorge Macedo.

Já Fonseca, que dirigiu a instituição na segunda metade dos anos 80, traz também a presença de outros autores africanos para além dos angolanos, lembrando que

\footnotetext{
${ }^{30}$ Interessa notar que Boaventura inclui na relação tanto livros publicados pelo Inald quanto pela União. Sua memória não faz essa distinção, oferecendo a visão de que as duas instituições estavam alinhadas. Fato é que muitos autores figuram nos catálogos das duas editoras. Na sequência dos títulos estão as instituições pelas quais foram realmente editados e seu ano de publicação.
} 
os "livros que marcaram época, a par da coleção infantil Piô-Piô"31", foram: Quem me dera ser Onda (Inald, 1982), de Manuel Rui; A Renúncia Impossível (Inald 1982), de Agostinho Neto, constituindo a primeira edição póstuma; e Sobreviver em Tarrafal de Santiago (Inald, 1985), sendo a primeira edição do livro de António Jacinto, que foi laureada com o Prêmio Noma, outorgado na Feira de Frankfurt.

$\mathrm{Na}$ literatura de autores africanos, ele cita os seguintes nomes, com destaque para os autores nigerianos: O bebedor de vinho de palma, do nigeriano Amos Tutuola; Os intérpretes, do nigeriano Wole Soyinka; A Flecha de Deus, Quando o mundo se despedaça e Um homem popular, do nigeriano Chinua Achebe; Sundjata, do guineense Djibril Tamsir Niane; e Xala, do senegalês Ousmane Sembene.

Sobre as publicações, Fonseca finaliza: "julgo que são muito mais de 50 autores aqueles que nasceram através do Inald”.

\subsection{2 - Leitor e circulação}

A rede de ações em torno da leitura tinha, no Inald, assim como na União, alguns destinos certos. Fonseca lembra que o Instituto trabalhou para levar o livro a "fábricas, escolas, em unidades militares, às frentes de combate inclusive", além das bibliotecas das províncias e salas de leitura.

A criação de ENDIPU, distribuidora pública de livros, em 1979, teve o objetivo de desconcentrar as atividades do Inald. Foi ela que assegurou a distribuição dos títulos editados pelo Instituto a todo o país, por meio de livrarias próprias, fazendo circular o que era produzido em Luanda. Esta ação era completada com a distribuição feita pela EDIL (Empresa Distribuidora Livreira, do MPLA), além de uma distribuidora privada.

Mais do que a edição de livros, o Inald trabalhou de maneira insistente em atividades para a promoção da leitura, sendo que duas se destacam: a realização de concursos literários e o já citado Jardim do Livro Infantil, por meio do qual se realizavam palestras e conferências sobre literatura infantil, para além de atividades recreativas com crianças. "Mais de trinta anos após a sua criação em 1979, o Jardim do Livro é ainda hoje uma realidade em todo o país", destaca Boaventura.

Com os concursos literários, o Inald tinha o objetivo claro de acompanhar o surgimento de novos autores e obras. O emblemático Quem me dera ser onda, de

\footnotetext{
${ }^{31}$ A coleção, publicada em 1982, reuniu pelo selo do Inald seis autores e doze obras. As ilustrações eram do artista plástico Antonio Dominguez.
} 
Manuel Rui, por exemplo, foi uma das obras reveladas pelo Instituto. Antonio Fonseca cita o Concurso Literário Camarada Presidente, que possuía três categorias - prosa poesia e literatura infanto-juvenil -, e outras ações que, no seu entendimento, fortalecia a promoção da leitura no país:

Criamos o prêmio de revelação António Jacinto, foi criado mais tarde o prêmio de Ensaio Mário Pinto de Andrade e o Prêmio de Literatura Infantil Jardim do Livro Infantil. Relançamos também o concurso Vamos Escrever, Desenhar e Pintar, realizado em parceria com as escolas do ensino primário do país. As parcerias com a Direção Política do Exército, com o Ministério de Educação, com a Brigada Jovem de Literatura, que se multiplicou pelo país, com a União Nacional dos Trabalhadores, a UNTA, e com a Rádio Nacional, com a Televisão Pública e com o Jornal de Angola, foram muito úteis a todo o trabalho, tal como os prêmios e concursos literários promovidos por essas instituições. ${ }^{32}$

No plano internacional, o Inald, assim como a União, marcava presença em feiras de livros, como as de São Paulo, Frankfurt e Moscou, levando a literatura angolana a outros continentes.

Boaventura cita as Brigadas Jovens de Literatura como um importante mecanismo para a ampliação de um público leitor, destacando também que no "seio das unidades militares e nos centros populares de cultura implantados em todas as províncias, incentivava-se, igualmente, a juventude à leitura.” Para ele, um aspecto particular da literatura angolana favoreceu uma aproximação com o leitor local: o tema da luta de libertação nacional em todas as suas vertentes - racismo, dominação, exploração e resistência, que era frequente nos primeiros anos da independência. Boaventura acredita que esses "temas literários mais apelativos" atraíam o público, de maneira que os escritores mais lidos no período teriam sido Agostinho Neto, António Cardoso, José Luandino Vieira, Pepetela, Manuel Pedro Pacavira, Uanhenga Xitu e Arnaldo Santos. Ele assinala que a partir de 1980 esse cenário sofre algumas mudanças, com uma maior diversidade temática na literatura angolana.

Para Fonseca, a formação de um público leitor foi orientada, pois “desde a independência foi cultivado o sentido da importância da literatura na edificação da angolanidade. A avidez pelo conhecimento da literatura angolana e pelo conhecimento de África através da literatura foram fatos indesmentíveis”. Quando lhe indago quem

32 Os prêmios citados, exceto o Camarada Presidente, que será abordado em mais detalhes posteriormente, foram criados depois de 1991, período que ultrapassa a abrangência dessa pesquisa. 
seriam esses leitores, a resposta é abrangente: "Os leitores foram todos: novos e velhos, civis e militares, homens e mulheres, intelectuais e operários... na casa mais humilde era possível encontrar livros", esta última uma argumentação presente em cada interlocutor deste trabalho, nos levando a repensar o local do livro na sociedade angolana.

\section{3 - Prêmios literários}

Os prêmios podem celebrar a literatura, assim como desenvolver e estimular a atividade literária, descobrir novos talentos e fomentar a leitura. Eles garantem visibilidade a obras e a autores, não raro confirmando um prestígio público que o escritor já deteria, conferindo-lhe um reconhecimento cultural e social.

Uma das ações empreendidas para promover a literatura tanto pela União quanto pelo Inald, citadas por todos os interlocutores, foram os prêmios literários. Eles certamente, como em outros países, operaram como instâncias das mais importantes na canonização de autores e obra em Angola.

A União manteve pelo período analisado o Prêmio Nacional de Literatura, que foi criado em 1979 e, no ano 2000, foi incorporado pelo Ministério da Cultura, que o transformou no Prêmio Nacional de Cultura e Artes, ampliando as categorias para além da área literária.

O sucinto regulamento do prêmio (Anexo Q), composto de oito artigos, define em seu artigo primeiro que a União "institui um prêmio anual destinado a galardoar o melhor livro de poesia, ficção ou ensaística de autor angolano, publicado na República Popular de Angola no período compreendido entre 1 de dezembro da cada ano e 30 de novembro do ano seguinte, denominado Prêmio Nacional de Literatura”. Chama a atenção que o regulamento não indique outros qualificativos para a obra a ser reconhecida. Como prêmio para o vencedor, fala apenas em "simbolismo da distinção", além da importância de 50 mil quanzas.

O júri era composto por três nomes indicados pela União, um pela Secretaria de Estado de Cultura e outro pelo Departamento de Cultura e Desportos do MPLA, estando o governo, portanto, presente na avaliação das obras.

O primeiro homenageado a receber a láurea foi Agostinho Neto, pelo "alto valor literário, humano e revolucionário" de sua obra Sagrada Esperança, conforme consta na ata da premiação (Gazeta Lavra \& Oficina $n^{\circ} 15$, dezembro de 1979). O prêmio 
começou a ser entregue em 1979, ano da morte de Neto, mas essa primeira edição é retroativa a 1975, data da independência, de maneira que o poeta e presidente mereceu a primeira distinção, relativa aos primeiros cinco anos da república.

Entre os demais premiados, é de se destacar o fato do autor Pepetela ter sido por duas vezes condecorado: em 1980, por Mayombe, e em 1985, por Yaka, dois romances que, abordando momentos distintos e por diferentes estratégias narrativas, têm Angola e as questões anticoloniais como protagonistas. Na ocasião em que venceu por Mayombe, a ata da premiação qualifica o romance como de "interessante construção dramática, linguagem simples e expressiva, verdade dos caracteres e situações e humana compreensão dos conflitos, o que tudo faz dele excelente fonte de conhecimento e de sã pedagogia" (Gazeta Lavra \& Oficina $n^{\circ} 34 / 39$, julho/dezembro de 1981). Os elementos para os quais o júri chama a atenção provocam a convenção da ficcionalidade, atribuindo à obra sobre um grupo de guerrilheiros que, no início dos anos 70, atuava na floresta do Mayombe, na região de Cabinda, um caráter quase didático.

Outra premiação que contou com a participação da UEA é o Grande Prêmio Sonangol de Literatura. Criado pela Sociedade Nacional de Combustíveis de Angola em 1987, o prêmio tem o "objetivo de valorizar e reconhecer a criatividade dos escritores angolanos, em estreita colaboração com a União de Escritores Angolanos (UEA)". Além de premiação em dinheiro, o prêmio oferece "visibilidade e promoção da obra e carreira do autor" (http://www.sonangol.com.ao acessado em 11 de fevereiro de 2017).

À União coube a gestão do prêmio, conforme seu artigo $6^{\circ}$ : “O Grande Prémio Sonangol de Literatura será gerido por uma comissão de gestão composta por cinco (5) membros, sendo três (3) nomeados pela Sonangol e dois (2) nomeados pela UEA.” As obras que podem se inscrever são aquelas em língua portuguesa, "que se refiram aos fatos, acontecimentos ou personalidades, ocorridos ou relacionados com o território nacional dos concorrentes." Entre os critérios a serem avaliados estão "o seu valor educativo e patriótico".

Implantado já na segunda metade da década de 1980, o prêmio traz nomes que ainda não figuravam, ao menos com tanta força, no cenário literário angolano. Exemplo disso é o primeiro vencedor José Luis Mendonça com seu Gíria de Cacimbo, que, apesar de já ter sido premiado em 1981 pelo Inald, pertence a uma geração posterior a dos escritores identificados com a guerrilha, denominada, como já abordado anteriormente, de “geração das incertezas". Em 1989 é a vez de José Eduardo Agualusa, com A Conjura, sua primeira obra a despontar na paisagem literária do país. 
Já o Inald criou, em 1980, o Concurso Literário Camarada Presidente, que possuía as seguintes categorias: prosa de ficção (Prêmio Caminho das Estrelas), poesia (Prêmio Sagrada Esperança) e literatura infanto-juvenil (Prêmio Manguxi). Homenagem a Agostinho Neto, os nomes dos dois prêmios são títulos de duas de suas poesias, enquanto o último é um de seus apelidos, seu nome em quimbundo. Na década de 1990 todos os gêneros foram concentrados no Prêmio Sagrada Esperança, que ainda hoje existe. O primeiro autor a receber esta premiação, em 1980, foi Manuel Rui, com Quem me dera ser onda.

O Sagrada Esperança busca, conforme seu regulamento, "desencadear, de forma sistemática, uma nova vaga de legitimação discursiva para o conhecimento, consolidação e defesa da angolanidade" e "promover os valores literários inerentes à produção e à reprodução do imaginário cultural das comunidades sócio-culturais que constituem o povo angolano e identidade cultural angolana".

É interessante notar, avaliando o regulamento tanto do Prêmio Sonangol quanto o do Sagrada Esperança, esboçados já em data não tão próxima à da independência, que os valores da angolanidade e a busca pelo conhecimento da nação persistem como critérios para o juízo e a validação de uma obra literária.

\section{4 - O projeto literário e seu leitor - um balanço}

Observando o posicionamento e as ações tanto da União dos Escritores quanto do Inald, é possível vislumbrar que o lugar reservado à literatura no projeto da nação angolana que emergiu em 1975 era de grande prestígio. A ela coube o intenso trabalho e a responsabilidade de redesenhar os contornos da nação. As duas instituições que lideraram esse processo, avaliamos, tiveram atuação homogênea, embora uma oficialmente representasse o Estado, enquanto a outra se dedicasse a representar os escritores do país, o que não impediu que assumisse tarefas de apoio à área cultural e educacional do governo.

Em linhas gerais, o projeto levado a cabo pelas duas instituições analisadas previa que a literatura consolidasse a ideia de nação traçada nos anos de luta anticolonial. Se, como afirma Benedict Anderson, imprensa e livros podem estar a serviço do nacionalismo, Angola parece ter sido um caso exemplar, ao menos no que diz respeito à intenção. Embora as formulações de Anderson busquem dar conta da 
emergência do nacionalismo na Europa, ao mostrar como jornais e romances contribuem para que os habitantes, a partir da ideia de simultaneidade, sintam-se pertencentes a uma mesma comunidade ${ }^{33}$, oferece pistas para a compreensão das relações entre literatura e nação em Angola. Anderson classifica a leitura de um jornal, por exemplo, como uma "cerimônia de massa", pois cada participante deste ato tem a consciência de que ele está sendo repetido por milhares de outros indivíduos ao mesmo tempo, indivíduos estes que lhe são totalmente desconhecidos, apesar da convicção de sua existência. "Ao mesmo tempo, o leitor do jornal, ao ver réplicas idênticas sendo consumidas no metrô, no barbeiro ou no bairro em que mora, reassegura-se continuamente das raízes visíveis do mundo imaginado na vida cotidiana (ANDERSON, 2006, p. 68)".

Em um país com múltiplas etnias e línguas, a busca por um atalho que trabalhasse em prol da unificação do território desembocou na literatura, que favoreceu a ideia de uma Angola "imaginada" em língua portuguesa, em uma escolha que, calculada ou fortuita, se revelou eficaz. Como afirma Lilia Schwartz na apresentação do livro de Anderson, "não se imagina no vazio e com base em nada. Os símbolos são eficientes quando se afirmam no interior de uma lógica comunitária afetiva de sentidos e quando fazem da língua e da história dados 'naturais e essenciais'; pouco passíveis de dúvidas e de questionamento" (SCHWARTZ in ANDERSON, 2006, p. 17).

Nesse projeto, vemos ainda como os valores nacionais são exaltados ou convocados em distintas instâncias: no estatuto da UEA, que privilegia os trabalhos que aprofundam o estudo das tradições angolanas; nos regulamentos dos prêmios, que preconizam obras que exploram a angolanidade; nos discursos do presidente Agostinho Neto, que atribui à literatura um papel de edificação da nação. Falar de Angola, seguir descobrindo Angola, era, mais que desejável, imperativo.

A literatura portanto estava, em grande medida, a serviço do Estado. A perspectiva de que a literatura tinha o papel de respaldar a reconstrução nacional era largamente disseminada. Uma das seções da Gazeta Lavra \& Oficina, publicação oficial da União, era a de "inquérito a autores", que se propunha a entrevistar os escritores membros da entidade. As perguntas se repetiam a cada edição, e entre elas é interessante

\footnotetext{
33 Anderson usa a expressão comunidades imaginadas para, em sua tentativa de definir uma nação, explicar que os membros de um país jamais terão qualquer relação com a maioria de seus companheiros com quem partilham a nação, mas é viva entre eles a ideia de uma comunhão. Ao se valer da palavra imaginada, o autor não está interessado em definir as nações por uma presumível falsidade ou autenticidade, mas em entender como elas são imaginadas (ANDERSON, 2006, p. 32).
} 
notar que, ao menos nos 13 números a que tivemos acesso, constavam as seguintes indagações: Que pensa do papel desempenhado pela nossa literatura na luta de libertação nacional? Que papel pode desempenhar na reconstrução nacional? Para que serve um escritor no nosso país?

Vejamos como nas respostas, todas elas de escritores ligados à União, esse ideal aparece:

A literatura angolana foi pilar válido na luta da nossa independência. (...) Foi sua ação que deu a saber ao mundo tudo quanto se passava no nosso país. A literatura é reduto de luta e continuará a sê-lo em todos os lugares da vida dos povos. (Raúl David - Gazeta $\mathrm{n}^{\circ} 13$ - outubro de 1979, p. 12)

$\mathrm{O}$ escritor serve para indicar o melhor caminho à humanidade. O escritor terá de ser nacional e universal, só assim ele intervirá no progresso do mundo. Terá de constantemente arranjar parâmetros entre o belo e o feio, entre o bem e o mal (...). (Maria Eugénia Neto - Gazeta 14, novembro de 1979, p. 3)

Neste momento um escritor luta tanto quanto as FAPLA pela defesa das conquistas da nossa revolução. $O$ escritor pode deformar ou formar a mentalidade dos leitores e portanto contribuir para a consolidação de uma forma qualquer negativa ou positiva de consciência social (e nacional). Cabe ao escritor lutar pela objetividade das coisas que fazemos, explicar a razão delas, indicar as saídas que resultaram das diferentes práticas sociais, bater-se pela ideia justa, progressista e atacar todas as ideias reacionárias que entravam o caminho do nosso povo para o estádio superior onde pretende chegar. (Henrique Abranches Gazeta Lavra \& Oficina, $n^{\circ}$ 40/45, jan/jun de 1982, p. 2)

Para tudo e para nada (serve um escritor). Para que serve um abacateiro, ou para que serve uma vassoura de mateba? Ninguém peça a um abacateiro que dê laranjas. Ninguém peça a uma vassoura que voe entre as coxas de uma bruxa, ninguém pede a um feiticeiro a magia dos sues milongos. Ao escritor, peçam tudo, mesmo o impossível, que o impossível surgirá. (Antonio Jacinto - Gazeta Lavra \& Oficina $n^{\circ} 34$ ao 39, 1981) 
Como se sabe, não há praticamente escritor angolano que não estivesse ou esteja metido na luta de libertação nacional. Com maior ou menor adesão pessoal, com maior ou menor grau de lucidez possível. Mas não exageremos: o seu papel de testemunho é grande (e ainda é preciso vir a público muito suor desses anos), o conhecimento massivo de seus trabalhos foi (não por culpa dos autores) diminuto, mesmo considerando o analfabetismo do nosso povo. É urgente publicar-se ainda mais. De qualquer forma, nas áreas urbanas cumpriu um papel positivo de consciencialização, ainda a estudar e a definir a grandeza e a profundidade. (António Cardoso - Gazeta Lavra \& Oficina $\mathrm{n}^{\mathrm{o}} 16$, janeiro de $1980 ;$ p. 4)

Serve para ... libertar (um escritor em nosso país) (...) Um profundo papel didático, ético, combatendo o racismo, o tribalismo, o regionalismo, pois sim, mas também o carreirismo, o oportunismo, e muitos preconceitos da moral burguesa (pequena ou não) difíceis de extirpar. O rumo é uma sociedade sem classes, o socialismo científico. (António Cardoso - Gazeta Lavra \& Oficina $n^{\circ} 16$, janeiro de $1980 ;$ p. 5)

Creio que a literatura nacional é elemento indispensável, tão importante como outro qualquer, para a consolidação da independência. É um fator que ajuda a aumentar a unidade nacional, por ser veículo de conhecimentos de situações, modos de vida e de pensar, entro o país. (...) Penso que é a literatura, tomada como parte da cultura nacional, que cria (ou sistematiza a criação) duma consciência própria de um povo e que se distingue assim dos outros. Pode ser exagero (é caso para se discutir), mas afirmo que não há, não pode haver, a criação de um país verdadeiramente independente sem uma literatura nacional própria, que mostre ao povo aquilo que o povo sempre soube: isto é, que tem uma identidade própria. (Pepetela Gazeta Lavra \& Oficina ${ }^{\circ} 5$, fevereiro de 1979, p. 4)

É de grande transparência, nesses discursos, que o papel da literatura e do escritor deva em muito ultrapassar a fruição estética. Educar o leitor, apontar caminhos, servir ao projeto do Estado, contribuir com a revolução, fortalecer a identidade nacional, libertar o homem são algumas das missões atribuídas à instância literatura. São pouquíssimas as ressalvas, nesta breve amostra, do compromisso entre literatura e liberdade criativa. Excetuando-se a fala do poeta António Jacinto, que pressupõe que o papel do autor é criar (Ao escritor, peçam tudo, mesmo o impossível, que o impossível surgirá), as demais insistem na função missionária da literatura e de seus operadores, os escritores. 
Esta tarefa legada à literatura não é especificidade de Angola, mas situação quase inescapável nos momentos de formação de uma nação. Antonio Candido nos fala que "o nacionalismo artístico não pode ser condenado ou louvado em abstrato, pois é fruto de condições históricas, - quase imposição nos momentos em que o Estado se forma e adquire fisionomia nos povos antes desprovidos de autonomia ou unidade" (CANDIDO, 2012, p. 29).

$\mathrm{Na}$ esteira desses pensamentos, é compreensível que a literatura e o livro tenham se transformado em uma questão de Estado. Seja diretamente, por meio das ações do Inald, ou por intermédio dos subsídios que oferecia à UEA de um lado, e de outro pelo apoio que dela reivindicava, o governo destinou esforços para garantir que os produtos literários fossem elaborados, distribuídos e lidos. A própria criação do Inald, um instituto voltado parar o livro, reflete essa valorização.

No que tange ao leitor, depreendemos que as instituições não produziam para um público que já existia - a pequena elite de intelectuais que até a independência constituía o grupo de leitores no país -, mas estavam em busca de formar um leitor, de criar condições para que esse leitor surgisse. São muitos os indícios desse movimento: a aposta em uma literatura infantil, forjando desde a infância o gosto pela leitura; a destinação de livros para o Exército Nacional (Luandino nos fala que, dos cinco mil livros publicados, ao menos dois mil seguiam para a FAPLA, distribuídos junto com a ração e as munições), em um momento em que, em plena guerra civil, o Exército é instituição de grande relevância, formado por indivíduos das mais diferentes origens, citadinos e camponeses, jovens e adultos; a realização das campanhas de alfabetização, que pretendiam introduzir a população no universo da palavra escrita; a inclusão de autores angolanos nos livros didáticos; e os incentivos financeiros, via subsídio, para que os livros nacionais circulassem com facilidade. Essas ações revelam a preocupação com a formação de um público leitor, embora esse leitor seja relativamente tutelado.

Assim, o leitor que parece estar no horizonte da União e do Inald não era necessariamente um leitor de literatura voltado para a apreciação das obras que se produzem em todo o mundo. Mas sobretudo um leitor semeado para desenvolver o gosto pelos temas e causas locais, um leitor que fosse, em alguma medida, endereçado ao socialismo. A aposta em um livro didático, como vimos, que privilegiava um recorte ideológico conferido por textos de autores oriundos de nações que partilhavam de um projeto político semelhante, é uma mostra disso. Como nos diz António Fonseca, que dirigiu o Inald, a formação de um público leitor foi orientada, pois "desde a 
independência foi cultivado o sentido da importância da literatura na edificação da angolanidade. A avidez pelo conhecimento da literatura angolana e pelo conhecimento de África através da literatura foram fatos indesmentíveis".

Havia uma intenção de fazer da literatura um objeto de prestígio, mas não o prestígio do livro sacralizado numa biblioteca, da alta cultura. E sim uma distinção advinda do caráter utilitário da literatura, que oferecia esclarecimentos, favorecia uma identificação e pressupunha uma ação. Fonseca lembra que o Instituto trabalhou para levar o livro a "fábricas, escolas, em unidades militares, às frentes de combate inclusive", revelando o quão esse movimento do livro, de sair das prateleiras e ganhar as ruas, foi desejado.

Eugénio Ferreira, em texto sobre a difusão do livro em Angola, compara o circuito dos livros nos países capitalistas, onde estariam a serviço do lucro, com aqueles de viés socialista, reiterando a ideia exposta da necessidade de circulação das publicações:

\begin{abstract}
Nos países socialistas, os escritores, os criadores em geral, estão em contato direto com as "massas", quer através do partido quer das suas próprias organizações privativas, profissionais ou culturais, quer, ainda pelo seu modo de existência. Paralelamente, é assegurada a mais larga distribuição direta do livro, sem restrições e sem mediações. O livro está em toda a parte. No escritório e no armazém. Na fábrica e na cantina. Na lavra e na oficina (Gazeta Lavra \& Oficina, março de 1979, p. 9).
\end{abstract}

Chama a atenção, no entanto, uma condição muitas vezes evocada e que contrasta com esse caráter utilitário do livro: a concepção de que a literatura está vinculada à felicidade. A ideia é marcante nos discursos de Agostinho Neto lembremos que nas coleções infantis da UEA encontramos a frase Nós queremos que os homens sejam cada vez mais felizes impressa em suas páginas iniciais - e volta-se para a face estética e não combativa da literatura. Esta parece ser uma constante do projeto literário em curso em Angola: a busca por um equilíbrio, ainda que tênue, entre as imposições do Estado e a liberdade criativa, entre uma literatura a serviço de uma causa política e aquela que irrompe para satisfazer uma necessidade outra.

O que não está em discussão, no entanto, é o fato dessa literatura estar ao alcance de todos. O projeto angolano é democrático no que diz respeito ao acesso ao livro, não deixando dúvidas sobre a vontade de popularização da leitura. O cenário nos remete para o texto Direito à literatura, de Antonio Candido, quando argumenta que o 
pressuposto dos direitos humanos é "reconhecer que aquilo que consideramos indispensável para nós é também indispensável para o próximo" (CANDIDO, 2004, p. 172). A literatura, para o autor, integraria a relação daqueles bens essenciais pois, se não garante a sobrevivência física do homem, trabalha pela sua integridade espiritual.

Não há povo e não há homem que possa viver sem ela ( $a$ literatura), isto é, sem a possibilidade de entrar em contato com alguma espécie de fabulação. (...) E durante a vigília a criação ficional ou poética, que é a mola da literatura em todos os seus níveis e modalidades, está presente em cada um de nós, analfabeto ou erudito, como anedota, causo, história em quadrinhos, noticiário policial, canção popular, moda de viola, samba carnavalesco (...) Ora, se ninguém pode passar 24 horas sem mergulhar no universo da ficção e da poesia, a literatura concebida no sentido amplo a que me referi parece corresponder a uma necessidade universal, que precisa ser satisfeita e cuja satisfação constitui um direito (CANDIDO, 2004, p. 174).

A ideia é afim àquela que Michèle Petit chega ao fim de seu estudo com jovens franceses frequentadores de bibliotecas:

Ouvindo-os, ouvindo aqueles que trabalham junto deles, compreendemos que a literatura, a cultura e a arte não são um suplemento para a alma, uma futilidade ou um monumento pomposo, mas algo de que nos apropriamos, que furtamos e que deveria estar à disposição de todos, desde a mais jovem idade e ao longo de todo o caminho, para que possam servir-se dela quando quiserem, a fim de discernir o que não viam antes, dar sentido a suas vidas, simbolizar as suas experiências (PETIT, 2009, p. 289).

Em Angola, percebemos uma tentativa de materialização desse direito: as redes de apoio, produção e circulação do livro foram pensadas para que a literatura não faltasse à população. No entanto, é preciso ressaltar, como nos alerta Petit, que esse direito não se configura apenas com a distribuição dos livros, mas está relacionado também ao conteúdo do texto literário:

Por meio da difusão da leitura, cria-se um certo número de condições propícias para o exercício ativo da cidadania. Propícias, necessárias, mas não suficientes. Mais uma vez, não sejamos ingênuos. Se existe uma leitura que auxilia a simbolizar, a se mover, a sair do lugar e a se abrir para o mundo, existe também uma outra que só conduz aos prazeres da 
regressão. E se alguns textos nos transformam, há uma grande quantidade que, na melhor das hipóteses, apenas nos distraem (PETIT, 2008, p. 101).

Cabe ainda, para além de discursos e intenções, depreender a forma como esse projeto se materializou observando os objetos produzidos - os livros -, seus números e outros indícios relevantes para uma história da leitura. Esses dados nos levam a uma tríade de autores de destaque que acaba por representar os pilares sobre os quais parece ter sido fundado esse projeto literário. Os escritores que obtiveram maior notoriedade no período em que nos propusemos analisar, entre 1975 e 1991, seja pelas altas tiragens de suas obras, pelos prêmios recebidos ou por ser dos mais editados são Agostinho Neto, Luandino Vieira e Pepetela. Observemos como cada um cumpre um papel distinto na paisagem literária angolana.

É de autoria de Agostinho Neto o livro mais vendido em Angola. Sagrada Esperança chegou a mais de 500 mil exemplares, tendo sido traduzido para diversos idiomas, entre eles o francês, o russo e o vietnamita. A trajetória poética de Neto é indissociável de sua trajetória política. Líder do MPLA e da luta anticolonial que veio a falecer enquanto exercia o cargo de primeiro presidente da nação independente, foi a figura em torno da qual se construiu o herói da revolução angolana ${ }^{34}$. Publicou apenas quatro obras, mas seu Sagrada Esperança acabou por se configurar, como explica Pires Laranjeira, como o "texto poético épico da angolanidade" (LARANJEIRA, 1995, p. 92). O peso da obra de Neto deve ser entendido em seu complexo estético e político.

Se considerarmos o autor mais editado pela UEA, nos deparamos com Luandino Vieira. Escritor de prestígio, foi inegavelmente o prosador mais disruptivo dos anos que rondam a independência. Ainda que suas obras possam ser avaliadas como comprometidas com a luta anticolonial, é no campo estético que ele inaugura uma tradição. Observemos o que Rita Chaves fala sobre a prosa de Luandino, em seu Formação do Romance Angolano:

\footnotetext{
${ }^{34}$ São muitas as referências, construções e homenagens a Neto que vão ao encontro dessa ideia, tanto no campo literário quanto extra-literário. Fiquemos com esse trecho da oração fúnebre proferida por Lúcio Lara, um dos fundadores do MPLA e dos mais importantes quadros do partido, na ocasião da morte de Neto, que sintetiza o papel do líder em Angola: "Habituamo-nos, Comandante-em-Chefe, sob o Teu comando, a não acreditar na derrota e a forjar vitórias para o nosso Povo. A certeza da vitória eras Tu, que sabias sorrir diante do perigo, que sabia criar com os olhos secos, que não conhecias nem o medo nem a dúvida diante dos objetivos que desde cedo foram traçados (...) Chefe incontestado de um Povo heroico, tornaste-te o Pai de todos os filhos angolanos, o Filho de todas as Mães de Angola" (Gazeta Lavra \& Oficina, $\mathrm{n}^{\circ}$ 11-12, agosto/setembro de 1979).
} 
No plano da narrativa surge, então, a obra de José Luandino Vieira, que, ao assinalar uma mudança de perspectiva no ato de narrar, provoca alterações extraordinárias no interior do sistema literário angolano. Em sua obra, o poderoso lastro da experiência se vai enformando, e o texto literário faz-se espaço onde se transfiguram produtivamente as sombras da realidade concreta. Com um excepcional trabalho de depuração da linguagem, ele mistura as pontas de uma identidade em conquista e consegue abstrair a circunstância imediata dos domínios do cotidiano para convertê-la em material estético (CHAVES, 1999, p. 159).

Outro autor que se destacou por ser largamente editado e que foi reconhecido duas vezes em curto período de tempo com o Prêmio Nacional de Literatura, oferecido pela União, é Pepetela. Integrante de frentes guerrilheiras durante a luta anticolonial, o escritor flerta, em grande parte de suas obras, com a história, sendo reconhecido por sua filiação à corrente do romance histórico. É um autor que traz Angola para a cena, que busca recontar sua história, tratar dos temas da terra e resgatar sua genealogia, sem se furtar a tecer críticas às situações vivenciadas no país. Sobre seu projeto literário, Donizeth dos Santos, em sua tese de doutorado sobre as narrativas de fundação de Pepetela, nos diz:

A escrita que ele faz da construção da nacionalidade angolana é permeada por um questionamento constante acerca das estruturas de poder dessa sociedade que se está a construir, num contínuo entrelaçamento entre ficção, história e política. Dessa forma, o projeto literário de Pepetela possui uma dupla face: primeiramente ele tematiza a formação da nação angolana, reescrevendo a história do país através da ficção, dando voz a tudo que ficou silenciado nos desvãos da história colonial, mas ao mesmo tempo questiona todo esse processo, inserindo no texto literário uma crítica contundente tanto às estruturas de poder colonial quanto às novas estruturas de poder que se estão a construir (SANTOS, 2013, p. 176).

Esses três autores, cujas obras resumidamente tentamos explorar, acabaram por entrar para o cânone da literatura angolana ${ }^{35}$ e revelam algo singular do projeto literário:

\footnotetext{
${ }^{35}$ Entre os múltiplos mecanismos que envolvem a canonização de autores e obras, Roberto Reis (1992) nos alerta que "o critério para se questionar um texto literário não pode se descurar do fato de que, numa dada circunstância histórica, indivíduos dotados de poder atribuíram o estatuto de literário àquele texto (e não a outros), canonizando-o." Na sociedade angolana, não há dúvidas de que UEA e Inald eram instituições dotadas do poder necessário para consagrar determinados escritores. Não à toa dois dos três autores citados foram posteriormente premiados com a maior distinção em língua portuguesa pelo
} 
do complexo mosaico que é a instituição literatura e que foi a angolana de então, valorizou-se uma tríade fundada no rigor estético, no retrato da angolanidade e no compromisso com a luta política e o Estado angolano.

Vejamos no capítulo seguinte como os leitores que vivenciaram este período e foram os receptores desta literatura leram e significaram esses e outros autores e obras, a partir das reconstituições de suas práticas de leituras, que confirmam, se chocam, complementam ou estão além desse projeto que tentamos mapear.

conjunto da obra, o Prêmio Camões. Pepetela recebeu a láurea em 1997. Em 2006 foi a vez de Luandino Vieira, que recusou a premiação alegando motivos pessoais. Pepetela foi o primeiro autor africano a ser cobrado no vestibular de ingresso da maior universidade do país, a Universidade de São Paulo, que passou a adotar o romance Mayombe em 2016. Já a obra Luuanda, de Luandino Vieira, foi exigida pela Fundação Cásper Líbero em 2010. 


\section{4 - LEITORES REAIS}

"Escrita é expressão, leitura é impressão. A escrita é pública; a leitura, privada. A escrita é limitada; a leitura, infinita. A escrita congela o momento. A leitura é para sempre”.

As definições em torno da escrita e da leitura feitas por Steven Roger Fischer em seu História da Leitura (2006, p. 8) referidas como epígrafe deste capítulo sugerem diferenças consistentes entre o binômio escrever-ler. A segunda ação é particular, portanto múltipla, e, ficando no campo das impressões, certamente é um tanto fugidia. Essas distinções são também, em alguma medida, explicativas do movimento feito nessa dissertação.

No capítulo anterior, ao examinarmos as instâncias de produção representadas pela UEA e o Inald, nos detivemos na primeira fração deste par, observando, sobretudo do ponto de vista da escrita, quais as transformações pelas quais passou a literatura angolana com a independência do país, que não encontram precedentes na história de Angola. Marcada pela larga publicação de autores angolanos, por ações que promoveram a maior circulação do livro e pela tentativa de inclusão de grande número de pessoas no universo da escrita, a paisagem literária angolana foi definitivamente alterada. É certo que naquele capítulo buscamos também encontrar o leitor que estava no horizonte dessas instituições, mas estávamos, ainda, no campo da produção.

Neste quarto e último capítulo, buscamos mergulhar no exclusivo universo da leitura, dando voz ao leitor real. Essa dinâmica não será feita a partir de outros elementos, mas deixando sua própria voz, por tanto tempo silenciada, emergir deste emaranhado de textos, atores e instituições que compõem um sistema literário. Se a leitura é fugidia, como sugere Fischer e afirma $\operatorname{Darton}^{36}$, uma maneira de tentar capturála é inquirindo os responsáveis por esta ação: os leitores.

O que nos propusemos fazer, portanto, foi reconstruir as memórias de leituras de angolanos que vivenciaram o período analisado, tentando rastrear os impactos que o projeto, em muito encabeçado pela União e pelo Inald, ocasionaram em suas trajetórias

\footnotetext{
${ }^{36}$ Lembremos que o teórico destaca, dentre todas as ações que envolvem o circuito do livro, a leitura como a mais desafiadora de se mapear (DARNTON, 2010).
} 
e os diálogos que esses leitores estabeleceram com a literatura de maneira geral e com o que surgiu em Angola após a independência. Se o leitor é figura constantemente evocada para sustentar argumentos em torno da literatura angolana - como vimos nos capítulos anteriores, são correntes afirmações como "havia muita euforia em torno do livro, todos queriam ler" ou "a juventude queria ser como os guerrilheiros e por serem escritores, havia muita identificação" ou ainda "havia muita curiosidade, por isso se buscava os livros" - conversar diretamente com leitores revela-se uma estratégica legítima e mais eficiente na tentativa de ajustar seu lugar na trama da literatura angolana. Recorrer a essas fontes é ainda uma maneira de aproveitar a oportunidade de reconstruir uma história com seus atores diretos, o que em algumas décadas poderá ser inviável.

A abordagem utilizada, das entrevistas qualitativas, não se preocupa em oferecer uma amostra representativa, mas resgatar extratos da realidade, considerando que cada narrativa tem sua relevância. As informações coletadas por meio dessas entrevistas abertas, em que o fio condutor é oferecido pelo entrevistado, permitem que o pesquisador produza uma leitura que não se expressa em números ou percentuais, mas se funda em narrativas, impressões, comportamentos e símbolos. A tentativa, então, é de atribuir o papel de narrador a quem comumente está fadado ao silêncio.

A entrevista qualitativa, vale insistir, é um dos principais instrumentos a serviço da investigação social, consistindo em uma técnica que permite analisar as marcas que determinadas experiências deixam nas pessoas. Ela busca averiguar as questões que os indivíduos compartilham uns com os outros ou que induzem a um comportamento semelhante devido ao fato de dividiram um mesmo problema, uma mesma posição social, um espaço físico ou sistema cultural (RUBIO \& VARAS, 2004). Sua leitura, no entanto, não resultará em estatísticas, mas está interessada na compreensão dos fenômenos levando em conta o horizonte dos entrevistados.

Dentre as diversas técnicas do método qualitativo, nos apropriamos daquele chamado história de vida, mas nos permitimos um recorte que privilegiou as histórias de leitores. Por esta seara, é possível tentar capturar aquilo que acontece na intersecção entre o que é pessoal e o que é social. Como nos explica Ecléa Bosi (1994), este tipo de registro alcança uma memória individual que também não deixa de ser social, familiar e grupal, ficando na fronteira entre maneiras de ser do indivíduo e de sua cultura. $\mathrm{O}$ pesquisador italiano Alessandro Portelli, que se ocupou em sistematizar os usos, vantagens e limitações do método da história de vida, afirma que as entrevistas nos 
contam mais sobre significados que sobre eventos e que elas "revelam eventos desconhecidos ou aspectos desconhecidos de eventos conhecidos: elas sempre lançam nova luz sobre áreas inexploradas da vida diária das classes não hegemônicas" (PORTELLI, 1997, p. 31).

Se seguirmos na chave da liberdade arbitrária que, de acordo com Chartier (1994), teria o leitor, limitado de um lado pelas convenções de sua comunidade e de outro pelas formas materiais do texto, este é o momento de tentar captar o quinhão de autonomia que cabe ao leitor ao enfrentar um livro. É ainda uma forma de, abordando a leitura em Angola, contribuir com a história mundial da leitura, que se ocupa de tentar responder quem leu o quê e, sobretudo, em que condições.

A antropóloga francesa Michèle Petit já foi citada algumas vezes nesta dissertação. O que importa explicitar neste momento é que o seu trabalho, publicado num pequeno e precioso livro intitulado Os jovens e a leitura - uma nova perspectiva, é, desde o início, inspiração para esta investigação. A autora desenvolveu uma série de trabalhos que preconizam a relação entre o sujeito e os livros, privilegiando sobretudo a experiência do leitor. $\mathrm{O}$ estudo em questão é resultado de uma pesquisa em bibliotecas periféricas da França, frequentada por jovens marginalizados, muitos deles imigrantes, já exposto ao longo desta dissertação. Ao entrevistar esses jovens, Petit coleta narrativas em que o livro e a leitura são protagonistas, contribuindo para que esses jovens, ela conclui, tornem-se também protagonistas de suas histórias.

Estou convencida de que a leitura, em particular a leitura de livros, pode ajudar os jovens a serem mais autônomos e não apenas objetos de discursos repressivos ou paternalistas. E que ela pode representar uma espécie de atalho que leva de uma intimidade um tanto rebelde à cidadania (PETIT, 2008, p. 19).

Petit coordenou uma equipe em um trabalho financiado pelo Ministério da Cultura francês que ouviu noventa jovens, em entrevistas que, de acordo com ela, muitas vezes duraram mais de duas horas. Como ela explica, "situar-se do lado dos leitores requeria também uma metodologia. Mais uma vez, foi do lado da singularidade, não da representatividade, que situamos esta pesquisa". Assim, o grupo se dividiu para ouvir um a um os jovens, aqueles "cujas vidas, num momento ou noutro, em uma esfera ou em outra, haviam mudado devido a uma biblioteca".

Conversar individualmente com nossos interlocutores, pensando na singularidade de suas trajetórias, em como estabeleceram sua relação com o livro e com 
a literatura angolana, são as ideias que o trabalho de Petit estimulou, tendo em vista a escuta acolhedora e a profundidade dos relatos que, justamente por isso, conseguiu obter.

Partindo desse modelo ideal, cabe explicitar como se deu a coleta dos dados, ressaltando que o plano inicial de viajar a Luanda para, além da pesquisa de acervo, poder agendar encontros pessoais com os leitores, não foi executado. Diante desta impossibilidade, a internet acabou por ser uma grande aliada, tanto para a localização das fontes quanto para os momentos de interlocução. Foram entrevistados quatro leitores, em conversas que se deram pela internet. Duas delas foram via mecanismos que permitiam um diálogo em tempo real, o que se revelou bastante produtivo, pois foi possível seguir o tom oferecido pelo entrevistado, em conversas que chegaram a duas horas de duração. As outras duas foram via mecanismos mais estanques, em que as perguntas foram enviadas todas juntas, em um questionário. De qualquer maneira, essas conversas foram retomadas para o esclarecimento de algumas respostas e feitura de novas perguntas, o que ofereceu melhor dinâmica à interação.

O anseio maior para esta seção era contar com uma multiplicidade de vozes, encontradas em pessoas com diferentes perfis, interessando-nos mais a diferença social, de maneira que pudéssemos apreender como o projeto literário angolano ecoou não apenas naqueles que já pertenciam a um universo letrado. Porém, como relata Patrícia Trindade Nakagome em sua tese de doutorado acerca da visão do leitor formado pela crítica em contraposição ao leitor real, as pesquisas que envolvem entrevistas ou histórias de vida não discutem em profundidade os critérios para seleção dos sujeitos. "Em geral, são selecionados aqueles que se disponibilizam a participar" (NAKAGOME, 2015, p. 171). Este foi o caso dela e também o nosso. A distância geográfica e também o silêncio que muitas vezes marca os sujeitos que vivenciaram a experiência de um país de partido único foram alguns dos fatores limitantes, que impediram uma maior heterogeneidade dos entrevistados.

Assim, embora a pesquisa tenha se realizado em condições diferentes das inicialmente idealizadas, e obviamente em muito distante na dimensão do estudo coordenado por Petit, tendo em vista a própria natureza das duas investigações, cremos que ela guarda o que nos foi mais caro em todo o nosso trajeto: ouvir leitores reais, sem intermediários, e permitir que suas histórias pessoais com o livro e a literatura emergissem. 
Entre os tópicos abordados estavam as formas de acesso ao livro no período em questão; a temática da leitura em tempos de guerra; as práticas escolares e outras instâncias que aproximam os indivíduos da literatura, assim como outras atividades culturais que dialogam com a leitura; a forma como a literatura angolana foi significada para essas pessoas; suas preferências e gostos literários; a relação com literaturas de outros países; e outros aspectos para os quais, pelos fios da memória, nos levaram os angolanos atores desse processo.

$\mathrm{Na}$ reconstrução das narrativas, optamos por fazer sobressair as vozes desses atores, relatando, na medida do possível, sua história como nos foi contada, com poucas intervenções do entrevistador. Estamos cientes, no entanto, da impossibilidade de manter a total neutralidade ao fazer os relatos, salvo se optássemos pela exposição da íntegra da entrevista, o que tornaria a leitura menos fluida. Portelli afirma que

O resultado final da entrevista é o produto de ambos, narrador e pesquisador. Quando as entrevistas, como é frequentemente o caso, são arrumadas para a publicação, omitindo inteiramente a voz do entrevistador, uma sutil distorção tem lugar: o texto dá as respostas sem as questões, dando a impressão que determinado narrador dirá as mesmas coisas, não importando as circunstâncias (PORTELLI, 1997. P. 36).

Com consciência dessa limitação, explicamos por fim que, na organização das narrativas, escolhemos privilegiar um ordenamento cronológico dos fatos, com o intuito de auxiliar os leitores desta dissertação, que talvez não estejam familiarizados com as datas de importantes momentos de Angola, o que ocasionou pequenos ajustes na ordem em que as informações apareceram nos relatos. Feitas essas ressalvas, fiquemos, agora, na companhia destes leitores.

\section{$\underline{4.1}$ - Paula}

Paula passou a infância e a adolescência em Benguela, cidade do litoral sul de Angola, mas mudou-se para a capital na época de seu ensino pré-universitário. Morou no país até 1989, quando tinha 29 anos. Descendente de gerações de angolanos, ela hoje vive em Cabo Verde, mas mantém um constante fluxo, por meio de visitas e amizades, com seu país de origem. Na altura da independência, em 1975, ela tinha 15 anos. 
Hoje aos 57 anos, Paula rememora que na Benguela em que cresceu havia três livrarias. "E numa delas nós tínhamos crédito, o que era, obviamente, um luxo. Família de funcionários públicos com três filhos, o orçamento era sempre curto e os gastos controlados. Mas o meu pai tinha um contrato com a livraria, e nós podíamos ir buscar livros, e só se pagava no final de cada mês. Por isso comprávamos, e depois trocávamos com outros amigos."

A livraria não era a única fonte de livros na vida de Paula. A biblioteca de seu pai era quem principalmente the municiava: "O meu pai era grande leitor, e nós tínhamos muitos livros em casa e nada era proibido. $\mathrm{O}$ acordo era: se não perceberes pergunta-me que eu explico. Eu também seguia muito o caminho das irmãs mais velhas. Tudo o que elas liam eu acabava lendo também porque estava ali ao lado. Às vezes era sem dúvida fora do tempo, mas isso eu só percebi depois."

As primeiras recordações de leitura de Paula são textos da "era dos patinhas e mickeys". Ela não se lembra o que leu antes disso, "mas claro que deve ter havido alguma coisa". "Lembro-me também que passei dos patinhas para coleções dos 5 e dos 7 Enid Blyton, eu creio. Que se requisitavam na biblioteca da Câmara Municipal, que era uma espécie de central administrativa da cidade”, revelando aqui outra fonte para seus livros. Os livros de Blython, escritora britânica que viveu até 1968, traziam aventuras para crianças e adolescentes e foram muito populares, com tradução para dezenas de idiomas. Os 5 e os 7 são referência ao número de personagens que integram o grupo central das tramas, que protagonizaram diversos livros.

Na primeira infância Paula estudou em colégio privado, "porque era muito pequena e frágil, e os meus pais tinham medo de me mandar para a escola pública”. Mas como suas irmãs frequentaram a rede pública, ela afirma conhecer essa outra realidade.

Fez o ensino primário durante o regime colonial, em Benguela, que, segundo sua memória, era bastante exigente do ponto de vista da educação. "Para ver que Angola era, e é, o único país onde as pessoas não se entendem todas a não ser em português. Desde muito cedo, e refiro-me aos primeiros anos da primária, aprendíamos os clássicos. Os livros da primária tinham textos de Camões. Pequenos é claro, mas tinham. E traduções de fábulas de La Fontaine!” Nessa época, ela afirma não haver a inclusão de qualquer autor angolano no programa, "nem muito escondido".

Mas no liceu, que se cursa aproximadamente entre os 10 e 18 anos, os angolanos começaram a aparecer. No entanto, a situação parece ser muito pontual, pois ela se 
recorda sobretudo dos poetas locais, como Alda Lara, Aires de Almeida Santos, Ernesto Lara Filho. "Creio, e estou pensando nisto agora, que deveria haver uma certa liberdade de escolha por parte dos professores, porque amigos meus da mesma idade, mas de outras províncias, não estudam os mesmos escritores angolanos”.

Esses escritores, "que eram os escritores amados porque eram filhos da cidade, eram todos subversivos. Não claramente antirregime, mas ainda assim subversivos, mas as obras eram liberadas. Podiam ser lidas em qualquer lugar".

Paula fala de uma outra classe de escritores, que ela chama de "terríveis" (porque era assim que seu último professor de português, de origem metropolitana, os considerava), que só eram "falados a boca pequena". Desses autores proibitivos, ela não lembra de ver ou ouvir falar antes da queda do regime. "Então de um dia para o outro o meu pai apareceu com livrinhos e caderninhos muito usados que obviamente deveriam estar com ele antes, mas eu não sabia. Aí foi o deslumbramento! Com cerca de 14 anos, descobri Luandino Vieira, Arnaldo Santos, Viriato da Cruz..."

Ela conta haver experimentado algo semelhante com a leitura do brasileiro Jorge Amado. "Foi o mesmo tipo de sensação, só que os temas eram próximos de mim". Jorge Amado foi seu primeiro contato com o que chama de "literatura de combate". "Ele não falava só das injustiças sociais, ele propunha soluções. Hoje, retrospectivamente, acho que eram os seus piores livros (O país do carnaval, Cacau, Suor), mas foi importante, para mim, lê-los naquela altura."

Esses autores terríveis só vieram à tona, pelas mãos de seu pai, depois do 25 de Abril, quando já se sabia que haveria independência. Naquele ano da transição, ela fala que deixou de haver coisas proibidas.

Essas coisas proibitivas já apareciam em sua casa de alguma maneira. "Por exemplo, o meu pai ouvia o programa de rádio Angola Combatente, que era emitido fora e ouvido em rádio de ondas curtas. Fazia tanto ruído que era impossível esconder, e assim nós sabíamos que ele ouvia qualquer coisa especial, mas que nós não podíamos ouvir nem falar do assunto. Mas os livros só apareceram nesse período."

Nessa altura Paula já estava em Luanda, faltando dois anos para o vestibular, "que foram atribulados porque mudou muita coisa. O sistema de ensino, os currículos, o ano escolar..." Suas influências de leitura não se atinham mais a sua família, seu pai e irmãs, pois, estando a crescer, buscava novos horizontes. "Eu procurava amigos, já em Luanda, que tivessem a ver com o que eu procurava." 
Ela conta que com a independência, a primeira coisa que se descobriu foram os autores angolanos. "Não só os mais velhos (os terríveis), como outros que iam aparecendo. Publicava-se muito. Depois também se recebia muita coisa de fora, por exemplo publicações da Casa de Las Américas. Mas sobretudo havia muitos livros para comprar. Não havia comida, mas havia livros".

Para Paula, que não se imagina em um mundo sem livros, o momento era de muita euforia.

Sua opção foi estudar temas relacionados a cinema e TV, área em que trabalhou por muito tempo, antes de se dedicar à tradução, seu trabalho atual. Sua vida foi impactada pelos momentos políticos por quais passava o país. "E a minha formação foi nessa área, mas sempre uma formação mais prática do que acadêmica, embora tenha praticado com gente de inestimável valor, professores que vinham a Angola porque Angola era o máximo, e em Angola se estava a fazer a revolução".

Houve de sua parte adesão ao movimento que lutou pela independência. "No início tudo é uma descoberta, um avassalamento, uma coisa inebriante. Para tu veres que eu fazia voluntariado em alfabetização (método Paulo Freire), depois das aulas e eram 10 quilômetros a pé para ir e voltar. Depois, pouco a pouco o cansaço começa a vencer. E dás-te conta que as coisas podiam ser melhores, bem melhores. Acho que aí também entra a diferença entre o tempo coletivo e o tempo individual. Por muito que racionalmente saibas que não se pode fazer tudo num dia, individualmente tu queres mais. Porque tu sabes, mesmo sem pensar nisso, que tens um prazo de validade. E aí também começam as coisas dentro dos partidos, ou das formações que tu apoias e te identificas, a ruir e a mostrar as suas fragilidades, que eram muitas. E percebes que a identificação não é afinal tão grande. Acho que isso começa nos anos 76, 77.”

Sobre sua atuação como alfabetizadora, ela conta que não era necessário uma filiação explícita ao MPLA. "Não era obrigatório, porque não era necessário. Éramos todos, os que ficamos pelo menos, do MPLA. E não era preciso cartão, a gente era e pronto e apresentava-se lá a dizer quero colaborar. Essa era ainda a parte boa, onde confiávamos uns nos outros. Depois começou a embriaguez do poder, a desconfiança, a intolerância, a perseguição, a morte.”

Ela cita o episódio de 27 de maio, em que há uma dissidência no partido liderada por Nito Alves, como marcante nesse processo de desilusão. "Em 77, na altura do golpe de 27 de Maio (continuo utilizando a palavra golpe, mas nem sei se é a terminologia certa, aliás nesse episódio tudo é incerto menos a morte), eu teria 17 anos, tive dois 
amigos perseguidos e mortos, por delito de opinião. Isso marca, eram meus amigos, poderia ter sido eu. E o sonho começa a desmoronar."

Paula acredita que o fato de muitos combatentes que lutaram pela independência terem sido escritores favoreceu o status da literatura no país. "Os escritores na guerrilha e luta de libertação foram importantíssimos, eles deram um outro rumo ao processo. Aliás, se você procurar, vai descobrir que quase todos eles acabaram distanciando-se do partido com o tempo. Terminou a identificação. A Angola de hoje não é a Angola sonhada, apesar de que essa ainda está lá, só precisamos escavar um pouco mais."

Quando a indago sobre como lhe parece que essa literatura ecoou no restante da população angolana, grande parte analfabeta, Paula faz a seguinte reflexão: "É claro que eu só me represento a mim, e pessoas como eu não eram a maioria, mas eram as pessoas que podiam fazer a diferença. A escrita do Luandino não é fácil, mas tu és uma leitora estrangeira. Os analfabetos não poderiam lê-lo, mas podem ouvi-lo. Essa era uma das experiências que se faziam na alfabetização. E as pessoas reconheciam as suas expressões diárias, a linguagem que claro no Luandino está mais que subvertida, mas ainda assim a identificação existia. As pessoas riam na altura certa, por exemplo".

E nos deixa uma dica inestimável: "Faz a experiência de alguém ler o Luandino para ti. Ou poemas do Viriato da Cruz".

Paula recorda ainda que essa efervescência não acontecia na UNITA ou FNLA. "O MPLA era o que parecia mais aberto, mais cosmopolita e por isso atraía os intelectuais. Bastante mais tarde, começas a aparecer alguns cantores na FNLA, e um ou outro escritor na UNITA. Estranho, né? Porque a UNITA também tinha intelectuais, mas acho que não tinha liberdade, dentro do próprio partido, para essas manifestações."

As experiências de menina com a leitura avançaram. E hoje Paula considera-se uma leitora assídua. Ela lê muito escritores contemporâneos de ficção, qualquer nacionalidade, e guarda um lugar aos africanos. “Ando enamorada de uma nova geração de africanos chamados de clássicos do século XXI. Prefiro tudo o que fantasie a realidade, que anda muito crua para o meu gosto. Mas também ensaios, que tenham a ver com questões sociais. Acho que cada vez mais as literaturas não têm fronteiras e os escritores são menos definíveis, e isso agrada-me muito. Ler um romance que pode ser uma abordagem filosófica de um tema, por exemplo. O escritor espanhol Javier Marías faz isso de forma brilhante". Os angolanos surgem quando faço a pergunta diretamente. "Há alguns angolanos sim, uns mais novos outros mais velhos. Ondjáki, Agualusa, Mena Abrantes". 
No mundo de Paula, como ela mesmo diz, pode faltar tudo, menos livros. Esse mundo ela vivenciou na Angola pós-independência, ainda que rapidamente, quando a comida era escassa, mas a literatura, abundante. "O meu ser leitor é anterior ao meu ser. Presumido, né? Mas é verdade, pode faltar tudo, mas livros nunca.”

\section{2 - Cassé}

Carlos Ségio (Cassé) nasceu em Angola em 1960 e alternou seus estudos entre Luanda e Parede, em Portugal, "por ter contraído poliomielite e o sol na Parede ter efeitos medicinais invulgares". Na altura da independência, portanto, contava 15 anos de idade. É filho de intelectual português que, tendo chegado a Angola em 1943, envolveu-se na luta pela liberdade do país e conquistou a nacionalidade angolana sob a égide do novo governo.

Cassé cresceu entre livros e teve nos pais grandes influenciadores. "Meus pais tinham uma biblioteca que, no final da sua vida, entre 1998 e 2000, já ultrapassava os 8000 volumes. Nasci por isso entre livros, música (minha mãe tocava muito bem piano), o estudo obrigatório, o teatro e o cinema."

Suas primeiras memórias de leitura trazem os Irmãos Grimm e os livros de Charles Dickens. "Mas logo aos 14 anos, o livro que mais me marcou - e marca até hoje - foi o Jean-Christophe do Romain Rolland." Os dez volumes de Rolland narram a vida do homem que dá título à série, que teria sido um gênio da música.

O pai de Cassé, advogado, escritor e entusiasta das causas nacionais, forneceu um ambiente propício para o desenvolvimento do gosto pela leitura, que sempre foi para o filho "um prazer absoluto". Essa biblioteca que atraía os olhares do menino era formada também pelo que havia de transgressor naqueles anos. "O pai tinha praticamente tudo o que saía no Brasil e em Portugal, em particular livros proibidos pela censura. Foi assim que aprendi a ler em casa Graciliano Ramos, Guimarães Rosa, Jorge Amado, Rachel Queirós, João Cabral de Mello Neto, Drumond de Andrade, Álvaro Lins, entre outros." Dessa maneira, o que Cassé mais apreciava ler era romance, poesia, biografias e teoria política. 
Com todo esse ambiente a sua disposição, não foi à toa que Cassé se formou jornalista e sociólogo e hoje trabalha como escritor e compositor, tendo publicado livros de poema em Angola, inclusive pela União dos Escritores Angolanos.

$\mathrm{Na}$ escola, cursada em grande parte no período colonial, afirma não ter tido contato com autores angolanos: "Angolanos quase nenhuns. A partir de 72, a Alda Lara, talvez. De resto, autores portugueses: Almeida Garret, Eça de Queirós, Bocage, Luís de Camões, Miguel Torga, Aquilino Ribeiro, Gil Vicente.”

Quando o tema é a literatura chamada clandestina produzida em Angola, Cassé evoca novamente o pai, que tinha acesso a todo o tipo de material, já que ele teria sido “o principal difusor da literatura angolana, brasileira e portuguesa em Angola". No entanto, essa literatura não chegava a ele como interditada, pois "meus pais não me podiam dizer que era proibida até aos 13 anos". Quando acontece o 25 de Abril, Cassé tem 14 anos já e , como rememora, "tornou tudo mais fácil."

O que ele mais se recorda de lhe chegar, no âmbito do proibitivo, era a música. Artistas como os angolanos Bonga e Ruy Mingas, os portugueses José Afonso e Adriano Correia de Oliveira e os brasileiros Chico Buarque e Geraldo Vandré. A poesia declamada também foi uma via privilegiada de contato com o "subterrâneo": "os Jograis de S. Paulo estiveram em Luanda, além da 'chanson' francesa (Ferré, Brassens, Brel belga) Serge Reggiani, Yves Montand, etc., etc.”.

Cassé se lembra de "muitas e boas bibliotecas e livrarias", além de alguns suplementos literários que operavam como uma rede de apoio à leitura ainda no tempo colonial. Ele tece comparações com o momento atual: "Hoje em dia, não há quase nada. Luanda, com 7 milhões de habitantes, tem três livrarias. E as bibliotecas, mesmo as públicas, estão a ser dilapidadas por gente que vai roubando material de arquivo histórico muito importante, quando exerce funções de direção e amedronta os funcionário."

Com a independência, a sociedade angolana experimenta um maior acesso ao livro. E Cassé se recorda das ações de difusão desempenhadas pela UEA. "Até aos anos 90 a União dos Escritores Angolanos desenvolveu um papel extraordinário pela mão de Luandino Vieira. Livros baratos, muita literatura angolana e não só.” No entanto, esse cenário sofre um revés com as mudanças político e econômicas do início dos anos 1990. “A partir da instauração do regime multipartidário e da instauração do eufemismo chamado 'economia de mercado', que no nosso caso resultou num ultra-liberalismo sem limites, a situação hoje é muito pior do que antes da independência." 
A literatura angolana forjada naqueles anos marcou a trajetória de Cassé, que não cita apenas um único escritor que o teria impactado: "Um é impossível... António Jacinto, Ernesto Lara Filho, Aires de Almeida Santos, Alexandre Dáskalos, António Cardoso, Henrique Guerra, Luandino Vieira, Alda Lara, Maurício Gomes, Ermelinda Xavier..."

Quando indagado sobre sua carreira de jornalista e escritor, Cassé evoca como determinantes ter entrado para a rádio como redator e ter começado a escrever crônicas e música. Mas também uma situação peculiar vivida por uma família de intelectuais: "O isolamento a que o pessoal de origem burguesa mas que era marxista e/ou católica progressista como minha mãe, foram submetidos, tendo a percepção desde o início que a maior parte da direção política do país não era nem progressista nem tinha preparação intelectual e política para tal. Hoje vê-se o resultado.” É também por isso que sua poesia e seus escritos, como ele diz, "têm muito de protesto".

Outro aspecto determinante para sua carreira foi a Brigada Jovem de Literatura, que teria sido criada em 1980 por "três ou quatro jovens", Cassé entre eles. Ele conta que esses jovens já haviam abandonado a Juventude do MPLA, descontente que estavam com os rumos políticos do país. "Apoiados pela União dos Escritores (Luandino, Manuel Rui, Pepetela, António Jacinto, meu pai - Eugénio Ferreira) criamos a primeira associação democrática de Angola no pós-independência. Só nos aguentamos dado o fato de sermos filhos de quem éramos. O Buca Boavida por ser filho do então ministro da Justiça, Diógenes Boavida. Eu, por ser filho do Presidente do Tribunal da Relação e jurista muito respeitado, a Irene Neto por ser filha do Agostinho Neto. Mas tivemos sempre a segurança de estado a controlar-nos." Esse movimento, que teria sido iniciado de maneira apartidária, foi extinto "quando a JMPLA nos tomou de assalto e criou uma brigada jovem de literatura de Angola, para destruir a nossa autonomia e as nossas posições pouco simpáticas para com o poder político”.

Mas, em sua opinião, essa relação entre política e literatura também rendeu bons frutos. Para ele, o status que a literatura alcançou no país teve muito a ver com a coincidência entre escritores e combatentes. "Grande parte dos escritores estava no exílio, nas cadeias ou na guerrilha. Outros, vivendo em Angola, entre os quais muitos portugueses progressistas, escreviam, divulgavam e exerciam um papel cívico e intelectual que se tornou fundamental. Este caldo permitiu um sucesso enorme na divulgação da literatura, que foi perdendo espaço logo após a morte do presidente Agostinho Neto", o que ocorreu em 1979. 
Hoje as preferências literárias de Cassé ficam pelo universo lusófono, passando pelos angolanos Henrique Abranches e Pepetela, os portugueses José Saramago, Lobo Antunes e Valter Hugo Mãe e o brasileiro Chico Buarque de Holanda. Em sua trajetória como leitor, Cassé teve ou poderia ter tido acesso a escritores de todo o mundo. Prevalecem na memória e na predileção aqueles que escrevem em sua língua.

\section{$\underline{4.3 \text { - Anabela }}$}

Hoje com 53 anos, Anabela tinha 11 quando Angola tornou-se um país independente. Filha de pai português e mãe negra angolana, ela sempre morou em Luanda, exceto entre os anos de 1983 a 1987, quando ganhou uma bolsa para estudar na então Tchecoslováquia.

Anabela fez todo o seu ensino em escola pública. No período colonial, quando estudou até a quarta classe, ela se recorda não haver ensino obrigatório de literatura. Depois da independência, ela se lembra de livros como Mayombe, de Pepetela, ou Mestre Tamoda, de Uanhenga Xitu. "Não sei precisar se se lia fora ou dentro da escola, mas toda a gente leu". Quando indago como era sua relação com esses livros, ela guarda um silêncio antes de dizer que começou a refletir sobre isso muito mais tarde, porque a essa altura, na escola, ela lia mais em exercícios de interpretação de texto.

Anabela conta que sua mãe - analfabeta, que só sabe escrever o nome - foi uma importante influência. "Provavelmente por isso, incutiu-me a ideia de que para se ser alguém na vida tinha de ler muito (ela dizia que ouvia os brancos a dizer isso). Era preciso estudar muito!" Com irmãos portugueses por parte de pai, Anabela foi, com eles, "obrigada a ler os clássicos da literatura portuguesa", como Eça de Queiroz, Fernando Pessoa e Camilo Castelo Branco. Mas ela não gostava de imposição. "Detesto Saramago" e "nunca consegui ler James Joyce (outra obrigação social). Gosto de escolher o que quero ler."

Até chegar a essas afirmações, a trajetória de leitora de Anabela passou por sucessivas fases, bem delineadas por ela. Os autores de predileção e as formas de obtenção do livro vão se alterando ao sabor de outras mudanças de sua vida e da vida do país. 
"Até aos 11 anos li as sabrinas todas que apareceriam e trocávamos com amigas. Em 1975 grande parte dos portugueses abandonou as casas e o meu padrasto ficou com a casa do patrão e com o que chamaria 'boa biblioteca', alguns livros e revistas."

Em Luanda ela se recorda da Lello - uma livraria "enorme", e também das bibliotecas. "Mas a partir de 1975 a troca entre amigos e prendas era a grande fonte". Além da mãe, algumas amigas também foram determinantes para levar Anabela para perto da literatura. "Noelma Viegas de Abreu, que foi mulher do (escritor) Agualusa, oferecia-me livros".

Em finais dos 70 e início dos 80 "descobrimos os brasileiros, por causa da novela Gabriela", de um Jorge Amado "amadíssimo por essas bandas". O verbo na primeira pessoa do plural é usado por Anabela a partir desta data, num indicativo de que suas descobertas não eram solitárias, mas se filiavam a uma conduta comum no país.

Outra grande referência da juventude foi Simone de Beauvoir, na "fase de rebeldia", completada pelos escritores "sul latinos", a exemplo de Gabriel Garcia Marquez.

Em 1983 ela foi como "bolseira" para Praga estudar medicina ("minha mãe queria uma filha doutora"), voltando em 1987 para Luanda. É nessa fase, no final dos anos 80 e início dos 90, que ela diz ter se interessado pela "literatura anticomunista", citando nomes como Milan Kundera e Anatoli Ribakov, cujo livro Os filhos da Rua Arbat, drama que retrata a repressão stalinista na Rússia dos anos 30, marcou-a muito.

É neste momento também, vivendo em Praga, que ela elabora suas reflexões sobre a literatura angolana com a qual teve contato na escola. Escritores como Pepetela, Manuel Rui ou Uanhenga Xitu, de maneira geral, produziam, de acordo com ela, uma literatura orientadora, educativa. Ela diz que para além dos heróis fictícios que Pepetela criou em seus romances, muitos atribuem a ela a criação de um personagem, vendido como real, que operou como modelo para os pioneiros - as crianças do MPLA: o Ngangula. Usado nas propagandas do partido e em livros escolares, Ngangula teria sido uma criança exemplar, um "miúdo reto, educado, revolucionário", que teria sido assassinado pelas tropas portuguesas quando se dirigia à escola e se recusou a informar onde estavam escondidos companheiros do MPLA. "Todas as crianças da minha idade queriam ser um Ngangula (excelente estudante, bom filho da pátria, revolucionário). Muito mais tarde, nos anos 90, depois de ter estado na Tchecoslováquia, descobri a utilidade dessa literatura. Todos os países de orientação comunista tinham o seu Ngangula". 
Nos anos 90, portanto, Anabela se deparou sobretudo com a descoberta de que o comunismo era um mito, devorando, então, tudo que era anticonunista. Aqui ela usa novamente a palavra "rebeldia", agora para associá-la à ideia de que "o socialismo depois de viver em Praga e através da literatura - não era que pensávamos ser. Vi horrores em Praga".

Seguindo uma linha cronológica, depois veio a descoberta dos clássicos russos. Em finais dos 90, dos clássicos portugueses.

Em 1987 Anabela volta para Luanda sem concluir os estudos em medicina. Em 1988 tem seu primeiro filho, quando deixa de estudar e começa a trabalhar. Depois de 10 anos volta aos estudos, numa inflexão da sua vida determinada pelos livros. "Li $O$ mundo de Sofia, apaixonei-me pela filosofia e fui estudar direito em Luanda, na Universidade Pública”. Hoje Anabela atua como magistrada.

Embora ela tenha vivido uma fase anticomunista na literatura, Anabela não se mostra decepcionada com os rumos de Angola depois da revolução que culminou com a independência. Anabela foi pioneira e depois militante da juventude do MPLA. "Toda a gente era do partido - era o nosso grande orgulho". Ao evocar sua fase de rebeldia e eventual desilusão, a resposta é negativa. "Se não fosse a independência eu não teria chance de ser quem eu sou - disso não tenho dúvidas. Ou seria? Quem sabe. E nós, associamos a independência ao MPLA. Venho de uma família muito pobre e do interior e com ligações à luta armada. A minha mãe aderiu ao partido antes da independência".

Anabela conta sobre a militância dentro do partido, afirmando que era intenso o incentivo à literatura nessas instâncias. "Deu-se início à luta contra alfabetização. Lia-se muito! Ensina-se às pessoas a ler. Acreditávamos na existência de uma sociedade sem 'classes', elites. Sentíamos-nos todos iguais. A literatura era orientada, claro, mas muito intensa".

Ela participou das campanhas de alfabetização como instrutora entre os 14 e 17 anos. "Só por isso a minha mãe aprendeu a ler um pouco e a escrever o nome dela." Nessas ocasiões ela explica que eram trabalhados os textos dos autores locais. E também que os livros eram doados. "Recebia-se muito do Brasil, Portugal e outros países 'socialistas'." Os livros, no começo, eram muito poucos e eram distribuídos. Quando vendidos, tinham preços simbólicos. "Era tudo do Estado".

Sobre a União dos Escritores, Anabela se lembra de ter sido muito importante nos anos 70 no incentivo à escrita, edição e leitura. Acerca do Inald, ela se recorda mais da edição de livros técnicos, como enciclopédias, e também dos discos. 
Quando lhe perguntamos sobre o papel da literatura em sua vida, a resposta vem em forma de exclamação. “O papel da literatura na minha vida?!!! É por ler que estou em Dakar ${ }^{37}$. Este ano li mais um livro do Achille Mbembe, que é coorganizador do atelier pensée - e nesse livro ele aprofunda estudos iniciados pelo Cheikh Anta Diop, que foi muito importante para aceitação de uma racionalidade africana. Vim, justamente, visitar o IFAN - L'Institut Fondamental d'Afrique Noire”.

Anabela finaliza falando da utilidade que a literatura tem para ela, que é a do conhecimento, em múltiplos sentidos. "Desde conhecer pessoas, lugares, cheiros. Há uns anos li O museu da inocência, de Orhan Pamuk, e fui a correr visitar Istambul seria uma grande desgraça ler e não puder ter a oportunidade de trilhar caminhos que percorro pelos livros... Claro que não posso conhecer todos os lugares. Mas vou conhecendo. Devagar. Literatura dá-me a possibilidade de exercitar todos os meus sentidos. Ser o que me apetecer. Há personagens que convivem comigo durante muito ou algum tempo! Ler é viver, intensamente!”

Quanto à outra faceta do conhecimento proporcionado pela literatura, ela diz: "ler, para mim, era o único meio mediante o qual eu exerço influências. Em Angola, tal como no Brasil, vive-se muito 'as aparências'. O nome de família, o poder econômico/financeiro influenciam muito. Mas há outro meio que esbate qualquer um: conhecimento. Só se obtém, lendo.” É com esse veredicto que nossa conversa é encerrada.

\section{4 - Jorge}

O engenheiro civil Jorge passou a primeira infância em Benguela e aos oito anos mudou-se para Luanda, onde viveu até a década de 1980. Hoje com 63 anos, ele viu Angola ser proclamada independente aos 21 anos de idade. Filho de pais portugueses que imigraram ainda crianças para Angola, em 1977 ele cursava o $5^{\circ}$ ano de Engenharia Civil, quando o "forçaram a interromper", de maneira que concluiu posteriormente seus estudos em Portugal, onde hoje mora. Mas sua relação com Angola permanece, "não

\footnotetext{
${ }^{37}$ Em nossa última conversa, quando a pergunta foi feita, via internet, ela estava viajando pelo Senegal.
} 
pode acabar nunca", já que, como ele diz: "minha cultura é mestiça, meu sentir é africano".

Seu interesse como leitor tinha, desde cedo, um endereço certo: a banda desenhada, ou história em quadrinhos. Elas estão entre suas primeiras memórias de leitura. "Na infância e princípio da adolescência, (lia) livros de banda desenhada (quadradinhos) dos heróis da altura: Zorro, Fantasma, Mandrake, e, claro, os da Disney." Na fase de adolescência outros livros vão se juntar a suas preferências, como $A$ aventura dos 5, de Enide Blyton, assim como os clássicos portugueses, entre eles Almeida Garret, Alexandre Herculano, Júlio Dinis, Eça de Queiroz e Camões.

Ainda na adolescência, Jorge recorda-se de clássicos internacionais, como Alexandre Dumas, Emilio Salgari, Máximo Gorki, Dostoievski e Jorge Amado. Como é de se supor, ler era uma prática bastante comum em sua casa e em seus círculos sociais e, para ele, sempre foi identificada com o prazer, e não com a obrigação.

Seus hábitos de leitura foram influenciados por amigos e alguns professores. $\mathrm{Na}$ escola, cursada ainda no período colonial, ele afirma que as indicações de leitura dependiam muito de cada professor ou professora de português. "Tive alguns bons que recomendavam leituras, mas a maior parte não se interessava - estavam de passagem por Angola." No entanto, uma coisa era certa: os clássicos portugueses aos quais já se referiu eram os livros obrigatórios, não havendo qualquer referência a autores angolanos: "Que é isso? Éramos todos portuguesinhos de gema”, ele ironiza. "Dos brasileiros idem, de vez em quando lá 'escapava' o Jorge Amado, mas nunca os subterrâneos.”

No tempo colonial, o acesso aos livros se dava sobretudo por empréstimo à biblioteca do liceu e da Câmara Municipal de Luanda. As compras, como ele afirma, eram raras, por questões financeiras. Os livros também lhe chegavam pelos amigos de seus pais, que ofereciam enciclopédias e livros sobre a natureza.

Em meio a essas possibilidades seu gosto por um certo tipo de literatura foi se formando. Suas preferências ficavam pelos romances históricos, os dramas e a "poesia engajada" de autores como o cabo-verdiano Daniel Filipe e o chileno Pablo Neruda, além da "poesia das canções de luta". "E sempre a boa banda desenhada - Corto Maltese, era o máximo!”. Personagem de quadrinhos criado pelo italiano Hugo Pratt, Corto Maltese era um marinheiro britânico que, em suas aventuras, muitas vezes cruzava com personagens reais. Sobre os autores angolanos, "na minha juventude, 
gostei muito de ler Arnaldo Santos. Mais tarde, encontrei-me com o Boaventura Cardoso".

Quando abordo o tema da literatura clandestina produzida em Angola nesse período, Jorge é taxativo: “não concordo com o 'muito se produziu' se nos referirmos a autores angolanos nacionalistas. O que circulava de maneira subterrânea eram os livros e romances políticos de autores portugueses e principalmente estrangeiros. De resto apenas tomei conhecimento de opúsculos e panfletos de movimentos nacionalistas angolanos, de maneira muito esporádica."

Jorge percebe uma mudança no que tange à rede de apoio à leitura nos momentos anteriores e posteriores à Revolução de Abril de 1974. No período colonial, ele se recorda que os jornais tinham suplementos literários, a maior parte com periodicidade mensal, mas eram centrados na produção portuguesa e ocidental. Depois da independência, ele julga que "quanto à logística, pouco melhorou; as bibliotecas que existiam pouco trabalho faziam". No entanto, acredita que houve, sim, "um incremento com a criação de estrutura governamental de apoio ao livro", do qual o Inald seria um bom exemplo. De acordo com ele, o Instituto começou a publicar os autores angolanos, e a distribuir os livros gratuitamente ou a preços módicos. "Havia muita sede de conhecimento, em qualquer feirinha do livro os livros (poucos, infelizmente) rapidamente desapareciam, mas não posso afirmar que houve uma democratização da leitura: afinal $80 \%$ da população era analfabeta ou profundamente iletrada." Apesar de reconhecer que houve esforços no sentido a alfabetização, afirma que essa "onda" continuou até 1977 quando, devido aos acontecimentos de maio, "tudo acabou, e nesse aspecto Angola mergulhou na obscuridade; principalmente a área cultural sofreu bastante".

A essa altura, Jorge já havia concluído seus estudos no liceu, estando na universidade, mas pelo conhecimento que tinha acerca do ensino e educação em Angola, "tentou-se nos primeiros anos alterar o paradigma do ensino da literatura nas escolas, mas o poder instituído pouco fez". O que ele observa é que "para haver leitores tem de haver um bom domínio da língua, e o estudo do português nas escolas foi cada vez mais se degradando. Aliás, aos poderes autocráticos sempre interessou que as massas não fossem cultas e dotadas de conhecimento".

Seu posicionamento sobre a afirmação de que a relação entre guerrilheiros e escritores teria favorecido um certo status da literatura em Angola chama a atenção. Ele considera "absurda" essa associação. "Tirando o Pepetela e António Jacinto, quem são 
esses escritores que combateram? O próprio Agostinho Neto escreveu um livro de poemas, mas combateu aonde? Houve uma euforia sim, as pessoas tinham sede de saber, como atrás referi, mas o poder quando reparou que o conhecimento conduzia à libertação das mentes, tratou logo de cortar rente qualquer desenvolvimento. Faço notar que estou a falar do caso geral, pois apareceram casos esporádicos de sucesso de jovens escritores." Por esses autores angolanos, ou por suas atividades, ele se interessou mais profundamente após o 25 de Abril. Antes desse episódio ele teria lido poemas de António Jacinto e Luuanda, de Luandino. O restante de sua obra, assim como livros do Pepetela, apenas depois da Revolução dos Cravos.

Jorge ressalta que, a respeito da formação de um público leitor, isso se deu em partes, "apenas nas elites urbanas, negras e principalmente mestiças”.

A literatura e o livro cumprem um papel importante na vida de Jorge: "a minha comunicação com o outro melhora sempre que acompanho a vida cotidiana com a leitura de livro". Ele faz questão de dizer que esse livro deve ser em papel, "pois faz-me falta o seu toque e folhear". Suas preferências literárias de hoje são "as mesmas de sempre", a exemplo do romance histórico e da poesia, esta agora em maior quantidade "julgo-me um bom dizedor de poesia". A boa banda desenhada segue na dianteira de suas predileções, abrindo e encerrando a nossa interlocução.

\section{5 - Lendo leitores}

Fazer uma leitura das trajetórias desses leitores nos parece quase dispensável, tamanha a consistência dos relatos. As histórias são autoexplicativas, contadas por narradores que as conduziram por mãos firmes e que são deveras conscientes de seu papel na trama que foi a Angola que vivenciaram e a literatura que dela emanou. Avançar na análise, no entanto, é reconhecer que tínhamos propósitos específicos nesse diálogo e que buscávamos respostas que iluminassem nossas hipóteses. Optamos, assim, por apontar aspectos que nos parecem relevantes, na medida em que ou são singulares, ou recorrentes entre as quatro histórias, e que entram em debate com o projeto literário então em curso em Angola, descrito no capítulo anterior. A análise foi feita a partir do agrupamento por eixos temáticos, que facilitam a comparação entre aspectos convergentes ou divergentes de nossos entrevistados, que partilharam o mesmo contexto social. Ressaltamos ainda que, se em nossas conversas havia algumas perguntas que não 
deixamos de fazer a todos os interlocutores, as categorias de análise foram construídas a posteriori, a partir dos dados coletados. Lembramos ainda, com a citação abaixo da pesquisadora Maria Helena Menna Barreto Abrahão, que trabalha com metodologias que envolvem registros autobiográficos, que, mais que dados objetivos, nos interessa o que as memórias desses interlocutores retiveram como real para cada um:

Ao trabalhar com metodologia e fontes dessa natureza o pesquisador conscientemente adota uma tradição em pesquisa que reconhece ser a realidade social multifacetária, socialmente construída por seres humanos que vivenciam a experiência de modo holístico e integrado, em que as pessoas estão em constante processo de auto-conhecimento. Por esta razão, sabese, desde o início, trabalhando antes com emoções e intuições do que com dados exatos e acabados; com subjetividades, portanto, antes do que com o objetivo (ABRAHÃO, 2003, p. 80)

Antes de adentrarmos nas análises, cabe relembrar os perfis de cada entrevistado para melhor compreendermos o lugar de onde falam, tendo em vista as diferenças que, em uma sociedade como a angolana, marcam suas experiências: Paula é negra, descendente de geração de angolanos, sendo oriunda de uma família de funcionários públicos, o que, na época, consistia em pertencer a uma certa elite. Viveu a infância em Benguela e o início da vida adulta em Luanda, tendo 15 anos na altura da independência. Cassé é filho de português e de uma angolana mestiça, sendo seu pai um reconhecido intelectual, que militou pelas causas angolanas. $\mathrm{Na}$ infância passou algumas temporadas em Portugal, mas morava em Luanda e, quando da independência, tinha 15 anos. Anabela é filha de pai português e de mãe negra angolana, analfabeta. Sempre morou em Luanda, exceto por cinco anos no início da vida adulta, quando foi como bolsista para a Tchecoslováquia. Ela tinha 11 quando Angola tornou-se um país independente. Já Jorge morou em Benguela até os oito anos e depois mudou-se para Luanda, onde viveu até a década de 80. É branco, embora se sinta, como disse, mestiço. Filho de pais portugueses que imigraram para Angola ainda pequenos, tinha 21 anos em 1975. 


\subsection{1 - Leitor em formação: bibliotecas familiares, leituras obrigatórias e paisagem literária}

Um traço compartilhado que nos parece mais marcante nos quatro relatos está relacionado aos primeiros passos desses leitores: Paula, Cassé, Anabela e Jorge se beneficiaram da tradição de leitura de suas famílias e, os três primeiros, de suas vastas bibliotecas. Foi primeiramente em casa que a leitura se apresentou a eles, muito jovens ainda, mesmo crianças. Pais, mães e irmãos estão entre as primeiras grandes influências, todos gravitando em torno dessas bibliotecas, que foram construídas de maneiras distintas.

Se a coleção dos pais de Cassé era das maiores de Angola, contendo milhares de títulos e um repertório eclético, condizente com um advogado e reconhecido intelectual, a que Anabela teve acesso foi aquela herdada por seu padrasto, que ficou com a casa do patrão português que saiu do país com a independência. Essas bibliotecas foram determinantes para as primeiras leituras dos nossos interlocutores, que se apropriavam daquilo que tinham a sua mão. Cassé conta que seu pai "tinha praticamente tudo o que saía no Brasil e em Portugal, em particular livros proibidos pela censura”. E diz que foi assim que aprendeu a ler "em casa" nomes como Graciliano Ramos, Guimarães Rosa, Jorge Amado, João Cabral de Mello Neto, entre outros brasileiros. Anabela, em cuja biblioteca figuravam "alguns livros e revistas", afirma ter lido, até os 11 anos, as "sabrinas todas que apareceriam". Coleções como Sabrina, Bianca e Julia, romances de enredo simples voltados para o público feminino que, no Brasil, foram tradicionalmente vendidos em banca, estão distantes dos livros citados por Cassé, mas foram eles que despertaram o interesse de Anabela pelo mundo da leitura.

Também foi na biblioteca de casa, a qual tinha livre acesso, que a Paula leitora começou a se formar. As primeiras leituras evocadas por ela são livros infantis de autores estrangeiros, reafirmando a ausência de autores angolanos para este público no tempo colonial. Paula lia textos da "era dos patinhas e mickeys", assim como as coleções dos 5 e dos 7 de Enid Blyton, autora britânica. As memórias das primeiras leituras de Jorge coincidem com a de Paula. Interessante notar que ambos leram a coleção de Enid Blyton e que tinham o hábito de tomar livros às Câmaras Municipais, um em Luanda, outra em Benguela, que provavelmente partilhavam de um acervo em grande parte comum. As memórias iniciais de Cassé trazem os Irmãos Grimm e os 
livros de Charles Dickens, reiterando a presença de autores europeus nessas bibliotecas particulares.

As cidades aqui evocadas, Luanda e Benguela, não são caracterizadas como avessas ao mundo letrado: livrarias - algumas "enormes" como a Lello, de acordo com a memória de Anabela -, bibliotecas do liceu e das Câmaras Municipais são as instituições que aparecem como fontes de livros, que também era objeto de troca e de presentes: a Jorge muitos chegaram pelas mãos dos amigos de seus pais. Embora seja possível, por critérios atuais, mensurar o que seria uma boa rede de livrarias e bibliotecas em uma cidade, o que interessa destacar dessas memórias é que os entrevistados guardam um cenário de certa forma propício para a leitura. Em nenhum momento, em suas falas, aparece a escassez ou a ausência associada ao mundo da literatura em Angola. Cassé, inclusive, se recorda de haver "muitas e boas bibliotecas e livrarias em Luanda", situação que julga melhor que nos tempos atuais: "Hoje em dia, não há quase nada. Luanda, com 7 milhões de habitantes, tem três livrarias".

Anabela conta que sua mãe, que era analfabeta, foi uma importante influência. "Provavelmente por isso, incutiu-me a ideia de que para se ser alguém na vida tinha de ler muito (ela dizia que ouvia os brancos a dizer isso). Era preciso estudar muito!"’. Em uma sociedade de tradição oral e intensamente estratificada, o universo letrado, que pertencia ao território do colonizador, era valorizado e almejado. Para Paula, as principais referências eram as irmãs mais velhas: "tudo o que elas liam eu acabava lendo também porque estava ali ao lado". Essas influências, mais afetivas, vão contrastar com as leituras impostas pelas escolas.

Os entrevistados, que tinham entre 11 e 21 anos quando Angola tornou-se um país independente, realizaram parte de seus estudos no tempo colonial. Deste período guardam na memória, no que tange à literatura, um ensino português que julgam rigoroso. Vale lembrar, como vimos, que a escola, não era lugar para todos, de maneira que nossos interlocutores, podemos afirmar, pertenciam a uma pequena elite, que incorporava brancos, além de uma pequena parcela de negros e mestiços. Todos evocam os clássicos portugueses como leituras obrigatórias, entre eles Camões, Almeida Garret e Eça de Queiroz. Paula sugere que esse ensino primário exigente seria um dos motivos para que o português tivesse se disseminado: "Para ver que Angola era, e é, o único país onde as pessoas não se entendem todas a não ser em português. Desde muito cedo, e refiro-me aos primeiros anos da primária, aprendíamos os clássicos”. Anabela, que era a 
mais jovem e no período não tinha literatura na escola, teve contato com esses mesmos autores pelas mãos dos irmãos portugueses que possuía por parte de pai.

Os autores angolanos não eram referência na escola. Mas é interessante notar, nos registros de Paula, como alguns poetas locais apareciam, entre eles Alda Lara, Aires de Almeida Santos e Ernesto Lara Filho: “Creio, e estou pensando nisto agora, que deveria haver uma certa liberdade de escolha por parte dos professores, porque amigos meus da mesma idade, mas de outras províncias, não estudam os mesmos escritores angolanos". Ser filho de Benguela, para alguns professores, garantia que alguns autores, ainda que antirregime, pudessem ser estudados. Essa memória é compartilhada por Cassé, que também nota a ausência de angolanos no currículo, exceto, "talvez", por Alda Lara. Os portugueses figuravam com todo o seu cânone. Jorge caminha pela mesma senda, dando como certo os clássicos portugueses e nenhum autor angolano. Ele ironiza: "Que é isso? Éramos todos portuguesinhos de gema".

Notamos que os entrevistados fazem distinção entre os livros acessados nessas bibliotecas particulares e a leitura imposta pela escola: suas lembranças mais sentimentais estão ligadas ao primeiro caso, uma leitura forjada no ambiente familiar e em meio à liberdade. As leituras obrigatórias não foram esquecidas, mas o lugar destinado a elas é o da opacidade do dever. "Gosto de escolher o que quero ler", reitera Anabela. São muitos os estudos voltados para a formação do leitor que apostam em um ambiente de liberdade para que a prática da leitura seja incorporada. Marisa Lajolo, por exemplo, afirma que, no âmbito escolar, "a leitura só se torna livre quando respeita, pelo menos em momentos iniciais de aprendizado, o prazer e a aversão de cada leitor em relação a cada livro" (LAJOLO, 1993, p. 108).

Outra informação que merece comentário neste tópico é o fato de Angola, um país na África com alto índice de analfabetos, compartilhar livros e autores, pelos olhos desses leitores, de grande circulação em outros países do mundo ocidental: das sagas britânicas aos quadrinhos norte-americanos como Zorro, Fantasma, Mandrake e aqueles da Disney, rememorados por Jorge; das coleções voltadas para o público feminino aos brasileiros elencados por Cassé, a sensação que temos ao dialogar com nossos entrevistado é que pertencemos a uma mesma comunidade de leitores e que Angola não deixou de conhecer o que de popular se produziu em outros continentes, ainda que a difusão tenha sido em ambientes restritos. 


\subsection{2 - O 25 de Abril e o novo cenário para os livros}

Mais do que a independência, o 25 de $\mathrm{Abril}^{38}$ é o momento histórico que teria dado início, para esses leitores, às transformações no cenário angolano no que tange ao acesso a livros e a uma nova produção literária. Certamente o governo que assumiu o país com a independência foi responsável por uma série de implementações, reconhecem nossos entrevistados, mas na memória de Paula, Cassé e Jorge, que evocaram espontaneamente a data, o marco não seria a independência, mas a Revolução dos Cravos. É a partir daí que eles reconhecem o fim da censura, o que fez com que a produção cultural de caráter subversivo, tanto a literatura como a música, deixasse de ser proibida.

Cassé afirma que quando acontece o 25 de Abril, “tornou tudo mais fácil.” Para ele, mais que a literatura, era a música que lhe chegava como interdita, pelos nomes de angolanos como Bonga e Ruy Mingas, e também de portugueses e brasileiros identificados com as causas nacionais. Paula lembra que foi depois do 25 de Abril que ela ouviu falar dos escritores "terríveis", porque subversivos e proibitivos. "Então de um dia para o outro o meu pai apareceu com livrinhos e caderninhos muito usados que obviamente deveriam estar com ele antes, mas eu não sabia”. Foi a partir daí, quando já se sabia que haveria independência, de acordo com ela, que deixou de haver coisas proibidas. Para Cassé e Paula, o 25 de Abril, portanto, seria sinônimo de uma certa liberdade, a primeira insurgência do projeto que viria com a nova nação. Todos os entrevistados reconhecem, no entanto, que para além do 25, a independência trouxe mudanças impactantes para o cenário literário.

Paula conta que neste momento, a primeira coisa que se descobriu foram os autores angolanos. A sua sensação é que se publicava muito, além de se receber muita coisa de fora. "Mas sobretudo havia muitos livros para comprar. Não havia comida, mas havia livros". É marcante sua sensação de que neste período de tanta escassez, os livros abundavam. A ideia é corroborada por Cassé, que explicita as ações de difusão do livro levadas a cabo pela UEA. "Até aos anos 90 a União dos Escritores Angolanos desenvolveu um papel extraordinário pela mão de Luandino Vieira. Livros baratos, muita literatura angolana e não só.” Cassé afirma que este cenário passou por mudanças

\footnotetext{
${ }^{38}$ A Revolução de 25 de Abril de 1974, conhecida como Revolução dos Cravos, pôs fim ao Estado Novo português. Liderada pelo Movimento das Forças Armadas, composto em grande parte por capitães que tinham participado das guerras coloniais, tinha como um dos objetivos centrais o fim da ingerência portuguesa nos territórios de África.
} 
justamente no período que abrange este trabalho, no início dos anos 90: "A partir da instauração do regime multipartidário e da instauração do eufemismo chamado 'economia de mercado' que no nosso caso resultou num ultra-liberalismo sem limites, a situação hoje é muito pior do que antes da independência."

Jorge tem uma visão mais reticente: ele diz, primeiramente, que depois do $25 \mathrm{de}$ abril, "quanto à logística, pouco melhorou; as bibliotecas que existiam pouco trabalho faziam". Na sequência ele reconhece um incremento na produção literária, com a criação de uma estrutura governamental de apoio ao livro, assim como haver no período muita sede de conhecimento: "em qualquer feirinha do livro, os livros (poucos, infelizmente) rapidamente desapareciam". O Inald seria um bom exemplo dessa estrutura que, segundo ele, teria publicado autores angolanos e distribuído livros gratuitamente ou a preços módicos. No entanto, ele prefere não falar em democratização da leitura, já que, de acordo com ele, $80 \%$ da população era analfabeta ou profundamente iletrada. Para Jorge, o governo não tinha interesse numa real popularização da leitura: além de afirmar que o estudo do português nas escolas foi se deteriorando, ele defende que "aos poderes autocráticos sempre interessou que as massas não fossem cultas e dotadas de conhecimento". O que, para ele, teria sido um pequeno impulso, logo minguou: "o poder, quando reparou que o conhecimento conduzia à libertação das mentes, tratou logo de cortar rente qualquer desenvolvimento".

Anabela, que foi pioneira e militou na Juventude do MPLA, informa que foi neste período que se iniciou a luta contra o analfabetismo. "Lia-se muito! Ensina-se às pessoas a ler... Acreditávamos na existência de uma sociedade sem 'classes', elites. Sentíamos-nos todos iguais. A literatura era orientada, claro, mais muito intensa”. Ela recorda que no começo os livros eram poucos, mas eram distribuídos ou, quando vendidos, tinham preços simbólicos. "Era tudo do Estado". Sobre a União dos Escritores, Anabela se lembra de ter sido muito importante nos anos 70, sobretudo no incentivo à escrita, edição e leitura. Quanto ao Inald, teria ficado com a edição de livros técnicos e enciclopédias, além da produção dos discos.

Mais jovem entre os entrevistados, Anabela também se recorda de como essas mudanças impactaram o ensino. Sobre livros como Mayombe, de Pepetela, ou Mestre Tamoda, de Uanhenga Xitu, ela diz: "Não sei precisar se se lia fora ou dentro da escola, mas toda a gente leu". Posteriormente ela elabora uma visão crítica sobre essa literatura com a qual ostensivamente teve contato na adolescência: esta teria sido uma literatura 
orientadora, educativa. Conta ainda da propaganda que o governo fazia em torno de um personagem, o Ngangula, que figurava nos livros escolares. "Todas as crianças da minha idade queriam ser um Ngangula (excelente estudante, bom filho da pátria, revolucionário). Muito mais tarde, nos anos 90, depois de ter estado na Tchecoslováquia, descobri a utilidade dessa literatura. Todos os países de orientação comunista tinham o seu Ngangula”.

Dois aspectos saltam aos olhos nessas falas relativas ao período de transformações iniciado com o 25 de Abril e consolidado com a independência: de um lado, uma maior circulação de livros de autores angolanos e o papel do Estado nesta ação, também por intermédio da União e do Inald; de outro, uma vontade de conhecimento, acessível por meio dos livros, que emanava da população. Os livros, em grande quantidade para Paula e Cassé, ainda insuficientes para Jorge e Anabela, eram, para todos eles, acessíveis, tanto pelo preço módico quanto pelo fato de serem gratuitamente distribuídos. Esse momento de liberdade parece ter contagiado a população, que consumia rapidamente os livros.

Ainda sobre o papel do Estado, Jorge traz uma visão singular em relação aos demais: o governo teria estancado esse processo de incentivo à leitura quando percebeu que a população, nutrida de conhecimento, poderia se libertar e produzir reflexões que não interessariam ao próprio Estado.

\subsection{3 - Histórias de arrebatamentos: inflexões nas trajetórias dos leitores e o significado da leitura}

São múltiplas as transformações provocadas pela leitura, argumenta Michèle Petit. "A leitura pode contribuir em todos os aspectos que mencionei: acesso ao conhecimento, apropriação da língua, construção de si mesmo, extensão do horizonte de referência, desenvolvimento de novas formas de sociabilidade...” (PETIT, 2008, p. 101). Nas falas de nossos interlocutores, percebemos essas e outras articulações em operação.

Antes de tudo a leitura, sobretudo de obras literárias, é fonte de prazer para esses leitores. É, ainda, uma experiência essencial em suas vidas: faz parte do seu cotidiano, é algo com que estiveram sempre em contato. É perceptível como foi prazeroso para eles falar de suas leituras, assunto que manejam com desenvoltura. Existe já, entre esses entrevistados, uma reflexão sedimentada sobre o papel da literatura em suas trajetórias. 
No entanto, se todos parecem se apropriar com paixão dos livros, é possível perceber como, em cada um, a literatura tem uma serventia prioritária e como algumas trajetórias foram, mais que outras, profundamente marcadas pelos livros ou pela experiência literária.

O termo que Paula utiliza para descrever seu encontro com autores como Luandino Vieira, Arnaldo Santos e Viriato da Cruz foi "deslumbramento". Se ela já havia tido contato com o que chama de literatura de combate com o brasileiro Jorge Amado, esses autores lhe traziam temas próximos, do seu cotidiano, fazendo com que experimentasse uma sensação nova, antes impensada. Essa literatura parece ter contagiado as escolhas de Paula. Embora ela não relacione diretamente os fatos, em seu discurso essa euforia em torno da literatura recém descoberta vem encadeada a sua adesão ao MPLA e ao seu trabalho como alfabetizadora nas campanhas do governo. Ela diz: "no início tudo é uma descoberta, um avassalamento, uma coisa inebriante. Para tu veres que eu fazia voluntariado em alfabetização, depois das aulas e eram 10 quilômetros a pé para ir e voltar". Paula, cujos livros lhe fizeram companhia desde muito menina, atribui a eles um papel central em sua vida: "O meu ser leitor é anterior ao meu ser", ela afirma, de maneira elaborada. Ela diz ainda que a ela pode faltar tudo, mas nunca os livros. Isso está, portanto, em primeiro plano em sua vida.

Cassé também parece ter sido arrebatado pelos livros: o menino que tinha à sua disposição milhares de volumes na biblioteca de seus pais, tornou-se jornalista, escritor e compositor, sempre militando em torno da palavra. Jorge, que se formou engenheiro, vê uma utilidade muito prática a suas leituras: "a minha comunicação com o outro melhora sempre que acompanho a vida cotidiana com a leitura de livro". Apesar de estar relacionada ao prazer e à fruição, ele também extrai da leitura o que Petit chama de acesso ao conhecimento e o desenvolvimento de novas formas de sociabilidade.

De todas as trajetórias, a de Anabela talvez seja a que mais foi impactada pelos livros. Ao menos a sua narrativa está toda entrelaçada a eles, lendo o mundo a partir dos livros ou se permitindo tomar decisões fundamentada neles. "Ao final de uma leitura, o mundo apresentado pelo livro continua tendo uma vida autônoma dentro de nós. Nos vemos forçados a criar novas histórias a partir desse mundo", afirma o antilhano Patrick Chamoiseau (1997, p. 36), oferecendo uma compreensão para essa dinâmica.

De maneira como ela elaborou suas histórias, os livros dão sustentação a distintas fases de sua vida. É o caso da juventude, a fase da "rebeldia", apoiada por exemplo por autoras como Simone de Beauvoir. É como se os livros operassem de duas 
maneiras: ampliando seu olhar para o que queria ser e também autorizando a ser quem pretendia. É ainda a literatura que lhe permite compreender melhor o seu mundo angolano que, nos anos 80, tinha ficado para trás: em Praga, onde foi estudar medicina, ela teve contato com autores como Milan Kundera e Anatoli Ribakov, que ela classifica como "literatura anticomunista". É somente aí que ela consegue refletir sobre aquela literatura angolana com a qual teve contato na escola e que depois julga como orientada, de maneira a cumprir um propósito de Estado. "O socialismo - depois de viver em Praga e através da literatura - não era que pensávamos ser. Vi horrores em Praga", afirma Anabela. Ela experimentou essa sensação de duas maneiras diferentes: em seu dia a dia e no imaginário de seus livros, esses, talvez, apresentando a realidade de maneira mais contundente.

Em outra inflexão na sua trajetória provocada pelos livros, Anabela, que não terminou o curso de medicina e voltou para Luanda, ficando 10 anos sem se dedicar os estudos, se encontra com $O$ mundo de Sofia, do norueguês Jostein Gaarder: "Apaixoneime pela filosofia e fui estudar direito em Luanda", conta Anabela, que hoje tem a profissão que, de certa forma, lhe foi oferecida pelos livros. Ao terminarmos uma leitura, afinal, esse livro segue sobrevivendo, nos impulsionando a criar novas histórias, nos alerta Chamoiseau.

Para Anabela, que teve a influência da mãe analfabeta, para quem era preciso ler muito "para ser alguém na vida", a literatura opera na chave do conhecimento, mas também do sonho: os livros funcionam como um primeiro caminho, que despertam o desejo que posteriormente ela busca materializar. É o caso das relações que estabelece entre suas leituras e suas viagens: "Desde conhecer pessoas, lugares, cheiros. Há uns anos li O museu da inocência, de Orhan Pamuk, e fui a correr visitar Istambul”. Na chave do conhecimento mais pragmático, ela finaliza "ler, para mim, era o único meio mediante o qual eu exerço influências. Em Angola, tal como no Brasil, vive-se muito 'as aparências'. O nome de família, o poder econômico/financeiro influenciam muito. Mas há outro meio que esbate qualquer um: conhecimento. Só se obtém, lendo.”

O que destacamos desse tópico é que, ao ouvirmos os leitores angolanos de literatura, não salta aos olhos alguma especificidade no que tange ao papel da literatura em suas vidas. Poderiam ser leitores de qualquer parte do mundo que se permitiram levar pelo que a literatura pode oferecer a qualquer um que se aventure por suas páginas: o prazer estético, o sonho, o conhecimento, o impulso para a ação. Essas características talvez sejam o que a literatura tem de imanente. 


\subsection{4 - O político e o literário: leituras transversas}

A história literária de Angola, já vimos, caminha ao lado de um projeto político que busca primeiro a autonomia e depois a reconstrução da nação. Nas entrevistas feitas, os fatos políticos vão aparecendo nas falas dos leitores ao longo das narrativas, por vezes associados, por vezes distantes da experiência literária. Em uma derradeira leitura, no entanto, vemos como estão imbricados.

Aqui é preciso expor que, apesar das conversas terem seguido um certo ritmo ditado pelo entrevistado, uma pergunta específica foi feita a todos, da mesma forma: Estudiosos afirmam que o fato de em Angola muitas vezes se confundirem os guerrilheiros e os escritores favoreceu o status da literatura no país e houve no pósindependência uma euforia em torno do livro em Angola. O que acha dessa afirmação? A resposta a essa pergunta ensejou essa reflexão mais direcionada entre política e literatura.

A afirmação de Jorge é singular. Ele julga "absurda" essa associação. "Tirando o Pepetela e António Jacinto, quem são esses escritores que combateram? O próprio Agostinho Neto escreveu um livro de poemas, mas combateu aonde?" Jorge desfaz essa associação, tão frequente entre os estudiosos da literatura angolana, afirmando que os casos foram poucos e insuficientes para suscitar o referido prestígio. No entanto, independentemente de estarem vinculados, guerrilheiros e escritores, ele reconhece o surgimento de bons autores angolanos nesse período.

Jorge, que, como vimos, já ofereceu críticas ao governo nos programas de incentivo à leitura, que teria sido momentâneo, identifica algumas ações positivas, como a alfabetização da população. No entanto, para ele houve uma data limite para elas: o 27 de Maio ${ }^{39}$. Ele usa a palavra "onda" para denominar esse movimento que teria persistido até 1977, quando "tudo acabou, e nesse aspecto Angola mergulhou na obscuridade; principalmente a área cultural sofreu bastante".

O 27 de Maio também foi marcante na visão que Paula, otimista quando da independência, tinha acerca do processo. Suas afirmações são contundentes. "Em 77, na altura do golpe de 27 de Maio (continuo utilizando a palavra golpe, mas nem sei se é a terminologia certa, aliás nesse episódio tudo é incerto menos a morte), eu teria 17 anos,

\footnotetext{
${ }^{39}$ Uma dissidência no seio do MPLA liderada por Nito Alves articulou um golpe contra o governo em vigor, de Agostinho Neto, a 27 de maio de 1977. O movimento foi denominado de fraccionismo. A resposta do governo foi sangrenta e resultou em milhares de mortos, muitos deles sem qualquer ligação com o ocorrido.
} 
tive dois amigos perseguidos e mortos, por delito de opinião. Isso marca, eram meus amigos, poderia ter sido eu. E o sonho começa a desmoronar.” Ao falar de sua atuação como alfabetizadora, ela rememora o que havia de bom no período, quando “confiávamos uns nos outros. Depois começou a embriaguez do poder, a desconfiança, a intolerância, a perseguição, a morte". Em resposta a nossa pergunta, Paula defende que o fato de muitos combatentes terem também assumido o papel de escritores contribuiu para o status que a literatura alcançou no país, pois eles teriam dado um novo rumo ao processo. "Aliás, se você procurar, vai descobrir que quase todos eles acabaram distanciando-se do partido com o tempo. Terminou a identificação. A Angola de hoje não é a Angola sonhada, apesar de que essa ainda está lá, só precisamos escavar um pouco mais". À sua desilusão ela soma a que outros angolanos, inclusive os escritores e membros do alto escalão do partido, teriam sofrido. Seu desencanto é político, não literário: ela faz questão de salvar essas personalidades, sugerindo seu distanciamento do governo.

Cassé enxerga nos autores uma atuação política na divulgação do que se passava no país, o que, para ele, foi fundamental. Mais que escritores, eles exerceram um papel "cívico e intelectual", que teria favorecido a literatura. "Este caldo permitiu um sucesso enorme na divulgação da literatura, que foi perdendo espaço logo após a morte do presidente Agostinho Neto". Para Cassé, o ano mais marcante teria sido, portanto, o de 1979. A morte do presidente aparece como este momento de inflexão, sendo que o 27 de maio não emerge espontaneamente em seus registros.

Em sua trajetória, um episódio marcante que envolve política e literatura foi a participação na Brigada Jovem de Literatura, que teria sido criada em 1980 como espaço para a o estímulo da criação artística. Cassé afirma ter sido um dos articuladores do movimento, em princípio apartidário, que posteriormente teria sido apropriado pela Juventude do MPLA. A Brigada teria nascido a partir de uma insatisfação pelas mãos de jovens descontentes com os rumos políticos do país. Apoiados pela União dos Escritores, Cassé conta que a existência da iniciativa só foi possível "dado o fato de sermos filhos de quem éramos". Isso porque o Estado exercia uma vigilância constante, deslegitimando as tentativas democráticas de organização. O movimento, neste formato, teria sido extinto "quando a JMPLA nos tomou de assalto e criou uma brigada jovem de literatura de Angola, para destruir a nossa autonomia e as nossas posições pouco simpáticas para com o poder político". Notamos nessa fala de Cassé como a literatura surge em resposta a um problema político: os jovens, descontentes com os rumos que o 
MPLA impunha à nação, articulam-se em torno de um movimento criativo, não político em sua essência.

Anabela assume uma postura contrária a de Paula, que se decepcionou com a política, mas não com a literatura. Anabela vivenciou uma fase anticomunista na literatura, forjada em Praga, e revelou um certo desencanto ao reconhecer que esteve, em seu país, submetida a uma literatura que tinha uma finalidade educativa clara. No entanto, a decepção não é marcante em seu discurso sobre o que aconteceu ao país após a independência, ao menos nos primeiros anos: "Se não fosse a independência eu não teria chance de ser quem eu sou - disso não tenho dúvidas. Ou seria? Quem sabe. E nós, associamos a independência ao MPLA. Venho de uma família muito pobre e do interior e com ligações à luta armada. A minha mãe aderiu ao partido antes da independência".

São múltiplas as intersecções entre política e literatura em Angola. Esses leitores, entretanto, fazem distinções relevantes, salvaguardando os escritores angolanos e sua produção em suas avaliações. Embora reconheçam as conexões existentes, ou isentam a parcela de autores dos fatos políticos que provocaram decepção ou seguem reconhecendo a importância de sua obra literária.

\subsection{5 - O livro angolano e o leitor angolano}

As relações entre os leitores cujos depoimentos foram escolhidos e os autores angolanos foram construídas em meio a muitas outras referências de leitura. Formados entre um ambiente privado que favoreceu o contato com os clássicos ocidentais e uma escola que privilegiou os autores portugueses, esses leitores foram se apropriando aos poucos do livro angolano, sem revelar por eles grande predileção.

Os escritores angolanos surgem espontaneamente e com maior vigor apenas na voz de Paula, que foi arrebatada por autores que, a exemplo de Luandino Vieira e Viriato da Cruz, lhe atraíram pela ruptura formal, pela abordagem dos temas da terra e pelo caráter combativo. Passado este período intenso de descobertas, o que hoje interessa a Paula são escritores contemporâneos de ficção de qualquer nacionalidade "que fantasiem a realidade, que anda muito crua para o meu gosto". Se nos anos 70 o que chamou sua atenção nos autores angolanos foi justamente a abordagem de temas que lhe eram próximos, hoje ela acha "que cada vez mais as literaturas não têm fronteiras e os escritores são menos definíveis, e isso agrada-me muito”. Atualmente, os 
angolanos que figuram entre os autores de sua predileção, e que só foram citados quando fizemos a pergunta diretamente, são Ondjaki, José Eduardo Agualusa e Mena Abrantes, os dois primeiros de uma geração posterior à que comenta em seus relatos iniciais. Já Mena Abrantes possui uma obra mais detidamente dedicada ao teatro.

Cassé revela apreço por diversos autores angolanos, citando António Jacinto, Ernesto Lara Filho, Aires de Almeida Santos, Alexandre Dáskalos, António Cardoso, Henrique Guerra, Luandino Vieira, Alda Lara, Maurício Gomes, Ermelinda Xavier. Sem que Cassé explicite isso, são todos autores ligados de alguma maneira ao nacionalismo angolano, tendo participado dos movimentos políticos ou culturais de combate ao regime colonial, como as publicações Mensagem e Cultura II ou o Movimento dos Novos Intelectuais de Angola e o próprio MPLA. Entre suas preferências atuais figuram os angolanos Henrique Abranches e Pepetela, dentre outros nomes do universo lusófono. Respondendo a uma pergunta aberta acerca de suas predileções atuais, destacamos que Cassé, que teve e tem acesso à literatura universal, cita angolanos, portugueses e brasileiros, todos autores que escrevem em sua língua materna, guardadas, obviamente, suas variantes.

Nas leituras de Anabela figuram autores canônicos de países como Brasil, Portugal, Rússia, França e de outras nações de América do Sul. Mais recentemente ela cita um autor turco e de outros países da África. Aos angolanos foi reservado o lugar da literatura de certa forma imposta. É nesta chave que aparecem os únicos autores que ela cita - Uanhenga Xitu, Pepetela e Manuel Rui -, a quem ela atribui uma escrita orientada e educativa. Anabela mostra um entusiasmo com a instituição literária angolana, tendo apoiado o governo nas campanhas de alfabetização, por exemplo, e reconhece algumas mudanças que o Estado implementou. Mas não parece ter se encantado com a produção de seus conterrâneos. Ela registra, inclusive, uma desconfiança com essa literatura, quando descobre os autores que classifica como anticomunistas e que permitem a comparação com a produção angolana. .

Para Jorge, que revelou seu interesse por romances históricos, dramas e a poesia engajada, a exemplo da obra de Pablo Neruda, alguns autores angolanos foram lidos na juventude, como Arnaldo Santos, de quem afirma ter gostado muito. Posteriormente ele se encontrou com Boaventura Cardoso, António Jacinto e Luandino Vieira. O escritor Pepetela lhe chega apenas depois da Revolução dos Cravos. Eles são citados sem deferência especial, enquanto outros autores contribuíram mais definitivamente para sua formação, como Dumas, Dostoievski ou Jorge Amado. Desde cedo, relembremos, ele 
demonstrou grande apreço pela Banda Desenhada, sem ter travado conhecimento, é de se notar, com a obra de Henrique Abranches, um dos nomes mais significativos da BD angolana.

No balanço feito no capítulo anterior, tentamos demonstrar como o projeto literário em curso em Angola privilegiou, a partir de critérios como autores mais editados, vendidos e premiados, as obras de Agostinho Neto, Luandino Vieira e Pepetela. Salta aos olhos que nenhum dos leitores cite ter lido Neto ou admitido ser impactado por sua poesia. Apenas Jorge faz menção à faceta poética do presidente, ainda que não para informar que acompanhou sua obra. Já Pepetela foi lido por Paula, Jorge, Anabela e Cassé, mas apenas este último demonstrou mais contato e interesse por sua obra. Luandino é ausência apenas nas memórias de Anabela, tendo sido lido e apreciado pelos outros entrevistados. Paula e Cassé foram impactados sobremaneira por sua obra, sugerindo reconhecer que, dos três escritores, Luandino foi o que apresentou uma maior novidade estética.

Os leitores a que tivemos acesso, diferentemente daqueles que identificamos que o projeto encarnado pela UEA e pelo Inald pretendia formar, possuem uma característica singular que, em nossa opinião, permite que teçam uma leitura crítica do momento histórico que vivenciaram: eles já eram leitores antes de travarem contato com essa literatura impulsionada pelo Estado angolano. Possuindo um repertório mais amplo de livros e leituras, tinham condições de cotejar autores e obras, e, detendo meios econômicos e vias privilegiadas para acessar o livro, inclusive o livro estrangeiro, não se restringiram a abraçar a literatura angolana. Isso não quer dizer que não tenham se encantado com essa produção literária, que marcou principalmente Paula e Cassé. Mas ela veio se juntar a muitos outros livros e histórias, ocupando não um lugar de destaque no panteão particular de cada leitor.

O caso de Anabela se distancia dos demais por dois motivos e nos oferece uma outra perspectiva: sendo mais jovem, ela cursou a maior parte do seu ensino nos anos da Angola independente; é possível aferir, por seu discurso e leituras iniciais, que a biblioteca a qual tinha acesso era menos variada que a dos outros interlocutores. Desde jovem, portanto, travou contato com escritores angolanos como Uanhenha Xitu e Pepetela que, em sua fala, todos os angolanos teriam lido. Ela precisou de um afastamento, no tempo e no espaço, para entender aquela produção e construir sua crítica: apenas quando foi à Praga e teve contato com outra realidade e com outra literatura, ela pode reelaborar suas leituras. Para ela, essa literatura, que entendeu como 
orientada, parece ter significado uma espécie de deslealdade. Talvez por isso ela seja, entre os quatro entrevistados, a que privilegie leituras mais universais, em detrimento do universo angolano.

As transformações que assinalamos, no que diz respeito a uma institucionalização da literatura, com edições de tiragens significativas e uma distribuição mais ampla, foram percebidas pelos leitores, ainda que de maneiras distintas. Jorge é reticente, lembrando do alto número de analfabetos, afirmando que os livros, embora distribuídos ou vendidos a preço módico, eram poucos, e demarcando sua posição em relação ao Estado, que teria estancado seu incentivo quando percebeu que a literatura poderia despertar reflexões indesejadas. Ele cita que esse breve período de euforia teria terminado em 1977. Suas percepções, podemos depreender, passam por uma leitura política: se o 27 de Maio foi um golpe duro nos anseios de muitos angolanos, não foi necessariamente nesta data que a produção livreira caiu. O período entre 1976 e 1978, relembremos os números coletados por Hamilton, contou com mais de 455 mil exemplares publicados pela União, enquanto a produção apenas do ano de 1979 se equipara à do último triênio. Em 1979 e no início da década de 1980 também vemos a emergência dos prêmios literários, que certamente movimentaram o cenário literário angolano. Apenas em 1983 haveria uma queda na produção, por conta da escassez do papel e de outras consequências da guerra civil. O que ficou retido nas memórias de Jorge, no entanto, foi que a crise política teria se estendido ao campo cultural.

Já para Cassé, as ações da UEA teriam incrementado em muito a produção do livro no país, incentivando não apenas a literatura angolana. A sua percepção é de que havia muitos livros e a preços acessíveis. A mudança de cenário viria com a abertura do mercado ao capital estrangeiro, no início dos anos 90, que, segundo ele "resultou num ultra-liberalismo sem limites", de maneira que a situação hoje em Angola "é muito pior do que antes da independência”. Nas memórias de Paula, o período do pós independência foi de euforia, como defendem muitos dos protagonistas que falaram em nome da UEA e do Inald: "Publicava-se muito. Depois também se recebia muita coisa de fora (...). Mas sobretudo havia muitos livros para comprar. Não havia comida, mas havia livros".

Lembramos que, para esses leitores, o livro não era escasso no período anterior, de regime colonial. O que, para eles, não existia ou havia de maneira muito pontual era o livro de autoria de angolanos, que passa então a ser facilmente encontrado nas 
cidades, conforme apontam suas recordações. Em maior ou menor medida, os entrevistados perceberam um aumento na produção e circulação do livro, assim como o fato de serem oferecidos a baixo custo, o que não necessariamente associam a um subsídio do governo. Anabela é a única a explicitar esse papel, afirmando, sobre a distribuição de livros que "era tudo do Estado". A União dos Escritores Angolanos tem sua importância reconhecida nas falas de Cassé e Anabela, que atribuem à instituição uma atuação relevante na promoção do livro e da literatura angolana. Ao Inald, recordam os entrevistado, coube sobretudo a edição de livros técnicos.

Paula, Cassé, Anabela e Jorge, os leitores que se dispuseram a compartilhar conosco suas memórias de leitura, como já dissemos, certamente pertencem, e sobretudo no período estudado, pertenceram a uma pequena elite de letrados, que viram desde cedo o livro fazer parte da sua vida. O projeto literário que emanava de instituições ligadas ao governo, que tentamos redesenhar no capítulo anterior, voltava-se para um público mais amplo, mas nem por isso deixou de impactar esses leitores. Apesar de, por alguns caminhos, pertencerem a um grupo relativamente homogêneo, os quatro entrevistados possuem origens distintas e, em que pese seu contato estreito com a literatura, suas trajetórias são singulares. Elas revelaram, mais que diferentes formas de ler e de lidar com a literatura, uma leitura sobre a própria narrativa angolana. E também permitiram entrever um aspecto da dinâmica do complexo de instituições e atores que compõem um sistema literário, reafirmando que a literatura não é estanque como uma prateleira de livros enfileirados, mas está sujeita a múltiplos olhares e interações. 


\section{5- CONSIDERAÇÕES FINAIS}

Se uma pesquisa nasce de uma curiosidade que acaba por desembocar em um objeto de estudo, como aventado nas considerações iniciais desta dissertação, chegar ao fim do trabalho não significa necessariamente que estamos pisando em terreno firme. Isso porque no transcurso da investigação outras perguntas vão surgindo, nossos olhares vão se deslocando, as bifurcações parecem ser inesgotáveis. Esta dissertação padeceu, como acreditamos que ocorre em grande parte dos casos, de muitos questionamentos e da dificuldade para traçar um recorte preciso, mesmo quando já corriam muitos meses no programa da pós-graduação. Porém, mais que colocar em dúvida nossos caminhos, essa trajetória por vezes claudicante nos pareceu frutífera justamente por expor a complexidade do objeto de que tentamos nos apropriar. Afinal, nossa opção foi por nos afastar do texto literário, ele mesmo de difícil apreensão, embora por vezes o imaginemos estanque em suas páginas, para refletir sobre aqueles elementos que Antonio Candido classifica de extra literários: livros, leitores, leituras, instituições e atores de um período distante de uma longínqua nação. Foi desafiante e, tendo em vista a intricada urdidura que nos propomos enfrentar, acreditamos que colhemos resultados satisfatórios.

O maior deles certamente foram os dados, informações e memórias que a generosidade de todos os nossos interlocutores nos permitiu organizar e registrar. Para além do fato de que um montante relevante dessas informações encontrava-se disperso, temos a convicção de que muito do material colhido traz olhares e perspectivas que até então não tinham sido oferecidos: a partir de um trabalho de escuta, pudemos trazer à tona memórias, opiniões, reflexões e trajetórias que falam por si.

Mapeamos as atividades de duas instituições que sem dúvida responderam massivamente, durante o período analisado, pelo que chamamos de projeto literário em curso no país: a União dos Escritores Angolanos e o Instituto Nacional do Livro e do Disco. Publicando livros e promovendo ações de incentivo à leitura, as organizações trabalharam para formar um leitor engajado com as causas nacionais: educar, servir ao projeto do Estado e fortalecer a identidade nacional são algumas das missões de que a literatura angolana foi encarregada naquele período. O projeto literário angolano, no entanto, oferecia espaço para alguma liberdade criativa, buscando mais que operar em favor de uma causa política. A tríade de autores que se destacam por terem sido mais 
vendidos, publicados ou premiados parece dar conta da versatilidade desse projeto: Agostinho Neto, Luandino Vieira e Pepetela ofereceram com suas obras, respectivamente, um compromisso com a luta política e o Estado angolano, com a inovação estética e com o retrato da angolanidade, muitas vezes de maneira pedagógica.

Conseguimos, por fim, dar materialidade a um leitor que figurava no imaginário do país desde as primeiras iniciativas, ainda na década de 1940, de produzir uma literatura de cariz angolano, feita para angolanos. Traçando algumas trajetórias de sujeitos que, se não representam os múltiplos perfis de leitores possíveis, tampouco deixam de ser significativas, encontramos em meio a uma Angola com mais de $90 \%$ de analfabetos leitores de literatura angolana e universal. Leitores que se formaram em bibliotecas particulares, nas quais figuravam clássicos europeus e brasileiros, mas também que estiveram sujeitos ao ensino de uma literatura orientada às causas nacionais na escola que frequentaram. Leitores que nos ofereceram um resgate da paisagem literária angolana nos anos pós-independência, em cotejamento com o período colonial. Leitores que se entusiasmaram e se decepcionaram com os programas de promoção do livro e da leitura neste período. Leitores que participaram ativamente desse processo, sendo alfabetizadores nas campanhas do governo ou se transformando em escritores. Leitores que se permitiram arrebatar pela literatura angolana que emergia. Ou que colocaram esses autores simplesmente ao lado de inúmeros outros que figuram em suas bibliotecas afetivas. Leitores que nos auxiliaram a reler Angola.

É com esta mirada multifacetada que encerramos este trabalho, certos de que para cada olhar diferente que recair sobre a literatura angolana, ela se abrirá em múltiplas leituras. 


\section{BIBLIOGRAFIA}

ANGOLA, Ministério da Educação. Balanço de Implementação da $2^{a}$ Reforma Educativa em Angola. Luanda: 2011.

ABDALA JR., Benjamin. De vôos e Ilha: Literatura e Comunitarismos. São Paulo: Ateliê Editorial, 2003.

ABRAHÃO, Maria. Memórias, narrativas e pesquisa autobiográfica. Revista História da Educação, ASPHE/FaE/UFPel, Pelotas, nº 14, set. 2003.

ABREU, Márcia. Diferentes formas de ler. Comunicação apresentada na mesa-redonda Práticas de leitura: história e modalidades. XXIV Congresso Brasileiro de Ciências da Comunicação - Intercom. Campo Grande, 2001. Acessado em http://www.unicamp.br/iel/memoria/Ensaios/ em 15 de julho de 2015

ABREU, Márcia. Cultura letrada - literatura e leitura. São Paulo: Editora Unesp, 2006.

ABREU, Márcia (org.). Leitura, História e História da Leitura. Campinas: Mercado das Letras/ALB, 2000.

ANDERSON, Benedict. Comunidades Imaginadas. São Paulo: Cia. das Letras, 2006.

BARTHES, Roland. “A morte do autor”. In: O rumor da língua. São Paulo, Brasiliense, 1988.

BOSI, Alfredo, "Narrativa e Resistência", in: Literatura e Resistência. São Paulo: Cia. Das Letras, 2002.

BOSI, Ecléa. Memória e Sociedade - lembrança de velhos. São Paulo: Cia. das Letras, 1994.

CABRAL, Amílcar. "Libertação Nacional e Cultura”, In: SANCHES, Manuela Ribeiro (org), Malhas que os Impérios tecem. Lisboa: Edições 70, 2011.

CADERNO ESPECIAL LAVRA \& OFICINA. Luanda: União dos Escritores Angolanos, 1979.

CANDIDO, Antonio. Formação da Literatura Brasileira-Momentos Decisivos. Rio de Janeiro: Ouro sobre Azul, 2012.

CANDIDO, Antonio. Literatura e Sociedade. Rio de Janeiro: Ouro sobre Azul, 2010.

CANDIDO, Antonio. Vários escritos. Rio de Janeiro: Ouro sobre Azul, 2004.

CANDIDO, Antonio. "Literatura e subdesenvolvimento". In: A educação pela noite e outros ensaios. São Paulo: Ática, 1987. 
CAPATTO, R.M. Nas malhas do leitor - um estudo de teses e dissertações sobre leitura/recepção de textos (1980-2003). Assis: UNESP, 2005.

CASANOVA, Pascale. A República Mundial das Letras. São Paulo: Estação Liberdade, 2002.

CHAMOISEAU, Patrick. Écrire en pays dominé. Paris, Gallimard, 1997.

CHARTIER, Roger. Cultura escrita, literatura e história - Conversas de Roger Chartier com Carlos Aguirre Anaya, Jesús Anaya Rosique, Daniel Goldin e Antonio Saborit. Porto Alegre: Artmed, 2001.

CHARTIER, Roger (Org.). Práticas da leitura. São Paulo: Estação Liberdade, 1996.

CHARTIER, Roger. A ordem dos livros - leitores, autores e bibliotecas na Europa entre os séculos XIV e XVIII. Brasília: Editora UNB, 1994.

CHARTIER. Roger. A aventura do livro - do leitor ao navegador - Conversações com Jean Lebrun. São Paulo: Editora Unesp - Imprensa Oficial, 1988

CHAVES, Rita. A formação do romance angolano. São Paulo: Fundo Bibliográfico de Língua Portuguesa. 1999

CHAVES, Rita; MACÊDO, Tania; VECCHIA, Rejane (org.). A kinda e a misanga. Encontros brasileiros com a literatura angolana. São Paulo: Cultura Acadêmica; Luanda: Editorial Nzila, 2007.

COMPAGNON, Antoine. O demônio da teoria - Literatura e senso comum. Belo Horizonte: Editora UFMG, 2006.

CORTESÃO, Armando Zuzarte. In: Boletim Geral das Colónias . I - 001 PORTUGAL. Agência Geral das Colónias, Vol. I - 1, 1925. Acessado em www.memoria-africa.ua.pt

COSME, Leonel. “A Imbondeiro no Brasil” In: Revista Ecos vol.17, Ano XI, n 02 (2014).

DARNTON, Robert. O beijo de Lamourette - mídia, cultura e revolução. São Paulo: Companhia das Letras, 2010.

ECO, Umberto. Lector in fabula. São Paulo: Perspectiva, 1988.

ERVEDOSA, Carlos. Roteiro da Literatura Angolana. Luanda: União dos Escritores Angolanos, 1985.

ERVEDOSA, Carlos. A literatura angolana. Lisboa: Casa dos Estudantes do Império, 1963.

FANON, Franz. Os condenados da terra. Rio de Janeiro: Civilização Brasileira, 1979. 
FISCHER, Steven Roger. História da Leitura. São Paulo: Editora Unesp, 2006.

FISH, Stanley. Is there a text in this class? São Paulo: Alfa, 1992.

GAZETA LAVRA \& OFICINA, publicação da União dos Escritores Angolanos. Luanda: ${ }^{\circ}$ 4, janeiro de 1979

GAZETA LAVRA \& OFICINA, publicação da União dos Escritores Angolanos. Luanda: ${ }^{\circ} 5$, fevereiro de 1979

GAZETA LAVRA \& OFICINA, publicação da União dos Escritores Angolanos. Luanda: $\mathrm{n}^{\circ}$ 6, março de 1979

GAZETA LAVRA \& OFICINA, publicação da União dos Escritores Angolanos. Luanda: $\mathrm{n}^{\circ} 7$, abril de 1979

GAZETA LAVRA \& OFICINA, publicação da União dos Escritores Angolanos. Luanda: $\mathrm{n}^{\circ} 8$, maio de 1979

GAZETA LAVRA \& OFICINA, publicação da União dos Escritores Angolanos. Luanda: $\mathrm{n}^{\circ}$ 9-10, junho/julho de 1979

GAZETA LAVRA \& OFICINA, publicação da União dos Escritores Angolanos. Luanda: no 11-12, agosto/setembro de 1979

GAZETA LAVRA \& OFICINA, publicação da União dos Escritores Angolanos. Luanda: ${ }^{\circ} 13$, outubro de 1979

GAZETA LAVRA \& OFICINA, publicação da União dos Escritores Angolanos. Luanda: ${ }^{\circ} 14$, novembro de 1979

GAZETA LAVRA \& OFICINA, publicação da União dos Escritores Angolanos. Luanda: $n^{\circ} 15$, dezembro de 1979

GAZETA LAVRA \& OFICINA, publicação da União dos Escritores Angolanos. Luanda: ${ }^{\circ}$ 16, janeiro de 1980

GAZETA LAVRA \& OFICINA, publicação da União dos Escritores Angolanos. Luanda: $n^{\circ} 17-18$, fevereiro/março de 1980

GAZETA LAVRA \& OFICINA, publicação da União dos Escritores Angolanos. Luanda: no $19-20$, abril/maio de 1980

GAZETA LAVRA \& OFICINA, publicação da União dos Escritores Angolanos. Luanda: nº 21-22, junho/julho de 1980

GAZETA LAVRA \& OFICINA, publicação da União dos Escritores Angolanos. Luanda: ${ }^{\circ}$ 23-24, agosto/setembro de 1980 
GAZETA LAVRA \& OFICINA, publicação da União dos Escritores Angolanos. Luanda: nº 25-26-27, outubro/novembro/dezembro de1980

GAZETA LAVRA \& OFICINA, publicação da União dos Escritores Angolanos. Luanda: $\mathrm{n}^{\circ}$ 28-29, 30, janeiro/fevereiro/março de 1981

GAZETA LAVRA \& OFICINA, publicação da União dos Escritores Angolanos. Luanda: no 31-32-33, abril/maio/junho de 1981

GAZETA LAVRA \& OFICINA, publicação da União dos Escritores Angolanos. Luanda: $n^{\circ}$ 34-39, julho/dezembro de 1981

GAZETA LAVRA \& OFICINA, publicação da União dos Escritores Angolanos. Luanda: $n^{\circ}$ 40-45, janeiro/junho de 1982

GAZETA LAVRA \& OFICINA, publicação da União dos Escritores Angolanos. Luanda: $n^{\circ}$ 46-51, julho/dezembro de 1982

GAZETA LAVRA \& OFICINA, publicação da União dos Escritores Angolanos. Luanda: ${ }^{\circ} 52$, outubro de 1985

GAZETA LAVRA \& OFICINA, publicação da União dos Escritores Angolanos. Luanda: $n^{\circ} 53$, dezembro de 1985

GUIMARÃES, Hélio de Seixas. Os leitores de Machado de Assis: O romance machadiano e o público de literatura no século 19. São Paulo: Nankin Editorial Editora da Universidade de São Paulo, 2004.

GOVERNO DE ANGOLA (2010). Boletins de Estatísticas Sociais 2005 - 2008. Luanda, 2010.

HALL, Stuart. “Quando foi o pós-colonial?” In: Da Diáspora: identidades e mediações culturais. Belo Horizonte: Editora UFMG, 2003.

HAMILTON, Russell G. Literatura Africana, Literatura Necessária - Angola. Lisboa: Edições 70, 1975.

HAMILTON, Russell G. "A literatura dos PALOP e a Teoria Pós-Colonial”. Revista Via Atlântica. $\mathrm{N}^{\circ}$ 3, dezembro de 1999, 12 - 22.

ISER, Wolfgang. O ato da leitura. São Paulo: Editora 34, 1996.

JACINTO, Antonio. Sobreviver em Tarrafal de Santiago. Luanda: União dos Escritores Angolanos, 2013.

JAUSS, Hans Robert. A história da literatura como provocação à teoria literária. São Paulo: Ática, 1994.

JAUSS, Hans Robert. "A estética da recepção - colocações gerais". In: LIMA, Luiz Costa (org.). A literatura e o leitor. Rio de Janeiro: Paz e Terra, 1979. 
KANDJIMBO, Luís. Apologia de Kalitangi - Ensaio e Crítica. Luanda: INALD, 1997.

LAJOLO, Marisa \& ZILBERMAN, Regina. A formação da leitura no Brasil. São Paulo: Ática, 1996.

LAJOLO, Marisa. Do mundo da leitura para a leitura do mundo. São Paulo: Ática, 1993.

LARANJEIRA, Pires. Literaturas Africanas de Expressão Portuguesa. Lisboa: Universidade Aberta, 1995.

LEITE, Ana Mafalda. "Literaturas Africanas e Pós-Colonialismo". In: Literaturas Africanas e Formulações Pós-Coloniais. Lisboa: Colibri, 2003.

LIBERATO, Ermelinda. Avanços e retrocessos da educação em Angola. Rev. Bras. Educ., Rio de Janeiro , v. 19, n. 59, p. 1003-1031, Dec. 2014 . Available from <http://www.scielo.br/scielo.php?script=sci_arttext\&pid=S1413-

$24782014000900010 \& \operatorname{lng}=\mathrm{en} \& n r m=$ iso $>$. access on 20 Mar. 2017.

LIMA, Isabel Pires de. Em busca de uma nova pátria: o romance de Portugal e Angola após a descolonização. Revista Via Atlântica. Revista Via Atlântica. $\mathrm{N}^{\circ}$ 1, março de 1997. P. $128-141$.

LOURENÇO, Eduardo. A Nau de Ícaro. São Paulo: Companhia das Letras, 2001.

LYONS, Martyn. A história da leitura de Gutenberg a Bill Gates. In: A palavra impressa - histórias da leitura no século XIX. LYONS, Martyn \& LEAHY, Cyana. Rio de Janeiro: Casa da Paulavra, 1999.

MACÊDO, Tania Celestino de. Luanda, cidade e literatura. São Paulo: Editora Unesp; Luanda: Nzila, 2008.

MACÊDO, Tania Celestino de. Visões do mar na literatura angolana contemporânea. Revista Via Atlântica. No 3, dezembro de 1999, 48 - 57.

MACÊDO, Tania Celestino de. A representação literária de Luanda - uma "ponte" entre Angola, Brasil e Portugal. Revista Via Atlântica. No 1, março de 1997, 119 - 127.

MACÊDO, Tania \& CHAVES, Rita. Literaturas de Língua Portuguesa: marcos e marcas. Arte e Ciência Editora, 2007

MANGUEL, Alberto. Uma história da leitura. São Paulo: Companhia das Letras, 1997.

MARTINHO, Ana Maria. Cânones literários e educação: os casos angolanos e moçambicanos. Lisboa: Fundação Calouste Gulbenkian, 2001.

MATA, Inocência. "O pós-colonial nas literaturas africanas de língua portuguesa". Texto apresentado no X Congresso Internacional da ALADAA (Associação LatinoAmericana de Estudos de Ásia e África) sobre Cultura, Poder e Tecnologia: África e 
Ásia face à globalização - Universidade Cândido Mendes, Rio de Janeiro - 26 a 29 de outubro de 2000.

MEMMI, Albert. Retrato do colonizado precedido pelo retrato do colonizador. Rio de Janeiro: Paz e Terra, 1977.

MONTELLO, Josué. Sempre serás lembrada. Rio de Janeiro: Nova Fronteira, 1999.

NAKAGOME, P. T. A vida e a vida do leitor: um conceito formado no espelho. São Paulo: Universidade de São Paulo, 2015.

NETO, Agostinho. Sagrada Esperança. Luanda: União dos Escritores Angolanos, 2013.

NGULUVE, A. K. Política educacional angolana (1976 - 2005): Organização, Desenvolvimento e Perspectivas. São Paulo, Universidade de São Paulo, 2006

NOA, Francisco. "Literatura Colonial em Moçambique: o paradigma submerso" In: Via Atlântica, nº 3, dezembro de 1999.

ONDJAKI. Os da minha rua. Rio de Janeiro: Língua Geral, 2007.

ORNELLAS, Ayres de. A nossa administração colonial: o que é e o que deve ser. Congresso Nacional Colonial, 1903.

PÉLISSIER, Reneé \& WHELLER, Douglas. História de Angola. Lisboa: Tinta da China, 2013.

PEPETELA. Mayombe. Lisboa: Dom Quixote, 1989.

PEPETELA. As aventuras de Ngunga. Luanda: UEA, 1979.

PEPETELA. O planalto e a estepe. São Paulo: Leya, 2009.

PESTANA, Nelson. As dinâmicas da sociedade civil em Angola. Lisboa: Centro de Estudos Africanos, 2013.

PETIT, Michèle. A arte de ler ou como resistir à adversidade. São Paulo: Editora 34, 2009.

PETIT, Michèle. Os jovens e a leitura - uma nova perspectiva. São Paulo: Editora 34, 2008.

PINTO, Alberto Oliveira. História de Angola - Da pré-história ao início do século XXI. Lisboa: Mercado de Letras, 2015.

PINTO, Alberto Oliveira. Angola e as retóricas coloniais. Lisboa: Mercado de Letras, 2012. 
PORTELLI, A. O que faz a história oral diferente. In: Cultura e Representaçào. São Paulo: Projeto História, no. 14. Educ. 1997

REIS, Roberto. Cânon. In: Jobim, José Luís (org.). Palavras de Crítica. Rio de Janeiro, Imago, 1992.

RIAÚZOVA, Helena. Dez anos de literatura angolana: ensaio sobre a moderna literatura angolana. Luanda: União dos Escritores Angolanos, 1986.

RUBIO, Maria José \& VARAS, Jesús. El análisis de la realidad en la intervención social - métodos y técnicas de investigación. Madrdi: Editorial CCS, 2004.

RUI, Manuel. Quem me dera ser onda. Rio de Janeiro: Gryphus, 2005.

SAID, Edward. "Territórios sobrepostos e histórias entrelaçadas", In: Cultura e Imperialismo. São Paulo: Cia. das Letras, 2011.

SANTILLI, Maria Aparecida. Estórias Africanas. São Paulo: Ática, 1985.

SANTOS, Arnaldo. Kinaxixe. Luanda: UEA, 1985.

SANTOS, D. A. Sagas familiares e narrativas de fundação engajadas de Érico Veríssimo e Pepetela. São Paulo: Universidade de São Paulo, 2013.

SARTRE, Jean Paul. "Por que escrever?" In . O que é literatura? São Paulo: Ática, 2004, p. $43-53$.

SECCO, Carmen Tindó. A literatura e a arte em Angola no pós-independência. In: Revista Conexão Letras. Volume 8, número 9, Ano 2013, UFRGS. Porto Alegre.

SHOHAT, Ella \& STAM, Robert. Entrevista publicada na Revista Estudos Feministas, Florianópolis, 21(2): 336, maio-agosto/2013.

TAVARES, Ana Paula. Cinquenta Anos de literatura angolana. Revista Via Atlântica. No 3, dezembro de 1999, $124-130$.

TODOROV, Tzvetan. Literatura em perigo. Rio de Janeiro: Difel, 2009.

TURCHI, Maria Zaira \& SILVA, Vera Maria Tietzmann, orgs. "Leitor formado, leitor em formação - leitura literária em questão", São Paulo: Cultura Acadêmica; Assis, SP: ANEP: 2006.

VIEIRA, Luandino. Luuanda. São Paulo: Companhia das Letras, 2006.

VIEIRA, Luandino. Nós os da Maukusu. Luanda: UEA, 1989.

WARKEN, E. A recepção de Machado de Assis por jovens leitores do século XXI. Assis: UNESP, 2015. 
WHEELER, Douglas \& PÉLISSIER, René. História de Angola. Lisboa: Tinta da China, 2013.

XITU, Uanhenga. Mestre Tamoda e outros contos. Lisboa: Edições 70, 1977.

ZILBERMAN, Regina. Fim do livro, fim dos leitores? São Paulo: Editora Senac, 2001.

\section{Sites consultados}

CASA COMUM

http://casacomum.org/cc/arquivos?set=e 10883, Último acesso em 03 de fevereiro de 2017

CHAVES, Rita. 2012, "Entrevista com Rita Chaves, professora brasileira de literatura africana". Entrevista para a União dos Escritores Angolanos. Disponível em http://www.ueangola.com/entrevistas/item/774-entrevista-com-rita-chaves-professorabrasileira-de-literatura-africana Último acesso em 03 de agosto de 2013.

FONSECA, Nazareth. 2010, "Só com o fortalecimento de uma massa de leitores críticos é que a crítica se fortalecerá no país". Entrevista para a União dos Escritores Angolanos. Disponível em http://www.ueangola.com/entrevistas/item/778-s\%C3\%B3-com-ofortalecimento-de-uma-massa-de-leitores-cr\%C3\%ADticos-\%C3\%A9-que-a-critica-sefortalecer\%C3\%A1-no-pa\%C3\%ADs-nazareth-fonseca Último acesso em 03 de agosto de 2013.

KANDJIMBO, Luís. “A Literatura Angola, a formação de um cânone literário mínimo de Língua Portuguesa e as estratégias da sua difusão e ensino". Texto apresentado ao Seminário para Edificação do Instituto Internacional de Língua Portuguesa (IILP), realizado pela CPLP. Lisboa 5-8 de Junho de 2001. Disponível em http://www.ueangola.com/criticas-e-ensaios/item/58-a-literatura-angola-aforma\%C3\% A7\% C3\% A3o-de-um-c\%C3\%A2none-liter\%C3\%A1riom\%C3\%ADnimo-de-1\%C3\%ADngua-portuguesa-e-as-estrat\%C3\%A9gias-da-suadifus\%C3\%A3o-e-ensino* Último acesso em 03 de agosto de 2013.

PEPETELA. 2010, “Algumas questões sobre a literatura angolana". Disponível em http://www.ueangola.com/criticas-e-ensaios/item/122-algumas-quest\%C3\%B5es-sobrea-literatura-angolana Último acesso em 03 de agosto de 2013.

\section{PRÊMIO SONANGOL}

http://www.sonangol.co.ao/Portugu\%C3\%AAs/Sociedade\%20e\%20Ambiente/Pr\%C3\% A9mio\%20de\%20Literatura/Paginas/Pr\%C3\%A9mio-de-Literatura.aspx, Último acesso em 05 de janeiro de 2017

QUINO, Antonio. 2011, “Todos queremos escrever, mas poucos querem ler". Entrevista para a União dos Escritores Angolanos. Disponível em http://www.ueangola.com/entrevistas/item/882-todos-queremos-escrever-mas-poucosquerem-ler-diz-ant\%C3\%B3nio-quino Último acesso em 03 de agosto de 2013. 
Anexo A - Anúncio da Livraria Lello no Boletim Cultural do Huambo de 1948

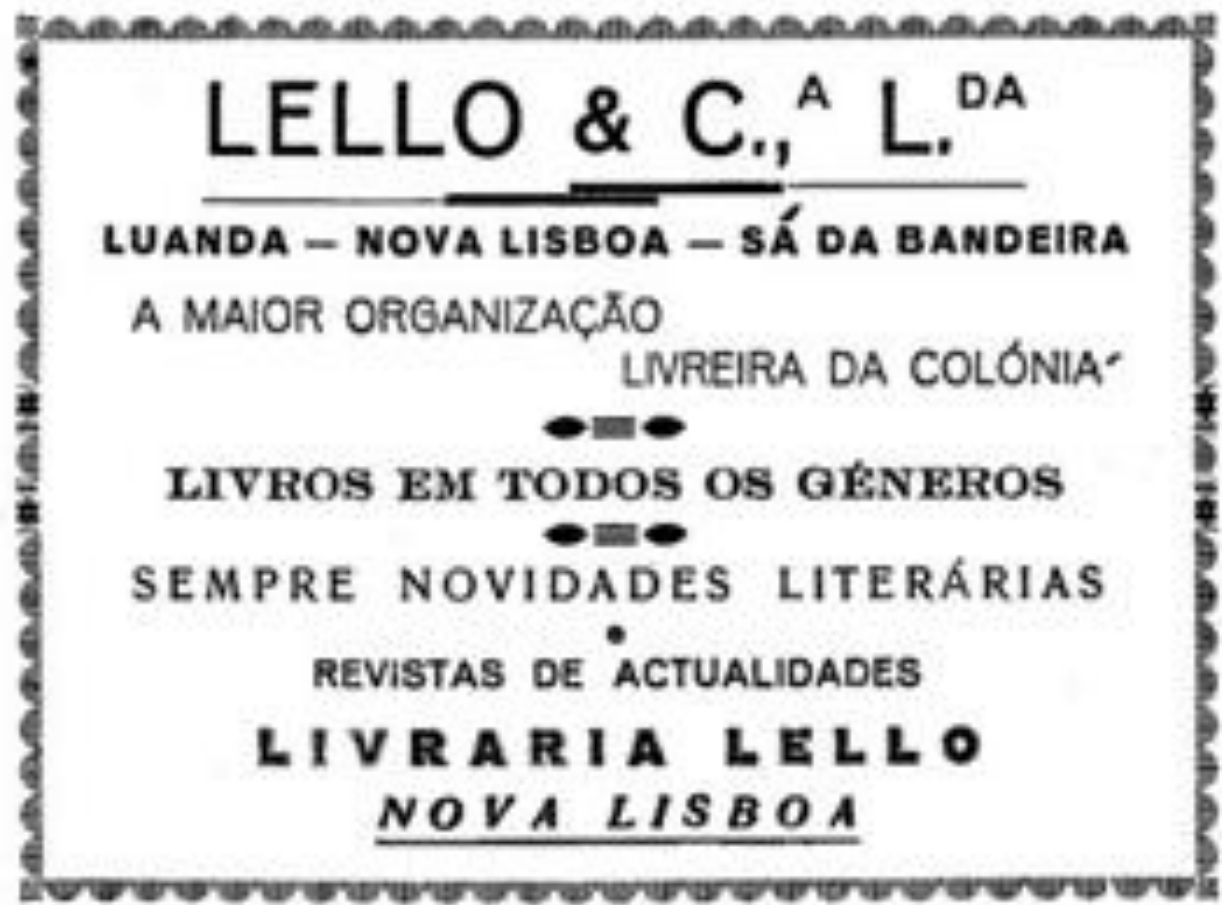


Anexo B - Anúncio da Biblioteca Municipal de Nova Lisboa (hoje Huambo) no Boletim Cultural do Huambo de 1948

\title{
BIBLIOTECA MUNICIPAL
}

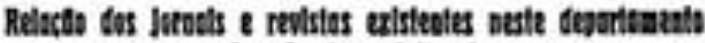 \\ tas Servinss catterals}

\author{
Oeidente \\ Brotéria \\ Vórtico \\ Boletim Beral das Colónias \\ Boletim da Secledede de Gecorafía de Lisboa \\ Anais do Instituto de Medicina Troplcal \\ Gazota das Aldelas \\ Joenal do Módice \\ Mundo Hispanico \\ Reviata do Uitramar \\ Ver o Cret \\ Lorousse Mansual \\ Arquives de Angola \\ A Fazenda \\ Mensário Administrativo \\ Ravista do Arquivo Municipat ds \&. Paulo \\ Boletim Cultural da Guinb Portuguess \\ Actividade Econdmica de Angola \\ Lisbon-Courier \\ Boletim Messal do Estatlstica do Angela \\ Noticlas de Portugal (SNI) \\ Voz de Angols \\ Vor do Planalto \\ Dibrilo de Luanda \\ A perovincia de Angela \\ Jornal de Benguala \\ O Intransigente \\ Diario da Manha \\ Angola Norte \\ A Hulla \\ Neticias da Hufla \\ A Vida Mundial \\ Traço de Uniaso
}


Anexo C - Lista de membros fundadores da União dos Escritores Angolanos (UEA)

Adriano Botelho Vasconcelos

Aires de Almeida Santos

Agostinho Neto

António Cardoso

António Jacinto

Arlindo Barbeitos

Antero Abreu

Aristides Van-Dúnem

Arnaldo Santos

Artur Carlos Maurício Pestana dos Santos (Pepetela)

Boaventura Cardoso

Carlos Pimentel

Domingos Van-Dúnem

Eugénio Ferreira

Fernando Costa Andrade

Fonseca Wochay

Garcia Bires

Henrique Abranches

Henrique Guerra

João Melo

Jofre Rocha

José Luandino Vieira

Manuel Rui

Manuel Pacavira

Manuel Bernardo de Sousa

Mario de Alcântara Monteiro

Maria Eugénia Neto

Octaviano Correia

Raúl David

Rosario Marcelino

Ruy Duarte de Carvalho

Samuel de Sousa

Uanhenga Xitu 


\section{Anexo D - Estatutos da União dos Escritores Angolanos (UEA)}

Artigo $1^{\circ}$

1. A União dos Escritores Angolanos (UEA) é uma associação com personalidade jurídica, constituída por escritores angolanos.

2. Consideram-se escritores, os autores de textos e obras de pura criação literária e os autores de quaisquer outros textos ou obras que, pela originalidade da concepção ou virtudes de estilo, possuam apreciáveis características literárias.

Artigo $2^{\circ}$ A União dos Escritores Angolanos (UEA) terá a sua sede em Luanda, podendo contudo, instalar Delegações ou constituir Comissões Provinciais ou Regionais onde e quando as circunstâncias o permitam.

Artigo $3^{\circ}$ A União dos Escritores Angolanos (UEA) assenta a sua actividade nos seguintes princípios fundamentais:

a) Independência intelectual e orgânica;

b) Liberdade criativa;

c) Promoção dos valores culturais nacionais e de todas as conquistas universais; posicionamento contra todas as formas de discriminação étnica, racial, sexual, nacional, cultural e outras;

d) Profunda e activa solidariedade humana;

1. Os fins da União dos Escritores Angolanos (UEA) são os seguintes:

a) Representar os escritores angolanos membros da UEA;

b) Promover a defesa da cultura angolana como património da Nação;

c) Estimular os trabalhos tendentes a aprofundar o estudo das tradições culturais do Povo Angolano;

d) Incentivar a criação literária dos seus membros, nomeadamente proporcionar-lhes condições favoráveis ao seu trabalho intelectual e à difusão das suas obras; e) Propiciar a revelação de novos escritores, orientando os seus esforços e dando-lhes o necessário apoio;

f) Promover congressos e reuniões de escritores e outras manifestações de carácter cultural com o fim de elevar o nível literário e artístico dos seus membros e do povo Angolano em geral;

g) Editar um boletim informativo em papel ou web e outras publicações;

h) Fortalecer os laços com a literatura e as artes dos outros Povos Africanos;

i) Incrementar as relações culturais com todos os Povos do mundo;

j) Desempenhar quaisquer atribuições que lhe sejam conferidas por lei;

2. Na defesa dos interesses dos membros da União dos Escritores Angolanos (UEA) compreende-se a dos seus direitos de autor, sob qualquer forma.

Dos Membros da União

Artigo $5^{\circ}$

1. Os membros da União dos Escritores Angolanos são:

a) Membros fundadores: Os escritores angolanos que tenham assinado a Proclamação da União dos Escritores Angolanos, no dia 10 de Dezembro de 1975;

b) Membros efectivos: os escritores angolanos que, não sendo fundadores, tenham produção literária publicada em livro;

c) Membros Associados: os autores estrangeiros que residam em Angola, assim como os que, residindo no estrangeiro, contribuam para o estudo, a divulgação e o prestígio da literatura angolana;

d) Membros Honorários: as personalidades, organismos ou entidades, públicas ou privadas, nacionais ou estrangeiras, que apoiem ou prestem serviços relevantes à União;

2. Os membros associados e honorários participam livremente nas actividades da União dos Escritores Angolanos, mas não podem ser eleitos para os órgãos sociais, nem têm direito a voto nas assembleias para as quais sejam eventualmente convidados.

Artigo $6^{\circ}$

1. A admissão será pedida por escrito pelo candidato que tenham publicado duas obras e proposta por três membros da União no pleno gozo dos seus direitos.

2. Compete à Comissão Directiva deliberar sobre a admissão do candidato, a qual deve ser decidida por maioria dos seus membros.

3. Da recusa de admissão podem os proponentes recorrer à Assembleia - geral no prazo de 15 dias a contar da data de recepção do aviso daquela recusa.

4. Compete à Assembleia - geral admitir os membros associados e honorários.

Dos Direitos e Deveres

Artigo $7^{\circ}$

1. Os membros da União são obrigados:

a) A assumir plenamente a sua condição de escritor, intervindo na vida cultural do País através da produção literária e da participação noutras actividades de carácter cultural; 
b) A respeitar os Estatutos e Regulamentos e a concorrer para o prestígio e progresso da União;

c) A desempenhar os cargos sociais para que forem eleitos;

d) A pagar pontualmente as quotas devidas;

e) A contribuir para a União com quatro exemplares de cada livro que publiquem fora das edições da União dos Escritores Angolanos (UEA).

Artigo $8^{\circ}$

1. Os membros da União têm direito:

a) A tomar parte ou fazerem-se representar nas Assembleias-gerais, com direito de voto, a ser eleitos para os cargos sociais e a fazer parte das comissões especiais;

b) A participar em todas as actividades organizadas pela União, de acordo com as modalidades e critérios estabelecidos pela Comissão Directiva, no âmbito das suas competências e atribuições;

c) A solicitar esclarecimentos e informações sobre todas as actividades da União dos Escritores Angolanos, para o que lhe será prestada toda a colaboração pela Comissão Directiva, bem como o acesso a toda a documentação necessária;

d) A usufruir todas a regalias que a União conceda aos seus membros.

Das Sanções

Artigo $9^{\circ}$ Os membros da União estão sujeitos as seguintes sanções:

a) Censura registada;

b) Suspensão de um a seis meses;

c) Demissão;

d) Expulsão;

Artigo $10^{\circ}$ A censura registada será aplicada ao membro que, pela primeira vez, e por suas palavras ou actos, ponha em causa os princípios da União ou cometa falta leve contra os Estatutos ou Regulamentos.

Artigo $11^{\circ}$

1. A pena de suspensão será aplicada ao membro que:

a) Reincida nas faltas previstas no artigo anterior;

b) Deva mais de seis quotas sem motivo justificado;

c) For negligente no exercício dos cargos sociais para que tenha sido eleito ou dos cargos que tenha aceitado desempenhar nas comissões especiais.

2. Para a falta mencionada na alínea

b) do número anterior, a suspensão não pode exceder três meses.

Artigo $12^{\circ}$ A pena de demissão será aplicada ao membro que deva mais de nove quotas sem motivo justificado.

Artigo $13^{\circ}$ A pena de expulsão será aplicada ao membro que:

a) Cometa de forma reiterada as faltas a que se referem os artigos $10^{\circ}$ e $11^{\circ}$;

b) Desprestigie ou lese gravemente a União por suas palavras ou actos;

c) Infrinja gravemente os Estatutos ou os Regulamentos.

Artigo $14^{\circ}$

1. A aplicação das penas das alíneas a), b) e c) do artigo $9^{\circ}$ compete à Comissão Directiva e a aplicação da pena do Artigo $12^{\circ}$, sobre a pena de demissão, compete à Assembleia-geral.

2. Das sanções impostas nos termos do $n^{\circ} 1$ do presente artigo, há recursos para a Assembleia-geral, a interpor pelo punido no prazo de 30 dias a contar da sua notificação. Artigo $15^{\circ} 1$. Passado um ano sobre a aplicação definitiva das penas de demissão ou expulsão, o membro punido poderá ser readmitido pela Assembleia-geral se a sua conduta o justificar e o seu pedido de readmissão for proposto pelo menos por quatro dos membros da União no pleno gozo dos seus direitos. 2. A decisão da Assembleia-geral que apreciar recurso de pena de expulsão só poderá ser tomada por um mínimo de dois terços dos membros da União dos Escritores Angolanos.

Dos Corpos Gerentes

Artigo $16^{\circ}$ Os corpos gerentes da União dos Escritores Angolanos (UEA) são a Mesa de Assembleiageral, a Comissão Directiva e o Conselho Fiscal.

Secção II Da Mesa da Assembleia-geral

Artigo $17^{\circ}$

1. A Mesa da Assembleia-geral é constituída por um Presidente, um Vice-Presidente e um Secretário.

2. O Vice-Presidente substituirá o Presidente nas suas faltas ou impedimentos, na falta ou impedimentos de ambos, serão substituídos por um Presidente eleito (ad-hoc) pela Assembleia-geral mas sob proposta do Secretário-geral. Artigo $18^{\circ}$ É da competência do Presidente:

a) Convocar a Assembleia-geral e dirigir os seus trabalhos;

b) Dar posse aos corpos gerentes eleitos pela Assembleia-geral, nos oito dias seguintes à eleição;

c) Exercer as atribuições que lhe sejam conferidas pelo regulamento eleitoral ou outros regulamentos aprovados pela Assembleia-geral. 
Artigo $19^{\circ}$ Ao Secretário compete redigir as actas e promover todo o expediente da Mesa.

Artigo $20^{\circ}$ São atribuições da Assembleia-geral:

a) Interpretar os Estatutos e alterá-los;

b) Aprovar o regulamento eleitoral, bem como quaisquer outros que se mostrem necessários para o bom funcionamento da União e dos seus serviços;

c) Fixar a remuneração do Secretário-geral;

d) Discutir e aprovar as contas de gerência;

e) Decidir os recursos interpostos das sanções aplicadas pela Comissão Directiva; f) Expulsar membros e readmiti-los;

g) Deliberar soberanamente sobre todos e quaisquer assuntos respeitantes à União, com respeito da Lei e dos Estatutos;

h) Fixar a quota e outras prestações a que os membros da União dos Escritores deverão livremente obrigar-se.

Artigo $21^{\circ}$

1. As Assembleias-gerais são ordinárias e extraordinárias.

2. Haverá uma Assembleia-geral ordinária, trienalmente, no quadragésimo dia que antecede a data de cessação do mandato dos corpos gerentes, para apreciação do relatório e contas da Comissão Directiva cessante e marcação do pleito eleitoral para o triénio seguinte, bem como para a fixação da remuneração do Secretário-geral.

3. A Assembleia-geral reunirá extraordinariamente:

a) Sempre que a Comissão Directiva o julgar necessário;

b) Para julgamento dos recursos interpostos de recusa de admissão de membros da União;

c) Para julgamento dos recursos interpostos de sanções aplicadas pela Comissão Directiva;

d) Para readmissão de membros expulsos;

e) Quando um mínimo de 15 membros da União no pleno gozo dos seus direitos o requeira, por escrito, ao presidente da Mesa, com a indicação precisa dos assuntos a tratar.

Artigo $22^{\circ}$ Eleições

1. As eleições fazem-se por sufrágio universal, directo e com voto secreto, exercido presencialmente ou por procuração por parte dos escritores ausentes.

2. São eleitores e podem ser eleitos para os órgãos da UEA, os escritores membros efectivos com inscrição em vigor, que não se encontrem em qualquer situação de impedimento.

3. Sem juízo do disposto no número anterior, só podem ser eleitos para Presidente da Assembleia-geral e Secretário-geral os escritores que possuam, respectivamente, pelo menos 15 e 10 anos de vínculo à Instituição.

4. O exercício de cargos dirigentes em outras ou associações é incompatível com a titularidade de quaisquer órgãos da UEA.

Artigo $23^{\circ}$ Mandatos

1. Os titulares e membros dos órgãos da UEA são eleitos para mandatos com a duração de três anos, a iniciar em 1 Janeiro e terminar em 15 de Dezembro.

2. Os titulares e membros dos órgãos da UEA podem ser eleitos por mais de dois mandatos consecutivos para cada um dos lugares de Direcção.

Artigo $24^{\circ}$ Convocatórias

1. A Assembleia-geral será convocada pelo Presidente da Mesa com quinze dias de antecedência, pelo menos, por meio de aviso tornado público através dos meios de comunicação social e no qual se indique a ordem de trabalho, o dia, a hora e o local da reunião.

2. Nas Assembleias-gerais ordinárias poderão ser tomadas deliberações diversas das indicadas no $\mathrm{n}^{\circ} 2$ do artigo $21^{\circ}$ desde que os assuntos a que respeitam constem da ordem de trabalho.

3. Nos casos do $n^{\circ} 3$ do artigo anterior, a convocação da Assembleia-geral deve ser feita até dez dias depois da recepção do pedido respectivo.

Artigo $25^{\circ}$

1. A Assembleia-geral considera-se legalmente constituída com a presença ou representação, de pelo menos, um terço dos membros da União no pleno gozo dos seus direitos, não podendo o número de presenças ser inferior a dez.

2. Se a hora marcada no aviso convocatório não estiver presente ou representado um terço dos membros da União, a Assembleia funcionará meia hora depois, em segunda convocatória, com a presença de um mínimo de dez membros da União no pleno gozo dos seus direitos.

3. Cada membro não poderá representar mais de um membro ausente, mediante procuração, carta ou meio aceite como válido pela própria Assembleia.

4. Nos casos das alíneas b), d) e e) do artigo $21^{\circ}$, a Assembleia-geral não poderá funcionar se não estiverem pessoalmente presentes pelo menos dois terços dos membros que a requereram. 
Secção III Da Comissão Directiva

Artigo $26^{\circ}$ A Comissão Directiva da União será constituída pelo Secretário-geral, pelo Secretário Administrativo, pelo Secretário das Actividades Culturais e pelo Secretário das Relações Exteriores.

Artigo $27^{\circ}$

1. Compete à Comissão Directiva:

a) Representar e administrar a União e executar as deliberações da Assembleia-geral; b) Zelar pelo cumprimento dos Estatutos e Regulamentos;

c) Instalar Delegações da União ou constituir Comissões Provinciais ou Regionais onde e quando as circunstâncias o permitam, elaborando os respeitos regulamentos; d) Admitir membros efectivos da União,

e) Aplicar as sanções das alíneas a), b) e c) do artigo $9^{\circ}$

f) Readmitir membros efectivos da União;

g) Prestar contas da sua gerência; h) Requerer a realização de Assembleias-gerais extraordinárias ou a inclusão de assuntos extraordinários na ordem de trabalho das Assembleias ordinárias;

2. A Comissão Directiva reunirá normalmente duas vezes por mês e sempre que a convoquem, o Secretário-geral ou a maioria dos seus membros.

3. Só podem realizar-se as reuniões da Comissão Directiva quando esteja presente a maioria dos seus membros.

4. As deliberações serão tomadas por maioria dos presentes e com a presença do secretário a que o assunto diga respeito ou, na sua ausência, desde que previamente informado por ele.

Artigo $28^{\circ} 1$. Compete ao Secretário-geral da União:

a) Representar a Comissão Directiva da União;

b) Obrigar a União com a sua assinatura, juntamente com a do seu secretário-geral;

c) Assinar, quando necessário, a correspondência da União;

d) Delegar no Secretário-geral, por escrito, a totalidade ou parte dos poderes constantes das alíneas anteriores:

e) Presidir às reuniões da Comissão Directiva;

f) Dirigir as publicações periódicas da União;

g) Exercer quaisquer outras atribuições que lhe sejam conferidas pela Comissão Directiva;

h) Preparar todos os assuntos para apreciação da Comissão Directiva;

i) Dirigir o movimento editorial da União;

j) Assinar a correspondência corrente da União, salvo no caso de impossibilidade temporária, em que tal atribuição competirá a um dos secretários, por delegações do Secretário-geral;

k) Supervisar todos os serviços e actividades da União, em colaboração com os outros secretários;

1) Supervisar as actividades das Comissões Especiais;

m) Exercer quaisquer outras atribuições que lhe sejam conferidas pela Comissão Directiva;

2. O Secretário-geral exercerá as suas funções em permanência, recebendo a remuneração fixada pela Assembleia-geral que anteceda o pleito eleitoral.

Artigo $29^{\circ}$ Compete ao Secretário Administrativo da União:

a) Preparar todos os assuntos de carácter administrativo e financeiro da União para serem apresentados pelo secretário-geral à Comissão Directiva;

b) Dirigir os serviços administrativos e de contabilidade da União;

c) Exercer quaisquer outras atribuições que lhe sejam conferidas pela Comissão Directiva;

Artigo $30^{\circ}$ Compete ao Secretário de Actividades Culturais da União:

a) Preparar todos os assuntos respeitantes às actividades culturais da União para serem apresentados pelo secretário-geral à Comissão Directiva;

b) Promover e incrementar as relações com as organizações similares da União Existentes no mundo;

c) Fomentar a propaganda da União, de modo a torná-la conhecida e às actividades; d) Exercer quaisquer outras atribuições que lhe sejam conferidas pela Comissão directiva;

Artigo $31^{\circ}$ Compete ao Secretário das Relações Exteriores da União:

a) Preparar todos os assuntos respeitantes às relações exteriores da União para serem apresentados pelo secretário-geral à Comissão Directiva;

b) Promover e incrementar as relações com as organizações similares da União existentes no mundo;

c) Fomentar a propaganda da União, de modo a torná-la conhecida e às actividades; d) Exercer quaisquer outras atribuições que lhe sejam conferidas pela Comissão Directiva.

$32^{\circ}$ Serão resolvidas pela Comissão Directiva as divergências que possam surgir entre o secretário-geral e cada um dos outros secretários quanto aos factos e actividades que cabem na respectiva esfera de competência.

Secção IV Do Conselho Fiscal 
Artigo $33^{\circ} \mathrm{O}$ Conselho Fiscal é o órgão de fiscalização e controlo da União dos Escritores Angolanos e é composto por:

a) Presidente;

b) Secretário;

c) Relator;

Artigo $34^{\circ}$ Compete ao Conselho Fiscal:

a) Exercer a fiscalização das contas, com a colaboração do secretário administrativo; b) Dar parecer sobre o relatório e contas da Comissão Directiva e das delegações ou comissões provinciais ou regionais;

c) Dar parecer prévio sobre aceitação de doações, heranças ou legados;

d) Dar parecer sobre qualquer assunto de natureza patrimonial da União dos Escritores Angolanos, sempre que solicito pela Comissão Directiva ou determinado pela Assembleia-geral;

e) Assistir às reuniões da Comissão Directiva, sempre que, para o cabal cumprimento das suas funções, achar isso necessário;

f) Exercer quaisquer outras actividades que lhe sejam atribuídas pela Assembleia-geral.

Artigo $35^{\circ} \mathrm{O}$ Conselho Fiscal reúne ordinariamente uma vez por semestre e extraordinariamente sempre que for convocado pelo seu presidente, por sua iniciativa, a pedido de qualquer associado ou da Comissão Directiva, sendo as suas deliberações tomadas por maioria de votos dos seus membros.

Artigo $36^{\circ}$

1. Ao Presidente do Conselho Fiscal compete convocar e presidir à reuniões e representar o Conselho Fiscal;

2. Ao Secretário do Conselho Fiscal compete tratar de todas as questões relativas ao expediente e elaborar as actas das reuniões;

3. Ao Relator do Conselho Fiscal compete redigir os pareceres do Conselho Fiscal e exercer quaisquer outras funções que por este lhe tenham sido confiadas. Funcionários e Colaboradores

Artigo $37^{\circ}$

1. Para a prossecução dos seus objectivos, a União dos Escritores Angolanos fará recurso à contratação de funcionários e colaboradores.

2. São funcionários os membros e não membros da União dos Escritores Angolanos que desenvolvam profissionalmente a sua actividade na entidade, em regime de permanência, recebendo remuneração compatível, constituída por um salário e um subsídio, nomeadamente o Secretário-geral e os funcionários admitidos para os órgãos internos da União.

3. São Colaboradores os membros e não membros da União que prestem colaboração eventual ou permanente à entidade ou a qualquer um dos seus projectos e actividades, podendo receber uma avença, nomeadamente os membros da Mesa da Assembleia-geral e do Conselho Fiscal, o Presidente da Comissão Directiva, os Secretários e outros.

4. As relações laborais entre a União e os funcionários e colaboradores deverão ser regidas mediante contrato escrito.

5. É da competência da Comissão Directiva a contratação e desvinculação de funcionários e colaboradores, excepto quando se tratar de membros dos órgãos sociais da União dos Escritores Angolanos;

6. Os salários, subsídios e avenças a pagar aos funcionários e colaboradores serão fixados pela Comissão Directiva, salvo o disposto na alínea c) do artigo $20^{\circ}$ dos presentes Estatutos.

Fundos

Artigo $38^{\circ}$

1. Constituem fundos da União dos Escritores Angolanos:

a) $\mathrm{O}$ produto das quotas e demais prestações a que os membros se obriguem;

b) Os rendimentos de bens próprios;

c) As doações, legados, heranças e respectivos rendimentos;

d) Os subsídios, donativos, comparticipações, patrocínios e financeiros de que seja beneficiária;

e) O produto de subscrições e das suas actividades;

f) Outras receitas;

g) O orçamento anual é aprovado pela Assembleia-geral.

Do Fundo Social

Artigo $39^{\circ}$ Subsídios e pensões bem como outras regalias de carácter social em benefício dos membros da União dos Escritores Angolanos, serão definidos em regulamento.

Das Comissões Especiais

Artigo $40^{\circ}$ 
1. Para a realização de tarefas específicas, pode a Comissão Directiva criar Comissões Especiais e nomear os membros da União que hão-de constitui-las.

2. Cada Comissão Especial será coordenada pela Comissão Directiva ou por qualquer dos seus membros, sendo as suas actividades supervisionadas pelo secretário-geral. 3. Sempre que necessário, a Comissão Directiva elaborará as normas regulamentares das Comissões Especiais.

4. Os membros de cada Comissão Especial cessarão as suas funções juntamente com a Comissão Directiva que os houver nomeado.

Da Alteração dos Estatutos, da Dissolução E da Liquidação da União

Artigo $41^{\circ}$ Os Estatutos da União só podem ser alterados em Assembleia-geral, convocada expressamente para o efeito e as alterações carecerão de homologação do Governo da República de Angola.

Artigo $42^{\circ}$ A União só pode dissolver-se mediante deliberação da Assembleia-geral, convocada expressamente para o efeito.

Artigo $43^{\circ}$

1. As Assembleias-gerais extraordinárias para alteração dos Estatutos ou para dissolução da União não poderão funcionar sem presente ou representada metade, pelo menos, dos membros da União no pleno gozo dos seus direitos.

2. A Assembleia-geral para alteração dos Estatutos poderá funcionar em segunda convocatória feita com a antecedência mínima de dez dias com qualquer número de membros da União no pleno gozo dos seus direitos.

Artigo $44^{\circ}$ A Assembleia-geral que deliberar a dissolução da União nomeará uma Comissão Liquidatária, composta de cinco membros, a qual procederá à liquidação e dará destino aos bens da União conforme determinado pelo Governo da República de Angola.

Das Insígnias

Artigo $45^{\circ}$

1. A União dos Escritores Angolanos terá um emblema, uma sigla e uma bandeira aprovados pela Assembleia-geral.

2. As cores da União dos Escritores Angolanos são o azul, branco e preto.

Disposições Finais

Artigo $46^{\circ}$ A União dos Escritores Angolanos reger-se-á pela lei das Associações, pelos presentes Estatutos e pelos seus regulamentos internos.

Artigo $47^{\circ}$ As dúvidas que existirem na interpretação e aplicação dos presentes Estatutos, bem como as suas omissões, serão resolvidas pela Assembleia-geral. 
Anexo E - Capa do livro de leituras utilizado para o Ensino de Base $-2^{\circ}$ nível na República Popular de Angola em 1983

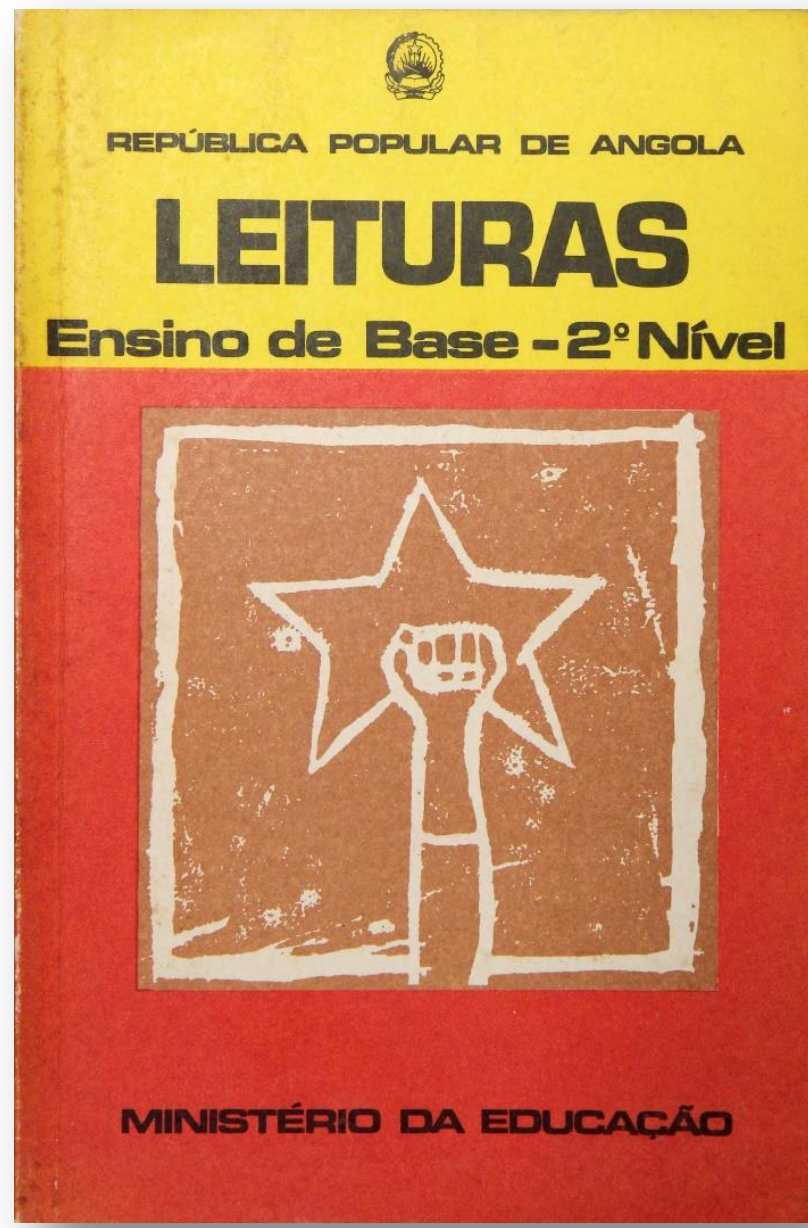


Anexo F - Contracapa do livro de leituras utilizado para o Ensino de Base $-2^{\circ}$ nível na República Popular de Angola em 1983

\section{ESTUDAR É UM DEVER REVOLUCIONÁRIO}


Anexo G - Capa e ficha catalográfica do livro Manguxi da Nossa Esperança, editado pela União dos Escritores Angolanos

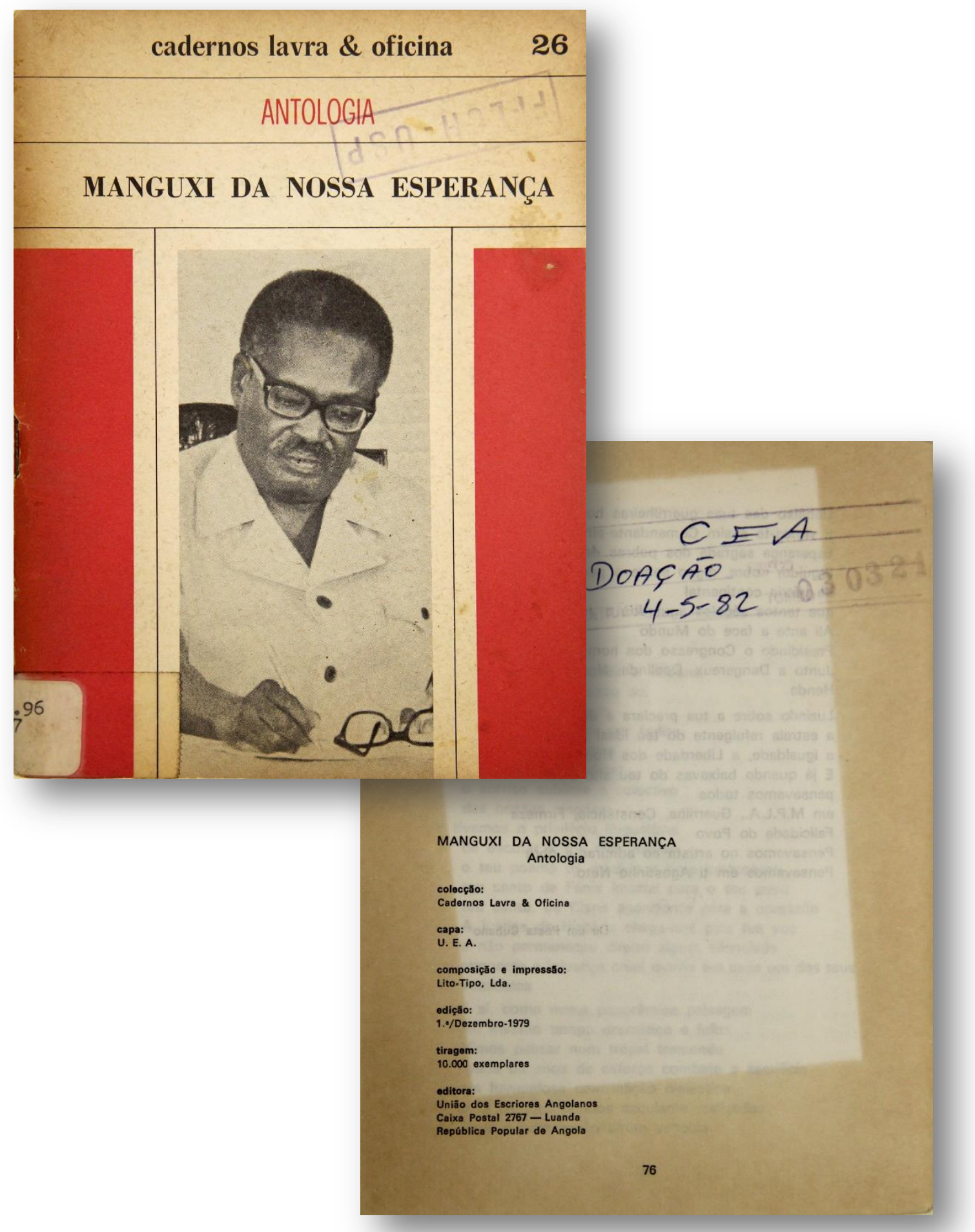


Anexo $\mathrm{H}$ - Capa e ficha catalográfica do livro Estórias do cágado, editado pela União dos Escritores Angolanos

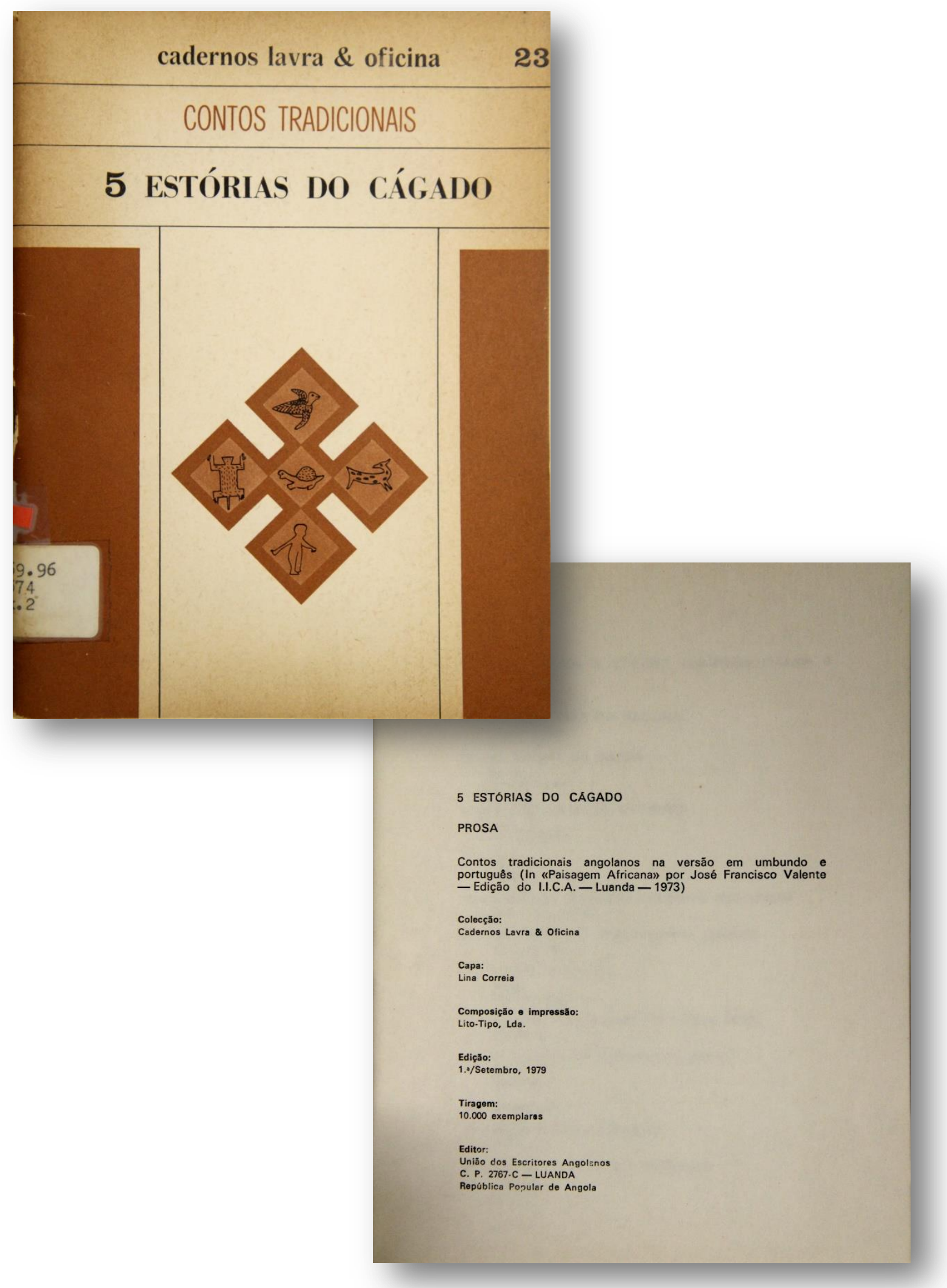


Anexo I - Capa e ficha catalográfica do livro 11 poemas em novembro, editado pela União dos Escritores Angolanos

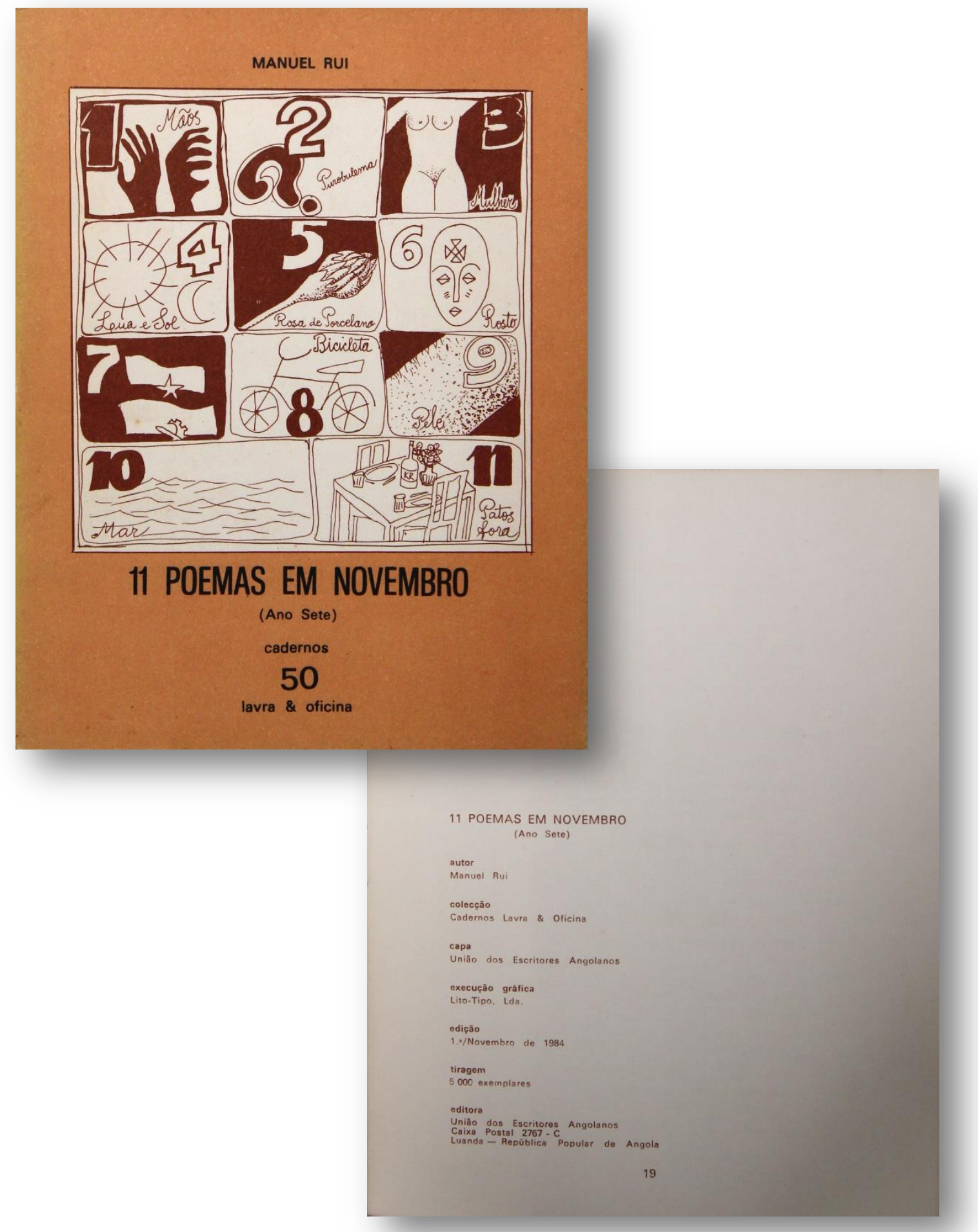


Anexo J - Capa e ficha catalográfica do livro No país da brincaria, editado pela União dos Escritores Angolanos

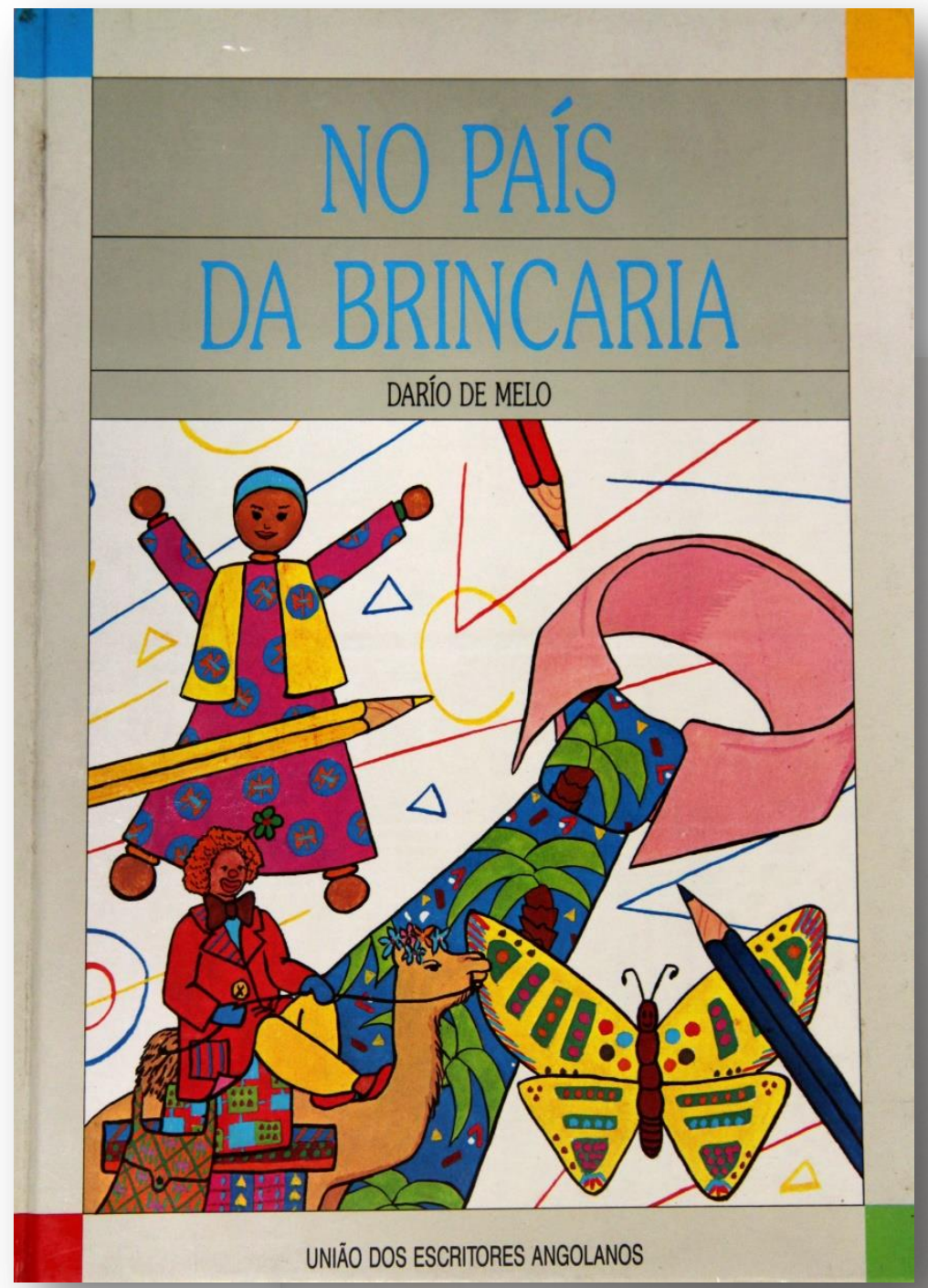

Execução Gráfica

EDIC̣ŌES ASA-Divisão Gráfic

PTiteg 9716610 Rua D. Afonso Henriques, 742 / 4435 RIO TINTO / PORTUGAL 1988-20 000 Exemplares 
Anexo L - Capa do livro Projecto Comum, da Coleção Lavra \& Oficina da União dos Escritores Angolanos, cujas dimensões são $14 \mathrm{~cm}$ x $18 \mathrm{~cm}$
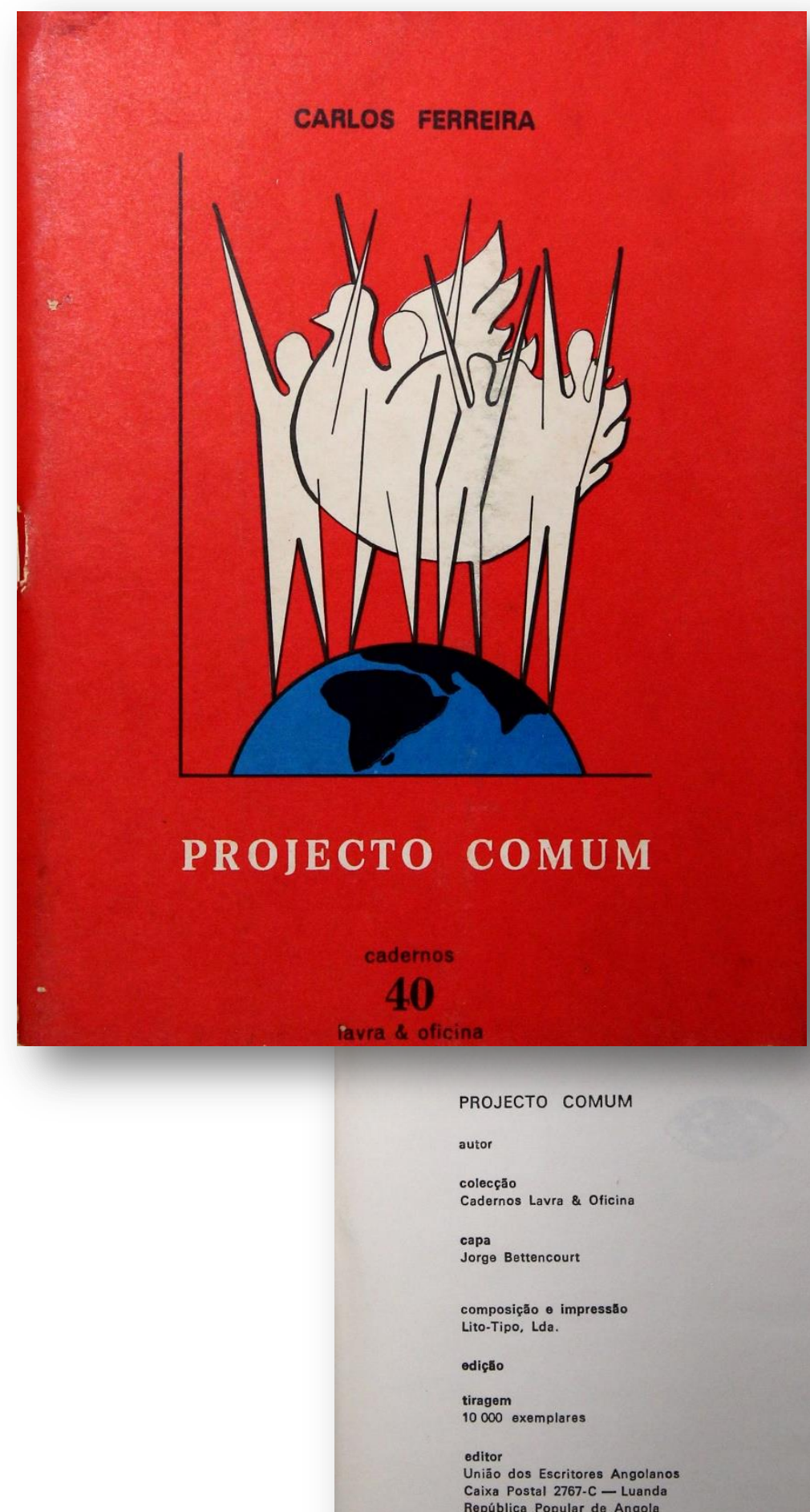

República Popular de Angole 
Anexo M - Coleção de capas do boletim Gazeta Lavra \& Oficina publicadas entre 1979 e 1985 pela União dos Escritores Angolanos

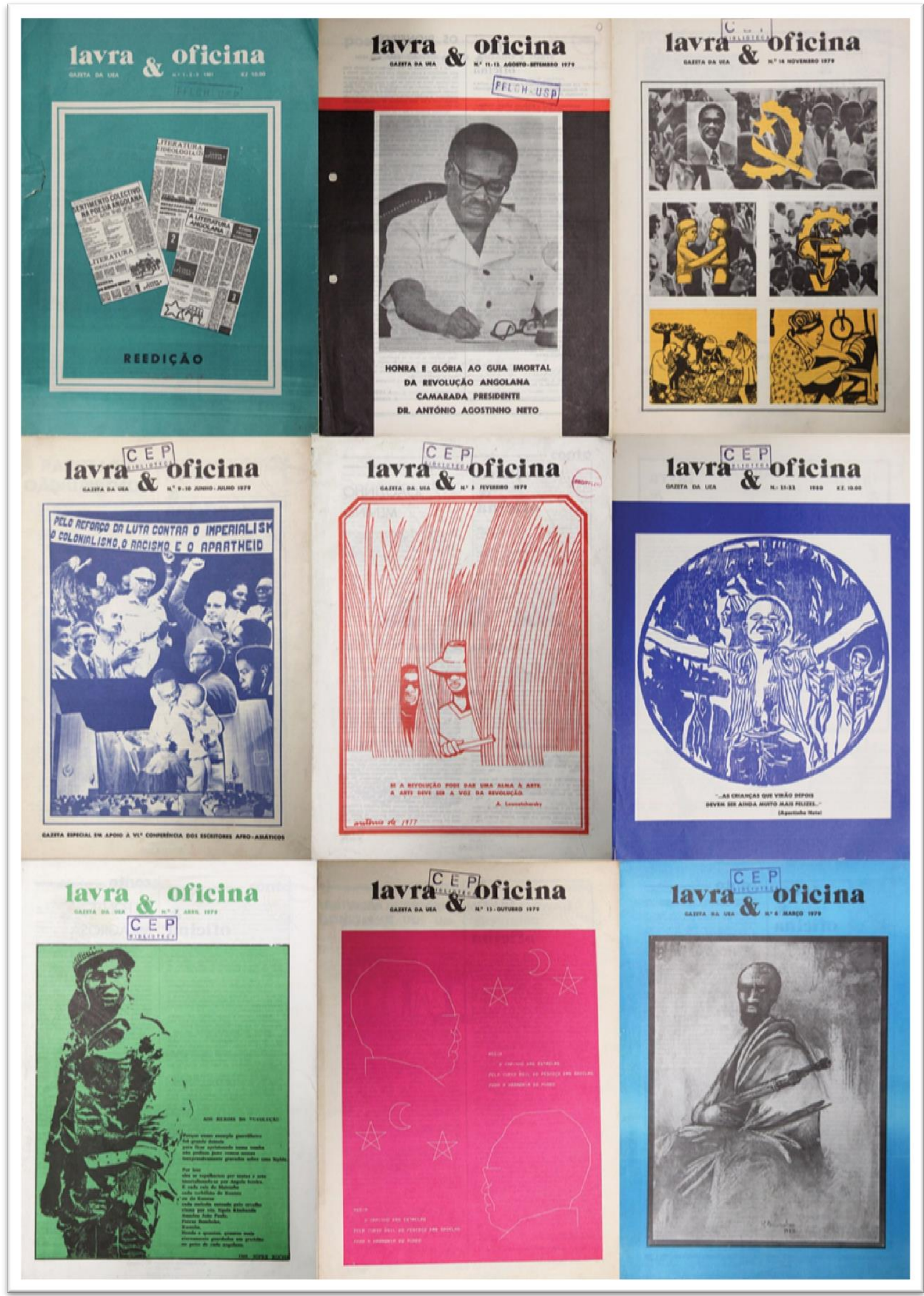




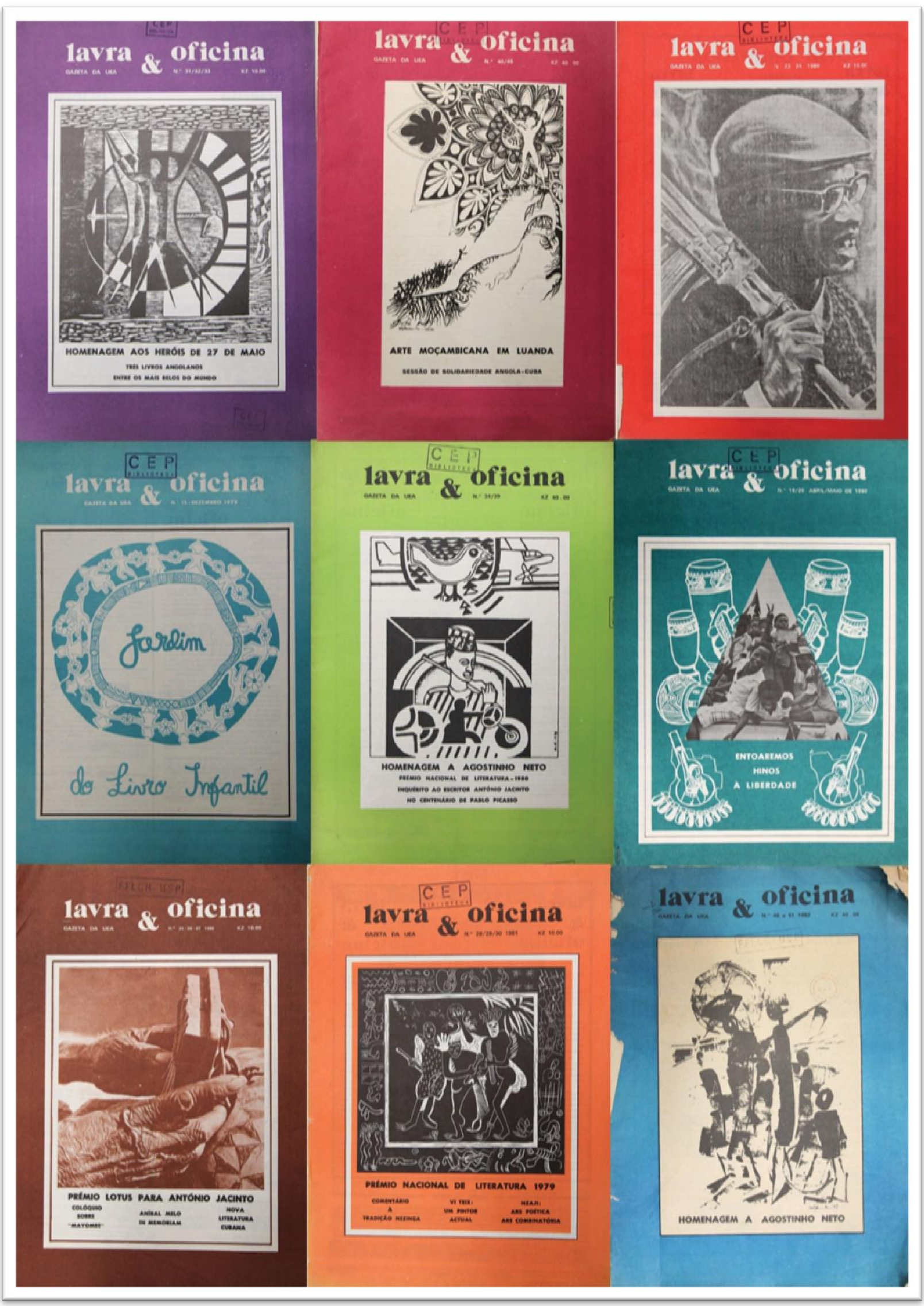




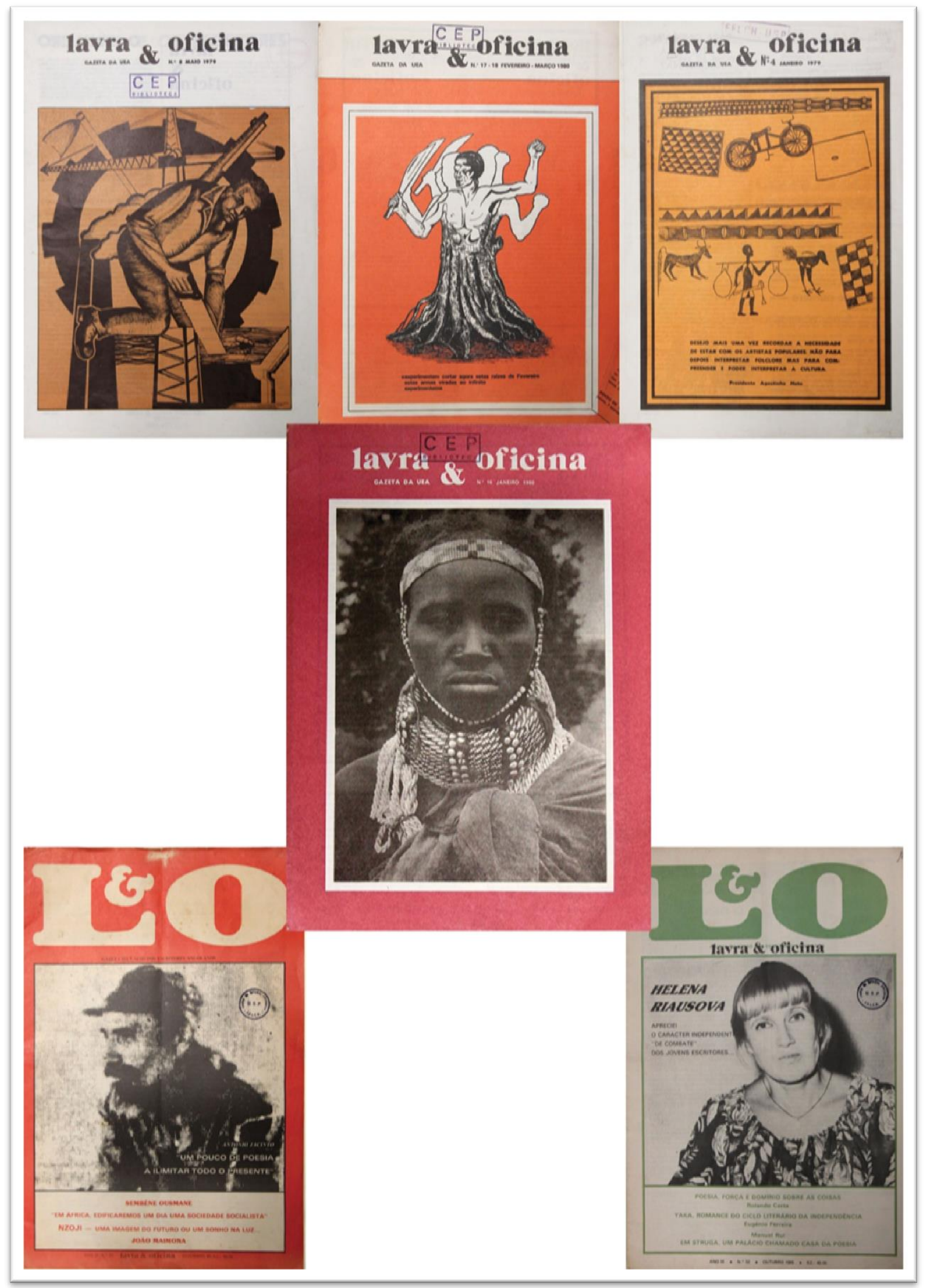


Anexo N - Imagem de Agostinho Neto presente em livros infantis publicados pela União dos Escritores Angolanos 
Anexo O - Capa de livro de banda desenhada publicado pela União os Escritores Angolanos que tem Masala como protagonista

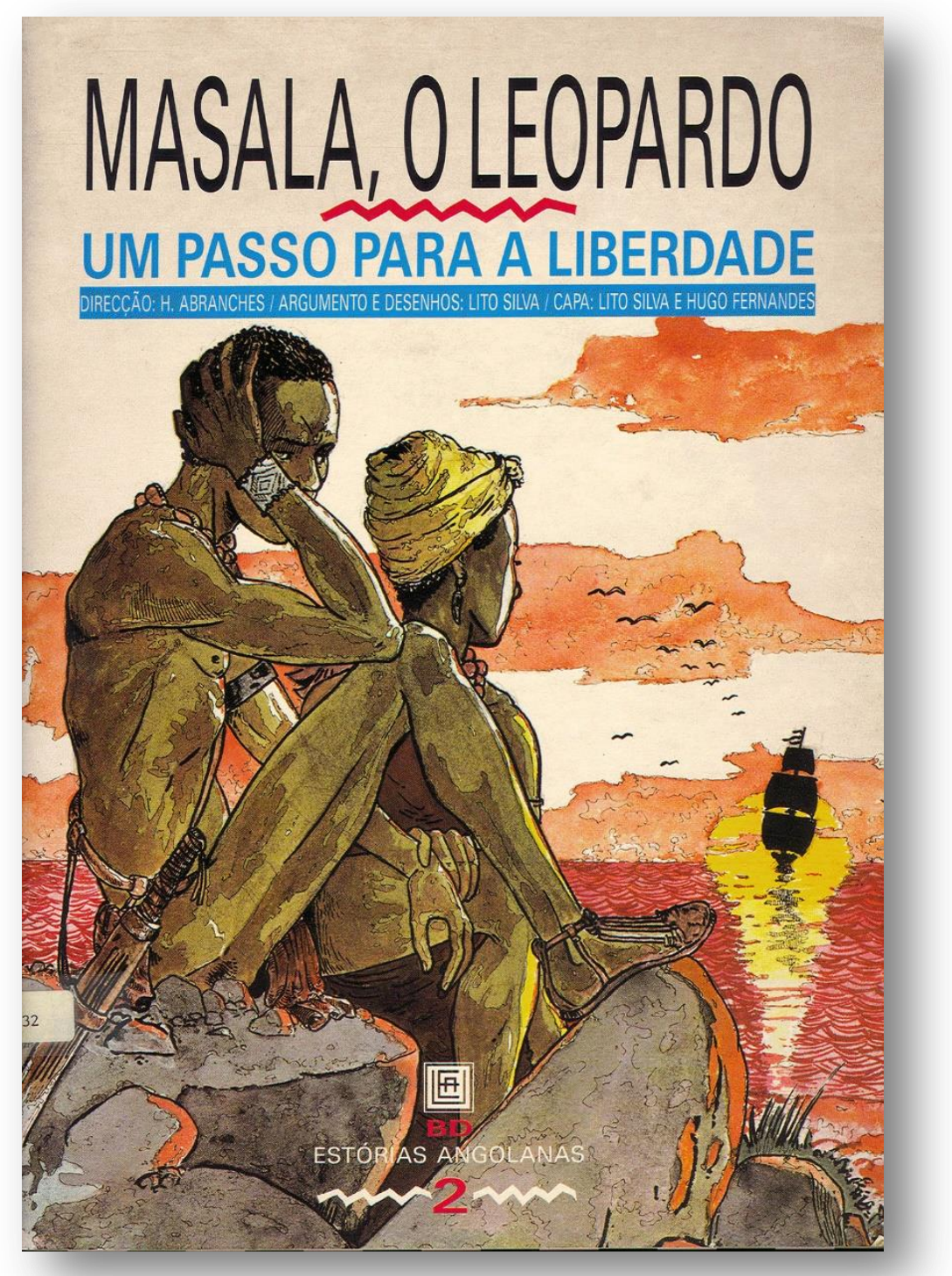


Anexo P - Matéria sobre a União dos Escritores Angolanos publicada no jornal norteamericano The New York Times de 03 de janeiro de 1985

\section{ANGOLAN WRITERS BLOOM IN INDEPENDENT CLIMATE}

By JAMES BROOKE

Published: January 3, 1985

LUANDA, Angola - When the Soviet Union celebrated the 5oth anniversary of Socialist Realism last year, its most orthodox ally in Africa was marching to a different drummer on the subject of writers and writing.

With relative freedom to write and Government help to publish, writers in Marxist Angola have emerged to form a major current in African literature. Despite a national illiteracy rate of 80 percent, literature is now Angola's richest art form.

A foundation for this growth was set in 1977, two years after Angola's independence from Portugal, when Agostinho Neto, the country's first president and a poet, broke with Soviet prescriptions for literature.

"We should not fall into fixed patterns or stereotypes like those of the socialistrealist theorists," Dr. Neto, a physician, said in a speech before the Angolan Writers Union. "Time cannot be taken up with accommodations to imported themes and forms."

'Flowers Like Rocks'

A Marxist, Dr. Neto visited the Soviet Union several times, and brought home an East-bloc political model for his new nation. But Dr. Neto was also a gifted and sensitive poet. In a fit of exasperation, he once lectured a group of foreign correspondents that they made "flowers look like rocks."

On literature, Dr. Neto broke with Soviet orthodoxy. He urged Angolan writers to "go beyond class" and to "understand the people just as they are defined."

"To caricature the petty bourgeoisie, or to describe it, is as valid as exalting the peasant or the worker," he said.

With Government help, the publication of Angolan writers exploded. In 1976, the first year of independence, the total printing amounted to 1,500 copies of all new books by the nation's authors. By 1979, the annual printing had reached 500,ooo. 
'Kept in the Drawer'

"During the first years, we printed everything that was kept in the drawer due to colonial silence," said Luandino Vieira, a prominent novelist who became general secretary of the Angolan Writers Union after Mr. Neto's death in 1979.

In an apparent paradox, the majority of Angola's population of seven million is illiterate, but books by Angolan authors regularly sell out. As a partial explanation, Mr. Vieira told of an illiterate worker who carefully collected an entire series of Angolan writers in the hope that his children would read him the stories.

Mr. Vieira, who spent 11 years in Portuguese colonial prisons, has maintained Dr. Neto's tolerant approach toward writers, their themes and their styles.

"We want to allow all tendencies to flower - symbolist, surrealist, concretist," he said in an interview. "The function of a novelist is not to be a critic nor an apologist for Government."

In contrast, Konstantin U. Chernenko, the Soviet leader, in a speech marking the 50th anniversary of the Soviet Writers Union last September, reaffirmed Socialist Realism as "the chief artistic method of our literature and art."

'Girl Meets Tractor'

This orthodox Marxist style presents a cheery picture of life under Socialism. In the West, it has sometimes been parodied as the "girl- meets-tractor" school of writing.

When asked about Socialist Realism, Mr. Vieira replied: "A positive hero is only one aspect of the very complex human character."

For English-speaking readers, there are now translations from Portuguese of novels by Mr. Vieira and by Artur Pestana, who writes under his old nom de guerre, Pepetela, and of an anthology of Angolan poetry. Written with an ear for language and an eye for detail, these works give a foreign reader a rare insight into African society, a world that is generally impenetrable to the casual visitor.

Written in the African storytelling tradition, Mr. Vieira's novels "Luuanda" and "The Real Life of Domingos Xavier" lead the reader down the dirt paths, into the shacks and into the minds of the dwellers of Luanda's "musseques." As in many African cities, Luanda, Angola's capital, is divided into a belt of African shantytowns, called "musseques," which surrounds a largely European core, known 
here as "the asphalt city." Mr. Vieira, the son of a Portuguese shoemaker, grew up in Luanda's "musseques."

In this passage from "Luuanda" he describes a thunderstorm breaking over a shantytown: "When the first big thunderclap burst above the musseque, shivering the weak walls of mud and wattle and loosening boards, cardboards and straw mats, everyone closed their eyes, frightened by the blue brilliance of the lightning born in the sky, a great spider web of fire."

Behind Political Slogans

The Angolan novels reach behind a facade of political slogans and explore the workaday lives of the Angolan common man and woman, their motivations, their world view, their racial and sexual relations. In "Domingos" an African woman gives advice to a friend searching for her husband imprisoned by colonial authorities: "My son said you should go to the Authority to make inquiries, to make a fuss, to weep. Don't leave without finding out where Domingos is. The best thing is to take Batsy and make the kid bellow!"

According to Artur Pestana, whose war novel, "Mayombe," was published in English late last year by Heinemann Books, "If Americans were to read our poetry and novels they would have a less dogmatic and stereotyped vision of us."

Angolan poetry, much of it written by guerrillas during the war for independence, weds a sensitivity of language to themes that preoccupy Angolans - war, exile and colonial exploitation. Although the Government allows independent points of view from its poets and authors, most writers are still riveted by the events of the country's colonial past and revolutionary struggle.

Ngudia Wendel, a guerrilla commander sent to study in Italy and the Soviet Union, wrote nostalgically of his native land in "We Shall Return, Luanda": Luanda, you are like a white sea

gull on the ocean crest - bright streets under the white sun, flight of green palm trees...

Joao Abel, a bank worker, wrote of a Luanda newspaper vendor in "Black Joao": Stock still in a corner staring at the letters printed in black in the huge newspaper he cannot understand.

Costa Andrade, who spent several years in Portuguese prisons, wrote "Essay on Color" while serving as a guerrilla fighter in Eastern Angola: Those who discuss the 
dimension of bright red and write treatises on the function of color never saw the red of a wound opened by the burst of a grenade...

War is never far from thoughts here. During the course of the interview with Mr. Vieira at the Writers Union, a brace of MIG fighter jets screamed overhead, Army trucks from a nearby garrison rumbled by and a wounded soldier could be seen swinging on crutches across a nearby field. In Angola's nine years of independence, South Africa has invaded 12 times and the central Government seems permanently tied down in a war against South African-supplied guerillas.

War-induced bottlenecks and a paper shortage have touched the world of literature and caused the total number of books printed in 1983 to fall to 150,000 copies.

However, Mr. Vieira is aiming to restore production in 1985 to the level of 500,000 copies. He has formed groups of young writers in four Angolan cities, and every Wednesday afternoon writers and intellectuals gather under a large poster of Agostinho Neto in a conference hall here for free-wheeling debates, called "makas."

In an interview conducted earlier in the United States, Russell G. Hamilton, the author of two books on the literature of Portuguese-speaking Africa, attributed the open-mindedness of Angola's Marxists toward literature to Dr. Neto's policy speech shortly after independence.

"Even in that atmosphere of revolutionary fervor, many of them were waiting for Neto to make that condemnation of Socialist Realism," said Professor Hamilton, dean of graduate studies at Vanderbilt University. "There was a collective sigh of relief when it happened." 
Anexo Q - Regulamento do Prêmio Nacional de Cultura, iniciativa da União dos Escritores Angolanos

\section{- COMBOIO ELÉCTRICO UM CONTO DE HÉLDER NETO}

Era uma tarde quente, sem vento. Sobre o asfalto uma onda de vapor, ondulante, continua, que se estendia ate

As árvores quietas. A rua deserta. Um silêncio sonolento De rese pelo ar.

De repente, as árvores mexeram-se espantadas, a onda rasteira de vapor ondulou ainda mais, protestando, e o sol que the obrigassem a parar aquele menino que vinha correndo pelo asfalto.

Corrida louca. Na cara estampava-se o esforço e o medo. Os pés disformes não sentiam o calor abrasante do asfalto Debaixo da camisa suja e rota arquejava um peito feito de

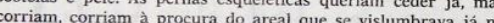
fim do asfalto.

Os braços, encostados ao peito, levavam o roubo. O roub feito na loja. E o menino corria e o areal parecia cada ve mais longe. Olhava constantemente para trás. As pernas tropeçavam mas conseguiam equilibrar-se sempre. Corria, olhava, correndo quanto tho permitiou als pernas o homem da loja os sapatos grossos atrapalhando a corrida para apanhar adrāo.

Se o deixasse chegar ao areal era certo. Nunca mais veria. E tornaria a roubar noutras lojas, pois na dele, nunce Cosgraçado dele se entrasse lá.

Corria o menino, corria o homem. $\mathrm{O}$ areal cada vez mais to do areal. mem apelou para a sua ira - não era bem por causa do roubo, mas pelo castigo que se tem de dar-para the dar o alento necessario.

-Ah, que se me escapa! Agarra, agarra, que é ladrāo Agarra, agarra, que é ladrāo!

Duas cabeças infantis surgiram no muro duma casa. Muro baixo, separando o passeio do jardim. Algumas janelas se para ver o motivo da algazarra do hamem, curiosidade e raiva do sono da tarde. Os meninos que brincavam no jardim ficara sérios vendo o rapaz que vinha correndo e o homem, mais 1 atrás.

E o menino olhou os outros meninos. E viu o jardim, tambem. Na relva, um comboio que andava solno, na linh túneis. Parava, voltava atrás e seguia outra vez.

Os olhos ficaram presos no brinquedo nunca visto. A pernas esqueceram-se de correr e lentamente foram-se acercando do jardim. Um sorriso largo se abriu no rosto magro.

Os outros meninos olharam o ladrăo.

- Mamá, olha este rapaz-choraram.

E comboio subia e descia.

A mamar filhos.

E o homem que vinha correndo chegou, bufando, os olhos

brilhantes por apanhar $\mathrm{o}$ ladrão.

E o comboio passava por pontes, parava, voltava atrás e prosseguia.

As pancadas caíram no corpo esquelético do menino. A mas encolhe os ombros e voltou para continuar a sesta e os meninos, que estavam
sivelmente redobraram o choro.

No rosto do menino-ladräo estampou-se um enorme espanto.

E o comboio continuava a andar sozinho, subindo e des. cendo, passando pontes e túneis, parando, voltando atrás e prosseguindo. (IN CULTURA N: 6/7 MARÇO, 1959)

\section{PRÉMIO NACIONAL}

\section{DE LITERATURA}

1. A Uniāo dos Escritores Angolanos institui um pré mio anual destinado a galardoar o melhor livro de po ficçāo ou ensaistica de autor angolano, publicado na Republica Popular de Angola no período compreendido entre seguinte, denominado PREMIO NACIONAL DE do ano TURA.

2. O PREMIO NACIONAL DE LITERATURA, para além do simbolismo da distinção, consiste na importância

3. O PREMIO NACIONAL DE LITERATURA é solenemente entregue no dia 10 de Dezembro, data da procla

4." O Júri ao qual compete a apreciaçāo das obras e a atribuição do PRÉmio NACIONAL. DE LITERATURA são composto por trectiva da Uniāo dos Escritores Angados pela Comismento designado pela Secretaria de Estalo da Cum ele um outro designado pelo Departamento de Cultura e Desportos do M.P.L.A. - Partido do Trabalho.

Parágrafo único Os membros escolhidos para o júri por dois anos consecutivos.

5. Serāo considerados pelo júri os livros de que a Uniáo dos Escritores Angolanos tenha recebido dois exem MIO NACIONAL DE

Parágrafo único Exceptuam-se do disposto do corpo to artigo os livios 6.: O júri é livre de não atribuir o PREMIO-NACIO ITERATURA e das suas decisões não cabe recurso.

7 Os casos omissos $\mathbf{e}$ as dúvidas que suscite a interComissão Directiva da Uniāo dos Escritores Angolanos.

8.: (transitório) 0 júri escolhido para a atribuição do prémio respeitante ao periodo refeitante ao periodo com preendido entre 1 de Dezembro de 1979 e 30 de Novembro de 1980.

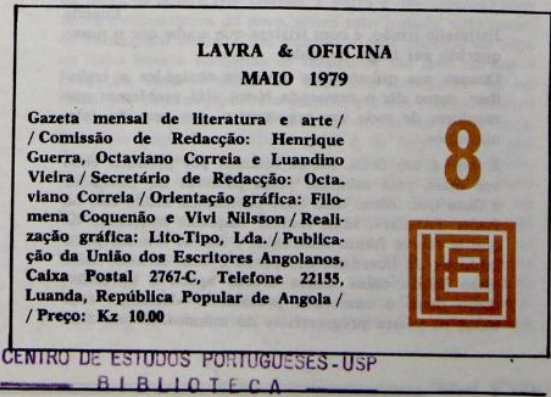

Aíquirido de:

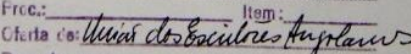

Permuta com: 13 o4 